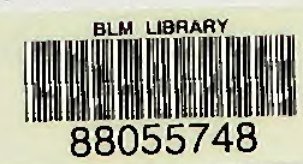

DISTRIT ADYSORS CONERENE

\author{
DNYSION OS GRAZING \\ F. B. CABRENTER, DJBECTOR
}

SALT LAKE CIIY, UTAH

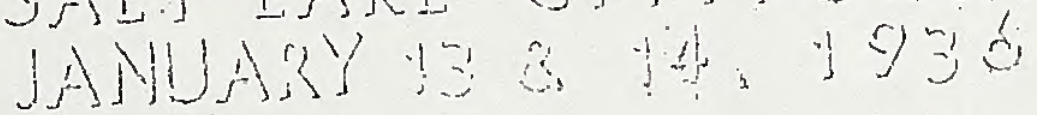


INDEX

FIRST DAY - Moming Sossion:

Addross of Wolcomo by Govemor Henry H. Blood of Utah................ I I

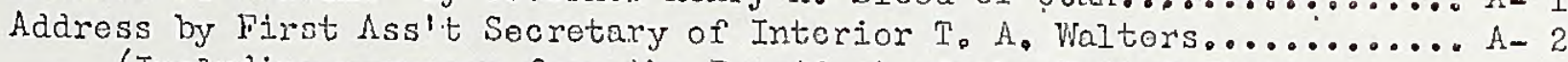

(Including nessages from the President ef the United States

and tho Sccretary of tho Interior.)

Announccment of Order of Business by Director F. R. Carpentior.........A-7

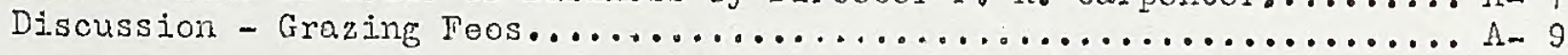

\section{FIRST DAY - Afternoon Sossion}

Address by $\Lambda$ ssistant Secretary 0 scar Chapman. ................... $1-19$ Greoting from Senator Elbert D. Thom of Utah (Read by Hir. Carpenter)... $\Lambda-20$ Wnssage from Congressman Bavard T. Taylor (Read by Mr. Carpentor.)..... 1.20 DISCUSSION:

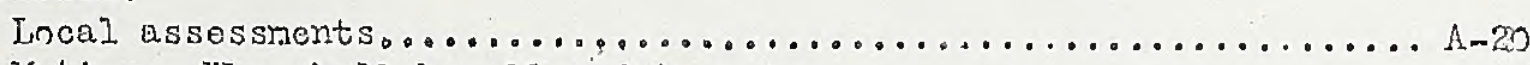

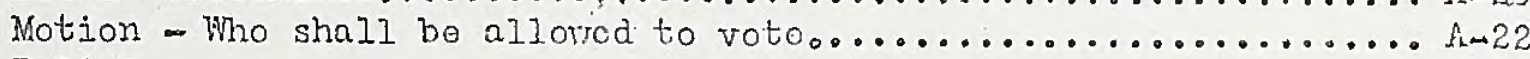
Policies:

1. Chango in ordor of proferential classes for licenses.... $\Lambda-23$

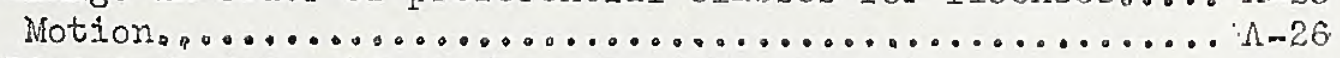

2. Division of depondont proparty into classes............. $A-28$

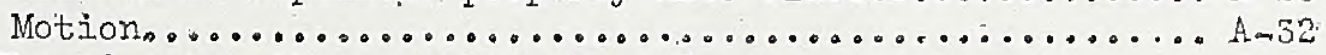

3. Should outs rithin a class be rade on numbors or by restriction of ssason of usc..........36

4. Should tomporary allocations of rangc be incomporated in 1936 licensos................. $1-3$

5. Should comonsurato property be divided into classes and dofinitely defined........... $\Lambda$ - 2

\section{SECOND DAY - Morning SOSSion}

Talk by Mr。 Julian Territt, Assistant Diroctor of Grazing............ B I Reanmendations of Stato Comrilttoos, folloring caucus:

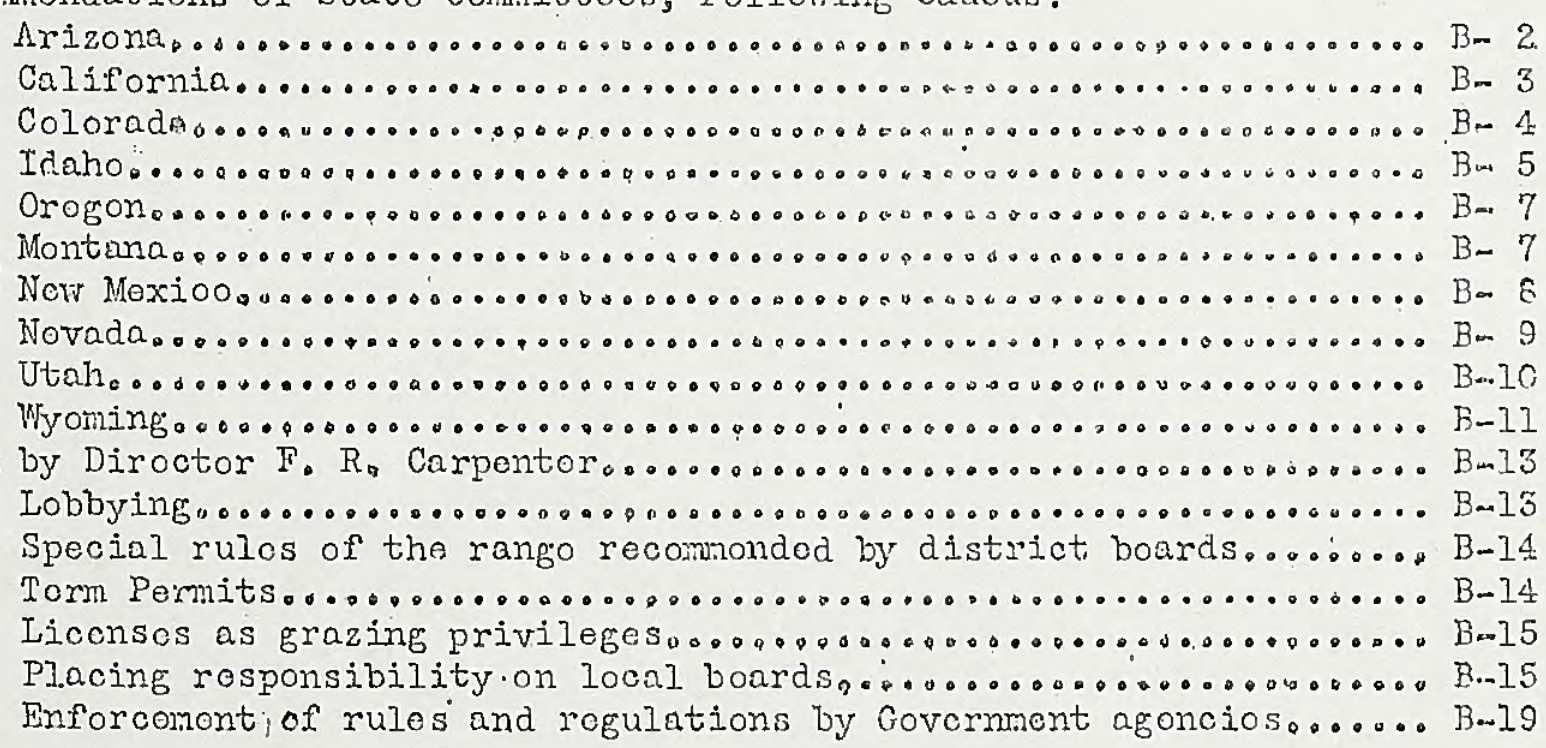

SECOND DRY - Nitornoon Sossion,

Talegram from soorotary of Intorior regarding Assossments...............

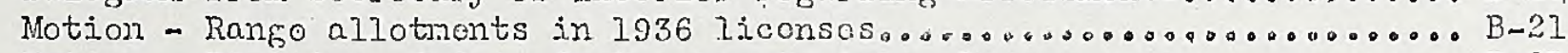

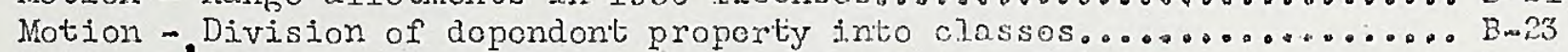
Motion and Discussion - Dofining connonsurate property.............. B -23 Motion (rodraft) and Discussion - Rango allotnonts in 1936 liconsos.... B-26 Motion (rodraft) and. Discussion - Division af Depozdont Propertyr

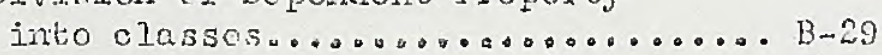

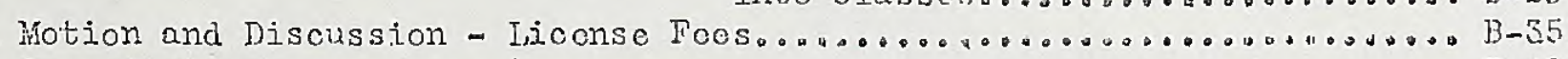

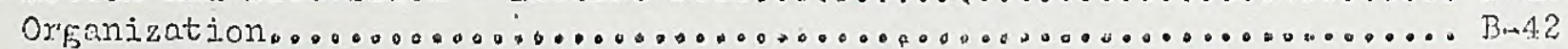

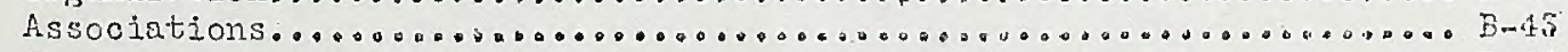

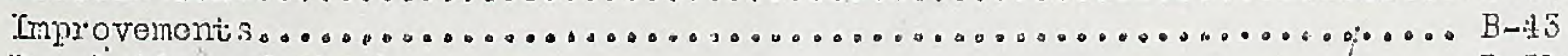

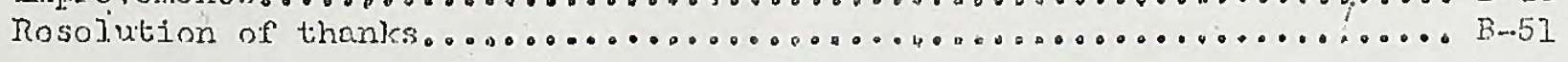




\title{
PIRS' DNY
}

\author{
Mornirig Stssion
}

(Meeting called to order ot 10:0C A.M., January 13, 1936, in the Iaf'arette Ballroom, Hotel Utah, Salt Lake City, Utah).

RADIO ANIOUNCFiR: Neurly 1,000 stockmen from ten Western states have assembled this norning th Salt Lake City's Hotel Utak to confer with $T$. R. Carpenter, Director of Grazirg, ard other replesentatives ci the Department of the Interior on the admitistration of the payjur $1 \mathrm{ct}$, providing for the proper use of the public domain by Eraziers of ljvestock. Lissistar.t Secretary of the Interior T. A. Walters nas come to the metin as the representative of Secretary Harold L. Ickes, ninging messaees from both the Secretary and President Roosevel.t. Governur Henry H. Blood of Utali opens the conference hy briefly welcoming the delegates.

GOVTRNOR HENRY H. BLOOD OF UTAY; Mr. Chairman, Ifr. Valters and other representatives of the Departsient of the Interior, and livestuck-men: It gives me real pleasurs to we..come you hore on behalf of the strte of utah, and to assure you of our desire that your stay will be as pleasant as we know it will be profitable. The state is glad to hes host to a gathering of this kind.

The last decade of adverse climatic conitions served as a timely warning that the day of unrestricted use of public lanis for prazine purposes vas at an end. Something had to be done. And that sometlifig had to be done now.

Utah was the original. supporter of a movement for proper regulation by the Federal Goverment of the public Jorkin. The Taydor Grazing $A$ ct and the rules and regulations based upon it constitute tine xnchinery set up to accomplish this purpose. Wo are al]. of one mird in the hope that a successiul climination of our plans and wishes wil]. be realized. luch depenois upon you gentlemen who represent the major interestis ariecued. We kros and appreciate the single-heartedness of purpose of the Federai aiministrators of this law. But, Eentjemen, they are relying upon you to assjst in working out ways to accomplisti the ereatest good to the ereatest number. The efforts ol all concerned should be unselfish. I feol. sure that you wi.l. approach this problcm, which affects the Vest for all time to come, in a broad and just spirit.

Many times the thought has been expressed that there are only two major interests directly affected by the proprari of edraintivation of the public

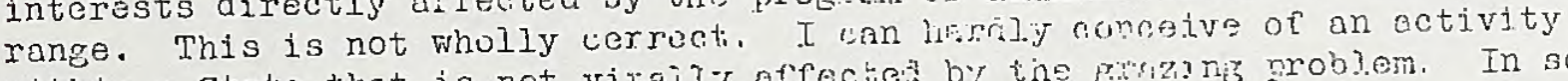
vithin a state that is not viraij. affectes by the errizne nroblem. In so far as a proprietary intorest in the lana is cruccmed, thise croups are involved. Pirst, the ovrer, of the foe Lends; seind, the lmited states which is in a position of trustes; third, wach individus thte, which, so in tha case of the individual, owns the land in foe sirnis titile.

The Department of the Interior is the delesoter "ederal. suthority to administer the public domain. You members of advisory bosrds are crpectod to aid with your knovledge, ripened by your meny years ox experience in tho Iivestock industry. 
administering the State lands for the purpose of raising funds for the support of the institutions for which the lands vere granted to the Statie by the Federal Government.

The third ownership, representing individual holaings which heve been acquired in various vays, is also seriously concerned itith the problem of administration of what has formerly been its public pasture grounds. Spenking for Utah alone this thira interest is abnormally gront beceluse of the commity ilie which is typical of rursl districts in this state. The interests of the residents of these small toins and hamlets are worthy of coreful consideration.

As you know, stiate land holdings are scattered in many thousands of individual tracts. Since the enretment of the Taylor Grazing legislation, the land departments of all of the lestern statos hove been endervoring to rork out in a cooperative vay a solution of what is samittediy a perplexing problem. As I unäerstand it, their unanimous opinion is that these State lands should be grouped into compact bodies. This is a question which must be decided between the States and the rederal Goveriment. It should be possible to bring about a consistent and sitisfactory settlement of the issue.

Mey I say in conclusion that it interested me grintly to learn that my orn State has 6,500 of the 15,000 licenseas in the t,en Western State districts? This state is, therefore, not only the geosraphical center of the public domain, but is also economically its core.

Mr. Walters, I wish to welcome you in a personal way as representative in this large gathering of the President of the United States, who sirined the Taylor Grazing Act, and of Secretary Harold L. Ickes, of the Department of the Interior, tho has initiated its administration. I also velcome other representatives of your Department.

Permit me to vish this conferme eviry success in its deliberations.

MR. CARPENTER: Thank you Governor Blood. It tras the orieinal intention of Sucretary of the Interior Ickes, iho hes taken a keen personal interest in every step of the administration of the Ts,ylor Act, to appoar in purson. before this conference. Press of business, hovever, mede it impossiblo for him to attend. In his stead he has sent Mr. T. A. lilters, Pirst fssistant Secretary of the Interjor, who has a messuge from his chief ns voll as the greetings of President Roosevelt to this conierence.

Secretary Walters is knonn personally to many of the delegates from Idaho. others knom him because of his leadership in civic and pliblic affairs and throueh his york as chairman of that State's Bonrd of fuducstion. I. take pleasure in presenting First Assistant Secrotary Welters.

MR. WAITERS: Mr. Chrirmm, Governor Bloor, Ledies and Gentlemen: It is not only a pleasure but a privilege for me to meat with you this morning, and I am delighted that so many of you are present. I hrve the distinct and distinguished honor or presenting to you this mocring, throush the secretary of the Interior, a message from our sreat President Franklin D. Rooseveit. (applause)

"The White Houso, Jnnuary 3,1936 . The Honoruble, The Secretary of the Interior. My dear Mr. Socretary: On the occasion of the forthcoming Salt Lake City grazing conference, I. desire to offer my congratulations.

"The grazing program on the pubilic domain under the Tnylor Griaing Act is a ner conservation movement that-pronises to hrve historic signiricance. It is the first time since, the settlement of the liest thnt there is an opportunity to regulate over-grazing on the public domain. In loss than fifteen months ufter the lan ras enscted the cattle and sheep men hrvo buried their differences and combined in a joint effort to abolish unfair range practices and to conserve natural. rtisourcss. The nost noterorthy feature of the prosram, however, is the unique cocsitination of locel and Fedemal offort wheroby fifteen thousand stockmen heve participhted successfully in the policy of the Depretment of the Jnterior to Give local nutonomy in the edministration of the neil lav. 
My great immodiate chicf, Socretary of the Interior, has also sont a spocial message deted January 6 , Department of tho Interior.

"To the Mombers of the District hdvisory Bonras and othors attending the Snlt Lake Grazing Conference.

"It had been my hope and expectation to be with you on this important occasion, but demands upon my time have mado it impossible. Hovevor., I have designeted other officiels of the Departmont to be present, and they will bo propared to discuss with you all phasos of tho orazing program. I am taking this opportunity to extond to you my best rishos for a succossful meoting.

"Notable progross has hoen mado in currying out tho grezing proglam since the proliminary organization stage has been completed. In any nen undertaking of this kind many quostions of policy end procedure inevitably arise which must be determinod, with s proper considerition of the lnil and of the divorsified interests involved. This is ospocially true if such a stupendous cooperative plan of administration, as ve have decided upon, is to be established and maintained.

"Various rules and regulations hive beon promulgater for the development and use of the range and others axe boing compiled. All of theso are in the interest of orderly and simplified procodure. Tho assistance ciren to the Department of the Interior:by the duly olected members of the Advisory Boards has expedited the transaction of business and has mede possible a smootlmess of operation that otherise rould bo impossible.

"As I said at tho Denver Conference last year, the District Advisory Boards are expected to rork out and proposo an equitable esportionmont of available range privileges within each district. The Buards vill not have administrative functions. Proir functions thile advisory will be of the highest possible use to the Dopartment of the Interior and of great benorit to the grazing interests if they nre risely used. hlroady, as a rosult of the work of those Boards, epproximately 15,000 temporsmy licensos have been issuod during the prist fou months. I vant these Eorris to have and to exorcise all of the responsibilitios which thoy cun carry and which, within tho law, it is possible for them to curry.

"I am sure that everyone interestod in tho grazing lav unierstands that the administrative functions are conferrod in express torms upon the secretary of the Interior. Those administrative functions, I hivo no power to delegete to others. For the purpose of enlisting tho intorest and the active cooperation of the stoclanen of the Vest, I did suthorize the setting up of the Advisory Boards to act in the capncity which thair name implies. I vent these Boards to ozorcise all tho rights and assume nll the responsibilities consistent with a sound administration of the Taylor Grazing Act that they can exercise and assume under the lair. It vill be unaerstood, of courso, that no executive officor has any porror' to go boyond tho lar that limits and defines his authority.

"One of the principel purposes of the present conference is to aiscuss the question of grazing fees as provided by the liri. I :ilil refer again to a statement I made at the Denver conforance which I still bolieve to bo applicable. I quoto:

'The Interior Depnrtment' will have no querrel vith stockmon on that subject. You are filline to priy rensonable foos, and that is all $\pi 0$ will expoct. I believe that foes should be on $a$ sliding scalo vorying with the carning capicity of the lind as measured by the mirket value of the livestocl: grazod upon it. Fees should not be so loy fis to arouse the envy of those not entitlod to public range rights or as to subject tho pormittoos to a charge of recoiving a Government suhsidy.

The wholo quastion of foos, at the beginilnb, vill be oxperimental. We vill approach the mriter with un open mind and consider it from the stendpoint aliko ot the public interest and of the relfare of the stockmen.' 
it-4

Since the Denvor meeting we have gone rar torard placing the grazing program on a sound basis, and I sm sure that the report of progress which Director Carpenter and others will make to you sill moet with your unqualified approvdl.

"Sincerely yours,

"Harold L. Ickes,

"Secretiry of the Interior"

Friends or tho Fest: It is altogcthor fittine and proper that President Roosevelt should have signelly honored this meeting with the congratulotory messnge which I have had tho pleasire to deliver to you, for this is indeed an historic occasion. This convention is 2 mile-store on the road of fmerican conservation, no longer a narrow path beaten through the iliemess by the doged determinition of the Departmant of tho Interior, but $\&$ brond vell-planned highray, built through understanding and cooperation, and leading literally to greener postures.

It is an occasion becnuse this meting is the first of itis kind in tlie history of the industry. It is a pionecir fitherine of the representiatives of viestern stockmen benti on estrblishing $r$ new frontior, - and I use; the tern "frontier" in its fullest meanine, - "un' sdvnncsi l'egion of settlement and civilization". We heve advanced uncer the Thylor Grazing Act to the settlement of important economic problems as $7 e l l$ as udministritive questions. We are, therefore, establishing a nei frontier for the stock industry of the vest. We hope to perpetuate all the spirit and romnco of the old West and veave it into a sustained and regulated industry of the futuro.

The romance, of the West has not vanished like the maters of a dry river. It has merely chenged to less speotacular but certainly to no less thrilling courses. You have but to substitute "the snving of. the Vest" for the empiro builders bettle cry "the rinning of the "fest" to realize the full import of the present undertaking. Stockmon "ill no longor hnvo to win and hold range lands in the Hest against human maraucer, but they will have to battle the forces of nature to save the rolling renge from srosion and from the unrestricted competition learing to devastating over-grazing.

This first cinnual mesting of the fruzing listrict arvisors, - and I am proua to stress the word "onrual", - is unidue in our anmals as it initiates a yearly bathering of those dericcted to the policy of a prudent use of "public grazing "lands for the benefit of' the livestock inlustry. Io are gatheren together because the emministration of the Taylor Grazing Lar, unier the rules and regulations set up under the Depuruent of the Interior, culls for your advice and recommendations. It ill be Iscalien that secretary Ickes, speaking to the stockmen of the West at Denver, Cojorndo, eleven montha ago, said, "a patriotic regard for the highest interest of the National vilj. impel you, I am sure, to work hand in hane :ith your Govesment iu miking this epochal Act the means of a Netionil. contribution to the prosperity unc contentment of the whole people". It ris in thet sarne speech that he predicted that the election ind use of alvisory bonris of stoclimen in every grazing district on the public lands would riay in import:int snit vital part in the district on the public lat. 'Tho presience buretosy of more thrin 130 delesates from the 34 grazine districts now operatine in 10 states of the West is proof, positive, of the fulfiliment of the secretary's prediction.

Few laws administered by the Netifonil Govornment so vitally affect tine economic nelfare, the industrinl activities, and even the stancard of living of the Nation as does the Taylor Grazing Act. Through it ve seek to conserve one of our great national rosources, - the remainirg public lnnds of the Wust. By conservation we mean not only to loja for future use tho remaining broad acres of the Vestern States, but also to overcome erosion snd its evil effects on the vater supply in a land where water is lire, not only for agricultural. purposes but for the benefit of urban ponulations which more than ever vill depend on tho streams an? rivers which trke their rise on the public domain.

- The President pointer out in his message to you "as the most notoworthy feature of the program **** the unique coorcinction of local and Teieral agencies thoreby 15,000 stockmen have particifyter succossfully in the policy " 
of the Department of the Interior to give local autonomy in the administration of the nev lav". Certainly no one is better quelified to advise and recommend in the adninistration of the Taylor Grazing fict than you delegates from the 34 Grazing districts. This Act, like the majority of laws onacteg by Congress, ras postulatod and grew out of the actual experience of the industry which it is designed to perpetuate. Its administration is being developel on that snme pincipal and your presence here today shows how successfully this is being ac complished.

The Department of the Interior, chargeil by lan with the administration of the Act, has had, and has nor, absolutely no intention of setting up a bureaucratic, despotic organization to cerry out the purposes of the fact. The Departmont earnestly prefers to take uivantage of your victe knowlenge lof local and general conditions and to use your survices to develop a cooperative, movement for your benefit and for the bentit of the Mntion.

The attiture of the Department is well illustrated by the history of its effort to put the ict into operation. It will be recalled thet almost immediately following the signirg of the het hy the Fresident, a party from the Department, headed by Assistant Socletary Osari. L. Chrpmen, came to the West for the purpose of contacting the stocknon snd lairning their wishes and profiting by the experience of the citizens of that nortion of the country in which the Act is of parmount importance. This ws followed by a series of State moetings where the stocknen themselves suggestad the boundaries and size of the brazing districts. Then, aiter a poriod of stuly, of drafting regulations, and of coordination of infomation in thashington, the rules for the apportioment of the ranges and for the distribution of licenses vere brought West and submitted to you for criticism and alvices beiore being finally approved by the secretary . Plections of grazinc district acivisors in each of the 34 districts follone. With the fomation of advisory boards, recomendations on tho applications for grezing licerses and for the establishment of rules for fuir rango prictice follow? quiclily. This proceduro is rew and

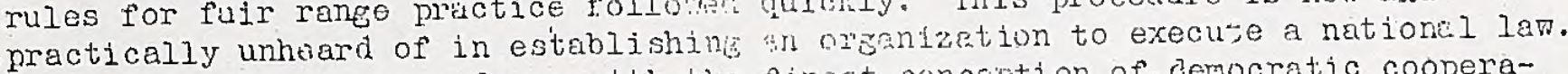
It is, however, in accordance with the finest conception of cemocratic cooperation: and government by the consent of the governed.

Muy we summarize some of the accomplishments since the estiblis hmont of the first grazing district. There ere now s4 iluly organized and operating districts. The elected representatives of the industry in those 34 districts advise and assist in the administration of proctically $80,000,000$ acres of public grazing land in 10 Wostern states. In round numbers, 15,000 erazing licenses have been issuel for $8,000,000$ head of cattlo, sheep, horsos and ëoats. This, in itself, is an achievement in so short a space of time. Tisoso licenses reveal sicnificnint and relevant facts. They are, that of all of the cattle licenses issued $94 \%$ are for less than 500 hear, ond of all the sheep licenses issued $87 \%$ are for less than, 3,000 sheep. In other words, it is cipparent that the puylor Grazing Act is allesdy functioning to nn amaine and cratifyinc degree in protecting und encouracing the little min. This is a consumration much to be desirea. Herdsmen with small flock, the farmer with a small., " number of sheep or cattle is as much entitleil to the use of the jublic domain as is the large operator. The operation of the fet hes kilrealy in 8 large modsure done two thines long hopel for, thit is, the burial of the differences betreen the cattle and sheep mun, and the estiblishment of peace between the big operator and the little fellow.

These results have been brought about under the rules and regulations set up by the. Interior. Dopartment which, inciuentally, exploys only 37 rull time people in the Division of Grazing. The Departmont, horgver, has had the advice of 509 district bourd advisors who zire fintiar with locil problems and conditions. In the election of the District jivisory Boarts the principlo of "One mun - one vote" was put into practice end it isas a perfectly nutural result that the 94 and 87 percent of the "Jitt.e ma" reccived a fair und proportionate representation on all of the aivisory bonrls.

The way in which the District frivisom Bo:alda here assisted in this rork has been most gratifyine;. You have urlojted " vitily non-pertisan attiture and oarnestly sought to provito the rital basic infoys tion concerning range 
$\Lambda-6^{-1}$

operations in your respoctive localities. You are to he complinenter? on your willingness to sccept the many responsioilities in recomnending end advising on the solution of the. difficult problems which have arisen and will arise. The Departmont has faith in you and in this cooperative system of aciministration.

The success of our effort is primerily one of conservation and restorstion. In many places on our public londs iorage resources hove practically disappeared. Development of the inclustry depends upon the improvement of rane contitions. Unier the leakership of President Roosevelt, conservation of our national resources hats become a recility, an:? new mediurs of conservation heve been created. One of these is the. Civilian conservation coms. We hive available throush the CCC menns whereby range improvenents which would otherwise take years to accomplish may be male in a comperatively short time. Before the enactment of the Taylor Graizin lact it ras not thought advisable to make ranfe improvements becalise there was no adequatic protection for them when they wore completed. The Grazing ict nor provides this protection and the Department intends to further the CCC mogrim of inproverients to the fullest possible extent.

There are now 43 CCC crmps in opertution on various portions of the public domain, chiefly in the southern areas where they are nor engaged in important work. During the coming season we howe; and expect, to betin sirnilar work in hifhcr and more northern regions. There has been more than a little epprehension among you concerning possible clurtailment of our CCC prosram. I can assure you now that there will be no cut at this time. Moreover, we are making strenuous :efforts to obtain additional camps throuth which this program can be spread to all areas of the public domin.

The law specifies that pormits shall not he issued until the land has been classified. The Division of Gruzing hes alrenty bncun this work which includes classification studies of ranges and of commensumte properties so that these leases cen be related to the Innd and wites omned, ocunied, or leased by stockmen within or near gruzing districts. In chror to exifite the work of classification, an arditiont. force of qualified rance mon rill soon he employed. The President his recommended to the Congress an incrense in appropriations for this clessification work.

Under existing rules and regulations and Executive Orders, Sections 8, 14 and 15 of the Taylor Grazine Act are now operating. Regulations for the leasing of landunder Section 15 have been kpwovol and are here for distribution. This section provides for the Jensing of isulkted tracts of land to contiguous land owners for erizing purposes. Insmincin as these lands are to be leased in blocks "of 640 acres or moro' to orners oi ajacent land, may i point out that with the issuance of these finil remlations the first move in the leasing of these lands must come from nei hborine land omers. Since the preliminary regulations for leasin these lands weje formulated on september 27 , 1934, there hove keen received 3,200 applications for leases. Each lease will be handled separately and the terms of the lease rill derend on the local conditions.

Section 14 authorizes the Secretary of the Interior, in his discretion, to order the sale of isolated tracts of the mplic domein which do not excesd 760 acres. It also erants to contiguous land oiners a preference right to buy the offered lands at the highest bid price, not exceeding three times the appraised value.

Section 8 of the law authorizes exchanges in the irblic interest of State and privatoly ormed lands of equal value for public lunis. Regulntions for the operation of this Section were issued on Pebruary 8, 1935. They vere amende? on November 2cth so that no fees are required on oxchanes involvine State-owned lands. It may interest you to know that so fir there havo boen filed 235 applicrtions for exchaness of State-ovmed lends ard in apilications involving land in private owership. We are workine on arrnisements rihteh will make it unnecessary to refer to the Division of Grazing all applications involving lands so situated as not to justify their inclusion in srazing districts, and thus expelite action under those three sections of the Taylor Grezinis Lriv. 
Ve are now faced with the lurger and more difficult problen of establishing equitable and reasonable fees. It must be sssume? that benefits which will accrue under the Grazing lict cannot bo obtainod rholly without cost to the livestock inaustry. The nct conteriplates and imposes upon the Depurtment of the Interior the duty of fixinij a charge to be jinid in the form of grazing fees. of these fees, $50 \%$ of the monoy. collected is returnable to the states for local purposes and $25 \%$ is, upon uppropriation by Congross, to be used for the improvement of the range.

It might he wcll to benish the ghosts of a fer rumors which heve baen wandering in melancholy fashion around the Vost. The, Department of the Interior has not now, and nevor had, any intention of adopting a scale of hieh fees. One of the purposes of this meeting is to 7ork out a foe which will be reasonable and satisfactory to the industry:

Representatives of the stock incustry have sugester that 5 nominal fruzing fee be establishec durine the license porior vihich would be less than that; charged when pormits are issued. A permit is un ssiset, different in charaster from a license and rould justify a largor fee. It has boen sugrestea thet' a tomporary fee of five cents rer-hoad-per-month ior cattle snd one cent per-hear-per-month for sheep be estriblished. I was very clarl to have these sugfestions come from stockmen and they sem to me to be rensonab:.o and. practical. This will prevent any discrimination botioen those us in the year-round rance and part-year rangc. It rill ilso prevent discrimination between those usinE ranges of varying quality, which would arise under an acreace basis. On a head-per-month basis, those usinf a scant ranere will pey no more por month por animel than those using a well covered range. The suggestion of the five cents per-herd-jer-month fee for cattle and a one cent per-head-per-month fee for sheep will, in my opinion, have the favorable consideration of the Department. By setting up a nominel fee, vie vill bain some. time to settle cortain problems before us and to attack problems wich will arise in the adjustment of the permenent fee. Unier the adopted practice and proccdure any subeestion as to fees is subject to the approval of the Department.

Thile our great President, Franklin D. Ronsevelt, and my dynamic, and officient superior, Secrotury Ickes, are true conservationists, they are also practical men. Your problems are real to them and receive rationil and sympathetic consideration. I feel that coordinated, democratic, and understanding. adninistration of the Taylor Grazine lict will meet the problems of tho present and mensure up to the possibilitios of tho f'uture.

I thank you.

IMR. ChRPISNTER: Thank you secretary Wa.lters. Gentlemon we are roaky for business, and in order that you may understand the mothor that we will uso, I will say that we expect to conduct this conference in a rather aifferent vay than whet many conventions you may havo attendea hivve been handlea. Te have torked together hefore but largely in separate States.

We are now Gathered, the 10 States by delegates, here togcther. It is necessriry, therefore, for us to cet the nationul objective of the act clearly in mind and do all that can be done in tiro arys to get closer to that objective. I will state briefly, in order that vo my never have absent from our minds, what I conceive to be that objective, and that is the proper use of the lands not only of the public lands but comnonsurite jroperty so situated around and scattered through this public domain, that in order to have any value to mon they must be hooked up with rango rights.

The second objective, which will follow naturilly when the first is attained, is to stabilizo this business, which means a livine, to all of us. Non we have been engaged in tho lust 17 months in stejs ajpronchini that objective. It seoms proper at this time thet ne should take a little scenunt of . stock una sec what we have done, but more than that wo went to take furthor steris in the same diroction nrovided we hive been headed right. In order to set thore it would geen that the policy of discussion noulr? be more fitting for this assembly than a mattor of papers and speeches, and for that resson there vil he no more formal. papers or syeoches made at this convention until the list sifternoon of the lant day, whon the last two topics will be takon up lriefly by speakers with. fivo minutes allotten to them. 
$A-B_{0}$

The entiro business of the convention rill be divided under four hetids. The subjects of finances and pojicies vilil consurie today and half of tomorrow, and the last two subjects are organization end improvemonts. The first toric is the topic of finances and in discussins. it, after the yroblem is stisted, we will call for ilscussion from the floor end various points of view. Inmentately after the noon hour you bill bo esked, in order tlet re chn bet our mechinery into action, to meet by states and moet under the bannor for your state in this room and olect o temjoriry State chairman who, whon that State is callerl upon to give tho point of vier, rill have a snokesmon. We till then be ready for business agiin at 2:00 p'ciock. Wo will then talce up the mattier, if we hevo not finished it, of rinunces and start in with the matter of policios, which will take the rest of the day and tomorrow mornine.

Tor those primarily interosted in the sile, lense, end exchane of land, as issistant socretery Valters has töld you, there will be st seprrate meeting at 2:30 thjs aftornoon on the roof iram whe the risistant serretany and

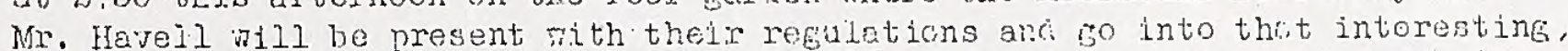
subjoct, and you are all invited to nttend thet meeting on the roof garden! and wo will so chead with the prinary grazing work hero in this room at the." same time.

I heve not boon lyying to wurk on as sylt minute, but I fieured we vould reach this polnt at elovon $0^{7}$ clock and it is nor foll minutes to, no I vill tell you vo are runninio rieht on schedirle.

The first order of business is to take ur the subject of finunces before wo aprrosch the matter of fees. It is well bo know rhat the bude, of the Division of Grazins incluies, and for your conveniones that is set forth in the prosram paper on the third pase, which you heve in yous hands. I will do no more than run over it, and then if there is a quastion or two, answer it. Then we nill take up the matter of fees.

The rederal fiscal year runs from july lat to mly lst, and the fiscal year thrit mo ore nov in the socond half of, ihich in offinial parlance is donominatea

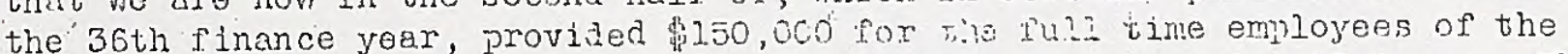
Division of Grizing and exponses an? mis transforred from the Geolouical Survey 68,00 ? mero. To have not nearly used up that apportionment, neither hes tho fril tice Division of Grezine used their half, nor hnve the district advisors used thetr half, and you muy smile and think when you are through maye you rill. ore the Felleral Government something for working. But I rish to sssure you that this was a ner method of payins district advisors, and the nocessary tupe to unvind is being unroind. You may all be assured that you vill get your pay, "rid if you don't you may be assured your heirs and assigns will.

Non, eentlemen, next year the budeet, es sprinowed by the ispropristions conmittes of confress vith whom I met a few wets pso, calls for a total of 412,000 : For the full time employees 312,000 ; for district advisirs 100,000 .

The increaso in the full time Division is due to the necessity for the ran examination which re are soing to uncertske tinis yeer in order to mike the necessary rance allocations and allotmonts, end rarticularly to get the land reacy for term pormits $\nabla$ hich is the f'irsti wreut, and permenenti step for the protection of land and the stabilizetion of livestock values, and of course, for the conservation and development of whit grors on it.

Nre there any questions on this budget?

If not, I vish to suy the relation of the burget to the foe ma or may not be desired by the stockmen to he considerea. You will recollect that the me, lor Act siys that 50\% of ald the fees shall go to tho states for the use of the counties. Now it is not denominated what the counties may lxe it foor. The countios hel; take care of the oor -.. or they used to. They have quite a bit to do with the rocis. They have thoir county revenue funds for the pay of county officers unf incidental exponsos slso under the county comes a jeneral school tax. In my om stste, Colorsdo, the lorislature has said that $50 \%$ of the maylor fees shall no from the Fcileral. Treasury to the State Treasury to the county trensury ond into the seneral school tax. If the state lesislntures ad nut act, it rill so into the cereral fund, whorover the county comissicners vish to put it. 
In the State of Oregon and the state of Nevode the legislatures have mot and said thet the Stute Preasury and the county trensury sinall he is conduit for $50 \%$ or the fee which shall theroupon be paid over to the listrict dedvisors for the betteiment of the district, so that thore uro four nossibilitios ior every dollgi you "re going to jay, that it eoes in'o the kaneral county Imi, general school fund or for the betterment of the listrict, as your lealsinture mey provide, but in iny event it c;oes fior home purposes. Trenty-five precont of the fces will co for the betterment of 'the district to' be expended whe Denartrent under our present set-lul. This tiro-hits on the dollar has bisn rather ovex-shaciored by the emerency proiram which hes boen going or in CCC camp. But ss ge bu on and believe we are clinbinis nut of this depression we see less aild lass reason for this emergency mensure, congross inaicat; every cenire to turn back this two-bits epprojriation which is soing to bo w imanso value in cevelojing and protectine these grazing aistrictis. 'If it conce be experder to incluse the lands not in the public don in wititn the cisisictis, think of the nossibilities. You would then havo a full. use not cnly of grazin astats mich could ba

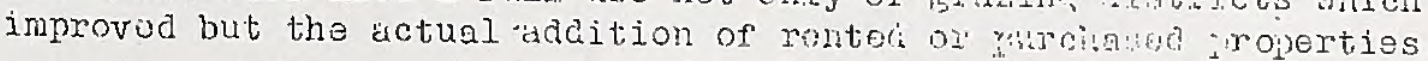

Whet becmes of the cthor $25 \%$ of the money, wis ict does not stete, buit it

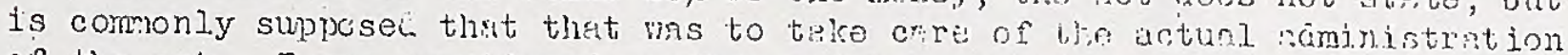
of the act. I was questioned on thet joint hy tre mrorintions contititee. I told them that as to fees the stcclaen had besn asurat that no foo would be set until. they had a full. time to lisciss it, but that it rris cenerally mpjoser in

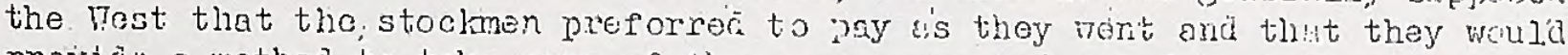
provide a method to teke care of these expenses and jet $10: \mathrm{n}$ to businesis busis as soon as possible. That my or moy not be alvisusle titi this timo. There may not be value enough received in these tempory licenses to taic caro of it. Rut if it is tho wishos of the stockmen to go on to $a$ busiross anc myju basis, it wili be neceasary to adjus fees on a 4. to l basj. s, inity cents to so to tho local Eovernments, or as indicated tiro-bits to 30 for improvement and the other tro-bits to take care of the apiropintjon: One kdvintage bs tilat it makes every one of the 15,000 users of the puolic domain watch the orpenses. You know the Eeneral tendency of all crusinment expensss. The inevitabie tondoncy when not ratched, and oven when watchea, they heve a toncency to creop upwurd. So we immediately jet the frolin; that; the mors varkbis these unitr; ere held, and the lomer the exponses are kept, tho better ofr ; $I l$ to the stockmen as risicis fees.

I will diviuje the topic of crazine fees into two liesds: First, should

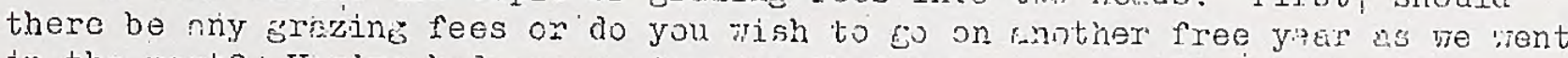
in the past? 'Huine had expressions on that mater, we rill take up the question, end it will be roferred to the comititees to reprirt beck hele, as to hor much that fee should be. Now I nur geins to ask ispeakers when they bet up if they ijll please rive thuir rame ark state in orlor that the rajorters may Eet into the rocorr? what wos snid here, and I vill: nek for expressions of oninion as to wither, rith your rnowlodice, particular. district, you believo it is coins to he advisable to hive nuy foes, or whethor

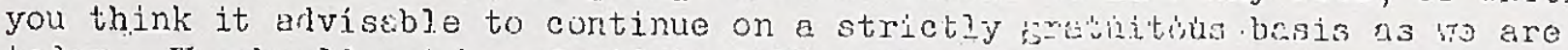

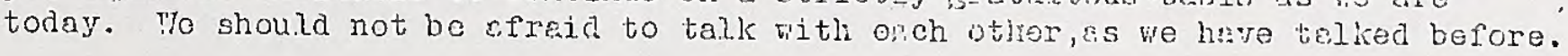

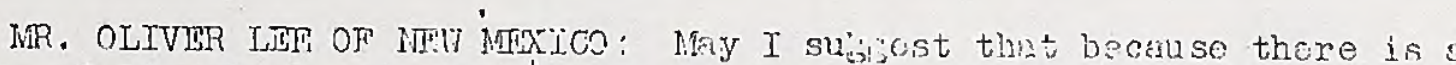
number of livestock raisers present in this moting that are not on the advisory boaris that they be askei, onpecinlly to discujs this question at this timo. I feol that the members of the acvisory bosrls srould hesitate nt this time until. they are permitton to caucus nac doternine ss a bcdy just what their position should bo.

INR. CARPEITER: Mr. Oliver Loo has taken the juition that the duvi sory hoards rould like to hear from those not on the chvisory boares before thoy go into thejr caucus. Is that correct?

MTR. LED: Correct.

IIR. FRCCK OF WYONIN: Inesmuch as the credit of the stuclamon is vital at

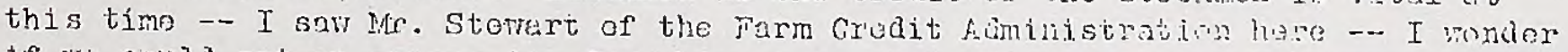
If ro could eot an oxpression from him as to wht offert iemporiry lisenses rould huvo is kajansti permits in tho credit flicilities of" tho Govermont. I think thst mient be quite a ractor in ansmoring; the question ;hich you askes hero brfore.

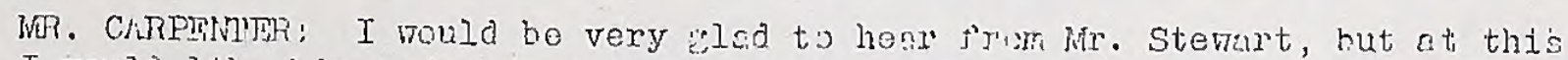
time I fould liko him to tiko up the question os te mhothor any ree is alvisahlo 
$A-1 C$

MR. BROCK OF FOMING: My thought is fust what effeet he would consider temporary licenses in making loans. That would hrve some effect on the other question.

MR. ChPPELITIR: We are not disoussing wluether ro pill have temporary licenses or not, but whether we vill have a fee for them. Would you liko to hear frum Mr. Sticwart on that, Mr. Bruck? We are poine to reach the riatter of temporery licenses or permits a little liater on in the prosem.

MR. WING OF C'LITORNIis: Nr. Chaiman, the stoclomen frum Novada and Cilifornia who ere temporary licensee's unier the Thylor Grazine Act; have not caucused in reference to the following, but have mae these sugestions. They offer them for your considerition, and elthough winen they do caucus they may chance their present stand on these matters.

The Iicensees under the Taylor Grazine nct of California Districts No: I and No. 2; Nevada $35 \%$ I and 2 , are not in $\varepsilon_{\text {i }}$ losition to pry fees for crazine at. this time, unless:

1. In consultation with ereati kencies they wil. ngree to allow the increased umount necossery in the stockmen's buçets. In this connection it will necessitate consultation with indivicual stocknen and creilt agencies affectea.

2. The livestock men tho áre licensees of Culiformia No. 1 and 2 , Nevade No. 1 and 2 , today are paying their full share and are lnrely supporting school, county and state taxes.

The valuation of the deeder land of these stocknen gives full considoration to the public lomitin which said deerted land controls.

With locil, State and Tederol taxes increasing and rith these deeded lands and personal. property alrendy payine an undue share of the trix burden for the support of schools, local. State and Feciertil Govornients edditional costs of livestock production at this timo is unvarnited and will rork in uncue hardship on the livestock industry.

3. Iny business in omplnyment of labor does not pay crsh in advance for labor to he done. In other words, if additional. henefits to the livestock. industry are to accrue through the operation of the Taylor 'Grozine' kct, such benefits should be paid for after it hes been remonstrated that suin benefits actual. Iy do exist. The lond was classifiea durini; the year of 19.35; the protection of the individual stocknen's ranje from trespass thus assuring the stockman of range jrotection and the actual makin̈ possible of edditional feed has not yet materinlized.

4. At the present time range rights have not heen established. Feder:l loan acjencies torlay will not accept a license to cirtize on the jublic comain (Taylor Grazins Districts) as colicteral. If sati I'ederal loan agencies aro not willine to acceit a crazinit license is collater.l, it is clearly demonstrated that no additionel bonelit has been deriven by the stoclaman and that the stockman's license' is not secure.

Until the determination of ranse richts, ind the issunnce of long term permits (Iicenses) to erize, the stockmen are not in r position to pay additional costs of handint livestock on the trazin $n_{i}$ districts.

5. The vater which makes possible the grazing of livestock on the erraing districts is $99 \%$ owne? by the livestock men. The stockmen have reveloned said water and invested heavily to meke this water available. The feod rithout the water is valueless. The stockmen have paid out in the devolioning of the water - all the feel is vorth.

It also should be consiclered in this comection that the wild life inhebitine these erazinis aroes depenis upon this ruvetely ome? water. The stockmen do not charfe the Government in its jrotection of rild lifo for the use or this intor. The number of ceer, intelope cind other forms of wild lipo would be much less if it vere not for the rktêr develonment curried on by the stockmen. 
Therefore, we the delegates representing California Grazing Districts No. I and 2, and Nevada Grazing Districts No. 1 and 2, ask that no grazing rees be placed into offect for a period of fivo years commonoing with January $1,193 G$, and that at the expiration of said period if it oan then be shown that addjtional benefits havo accrued, that, thore is stability of range use; that Fodoral prodit agancjes reoognize. grazing. licenses as collateral; and if the stook-raising: industry has the ability to pay - that thon grazing feos be assessed on the basis of the total animal months and feed units which said livestock graze within said grazing districts in comparison with the animal and food units which said livestock graze in the national forests or on privately-owned Iand.

Further, that said grazing fees shall bo only the cost of administration of said grazing districts.

Whereas, the Taylor grazing act is ono of the constructive pieces, of legislation passed by the Now Deal for the purpose of the protection and. stabilization of tho livestock industry and the conservation of tho range, and

Wheroas, the livestock men of the public land states have made a tromendous offort to maintain their industry so that it will be an asset to the countios, Statos, and Nation and have only been ablo to do so with tho aid, of the Federal Govornment.

Therefore, we now earnostly request that during the period of setting up of grazing areas and in the dotermination of rights for use of the public lands in comection with private omership, prior use, that no foo be chargod for grazing privileges and,

Be it further resolved, with the full understanding of the stoclmen that grazing foos will beapprovod by thom whon they are in a financial position to bear this additional burdon.

MR. CARPENTER: Gentlemen, wo arc off to a good start. I thought/we yrero ooming to it inevitably -- that whon we woro through the roderal Govornment. would owe you something for runing on the range.

SENATOR CAUDLAND OF UTAH: Mr. Carponter, I sliould not objoct so much to. tho grazing feo. I don't object so much to the grazing foo if I trit some grass, but if I have, watering places on the range and pooplo who go on the winter rango before $I$ do and sweep all the reed axay from around my watering places $I$ don't think I should pay a grazing foo whor I dor't got any grass, and that to me is more important than tho question of the amourt of fee or when I begin to pay'it.

MR. LUBKEN OF CALIFORNIA: Stockmon: Wr. Wing here gave you a statomont as to the attitudo of California No. I. I will havo to havo it understood that I am from California I, from the Mojave soction, and I belicve I am tho only one hore from down there. The shoepmen did not come.

My instructions wore that wo should pay for this range, that it was worth it to us, and tho amount was 10 conts per hoad for cattilo and $2 \frac{1}{3}$ conts for sheep per month, or a dollar por year for cattlo the yoar round or, 25 conts for shoop.

I could not vory woll lot that statomont of Mr. Wing go by without making that statemont. I plodgod mysolf to tho committec back in Bakersficld that that is whore I would stand, as that was thoir sentiment and I would do all I could to put it through on a pay basis. Wo feol that wo should pay for what we got, and if wo got it wo aro going to pay for it . It is a great dcal liko tho Forost Sorvico in tho oarly days; when thoro was not any foo tho Eastorn ropresontativos thought wo woro: gotting a big thing and mado all the fuss thoy could. That is tho roason wo are winoro ve are today with tho Forcst. sorvico.

I beliovo it is worth 50 conts an acro on rented land liko wo havo to pay in our country, and wo can got bottor grazingland on tho public domain. I boliovo 10 conts is all 0 . K. I am giving you tho attitudo of my district. As to what tho balanco of you want to do is all 0 . K. vith mo.

IMR. NEILSON OF UTAF: "I think wo havo prosontod by those two gontlomon tho " two oxtrónos. 
MR. STAAS OF UTAH: In my district when we started to put in an assessment, and I have to tell you that when we have, the money in our treasury -- and, we got two riders - . we have got wonderful district and do protect overy man. In every disputo" we send our riders and settie, and after wo got orders from Interior Department broke dom the money, we, are entirely up aginet it.

My friend spoke about the work. That is the question. If we have got riders and can enforce the law and can get thein to rescect the law, that is going to be wonderful law. I wonder how we can contrel our district without any way to onforce the law, without any means to eriforce the law I am afraid every one hero - all of us - are going to be disappointed. If wo later increase the assessment we are going to have wonderfui. system, protect every man, especially the men who are liable to be orerpowered by some of the people. Therefore, I believe we are going to have to find somo way to finance the act, otherviso we aro moing to be disappointod.

MR. WHIINNERY OF COLORADO: Mr. Chairman: Spenking not as a representativa of the grazing force, but as a represontative of the man at home who is running this stock on the range, I jelieve Mr. Chairman thot the payment of the foe, whatever may be agread upon as just and right at this time, should be conditional upon the is suing of the permits.

(Applause).

MR. BACON OF IDAHO: I would like to indorse the statements made by Mr. Wing. I don't think our people in Idaho, vant to pay any fee untif we have permits issued. We have not anything in the way of rights that is of any. value whatever. We cannot borrow any money on it. Whon that perrit is issued I think Idaho would bo willing to pay a foe.

MR. MCPARLAIE OF UTAH: Gentlomen: Utah has been in this thing a long time. They perhaps have been in the froat because their necessity has compelled them to be. On account of the shortsago of rexgo, we folt the pinch earliar perhaps than any other state. Ard vilie I beliovs... in iact when I was in Washington I told them that the catislemen wore willing to pay for what they. got. But they want to get what they pay for ... that is what we have got to do now. I just want to say this, that if wo don't take hold of this thing and are wiling to pay for what we get, we arc not going to got thesc lands.

Wo have the Wild Life asking for ten or fjeteon million acres. We have the Park Service asking for fifteen or twenty miliion acres, and the Forest scrvice asking to put more in, and if wo don't takohold of this thing now and try to do something; you are going to find that we, will not havo these lands to graze. And I think it would be a mistake to try and put it off for five years, because we would have nothing to supervise and regulete.

I can't tell you what I think is right on the part of a fee. I think it should be a sliding scale, but let us be ri ght about it - cooperate, cattlomen and shecpmen work together and try and protect theso ranges and have something worth while. Thore is n' use thinking you have got something when you have not got it. So let's get startod and got this tining built up.

MR WEBB OF ARIZONA: Mr. Chaiman, Ladjos and Gontlemen: Two extromes have bcen suggested. Extremes aro rarely ever right or wise. I believe a happÿ medium is the best. Mr , Carponter. I believe in Arizona we have been lod to bolieve by talks of yours that undor the liccnso period there would probably be no fee. I think, that is only fair and proper. I still think it would be wise, until the whole, program has beor worked out and operating in all its details, that there should not bo a high feo. I should thirle there should be a roasonable amount. Thoro havo boen reasonable ones suggestied hero.

The State owns a large proportion of the land, and evóry cattlo and shoopman in the State - practioally evoryone has Stato land loksed more or less, and they cro paying net to excood 40 cents a head a yoar on very much bottcr grazing land - the bost of tho stato-boouse tho first homosteader or sottlor took thoir choioo of all the bost. Thon the state camo along and thcy havo sclocted all of the very best, and we are paying now not to cxooed 40 conts, and somatimes muoh less than 40 conts. The public domain lert is not nearly so dosirablo, and Mr. Carpontor, for your bonefit, thero aro soctions, 
many of thom in tho state of Arizona, thore the livostock ovmor should be paid to bo pomittod to koep thoir cows grazing on them.

'I think I saw a lot of land in the state of Utah that I would not lot a cow of mine grazo on. I boliovo in your sincerity and your dosiro to mako a succoss of this Taylor Bill oporation.: Wo boliovo it can bo dono.: ho aro extrcmely anxious that it should bo dono. One roason wo oro anxious that it should bo dono is that wo think if wo can mako a sucoess of this and show that tho dogroo of local self-govornmont that is given us undor this grazing distrint, that if passiblo it will havo an influenco in gotting us a part in tho rogulation on tho national forost.

Now I think a happy modium betweon theso two oxtromos is right. As soon as pormits aro issuod, wo should bo not only willine but anxious to pay a reesonablo foo; or whatovor feo tho industry can stenu.

MR. CECIL OF OREGON: I an from District 2 in Orogon. Whilo wo didn't have an opportunity to caucus moro than one of our procinats, it was tho opinion in precinct. ., District, 2 , that fivo oonts per monsh por cow and ono oent per hoad per month for shoop rould bo'

Some of the gontlomen have said the impartance of this whole thing is not so much tho anount of the foe. It is what wo get for our monoy whon we get furthor alcng. But wo ali roalizo, in ordor to get siartod, wo have got to pay a little as wo go, and whother tho ono cont ond five cents is exactly the right amount at this timo as a starting proposition - it ought not to wrock any of us, and I think it fair and roasonablo. it moots the approval of tho peoplo in: District No. 2 .

MR. HYATT OF WYOMING: Wyoming No. I fools while wo aro undor tomporary liconses wo should. not be chnigod for somothirg we aro not getting. Wo aro undor somothing like tho gentloman frum hrisona. Soro of our area would coincida with somo of that he has crossou over comiin up, ard I wish to state that is tho way wo fool - no chargo at this timo.

* MR. JOHNSON OF UTAH: For the first time tho Gorormont has really turned to thoso govornod, and it locks unfair to nne, and I bolinge that District 1 Advisory Board will boar mo out in, it, that wo don't wat somothing for nothing; that inasmuch as the Prosident and the Socrotary havo ofierod us this oiportunity to vork with thom in a solution of our nwi problems that wo not ask them to pay all tho bills. I woujd like to assure you that in my opinion unless wo do this thing and do it right wo wij, bo subjoot to olireaviontio rulo as wo hnve had in tho Forest Sorvico, and I am sure overyone of you havo fought that all tho way. It took them 25 yoars to do what wo have dono in 17 munths . Thoy have not our good will now, and I want to assuro ire chipofitor nhe his sixporiors that they have the good will of a lot of us in 17 months. Wo aro viling to pay in our district I am suro.

MR. CARPENTER:.. Mr. Johnsun hos como back to somethine you hovo hoard before. Tho man that pays tho price calls the tune,

MR. NILSON OF WYOMING: I may bo out of ordor, but I want to ask whether or not copies of this record, will bo avilablo to tho stato sssocintion.

MR. CARPENTER: Copios of the rocond will bo available to any intorostod party. It will bo a public dooumont.

MR. WILSON OF. WYOMING, Thon wo can seouro copios of it aftor it has boon mimeographod?

MR. CARPENTER: Yes: ist.

… is h

MR. WILSON OF WYOMING I am not in a position to sponk for Wyoming bocauso viyoming has not yot caucused. It soems to mo that wo have got the cart bofore 
$\Lambda-14$

tho horso. Wo havo in many districts, orio in Wyoming, and in many others, presontod to tho Dopartmont for approval cortain rulos and 'rogulations that aro not bound up with ony othor foos or any othor policios, and until wo the somo action, some approval of thosi rulos so the lical advisory bionrds may know the ncasuro of thoir control, I am inolinod to beliovo that we aro not in a position to discuss foos. "Wyoming 'wil I havo' to onlucus boforo they nan discuss thom, but I do think' wo "shou?d know somethirg about tho anproval of thoso rulos for rango practico adoptcd by tho advisory boards, wich woro to bo approvod by the Dopartmont of tho Intorior, semo of whjoh havo boon in Washington for six months.

MR. WILLIANS OF UTAH: I want to stato I novor obtainod tho pregram until lato last ovening. Not knoring'tho "ccintiont's thoros, oun advisory boards'and our constituonts oonnoctod in that district have ncvor caucusod and No. 3 : Grazing District of Utah is not preparod to act along this subject. I would liko to soo this, if possiblo, hold ovor until a lator dato boforo wo have to go into a mattor of voting upon this $i$ ssuo.

MR. CARPEITIR: Boforo I rocomino tho noxt sponkor I brish to say this to Mr. Wlliins, that it is simply brought up horo in orilor that you may sco tho divorgont national issuos. Herotofor you havo soon only your own district and your ovm conditions. Now you aro witnossing and lpolring on this grazing map from Cannda te old Mississippi and hoar oach part give thoir points of viev.

Aftor this is discussod in your committoo this" oveningt, ycu vill trico up tho mattor so that it can bo oxprossod by stritos tomolrow ad if at that timo you do not fool you can roach a fair docision, then e conforonce comnittoolwill be appointod. Thoro will bo no prossuro brought to boar to ocd if thoy can got togothor on a rosolution:

MR STONE OF UTAH: I do not fool wu should bc assossod at this timo. Thoso tomporary pormits aro not worth a "root" cs j. liok at it. Tho stockmon fool that they aro as bad or worso off than wry woro before the thing was innugurated. Thoy quostion our rights and thoy hevo mado tho coisiry all oomon use torritory. Wo arc assosscd on the cattile; and wo donit focl lile wo should bo assessod until it is in working ordor.

Maybe I don't soo it just fair, but I have a mrach rind horo racently tho advisory board havo soen fit to hivo its ow rnombors as rinors. A shocpman is the ridor in our district, and ho just rocontly redorod a hord of shecp to put a camp within a milc of my placo, within d holf milo of my funco. I don't fool like paying a foo until I low I havo got somothing to pay on, thon I im porfoctly willing to do my sharo. Fivo conts for cattlo and ono cont for shoop would bo al. I right. I don't think it noods te bo fjuvo: yoars from now. As soon as tho land is classifiod and wo know what wo havo got, I am porfocily willing to pay my sharc for it.

MR. CARPENTER: I wond or viho ho snys a liconso is not worth a "hoot" .- I wondor about thoso appoals; - hundrods of thom, - thoy woro deniod liconses, what about thoir "hoots".

(Lnughtor)

MR. WYATT OF COLORADO: I am not spoaking for tho advisory board on which I sit or tho dologation with wich I como, but as an individual. Whilo I am a shoopman and holpod to hiro $n$ rango ridar, wo hirod a cattloman and ho is doing
fino.

Washington hasn't riny jurisdiotion over a ridor. Tho advisory bocrd can hiro him botter than thoy on in Washington, or oven Salt Lako, or Colorado, as far as that is concermed. Tho last fow hours of boing around this hotol and listoning to various dologitos from various States; thor socms to bo a fooling that tho stockonan wants to pay as ho' goos. Tho livostock man has novor askca for a subsidy from tho Govommont. Ho has triod to pay his dobts and obligntinns $\Lambda$ s I hoar tho tnlk I havo the improssion that the nvorago livestock man wants to start payjng now. Porhaps not too muoh, but ho vants to know whoro ho is going. Ho 
wants a pormanont pormit just as soon as ho can hate it:

Now tho Departmont may toll you, Mr. Chaiman, and the so dologatos -- wo fool you aro ono of us of courso -m that they aro not propared to issuo a pormanont pormit. How long should it talse to got thoir affnirs into shapo? Thon a. man will. lnow whoro ho is golng. Ho can go to his bank or his financial afcncy and ho has an asset. I boliovo a happy modium, as tho Gontloman from Hyoming statod, is tho bost solution. Wo might got togothor where wo would start paying on a temporary basis, but not for vom long, "and got on a pomanoint!basis within tho noxt fow months, but I for one would rathor bo on a pomunont bnsis whero I know whoro I am. going and ean adjust iny fimar,cos and haro somothing, to show for the work which.I havo done through the yours, and I thinik a gront'many fool that way.

MR. MATHIS OF ARIZONA: I am not spoaking for the boird. Wo havo not enuousod on this mattor. I am just spoaking my oin individual vious on this. Thoro is a tomporary period now that wo havo licenses for: that I think wo should pay for the administcring on, but $I$ don't think, until wo got somothing pormanont; that wo havo a, real assot that wic onn depond on and offor as collatoral that wo should havo to pay anything into tho county or tho stato.

Wo aro already taxod until tho Fodornl Govomiont hes had to come in and holp us out of this condition, but whilo operating lucior this tomporery poriod, in which timo vo hope to adjust our claims and our wishts, thoro is oxpenso that Is necossary. Wo con't got by. Down in our part of tho country wo havo alroady incurred bilis that wo do not lowow how to pay, Wo can't assoss, wn to try to got it by contribution w thoro aro only a for, ns \pm in 0,11 other things that aro finaneod by contribution, that would pay. So I think it would be right and proper that we bo assossod for tho edministoring of tho affairs in ench district and that only, until wo havo a pormanent sot-up.. Thon after wo got our porminent sot-up I think wo can work with our; county officinls and stato officials ald adjust our tax so it will bo in proportion with overyiching olso. Bit nort to bo assessed, for thet purposo, and schnsl purposus, it would bo $n$ double asso's smont that tho livestock intorost can not stend at this timo.

MR. LIEE OF IDAHO: In Idnho wo havo throo districts. Ono of thom its organized and two of thom havo not boen organizod. Wo asleod tho boys from the districts that havo not boon organized to spcak for themsolvos. Spoaking for tho district that $I$, roprosont, No. I, wo disoussed this informally and fommily in sovoral mootingsiand triod to oomo to sollo aerocmont about vhet wo would do about this foo or assossmont, whichovor you would like to call it. wo adopted cortain rulos that wo askod tho Dopartmont to pass for our district. Among thoso things wo askod to do wh to claseify tho land and d] so classify tho peoplo, tho applicants that should be issued licensos, and wo egrood at such timo as thoy could classify this land and soo about what tho foo would bo worth on that, and also classify tho pomittios and soo whowas going to uso this land and who would bo allowod to uso it.

That mont, of courso, it would bo sogrogotod, somo part would bo in pormits. Thero might bo somo torritory in our district that vould bo advisablo to run in common although wo aro not ablo to agrco on how that should bo dono. But until such timo as the land, was classifiod and tho pomittecs classified wo could not agrco as to whoro wo could assoss oursolvos for ndmiristrition bocauso wo don't havo anything to administer. It was probably at our organization that thoso tentativo feos originatod. Wo ngroed aftor this vas sot up that wo night pay one cont a hood for shoop and fivo conts hond for cattlo as a startor that wo would havo somothing to go on. Wo realizo that thoro would havo to bo sone kind of policing in tho district so that every follow would get what ho paid for.

Wo roalizo that in Idaho that wo aro difforontly situated from the southorn part of tho. Unitod Statos... I undorstand down thoro that thoso boys here pormits, and thoy pay for it whero they can graze tho stock the yoar round. Up in our torritory, tho imodinte vieinity that $I$ represent, c.l1 of the land that wo uso, all of our stato, about $75 \%$ of it bolongs to tho Goverimont as forost. The rest of it is in agricultural lansed. Inds and privately-ownod land.... Since tho Govormont allowod a 640-acro homostoad, aj groat doal of it has pessod into tho hands of the oounty, and tho: publio domain is vory small. Part of our grazing sot-up, excopt'in ono part of thic district, that is what wo call tho south sido of Snako Rivor. Tho rost of tho territory thoro is just a littlo hold-over ground in the spring of the year until tho peoplo can got back on 
$A-16$

thoir orm land or got on tho forost roscrvo. Whon that hos boon olassiftod and tho follow looks for tho grass, ho vill probably think wo are antitlod to a littlo bonus for staying thoro tho longth of timo that wo do.'

I am not spoaking for our district now as to whother wo vill mako the assossmont, but I-boliovo tho consonsus of opjnion from our part of tino stato would bo that this assossmont should bo vory nominal until such timo as wo havo a pormit and know wo aro going to got somo oonsidoration for what wo pay for.

MR. MOITGOMERY OF MONWANA: I am not a mombor of a Taylor Grazing District Advisory Board. I tako it you aro asking for discussion from those who aro not. In my work botwoon tho stopk grazing associations, which havo gono quito a long ways in Montana, and tho Taylor Grazinp Act districts, I havo found oxprossod, desires on tho part of tho stoclonon of Nisntana to pay thoir way for whotovor thoy got. I hevo found this, to mjr bost knowiodge, that thoro hos boon no., if liconsos issuod in Montama as yot. The stoclanon of Nontana, thoroforo, would like to know, in discussion of foos for liconsos, wht thoy aro gotting in $a$ liconse. Would tho Chair ploaso oxplain just what liconso moans?

MR. CARPENTiR; Mr., Montgomory, I think you hilso in viow District 1 , in Montana, whoro, in ordor to porfoct tho stock orgnitzotions, no liconsos havo boon issuod. But it is my undorstanding that in other districts in Montana liconses havo bicon issuod tho soino as othor districts in othor statos ... that is tho tomporary. grazing privilotos.

MR. WOOD OF MONTANA: I was Ilstoning to tho difforont onos in rogard to focs, and I bolicvo a largo majority in our district will favor a foo, and that sooms vory roasonablo $-I$ and 5 - but not until, wo hovo somothing for it.

In our country tho land is chockor-bonrded by railrocd land, doodod land and Stato land. Tho Govornmont icnd is in smil tracts. I. think practically all of tho pooplo thoro will favor an cillotmont, and $I_{\text {, think they }}$ is 11 bo glad to pay the foo just as soon as tho lend can bu clasisifiod. But I hnvo noticod in tho advisory board ... I. can't vory roll spoale is $\mathrm{s}$ the board but lnow of our nombors of our advisory boards - I just mot thon at tho choor as I camo in -and I am just spoalsing for mysclf $F$ - but whet I harn lacinod on tho bonrd, and I am satisfiod that tho stoclonon in our locality wolid bo porfoctly satisfiod to pay a foo, but thoy mant somothing for thoir woncy; thoy want some protoction.

Wo havo not any largo tracts of Govemmont land as thoy havo in othor localitios, mostly doodod land and Stato land. I think tho only satisfaction would bo to alslot this land. So far in our country our advisomy board has agrood on ovorything that has como up, and thoro is no quostion botwoun the two intorcsts, and $I$ bojiovo and approvo and would like to soo it on. a paying basis as soon as wo can got. somo protoction, and I highly approvo of the plan that the sccrotary and Mr. Carpontor hovo workod out, and if it can bo roforrod to the advisory boards - tho non who hevo boon on tho range for yoars ... I havo boon on the rango for almost 50 yours and $I$, know tho rango mon wis.l mybo work that out bottor than samo smartor follow in washington. Wo would lisso to soo the land classifiod.

MR. MHITE OF UTAH: I don't think that wo aro so rich concomod by tho foo wo are going to pay as wo aro about tino managoment of tho rango. I havo boon ruming on tho dosort, Utah and Novada, dvol' sjnce 1934. I am also runing on tho dosort at tho prosont timo, and I find that tho Taylor Grazing Act has not climinated tho hazards on tho desort. Ono troublo wo aro having at tho prosent timo vo aro over-stocked. Thoro is moro shoop and cattlo on tho rango today than thoro over has beon in the history of tho countiry, I boliovo. That is tho caso in our district.

I think that as to foos it doponds on the locality in which wo aro running. Utah probably is difforent from othor Statos. Utah aind Idaho and Novada probably aro vory similar, but, wo aro not so much concomed if wo will get value recoivod in tho arourt that wo pay, but I want to toll you tho shoopmon aro running: $a$ 'big chanco when run on tho dosort. Thoy aro not assurod of food. Thoy aro subjoct to hoavy snow falls at any tino - they aro worricd continuously about that... nnd it is vory nocossary, that wo havo supplementary food that wo havo to buy. Wo aro alroady taxod to doath. Wo aro taxed now to tho extent that wo can not pay. thom. Wo aro taxod mow moro than wo woro during good timos, and wo can't stand to pay vory ruch for tho grazing that vo, aro rocoiving at tho presont, timo, and I think wo only should pny tho

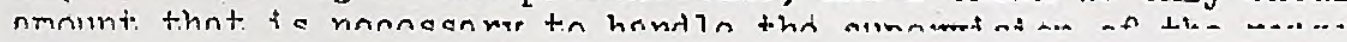


MR. COX OF UTAH: I an not spoaking for any advi'sory board, but I an, howcvor, spoaking for the Southorn Utah Livostock issociation wich reprosents 80 to 100 livostockmon and ovor 150,000 shoop. Our association has rosolved agaimst pssossing any foo undor tho liconso poriod, or until such timo as tho livostock industry can carry tho lond. Wo focl, and wo havo beon led tolbolicvo and lod to undorstand by tho Dopartmont, that there would bo no focs during tho liconse period. Wo undorstand that this law was not a ravenuo hoasuro bat a moasuro to rohabilitato tho rangos and tho livostock industry, and in the law it has diroctod tho socrotary of tho Intorior, at his discrotion, to rotuid in pert or in wholc any foos during cortain onorgoncics, ond cortainly tho iivostock industry was'novor in-moro of an omorgoncy or a bad position financially than wo aro today. Tho only difforonoc is wo think somo of us can soc a littlo daylight.

Thore is plonty of precodont why tho Govornnont, why tho Dopartmont' should carry this losd at this tirio. They havo gono out w.. tho Roclamtion Department just as an oxample - and spont milizons for dors to roclaim a fow hundred. thousand acros of land for irrigntion purposes. Combinly thoy should spond some monoy to rohabilitato tho public icinds. Furthor, they aro sponding monoy to rohabilitato and bolstor up or sutstaizo, if you plonso, othor business, and wo think wo aro ontitlod at thj's timo to ke rencibilitatod. Wo aro brek of tho law dow that way a hundrod porcont, and wo think it is good, rnd wo aro back of tho Departmont - but thoso are our sontiments rogarding the foos.

MR. CARPENTER: Gontlomon, on account of tho timo, I vill hevo to intorupt this intoresting discussion; but it is not ondod. Lot ro sumiarizo it by saying that it is vory ovidont hero that wo wll not bo ablo to take up tho subject of f'oos and roach any reasonablo conclusions until wo havo all of the facts that wo heve to discuss, which moans policios, c.llotinonts and tom pormits, and wo como back to the discussion made by Mr. Willing that it would bo unfair to try to ronch a: solution on this until you havo loolcod ovor tho whole fiold, and for this roason and bocauso it is two rinltos to cmolvo I am. aftor a fow statoments and ono othor important itom of businoss, going to adjourn this moeting, and. then wo vill tako it up whoro wo hnve loft off, but baforo continuing tho subjoct wo will mako a statmint on poitcios, rnigo al?otments and tom pormits, and thon if it is tho wishos of tho conferonco wo itill go into tho matter of policios in ordor that by 7:30 tonight whon wo meet by statos you may havo covored tho fibld critiroly and bo bottor able to fit tho foo subjoct into othor mattors.

\section{I am Going to recognize Mr. Marshall front tho floor.}

MR. MARSHLLI (Socrotary of tho National Viool Growors): I ask rocignition for -. I ask it as a friond of the court - tho chiof difficulty of this foo question is bocauso wo aro short on grass. Wo don't hevo anything like a worling, idca at all as to how much nonoy wo aro talking about. The.t is why I ask this quostion beforo you adjourn so that thoso mon in thoir various conforoncos after lunch will know how much monoy you aro' talleing about.

I would like to ask a few questions. On pago 4 of tho program roforonco is mado to paying all cost of administration ani rolioving the Fodoral Troasury of that burden. Doos that rofor to tho 412,000 ?

MR. CARPENTER: YOS.

MR. MARSHALL: If you will givo us tho information I ask now, I think I can work out for your information how diany conts por hoad per month wo will have to assoss oursclvos. Wo know the Bill. Now who is goinf to pay it? Undor tho liconscs now in offoct, what is thoir cquivalent and how much?

MR. CARPENTER: Thank you, Mr. Marshall, for gottine dom to "brass tacks" on this. Roughly thoro aro six and one-half million shoop iiconsod. They wero liconsod indofinitely for tho year, most of thein.' As to how many months thoy run of tho yoar, it will bo your guoss as woll as jine .. probably somowhoro botwoon 3 and 7 months - difforent in difforont distriots. Talce an avorago ifu"
you will. 
Thero aro ono and ono-half rillion cattlo, approximatoly, and tho numbor of months thoy run will bo sonowhat tho snmo - longor in tho southorn statos and shortor in tho northorn statos. :

irR. MARSHALL: Whon you divide that into tho Bill, thoro vill bo a rudo shock to the boys. I. boliovo you are goifig to mako somo statmont as to tho poriod?

MR. CARPENTER: In ordor that wo may talk about tho samo thing, I suggest that in tho figures you bring brek this aftornoon that you stato whother you havo calculatod on a fivo months basis or whatevor you havo figurod in order that wo may not bo talking about difforont things.

It is ovident that boforo wo got dow to actual figuros thoro is going to be sono discussion. But a sound bnsis is tho full sotting forth of all the fncts. Wo will givo you tho exact figures on horsos, goats, cattlo and sheop as soon as wo corio in this aftornoon. Wo will thon continuo foes for a short timo for discussion and $g_{0}$ into policios in ordor that wo, hay fit ono into tho other.

Now' gontlomon, boforo wo adjourn I am going to ask all of tho dologites, both of local boards and stato boards, that aro hore, to romain in their scats until they havo fillod out tho rogistration card, and that they hand the rugistration card in oithor to a mombor of tine Grazjug Sorvice at tho door or at the tablo, in ordor that wo may havo a list of tho dolegates who aro present. Let no romind you, all delegatos will bo roquosted to bo in their soats by $1: 30$, but that others will bo askod not to como into tho roon untjl 2:00 in ordor that tho statos may tako parts of this room for thoir state to clect their stato. Chaiman and got their prolininary nequaintanco which will bo perfocted this ovoning at 7:30. At 2:00 $0^{\prime}$ clock, and thet moans exactly $2: 00$, tho conforonco vill bo rooponed. Tho delogatos will tolso thoir rospoctivo soats, and tho audioneo nlso, and this discussion will bo continuod.

At 2:30 any dosiring to attend on tho Roof Gardor, tho discussion of' salo, leaso, and oxchango of lands, at which First $\Lambda$ ssistewi scorotary Walters and Mr. Havoll will bo present, hay loavo this oonforonea and go to that, or they can go direct to that at tho timo if thoy wish.

MR. METZ OF WOMLNG: I wanted to eall your attention to the matter of Soction 14 and 15. $\Lambda$ groat many of tho mon who want to take part in tho meoting hore want to also talko partin tho othor. Practically overybody wants to tako part in both. Wo wantod to taje two minutos and asle if wo could not set that timo somotino in tho aftomoon right here in the saro neoting, at tho same placo, with tho samo officors, so wo could bo at both mootings. I an vory much intorosted, and I lnow a groat many othors aro, in tinis soction 14 and 15 , and also in tho organization undor your district. I rospectfully ask for a rovanp in this schodulo.

MR. CARPENTER: Mr. Motz has suggostod that a largo numbor of thoso who aro interostod in Soctions 14 and 15 , salo, loaso and oxchango of lands, do not vish to loavo this assonbly to attond tho othor mooting. I will; ask in gonoral whether that is tho sontinont, ... that you do not vish thoso nootings to go on at tho sano timo. Is it tho sonoral fooling that wo should not havo tho salo, loaso and oxchango moctings whilo this is going on? Lot no hoar by "ayo".

\section{AUDIENCE: Ayo:}

MR. CARPENTER: I will ask Mr. Whltors if it will suit his and Mr. Havoll's convenionco to opon tho mooting on tho Roof Gardon at $5: 10$.

MR. CARPENTER: (Aftor a short whisporod discussion vith Mr. Maltors). Mr. Walters suggosts that that part of tho timo bo takon in tho assombly. Is that your wishos?

\section{SEVERAL VOICES: 'Make it hore.}

MR. CARPENTER: It is suggostod that instond of having it in anoticor roon that we attempt to finish discussion of polieies at $4: 30$ and thon go into tho 
matter of salo, lcaso, and oxchango right in this room. How will that suit you?

(AppJouso).

MR. CARPENIER: That will be tho ordor of businoss and when tho delogntes havo signod their cards and handod thom in, the mooting will bo adjourncd to $1: 30$ and $2: 00$ o'clock.

(Recoss for lunch at 12:15).

\section{Aftornoon Sosision jonuny 15,1936}

(Mooting callod to ordor by Diroctor $F$. R. Carpenter at 2:00 P. M.).

MR. CARPENTER: Gontlomon, it is cxactly tiro diclock. If you vill rosumo your placos, the moeting will cone to ordor. (Pause to perint audience to becomo seated).

Gentlosien, we havo a picasant surpriso this aftornoon in hoving with us by chance fissistant Socrotary Chapian, whon you $0.1 \mathrm{i}$ know and who startod tho Taylor ball rolling in the way wo hope to keop it rolizing. Assistant Socrotary Chapman.

MR. CHNPMAN: Evary timo I try to speak beforo one of thoso things (roforring to the microphone). I find ny power rums lonicer than it does and it broals off on me. So I will got out hero away from it and talk rjgint to you.

It has boen about two yonrs sinze wa stood in this roon with about five nombers of the Taylor $\Lambda$ ct Comittoo thet, ocje out from Washingtion. I romombor sitting hero that sano day starting in as "groon" as some of you here this morning on that same $n$ ct, and I can yot sec thet follor from fyoming sicting ovor in the corner and isking thoso anmoyins quistions. I want to teli you ho doos not only nsle them hero in those nectings, but llo koops coming to Washington asking thom. But anyway, aftor following mo over olcven westorn states he finally found that wo wore trying to work out this net for the benofit of tho poople for whon it was passed. I ar sure that Mr. Vililson, to whon I an reforring, fools today we have mado at least somo degroo of suceoss in carrying on tho oporation of the Taylor $\Lambda$ ct.

I did not como horo to mko a spocoh. I dropped in a littlo lato to this mootins, and it makes no fool a littlo like tho boy on the first day of sohool. Ho ran in kind of out of broath, kind of lato, and tho toacher patted him and said, "You aro a lj.ttlo lnte. Do you know your $A-B-C$ 's?" Ho snid, "Hell no, I just got horo." (Laughtor)... Leavo that off the rocord, Ic.dy, plonso.i"

Woll, a lot of us just got horo whon it comos to tho oporation of this act, and wo are all trying to learn the $A-B-C{ }^{\prime}$ s togothor and carrying on and vrorking for the intorosts of tho poople in this countr. I want you to know that I approciato the opportunity of stoppinis in. to sciy hollo. I' sow many familiar facos, espocinlly of thoso who sat in this first enforenco here. lihoro is Mr. Johnson from frizona? I an sure ho has oitior sold or bought the Arizona strip by this timo. (Laughtor).

You pooplo havo an opportunity, I thinle, through tilis act to contributo moro towerd the success of roal consorvation, I bolicre, thinn through any othor ono single net that wo hnve on the stntidtes, and I bolicro you aro broad-minecd onough nnd fonorous onough for the interest of tho hrerican pooplo that this act will bo so handlod that it will not ho ono tomed a selfishintorest act; that it will bo ono for the intorosts of all tho peoplo. That is nll I want to say today, oxcopt to thenk you for lotting mo como up for this ono brier moment. Good-bye Mr. Carpontor. I vill sue you in colorndo. (r... $3 \ldots \ldots-1$ 
MR. ClARENTER: Thank you Assistant Socretary Chepman. It is alvays a plensuro to soo and honr you. (ipplruso).

I havo a couplo mosscegos I want to ronil at this convontion, ono from Scnator Thoms of Uta'h that ho wishod to have road sonding grootings to tho stoclmen of tho Utah conforonco:

"Through you I wish to sond grootings to our Utah stock graziors assomblod for conforonco with yoursulf, Mr. Chapman, and Mir. Corpontor.

"I an happy that you aro mooting. Tho need of? tho hour which I an suro wo a.l hnvo is pationco in working out tho Govommont syston for the bonolit of all. Tho Govorniont works bost whon it attodpts to nnd cuccoods in attaining hamony among tho pooplo to bo affocted by its moasures. I nn Elad $\mathrm{Mr}$. Chapmen is going out and that $\mathrm{Mr}$. Carpentor is goine to bo rith you. You havo an opportunity for an oxchnngo of thought from which much; ;oo? may como.

"Knowing that Mr. Chapran is foing out and huvinü had lif. Chapman cxpross a dosiro that I might bo thoro.too, I havo takon it upon mysolf to scnd grootings to you, to $\mathrm{Mr}$. Carpontor and to the stock frezicrs.

"With bost wishos and oomplimonts of the season, I cm, Sincoroly yours, Elbert D. Thomas."

I also havo a mossago from Congressman Taylor for whon the Bill was nanod and ono of tho sponisors, as follows:

"Kindly oxtond my cordicl groctings to tho Mostom Stucknen. I hoartily join with all their frionis in wishing thon o. succossful mooting. Thoy hovo

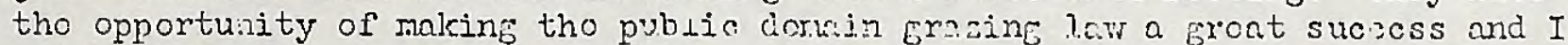
will Eladly do ovorything poss?bio to holp thw. Edward T. Taylor."

MR. CARPENTER: Gontlonon, I cm going to :inko a briof sumary, and thon a statoment about a mattor that. has not ccro into tho taik on finnincos. Then I beliovo you will agroo with no that for tho prosent wo had bottor locvo financos alono and procood to tho mattor of policios with wich it is intorlacod, then cono back to it in ordor that wo nay havo somowhat of a wholo picturo for tho stato Comittioos to considor when you assonblo tonight.

Tho mattor of $200 a l$ assossi:onts has not boon montionod horo; that was in ossoncc a sorvice foo for which you woro supposed to got back what you put in for your furthor uso and paymont. As you know, collcction and disburscmont of thoso foos was stopped at ny roquost, tho reason boing tho question or whethor or not thoso funds woro Foderal moncys, and whothor, is Foloral funcis, thoy should bo covorod in tho Foderal Treasury. If any of you ovor had any exporionco with any nonoy that anybody ovor clainod should go into tho Fodoral Tronsury, you cortainly would not want to go any furthor with it until an authoritativo voico said it was all right, bocauso cvon though thoy min bo ovorcrowdod at Ft. Leavonworth I an suro thoy would build cxtra roons for distinguishod visitors. (Lauthtor).

Tho opinion is in courso of proparntion, and Mr. Waltors was assuroi ho could have it before ho camo out horo, and ho has now virod to got it, and ro aro hoping beforo this conforenco onds that a definito announconont can bo ma. No propor viow of financos can bo takon until tho grazinf foo and the scrvico fco, if you wish to call tho assossmont that, can bo all trikon up and consicorod togethor. That is tho roason I montion it horo in ordor thot you mey huve, in your doliborations and your study of this mattor, thoso facts. I would liko to ask if thoro aro any quostions on the assossionts boforo wo tnleo up tho mattor of policios?

MR. "ILLIAMS OF UTAH: Wo havo just complotod a cnucus of District 3 Grazing District of Utah, wheroin and uncior the acvico of tho aclinistrators durin: tho board sossions of our bonrd mootings, wo loviod nn assiosmont of ono oent a hoad on shoop canl fivo conts a huad on cattlo -- that whs for the your .- for oduinistrativo purposos for tho bonofits of tho locnl aranizntion to bo cxpended 
for the purpose of the advisory board.

In our mooting horo today the graziors of Distriot 3 havo gono on rocord as supporting this lovy that has bocn indo, or this assossmont. Wilo wo nnvo approximatoly two-thirrs or a little bottor of tho assossment colloctcd, wo find it cc.n not bo tiod to tho liconso as ws rivon us the improssion at the timo it was modo. I think, notirithstanding, thoy boliovo 1 is is osscntial and wo havo Gone on rocord that they colloct and ontinuo to pay this assessmont for administrativo purposos in tho loonl bonri's for thoso bonofits. Wo mako this recomendation to you, Mr. Carpontor, cnl wo hope it will moet rith your approval.

MR. C/RPTNTIR: Thank you, Mr. Millinss. And I assuro you that tho wishos of tho local board in this rospect hr.vo my hoarty approvel. However, I foel at this tino that tho mattor of finances me? foos, assosments and budgot; .. thet wo zust cxhaust ovory anglo, and thoro oru a munbor oi possibilitios in which tho natter may bo finally sottlod.

Just to Givo you one thought, tho Taylor fact was passod by mon who had in viow tho Mizpah-Pumplin District in Monton. In tho Mizpah-Puinpin District in Montena - Mr. Nick lionto, the State kengo Comisionor, is hore, ono of tho principal organizors of that district -- thoy hevo "ono railroail, stato, and Govornmont land; thoy orennizod into an associntion and ontorod into a cooporativo agroomont with tho Govermont and tool: over thoso laids, and tinoir feo, which I think runs 1.25 por yoar for ccttle whorons it has boon avoracinis about 1.50 , includes tho sorvico and tho grazing and ovorythinf in ono fco.

It my bo possible that with the covelopment of this fet, you will profor to como unior soction 9 of tho $\Lambda$ ct, which says that jocal. Strto nssociations in grazing districts can ontor into cooporolivo agroenonts ir.t.2 tho Govornmost.

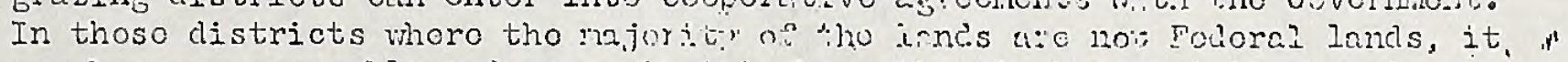

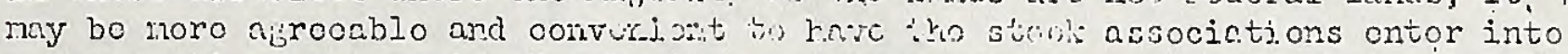

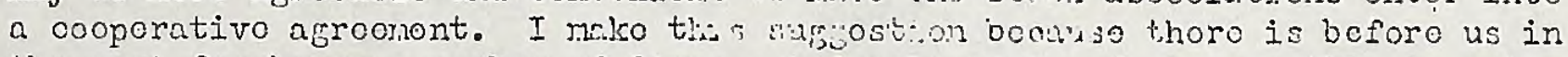
tho noxt fow hours a nuribor wi livoreut devalcmentis of

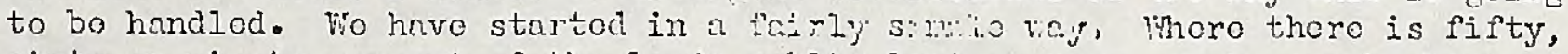
sixty or ninoty porcont of the lands priblic icnit we nave, so to spoak, boen following; ono pattorn only.

It must bo patont to you that in casos whoro thoro is much public domain. lands, tax dofault, county lands, ctc., that the lccal associations aro going to heve to, by pertmorship agreoments or corporations, take over most of tho lands. Furthomoro, that as allotionts aro naie on tho ranco, say betwecn cattlo and shoop, that tho cattlo section is goin: to bo intorostod in tho rent of the lanis in tho cattlo sootion, and tho aheap notion is going to bo intorostod in tho ront of tho lands in the shoep soction.

In some districts in Nevada whero one or two inticiuals havo beon carryinf hervy lonsos of checker-board lant, those indivilus.ls shculd bo rolioved of thrt burdon, and the association, if it is isint uso, or ono soction of the association, if it is catilo or shoop, should take thet oror and prorato the chargo.

I do not wish to confuso the issuo we nre dicoussing by sucgosting many devolopmonts. It sooms to mo vory advisabjo that we should tako just what wo hevo, and, so to spoak, squeozo all tho juier sut of it. Let us seo whint wo can do vith this pattorn, boarin: in mind that tho Taylor f.ct lots us fom local associctions and uso the pattern wo hivo startor? as a stoppinf stono. Now with that caplnnation of tho mattor of foes, and in order that wo con fit ir, what we have to tho pattorn of tho wholo thing, I an goine to launch the quostion of policios, and the first metor on your shect, which j.s on Soction 2 , you will notice is tho mattor of swappine classos II and II undor temporary liconsos.

You will recollect, fontlonen; that at tho Donver nooting, when tho rulos and roculations unior Soction 2 woro subrittod to the stuclaber as lificy woro at Salt Leko City, at Rono, and at Riflo, that your consont wis given that class I licenseos should bo thoso with comonsursto proporty anil prjority, depondont commonsurato proporty and priority, that Class II, bocauso wo woro taking caro of tho iniustry as it existed and not as wo expocted to hnvo it fot boforo tho Taylor $\Lambda$ ct under soction 3 was put into offoct, should? bo thoso with priority 
with adoquato commonsurato property, whoroas tho third class, which was to bo taken caro of only whon class II was taken cero of in full, and class I, of courso, was takon caro of in full, froro thoso pooplo with commonsurnte proporty and without priority. The so-colled "boginnors", thoso pooplo who, fortuncto or unfortunato, havo not boon in tho livostock business. You will rocolloct that at tho Donvor mooting tho foar was oxprossod that after thoso classes woro nado the. thoy would bo loft that way forovor. Tho promiso was mado, accomling to my undorstandine, that aftor a yoar, aftor class I had boon dotominod; aftor wo had gono through this great approisomont of usors, that wo wouid be in a position to roverso Classos. II and III, and aftur thoso with dopencont corucnsurato property and prior uso woro takon onro of thet the noxt class that would bo achitted would bo those with doponlent coms:onsurate proporty anc: vithout priority, and until and if thoy woro taken caro of, thoso with priority but vith inacoqunte commensurato proporty would havo to wit.

That is tho first question that wo hro boforo this conforonoo. Aro you roady to 50 ahoad and havo tho now oircular, which wi.11 supplant Circular No. 2, namo the clasios for temporary liconsos to be ulass $\therefore$. thoso with dopondont comonsurate proporty and prior use, cless II these vith dopondent comonsurato property without prior uso, Closs IJI those "h prior uso without adoquato comonsurato proporty? Tho quostion is now opon.

MR. HENDRICKS OF NEVADA: BOfore you fot nuy furthor alone in this discussion, I would liko to kind of find olit how w stand from the distriots that wore organized? You went out and ocughe tho horses on the range und loft us tho horsos with nothine to pull. Nhoro do wo stund in voting?

MR. CARPENTER: I wish to givo tho conforonoo $\mathrm{ML}^{\circ}$, Hondriok's position. Ho is boyond tho oifhty million aoro limitation in District 3 in Novarla, and logally ho yill bo rooognizod whonovor Concress cmancs the acreago so ho can bo talion in logally. Thero is a tom in low thm applios in lis crse. He is a do facto dolegato. Ho is hero beoauso he is hrive Anc if the inviaca Dolegation ohooso to

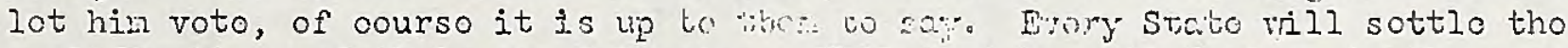

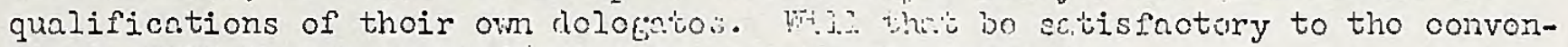
tion? Will that bo satisfactory to you, H... Huniricks?

MR. HENDRICKS: I think so, Mru Corpontor. I jids wantod to fot ny stonding. Thore aro sone vory important quostions coming up horo. I an vory much intorostod in all of thom -- feos and regulations and priority, and all of that. I didn't want to bo talking out of turn.

MR. CARPENTER: By tho my, Mr. Hondricles is Chairmen of tho frizonc. Stato Cormittoo. All tho moiabers of the steto Coinittoe aro invitod to tako part in tho discussion as woll as intorostor stoclenon whothor thoy aro delogntos or not, so that tho mooting is froo for all in that rognrd. In tho mattor of voting it vill bo up to tho Novada Comitteo.

MR. HENDRICKS: That is tho thing I want to got at. You might ta.lk a lone whilc, but whon it comos to voting that is what counts.

MR. CLRPENTER: I oxpoot wo hac bottor hevo this sottlod dofinitoly. Do you wish to havo oach Stato dotornino tho ri! ht to sny who vetos, or would you rathor hevo it dotorminod from tho Chnir or froj: tho convontion? I vill hoer a motion in that rogard.

IMR. TERRITT OF MONTANA: I novo the't oach stato bo nllowor to sottlo tho quostion as to who casts tho voto in cach state.

\section{WTR. IIGGETT OF COLORIDO: I socond tho notion.}

MR. FRINCIS OP UTSH: I think that rotion is c. littlo unfoir in this wry, that ono stato might sot up orodontinIs which mi, wh bo clifforont from another stato and thoreforo givo advantegos or lisicmntegos, whtevor tho caso my bo. Thoroforo, I movo that tho Chaiman sot uo tioc uru cintirils : for tho colegitos horo.

ITR. CARPENTER: The notion is out of orior, lir. Trancis, bocauso thero is a motion boforo tho house. Howovor, wo will consider your romarks as an nrigunt reainst tho motion if wo may. 
MR. FRAMCIS: I would like to move tris as an sumdmont to tho motion.

ITR. THORNLEE OF U'RAH: Sccond. anondinont?

MR. CARPFNTER: The amondmont is soconled. Nuy discussion upon tho

IR. CHRTSTENSEN OF CLIIFORNIA: Fron tho information and instructions sent out by tho Dopartmont tilioro woro four roprosontativos of oach advisory bonrl to reprosont thoir rospoctivo advisory boarls hore. lioprosontativos have boon duly chosen by tho alvisory bonrds to roprosont tho pooplo in thoir cistrict. I roally belicvo that any votine should bo hold by the roprosontativos who wore celocated to appoar at this convonion in line vitis your previous instructions.

MR. CARPENTER: lny furthor discussion? lro yci rocdy for tho quostion? Tho quistion is on the arnondinont to tho motion, which was that tho qualification to voto should bo rulod on by tino Chair and mot sottlod by tho Statos soparatoly.

\section{VOICS: Who may vote on this quostion?}

MR. CARPENTER: If it comos to a oloso voto, wo vill voto by vilco, aind than is thoy coll for $\Omega$ poll roto. I vill mle on thet quostion when it conos up. Thoso in favor of the motion signify by seyine "ny.". . . . Thoso opposud simify by tho sano sign... The :20's havo it.

Wo will now take up tho original motion which you mado, to the offuct that the reprosontativos froin oadi stato should sottlo tho gur.jifications as to who should voto in tho stato caucus. I wish to mole this clonr. Whilo thoy con vote in tho stato coucus, if tho ropros mustives of that stito dosiro to lot thom,

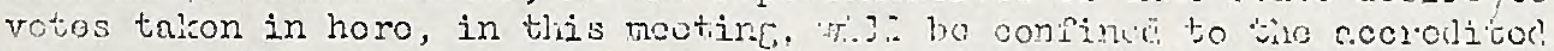

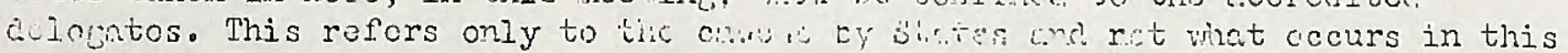

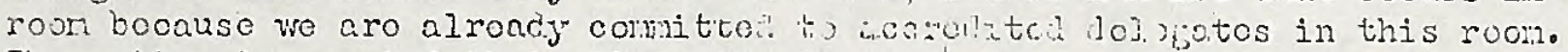
Tho motion is carried that w.jinin tho stats chuscs mo siato reprosontativos can fix the qualifications to voto. Whon jt cows axc, only tho stato dologatos can voto.

MR. WILIIMS OF UTAF! Tho aro Goine to bo considorod c.s tho accroclitod dologatos to voto?

MR. CARPENTER: Tho actual dolagotos will bo tho four roprosentativos from each of tho 34 grazing districts that aro lopally orijanizol and only tiom. iro thoro any furthor quostions? . . If not, we cono back to tho quostion of whother you aro roady to swe Claskes II and TII ju tho order in thich they shall be taken caro of for tomporcry licenses in the yocr 1936.

MR. ANDERSON OF UTHA: Roforo $w$ go into iscussion of that quostion, I woule like Mr. Carpontor to answor this: In detomining this orior of proferenco, is thet a mattor for this croup to cotcimino by our cotion or is it ono which must bo controllod by the conlitions alrondy in the Tnylor Grazing lict?

MR. CARPENTER: Mr. Anciorson s.sks whother suny netion of this cormittoo could or walc havo any offoct on placing those nhoses. Niy answor is this, that tho liconso sot-up is not a sot-up undor section 5 of tho f.ct at all. It is a temporary sot-up undor the Socretery's yowor te co any anc 0.11 things to carry out tho purposo ard intont of the sct unior Soction 2 of tho Taylor Act, eni? having such vide latitudo by thoso words ho hes chosen to sut uij a torporery sot-up that doos not follow soction 3 of the ict, and in his ciscrotion tho dosiros of tho stockmon vill I havo a very jront offoct, so thet it is truo, $\mathrm{Mr}$. Andorson, that it is vital anc. vory nocossary that wo know your wishos, nnd if your wishos aro followod thoy will heve a coutrolling offoct on tho circular whon it is put out. Do I mino thet plinin?

So you c.ro rociding somothing horo now which will bo quito a controlling fretor whon the thine is considered and put into the now circular, provicline you stay on a liconso basis for this year. Lator bil wo aro coming into tom pornits, so it is vory nocossery that wo bnow your wishos 
IR. COMVAY OF COLORiDO: Aftor listonine to the gentlenon horo today and the pooplo have oxprossed thoir opinion that they aro dosirous of roing on a pomanont pomit basis, I fool liko oxprossing mysolf on this class $B$ and. C, and tho fact that ovorybody has exprossod thoir opinion that thoy would like to fot on a solid foundation on the uso of tho rango undor tho Taylor sct, I woulc like to say that I an in favor at tho prosont timo of puttine, Class $B$ ahond of class $C$ on this classification. I fool like tho quickor wo molko this change tho quickor wo aro koing to got on a solid foundation. So I soy, lot's got it $50 i m g$, chango tho classification and got on a pormit basis and stop this arguinont wo aro having horo today. Class C?

I:R. MUINTYRE OF COLORNDO: Doosn't the gontloman moan Clnss B instoad of

MR. CARPENTER: Put peoplo with dopondont cominonsurato proporty without prior uso ahond of pooplo with prior use but no ccinonsurato proporty, but loavo in tho first class thoso that hevo both comronsurato proporty anc? prior uso.

MR. WINDER OF COLORADO: Doos that moan that tho man who has prior uso should bo givon tho opportunity to qualify before tho man who has no colmonsurato proporty with no prior usc?

MR. CiRPENTER: Thet is oxactly tho quostion. Ns lone as you kcop tho liconso syston going, you Givo tho advantego to tho man with tho prior uso and tho dependont comsonsurato proporty, tho icloa boins to givo him sucli poriod as ho noods to hevo in order for the prior usors thet wish to stay in tho businoss to have thoir dopendent proporty in tho right anount, so it will not make airy difforonco obout prior uso boccuso tho existine industry vill havo shapod thousolvos up until thoy havo tho deponiont comensurate proportios that control tho rango, and thon to 60 undur Scctio: 3 of tho Tajior sict which will take caro of thom.

In the moantino you havo cortain proportios. Wr estimato is -- thore is a rather low porcontago of the wholo, but somo proportics -- evory now aind thon you hear of them -- that hevo not heci any uso of tho ranmo, althourh totally dopondent on tho rango, and thoy went to lnow how long thoy aro foing to havo to scy out of this picturo. Thoy woro told dofinitoly thet thoy could not got a smoll of it for the yoar 1935, and for thoso that had ovon a shadow of it. woulc bo takcn carc of. Now wo aro coning to 1936. Do you want to put peoplo without comonsurato proporty that is adequato ahocil of the peoplo with depenclont comonsurate proporty vithout prior uso, both of thom to start in back of those that had both?

IR. TOBIN OF NEVADA: In passine on cpplicrtions in District 2, in Novada, wo woro told by roprosontetives of tho crazing Dopartinent that those who qualifiod as class $C$ applicants woro nutanaticnlly rojocted. If wo mako this roverscl proposol in this circulor, whet will bocone of thoso poople that aro in Class II now? Will thoy bo autoncticnlly rojostod?

MR. CNRPENTER: In crso tho classos ar, rovorsod, thon class I will bo tricon caro of in full, and if Class Il is tarcil caro of in full, Class III will thon be takon care of, but Class III will no: bo taken caro of until the othor two clnssos aro takon care of first. l'hore mey be range onough for alj. threo classos and thoro may not. Practically all of you took care of class I, and quito a bit of II this yoar. Noarly all of you went to class II. You practically all took caro of Class $I$, and you took caro of a lot of pooplo that woro thon on comnonsurato proporty. This is pushine then a little furthor cow tho "scrle.

MR. WHINNERY OF COIORLDO: I thinl you hnvo alroady partinlly aiswored tho first quostion I wntod to ask you, anc that was, isn't that accorcine. to our isenoral rulos adoptod last spring thet this position should bo rovorsod when wo cono to action noxt poriod? 
MR. CARPENTER: It is my understanding that wo woro comitted to rovorso these classos at Denvor. Howovor, I offor the question to this asscribly.

IR. JOHNSON OF UTLH: I take it, Gontlonon, that wo aro askod to docido whethor wo will perpetuato what has boon lenown as tho "transiont man, tho travolling man, or the dosort man," in fact ovor and abovo tho stocloman who has boon in tho stock businoss and owms tho ranchos. It beconos a question today whothor through this liconso poriod wo had not bottor go ahcind and tako caro of the follow that has tho stock. As I understand you, that will bo takon caro of whon wo $; 0$ on a pormit basis.

MR. CARPENTER: Tho quostion was to tako caro of tho follow with proporty ahoad of the follow who had prior uso.

MR. JOHNSON OF UTAH: It sooms to mo at this timo wo should take caro of tho man with the livostock, othomiso wo 80 on rocord as sotting up a now froup of, livestock-ion in the liest who aro not ovon financed or can not financo themselvos to stock tho rango and who loave the dosort man, the man with prior use, wi thout a homo. It sooms to mo it should go on os it is during tho liconso porlod and lot that third man still sit in with his priority on tho rango.

I think I would bo disinclinod to loavo the stock without a homo as lon as it is as indofinite as it is now. I boliovo wo should tako caro of tho stock, and we should sorvo longor notice then ono your on thoso son to liquidato. It sooms to mo that tho prosont arrangement is most sotisfactory.

MR. WEBB OF ARIZONA: I can't possibly, with tho wildost flight of fancy, disongago tho priority of right from cormonsurability. It sooms to no that they aro so closely united thet thoy must be considored.

Now I have, if I may be peraitted to dieress, reforence to a personal mattor. I know of a case in tho stato Land Dopartment in Arizon in the courts for scven yoars and ultimntoly docided by a Suprome Court judgo who lonew no moro about the roal interosts in tho mattor than 762,000 of the so pooplo here. Ono wook after this docision was rondorod, tho contestant who got the decision over mo cano arounc mo and wanted $\$ 10,000$ for the things he won in that court caso of soven years. I didn't buy him foolishly out. I didn't think ho would sell thom to anybody elso, but ho did, and ho cot less than 2,000 bonefit of it, and I lost at loost $\$ 20,000$ in the transaction. Now I lenow entirely throueh tho caso that ho was only contonding for sonething with which he could hold no up. I knevit, couldn't prove it. All right, he got amy with it, and thero you aro.

Now it is absolutcly all wong to consicior for $n$ monent that theso chisolors that try to got in on tho logitimato usors of tho public domain wero handicapped. We know dam woll what thoy intond to do, but we can't prove it. Now it is all wrone.

Now in a rosolution in Grahan County, the Gila. Wator Shed in Mrizona -- I had the distinct honor of drarine tho rosolution -- providing this: That we ask that a crazing cistrict be creatod with this uncorstanding and vith this condition, that tho Fodoral Govornmont, with a roprosentativo thore prosont, understood that the stato of frizono was to havo first considoration in the selection ind tho exchange of public lands, or unless that privilogo of our resolution was rooomnizod wo would not ask for inclusion in a distriot, and with that inclusion we asked for a crontion of the Gila wator Shed District with tho absolute undorstanding, with tho ropresentatives of the Govorninont there prosent, that the stato was to hevo first right on the oxchango of land in orcer to consolidato tho difforont districts of land. Wo are still for that. Wo aro still acainst ovorything olso, and wo went it cistinctly undorstood that wo aro first for Arizona, first for tho stato land control of $\Lambda$ rizona, and thon wo aro for the Taylor Bill.

MR. CARPENTER: Thank you, Mr. Wobb.

MR. WEBB: Now wo vant Arizona Stato lands all over tho State of Mrizona in one district, and when that is done thon wo aro for tho Taylor Bill heart nnd soul. 
Mr. Lubken of California -- just a minuto --. I don't wont to got to talking about two things. Mrizomn and Now Mexico hrvo a situation that these non will sinccrely and honestly talk about that is just as different in the south and the North as black fror whito. Whon you havo a 12-month rango how can you do anything but adjudicate as you go onto it? I havo heard of cases whore they havo had thom foncod up for a numbor of ycars. Now that is not what thoso centlonon hero from Utah, orogon, Utah, Wyoming and Colorado aro talking about at all. They aro living in an ontircly difforert country, so I want to kecp this thing fron missine firo if I can. Whilo wo aro not goinc to shut off any delozatcs, I tako it that tho mattor of nomadic sheep, which thoy do not havo to take caro of in certain localitios, is nevortholess an irportant ono.

In the northorn country prior uso and connensurnto propertios havo boon show in many instances, and whother we aro going to rocosnizo thon or not is tho question boforo tho houso. Thet is the reason I wishod to mako thoso romarles aftor what $\mathrm{Mr}$. Wobb said because $I$ can see his point of view, and it completcly missos firo when you are considering tho situation up in othor statos in the north.

MR. GREER OF WYMING: Do thoso porrits follow tho land or tho livostock?

MR CIRPENTER: Onco ond for all, the land and wator.

\section{(Applauso).}

MR. TAYLOR OF NEW MEXICO: In ordor to got this quostion boforo tho houso, I nove that tho ardor of preferential or preforonce classos for liconsos bo as follows:

1. Qualified applicants with depondent comonsurato proporty with prior uso.

2. Qualified applicants with depondont comonsurate property but without prior uso. property.

3. Qunlified applicants who havo prior use but not adoquato conrensurate

MR. CARPENTIR: Tho notion is mado that Classes II and III bo roversed, that for tho year 1936 tho owner of dopendent comensurate property with prior usc remain Class I, comonsurate property without prior use class II, and prior uso but not adequato comrnensurato property Class III.

\section{IR. SHERIUN OF COLORIDO: I socond tho notion.}

IRR. STMAS OF UTMH: I boliovo we aro Going to do gravo injustico to a lot of peoplo in a lot of statos. We edt lot of shoep - - lot of shecpren who havo not got a lot of proporty. Now if we co this and eliminato, I believe it is going to be a great injustico to all taxpayors to strike out all those pcoplo vithout prior use. By tinis movenont you are goine to ruin a lot of fnmilios and doprive a lot of old peoplo and old womon. If you olininato all thoso pooplo then thoy will bo on tho morcy of everyone.

I lnow a lot of peoplo in my county who, if you oliminato thosc pooplo, God lmows how thoy are coing to livo. Wo havo got livestock-men an? shocpmon who havo plenty commonsurate proporty, how aro those peoplo koins to take caro of thonsclves? I bclicvo it would bo a gront injustico if wo oliminate thoso classos. The bost way is to lot thon stay on until wo fot out of tho doprossion. I bof you don't vote for this bocauso you aro going to ruin a lot of cood farilios in the state of Utah.

IR. CARPENTER: Wr. Staas has raisod the quostion as to what is goine to becone of the people with stook but without tho property. I imagine there aro sone with tho property but without tho stock who wish to talk.

IR. ALLRED OF UTAH: I happon to be a roprosontativo of tho soction of tho country that was fomorly an Indian Rosorvation until 30 years ago. It has boon 
sottlod sinco that timo, and tho rangos adjacont to that country woro boing erazod at tho timo this couitry was throw opon. Wo hrvo in thoro possibjy a thousand pooplo locatod on ramchos oporating in a smll wy, both shocp and cattlo, nin a vory sinal percontago using thoso rangos simply bccauso it was imisosiblo to 50 out with a small bunch of enttlo and hold your ow un pror Grazing not, hopine havo boon fighting for a long timo for passago of the laylor Grazing hot, hopine that it would stabilizo tho ranch undortalcincs.

Now that wo havo this undortaking and wo woro rofusod on tho ground that wo havo no prior uso that was undorstood with mo and with pooplo horo at Salt Lako prolorato that for this yoar with tho comploto undorstandine that in 1936 thoso too would bo rovorsod, and tho land with commonsurato proporty, in and ovorythine olso wo havo thero would bo fivon soro rocognition aftor tho man with priority and tho corrlonsurato proporty, which is all vro expoct you to do.

This man spoko of a numbor of mon that vould be throm out of businoss. That is vory truo. That 'vill bo tho caso with somo of thon. But if wo aro deniod tho ranco adjacont to our ranohos, wo ar an value is ontircly taken of tho ranoh.

NR. CARPENTER: Wo could 80 on with this for hours, "ayc". . Thoso against onos coning on. All in fovor of tho "no's" hove it.

you wish to call for a division? I wish to stato tho motion reain. Tho motion was this, as mado by Mr. Taylor of Now Moxico, that Class I romain the use and dopondont comonsurato proporty, that closs II bo thoso with comonsurato proporty, that class III bo those vith priority without comonsurato proporty. Now thoro my havo boon a misundorstanding of tho quostion.

MR. TAYLOR OF NEW MEXICO: With tho consont of ny scoond, I would like to

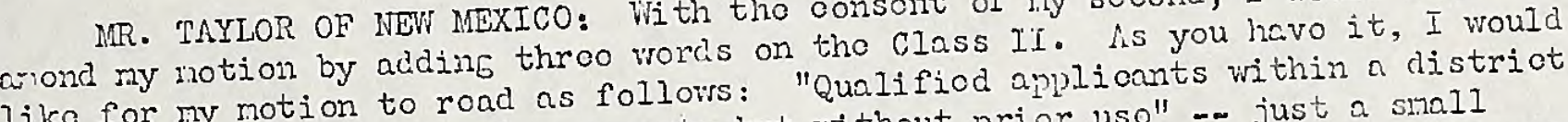
vith dopondont comonsurato proporty but vithout prior uso" -. just a small I think you should rulo on at this timo. In your conoral rulos and in tho rulos wo havo at this tino wo havo placod in class I tho froc usor, ad thoso othor classos $A, B$, and $C$. This motion shoulc, in my and wo havo placed rovorso tho position of $A, B$, and $C$ and Class $I$, if tho Chair so holds.

MR. CARPENTER: Tho froo usor was Givon a proforcod position by tho law. considoring him in our discussion. Thore socms to bo a littlo misundorstanding about this voto. Du you c.ll understand the question? If you do. I ril put it to a voto ovor ngain boforo I put the division. I vill stato tho quostion atain.

The question is, do you wish to lonvo as class I tho man vith depondont

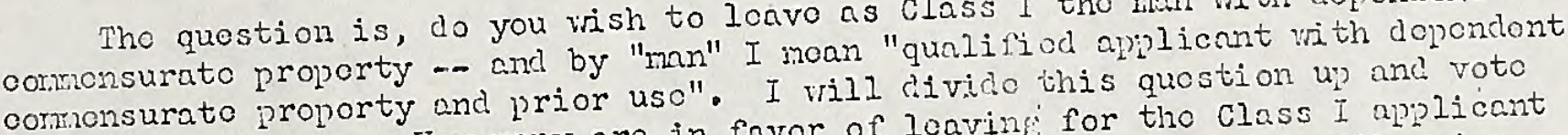
on thon by classos. How many are in favor of leaving for tho class I applicant those with dopondont comonsurato proporty othorwiso qunlifiod and with prior uso? Thoso in favor of loavine him in tho proforrod position sinnify by sayins "ayo"... . Thoso in favor of takine, aftor tho class I is fillod, thoso qualifiod applicants with dopondont comonsurato proporty but without prior uso siennify by scyinï "ayo"... .

VOICE: I think you should havo includod the anondmont stated by tho inaker of the motion. Ho said "clopondont property within tho district".

MR. CARPENTER: I boe your pardon, Mr. Taylor. I didn't catch that. I crn't c.t this timo accopt that amondront bocauso it is going to como in undor arothor subjoct wo aro going, to tako up. Wo hnvo got to tako it up unkor arothor hoarling. 
VOICE: I would liko to ask you if this oould not bo sottlod by tho Tayln Bill itsolf or by the audionce horo? It scoms to no that tho inylor Bill would answor this quostion.

MR. CARPENTFR: Tho Taylor Bill sots up cortain proforred classes undor Soction 3, but as yet, undor tho licenso syston, wo nro not oporatine undor that section. For that roason this assoribly is discussing tho ordor of proforred classos unclor liconscs. I an coing to 60 ahcad and stato this question undor throo hoals, and I an coinc to asle for affirmativo ana nogativo votos undor oach head -.. thoso who bcliovo that tho first proferrad class takon caro of boforo anybody olso is oonsidered should bo thoso qualifiol with dopondent comonsurato thoso in fovor of that sienify by sayine "ayo"... . property and priority -... (no nocativo vetes). Tho "ayos" have it.

Those in favor of talsins caro of tho following classos after this class I has boen tekcn caro of beforo othors cro consicorod, to-wit tho man with deponcient connensurato proporty and othorisiso qualificd but without priority -thoso in fcvor of taleing caro of him first after tho class I is sc.tjsficd signify by sayine "ayc"... Oprosed the sano sign ... Tho "ayos" haro it. Do you vish a civision?

\section{SUDIENCE: NO.}

MR. CLRPENTER: If not, tho thiri quostion has boon rulcd on, to-vit, it leavos in the third olass the man with iriority without comensurate property. Vory woll wo havo finishod tho first subject on tho progran, and wo will take tho next.

IIR. BIGGS OF OREGON: I would liko to ask two quostions horo for tho purposo of Ectting it clcar, a ruline cloar beforo all of the ;ooplo. $\Lambda$ ran who has prior uso and not sufficiont comensurato iroporty is in Class $I$, so far as his comiensurato property goos?

MR. CARPENTER: That is corroct. Ilo can got in partially as far as his comonsurato proporty will lot him, but no furthor. That is : right, Mr. Biggs.

MR. BIGGS: Now thoro is another quostion, that in a discussion here or at somo othor point last yoar, I think thet you stated that tho man who has tho comonsurate proporty but was not usinf it, tho man who had the prior uso but not tho comonsurato proporty, that thoro would a certain poriod in which the man with tho prior uso of changing it all at ono shot.

MR. CARPENTER: Yos, if I undorstand what you moan by that, and I think I cio.

Now the noxt question will bo as statod on pare 2: Are you raacy to divide dependent propertios into classes so that whon you noet as boarc's you will tako ip tho dopendent propertios statod and clivido then into classos, as follows: Thoso within or imodiatoly contiguous to a district, which places a constructhoso propertios that can or hnve bocn used in tion with the pulilic lands of a distriot no mitter whore they may bo situntod.

In orclor that you can sce oxactly what that will c.o to tho shopp licenscos, I have had prepared, and you will fine on your procren horo a shoot in which cach rogional grazior has shovm exnctly tho numbor of applicants thot would bo tolon coro of in or imediatcly contiguous to a district and those thet wero not in ur contiguous to a district. On pai; 2 is tho question, enc tho anolysis is " which is third from tho last shoot. Finil your district thoro and fin? out what wouli hapen. Tho district which ay ons to bo sufforine the most is fizone No. 1, whore only 36 of tho shool liconsocs aro in the cistrict with 47,000 sheop, anc 96 liconsos with 145,000 shovi) corine from cutside of the istrict, but in case any of thoso liconscos are here and thoy think our action ni ht bar thon, you can turn to Exhibit " $B$ " culd find an cmalysis of tho strip uso of cll the sheoi' that will como from Utah but will leavo a surplus rango. 
In othor words, with a rostriction of scason thoro nood bo no cut in numbers oven to those who cro outsice of the district. Mrizona No. 1, California No. 1, and Novade No. 1, if you vill notico fruil tilis shoct, arc tho main districts primarily interosted in this problom. Foucver, ovoryono is norc or loss intcrostod in it.

The quostion is whothor you aro reacly to malco a classification of tho word "dopendency", which will five it a rostrietion of the distanco fron the district. Tho comlaint is mado, and justifiably, from sono of tho boards that thoy woro not pivon sharp onough tools to malec a cutting machine on those districts. This is suggostind givino you a good sharp hatchet.

You will notico that if. you turn to tho Stato of. Now Moxico on Exhivit "fl" that it doos not concorn a singlo liconsce in the Stato of Now Mcxico. So it doos not conocm those pooplo. Outside of the "Strip" in $\Lambda$ rizona, I vonturo to say it vill not concorn any $200 p 10$ in tho Stato of Arizona. $\Lambda$ s to the districts that arc concorncd, this is a very vital question. Thoy nocd not bo sottled? with ono rulo for tho Unitod Statos. Thore nay bo some listricts wish to so into that at this time. Iftor cll, wo aro dealing with two sidos, as Mr. Stans said. Ho prosentod the viows of the men with livostock but no property. Wio havo got to cut ono or the othor.

What do you think about making co classification of dopondent proportios for the yoar 1936?

IR. JONES OF OREGON: I belicve tho Class II men, or Class B as you call hin, should fct vory favorablc considoration. This man has not got propor comensurate property, has had this trouble for tho past five yoars just lilco his noi thbor in Class I. Assumine that you havo a district and throw this ran " out of businoss, and your noighlor isn't c.blo to roplace him on tho rango,. ' what is your Tax colloctor coine to do? What is the man with tho hay coing to do?

Our forcfathers rocolnizod priority. Our Orogon stato laws rococnizod priority usc. I don't soc whoro therc is any justico in covinting fron that policy. In orocon wo have sovornl crood citizons that would be class B. If thoso mon uro forcod into tho merkot, it moans it is roing to affect tho sheop poojlo as a wholo. Evcry hoad of livestock forced into the marlsct ostablishos a now low in livestock valucs.

MR. CARPENTER: Mr. Jonos is a livostocli-man in Orogon, and he was troublod with a cold yoar. Sono of you in the hack didn't got it. I an just going to surmarizo. Ho callod attontion to tho fact that tho mon who did not have tho comonsurato proporty in many casos had had a hard timo for tho last fivo yoars, accucalated dobts, hoavy taxpayors, in many casos purchasers of hay. In othor worls, ho wes holinini tho comunity, and wr. jones folt that a groater consicloration should bo shovm him.

MR. WILSON OF WYOMING: I wantor. to monark a while ago that you could not soe ny "porfect thirty-six", but I didn't roiso my voico. fiftor all, it soons to we that while you raleo conoral roculctions, if wo aro coinc to have this conony, it is a quostion goine to bo clecided by cach local advisory board. Wo have an ontiroly difforent situntion botwen the states on both questions and as betwoen districts within the states. I don't think it call bo docidod in any othor way.

1RR. CARPENTER: I want to say in oxplanction, Mir. liilson sucgosts that tinis has to bc docidoc district by district. I bolicvo it should bo, but I bclicvo this asscrbly should crystalizo opinion in the mattor. It is fair to him and fair to the rost of you, and that is the roason wo nro discussinf it. Wo vill spond a few moro minutes on 1 t.

MR. ORCUTT OF MONTANA: I an heartily in accore with hin. Tha question I want to ask is how can it bc arranged so that this question can bo docided by tho local advisory board? Havo you a suggostion how it can bo arrencecl so it can bo docidod? 
MR. CRRPLNTER: I can soo that wo can adopt an optional rule, . me a rulc that each district can adopt this yoar if thoy wish to, or loavo it alone, but if thoy care to do it, they car tako it.

IIR. ANDERSON OF UTAH: I represent a lario nwiber of wool growors from northorm Idaho that winter in Novada. If this hody of mon should rule that this question of owning the land in the listrict or outside of the district bo classified in a lower class, he would simly bo out. Our set-ups for the sumer aro locatod in morthern Idaho. Wo were forced, some of us, to $i^{\circ}$ beyond District 1 in Utah to winter. Not enouch wintor ranco for the stock wo had on the sumer range in Utah. No drifted into Novada. They accoptor us, made us welcome, and wo havo for thirty or forty yoar: used that vintor rango in comoction with our comon sumer proporics in Utrh. Wo cortainly would objoct to makin̈ a difforont classification of our roperties in rocard to our wintor ranec.

12. HUGHES OF COLORAD: Wo have somevhat the same situation in Colorado. $\because 0$ hnvo to tako into considoration what the assin: of this rule would mean, both from the standpoint of thoso who have gone across tho colorado line and those who are stayine at hono within its lino. There aro approximately 160,000 who cone from Colorado, or crezing in Colorndo in surter, who hate comensurate proporty located in Colorado on the snine water shed as the Utah land. They follow dow that water shed and wintor craze in Utah. Now if you are not coin to pornit that property in Coloraco for crazing in Utah, you nust adnit that those men have a prior use of the rance, that they have acequate comincnsurate proporty in some listricts and necessarily they nust bo eiven their prorata sharo of crazini rights in districts whore thoir property is located, cvon though that moans a vory serious cut in the erozicrs who aro using anc have uscd in the past that land in Colorado.

You can it put thoso sheo: off tho range, becallse thoy hevo both tho comnensurate property and prior use. What aro you coing to do in Colorado with tho 136,000 hoad of shoop that.heve boon usine wintor crazine in Utah No. 6 ? If wro have cot to make room for thom, the privile;e of crazine on public domin is coin: to bo so small that it will not bo of value to anyono as I viow it in tho ristricts whero those 136,000 head of sheop fraze.

It was adritted to tho stoclanen that lines on the prozine districts woro draw juroly arbitrarily. They did not follow past uso and custorn. They dicl not follow water sheds. They stopped at stote lines on tho statemont that thoro was no authority to carry tho district across the state linos. In so far as the lands of tho United Statos of Morica are concerned, State lines are not meterial. I think you will all agrec on that.

Thore is only ono fair way to vicw tho situntion, and that is to talce tho nast as tho critorion of what wo should do in propertios that are copendent or not dependont, besed on tho past use that has boon mede of that property, and if wo violato that principlo wo will find cortain cress thet will bo in $a$ sad fix in so far as public ers.zim: is concorned. I think wo had botter vait until $\approx$ pemanent sot-up is mado. Whilc we aro havinï the temorcry liconse, until we heve found exactly what tho carrying capacity of the so ranges are, who can be cut of $f$ and who is entitlod to remin, we had better not make new creat innovations as has beon nade in comnoction with the public domin erazinf sroa.

The men fron Coloraco went onto those Grazin arcas, grazing on the U.S.A. They have made their investmonts in land, thoy hrve their comensurate property. You havo clram arbitrary linos. On one sicle or the othor sido of this arbitrcry line your riehts aro to be covorned accordincly. Until we are res?y for a pemanent sot- $u_{i}$ ), ten year pomits as viowod by the i.ct, we had botior follow s.s closely as we can jast custom or usaco and not jut a man out nov ani finc. $c$. fow yocrs frow now that ho ws unjustly jut out of tho picture.

MR. WLTERS OF WYMING: It scons to me tho procedure here beini; followed ontirely cisrupts what has ïone beforo, becauso in our district we had ruled

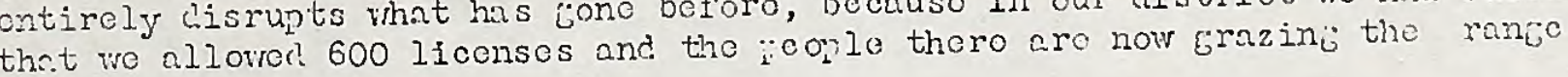


sinilar to what they havo in the prot.

lio heve no nuthority to onforco tho rules that wore pronulgatod by our board, and wo find that in many casos thero have boon flagrant abuses. lie havo promulgetod a rulo which rndo it nocessary to maleo roluctions in a hord ovor a poriod of yoars. Now wo aro adoptin: a different rulo. ro havo changod tho priority by clessos.

Iy quostion now is whothor it won't bo nocossary in tho faco of that to go back. My constituonts vill say that nll is lost and nust bo gone over acain. The liconsos wore prodicated upon the mies then in existorico. Now our rulos will bo difforont, and tho liconses vill have a differont basis entiroly.

MR. CARPENTER: Mr. Waltors his misoc the question that wo are aclopting a now sot of rules to guide tho bonrds by in 1936 than in 1935. I.o cortainly aro. Thero is no question but what wo aro malsing chnines in thon, and I don't want anybody hore to think wo cro not, and ovory resolution horo moans thousands of dollars to hundrods of pooplo. The point wo can't eot away from is this: Wo started in to aim at o cortain objoctivo wich the Taylor lact gavo us, thet tho rights wore to so with erazing land an! wator. It said nothine about prior uso. That simply could not heve boon put in vitinout a tromendous liquirition and bankruptcy.

In orclor to civo the oxisting inilustry a toporing off poriod, a notlod to cot right and come undor tho Taylor flct and have this dopendent comrionsurato property, tho liconso systom was storted cnd cut as nenrly as possiblo to fit tho industry as it was and not as it would have. to bo to conform to tho Taylor lict. Now bit by bit wo aro tryinis to chango this picturo so that whon wo tako the fincl transition and 80 into tom pormits thoro will not have to bo a groat wronch to c?o it.

Now, Mr. Waltors, tho Taylor lict snys that proferoncos -- this is Soction 3 of tho Act -- proforonces for the issunnco of grazinis iomits shall be givon to those vithin or noar a district. For theyoar 1935 wo dicl not considor "noar" in any sonso. Now we are bringine up tho quostion of whother you wish your tomporary liconsos erantod in 1936 to continuo disrogarding tho word "noar" or whothor you wish to take a littlo furthor step tovarl scction 3 of tho Taylor let and term pormits and put into a socond class those who ere outside of the district, not nocossorily to bar thon but to put then in a class bohind those that woro in a district or imodiatoly conticuous theroto. I rant you to plainly soo what you aro doine if you do it.

1 nattor was brought up by a centlonen hore that it micht bo left to tho district board. If that is tho wishos of the conforenco, that rocomoniation will bo mado to tho secrotary, but do you wish at this time to ive the local board an option of ivine a first cless to those within a district and talking thoso without a district as $c$ scoond class? Unloss you talce some action hore on that tho local board as recards this quostion will bo in tho scmo ir.co in $1936 \mathrm{ss}$ in 1935. Tho question is whothor you wish to givo tho local bond a chanco to mako a Class I and Class II, nccorilin to location of proporty.

IR. WhLTERS OF WYOMIIG: In oxplnmation of tho fomor statenont, in our district a gront many who are coinf out, pursunt to a rulo pronuleatod by us, and are acquiring exponsivo propertios to run their holdings, they aro of tho boliof that tho rulos now in offoct are to bo tho oncis that aro horoaftor foing to bo the basis of their pomit. It is not fair to thom to leavo them assume that they can co out and acquiro proportics and thon find out wo aro wrong. They aro outsido of tho district in sono casos.

IT. CARPENTER: That is a fair quiestion because we have got to conl fairly with both sidos on this.

IIR. REDD OF UTAH: My Good friond, Dan Hughos, risod tho question, with which wo can acroo, who livo in District 6 , litnly. He raisod tho point that wo shoulc follow pest practico or customry, uso of tho xango in determining our 
rulos for alloting those ranges. I think you will arroo vith mo that it was the hopes of those who drafticd the inct and those who supported it the. it would correct many ovil practices that have cevoloned without any remulation whatsoovor.

I think if I draw for you tho posjtion of District 6 and its relotion to wostom Colorado, you can soo it is a very vital quostion to us. District 6 comprisos Grant and San Juan Countios -- botwoon four and fivo million acros of public domain. In this wholo eroat bocy only four or fivo small villagos oxist. Hich tablo-land, vory little irrication wator, just two littlo pimplos of nountains that fivo us sumer rence ancivo us a wator shod. Tho wolfaro of that soction doponds ontiroly upon the livostock inclustry. is you lonow, nost of it is off tho railroad, part of the towns off the railrond f'ron 100 to 150 miles.

Wo havo boon discriminatod acoinst in the mattor of acquirine sumsior raneo. our only assot is tho sumor rango wo now hnvo. Tho fontloman who asks that vic follow the system of followine past practice, iving proforone to those who havo been ablo to qualify bocnuso of their resiconco, bocauso of the location of thoir farns, for permits on notionnl forosts. Bocsuso of thoir qualifications thoy havo beon ablo to co into tho crittlo and shooj businoss in a big way and havo conio down and usod our reneos. Now we could not quelify. Wo aro citizons of tho Unitad Statos. Wo livo just as noar as thoy do to tho mountains of Colorado as they do to our wintor rango. Vio havo becin oxcluded vory larelely from the suniner rance. Under the syston of past practico thoy hevo got both a swimor rango and wintor rango.

I think you will agroo that the pooplo should hevo first call upon the range that is conticuous to thon, who live in that crea and who have rainch " property. It is ontiroly consistont cind in hamony with tho lotter and spirit of the Taylor Bill thet the man who his ronch iproporty in or conticus thinis, we hopo district bo Eivon first considoration undor class for fonkini a livolihood and that tho Taylor Act will oqualize the olior thing out of the ranco. If that thine

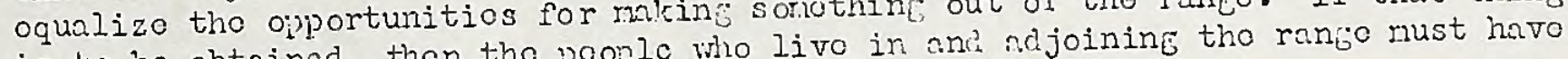
is to bo obtaincd, thon tho poonlo first consideration to that rongo.

I movo you, thorofore, that Cless $\Lambda$, under the major class $A$, thoso who havo lanc or wator within or conticuous to the district, bo first satisfiod.

\section{VOICE: Second.}

MR. MMTHIS OF ARIZONA: What cio you menn by "nonr"?

MR. CARPENTER: Irncaintoly adjucont to.

MR. MCINTYRE OF COLORADO: Sonctimos a thousmil miles in a circlo during the yoar was temod contiguous, othors 50 , othors a humirod.

NR. CARPENTER: This definition will bo tho non rest dofinition of nonrnoarcr-ncarost.

IR. CLfiR OF UThH: Will you ploaso dofine tho vrord "contiguous" boforo I comence?

IR. CARPENTER: Tho word "contiguous" night not in s.ll casos have to bo touchine, but it would bo so irmodiately noor that you would cell it the fringo of tho district in tho usual sonso of tho worc "irince".

VOICE: Dofino "fringo".

IIF. CARPEITER: You aro going: to have to use your cortion senso on that centlomon. Wo aro not coing to make a hard and fast lino, and you know what I moan whon I say tho district and tho imnodiato frinje.

MR. COX OF UThH: Wing the boundary lines of those various districts ware sot up, it was arbitrorily dono. Now, if wo are coine to arbitrarily dofino that 
worc "nocr by using tho word "contiguous", by so doine wo will arbj.trarily bind the various boards to mako thoir arbitrory docisions from an crbitrary basis, not a bcsis of fect. or condition, whorons if wo tako tho construction of tho law os is and use tho word "within" or "near" tho district, it will lonvo tho boards opon to dotormino cach indivirlual caso upon tho facts porteining to that particular caso. Thoroforo, I an absolutoly afainst any such monsuro.

1: LEE OF IDAHO: I laho has not boon taking any vory notive part in this discussion, but whon you try to rike rulos that will ;ovorn ovor a.ll of thoso Statos I confoss wo havo to keop our fingers crossod. " In Icliho wo hac? to tako a Gront many things into considoration, anc. wo mido our ow rulos up thoro boforo ro startod in to classify, and thoso aplicants foll into, you mi wht say, two croat classos. That was tho follow that had a yoar-round sot-up and was ablo to tako caro of -. o oithor ho hre spring and sumer ranco and ho had s. placo to $c_{0}$ in tho wintor tino, ho clon't c.ll tho timo raiso hay but ho had tho rost of tho yoar that ho was ablo to tako of thon. I think wo took a four-month's basis as tho follow who vis ablo to tako caro of thet stock in that district boforo ho was evon able to qualify as a cless in man.

I think you will make a mistako if you ndont rulos horo without making it vory clastic and givo a sroat doal of considoration to tho advisory boards of each irmodiate district. I know in our district thore is nothine that you can do horo that will compl thoso boys to notify a men thet ho has fot to iot out of businoss richt array and put somo $\mathrm{mnn}$ in businoss the.t r.oos not havo tho stook, If ho hns the doponcont proporty and has tho stock, of courso, ho gots some considoration, but as I say wo found two froat classos, and I think it will use all tho range thet will como uncer tho Class $\Lambda$ mon. I think whon tho liconsos aro classifiod wo will find out thnt procticelly ovory ono of tho uscrs in that district will bo class $A$ mon. Tho rost of tho $\%$ oclo that havo no Class $A$ stock and that tho Tnylor Bill will automatico.lily jut of businoss now.

I wish, whilo I an on rin foot, to havo an oportunity to ask you not to make any arbitrary rulos horo that will 0 bacl and bo incorpiratod in tho rogulations that wo must comply with whon wo lo cot roncly to nsk for this tom pomit that wo hopo will cono s.t an onrly into.

MR. OiCUTT OF MONT/Ni: I want to ask what this contlonan has just scich fron Iraho. Thoro is dynamito in this point and. it.should be passoc. very casy or quickly. I'spoak to Mir. W.Itors through you. I sucesstack that tho c.civisory bocrds nood powor. Ripht horo is tho powor you can sivo thon undor tho lnw. If you koop on rocoenizin; aroas as thoy co furthor awey fron your isistrict, tho first thine you lnow you will bo cutting your uso of that aroa com bocauso you havo cot so many cattlo you will bo just ovorcisinf.

MR. CLYDE OF UTAH: ' I an vory much in favor of losvine this mettor to tho rospoctive bonrls. I focl that it is inpossiblo for us to logislato as a jrour for thoso various statos to fit ovory condition. ilr. Rod? just jaintod to you a icture of tho situation wich is in his locality, wich is probably richt.

I would liko to pa.int for you a picturo of our lecnlity, or the district I roprosont, District 2 in Utah. Most of our pomittos, that is spockinc of shoop pomittoos, cono from Utah County, Scnnote and hasteh Countios.

Thoso zon havo spont hundroc?s of thousands of dollers in cotting a sot-up for tho livostock incustry, labince cround, sumor rancos, forost pomits at a listonco from tho dosort. It makos a comploto unit for this inn with invostmont in another county to trail porhnis fifty to a hundrod rilos to a wintor rengo. Thoy havo also on that wintor ranco built wator holes anc havo acquirod iroporty but not suffioiont to qualify undor thrit now rulo.

Tho situstion is this, that thoso ian, inclivicuals, renchors who aro locs.tod suone the fringo of theso distrious, thoso farms porhaps lcostod in fillard county or Jowrott, thoso poop lo who havo hac whost - wo do not wish to discrininate agrinst thom. Thoy should como in on an oqual basis, but to givo thom now tho opnorturity to come in and donand a right whon thoy hevo had nothin: in tho livostock businoss only comionsurato $i$ ronorty - they havo hac? no livostock, anc to cono in and i,ivo thom the proforenco richt ovor thoso mon back in mothor county who havo built $u_{i}$ a sot-up, I feol rould no very unjust. 
In District 2, wo had a ruling - -perhaps wo wore not woll informod -. that land vithin a district which was of tho sano character, that is it was winter range, wes not consicicrod as comionsurcte property, thoreforo I fool that now to entiroly turn ovor our rules and rogulations it will throw District 2 into a chatic concition. Ind I fool that wo should by c.ll woans not rrock. the outfits which havo a complote sot-up snc civo proforcnco to tho individual just bocauso ho happons to livo on tho fringo of tho closcrt. It will ultim.toly ro to this oxtcnt, that it will bo nocosscry for nen who havo livod in lasatch and Son Poto Countios to $\dot{B} \circ$ and purchase tho liconse of indiviciuals who have ranches and no stock. It vill throw thoso poyjo into a speculativo busincss. It will allow then to $j 0$ out and scll to thoso men who are alroady sot $u_{i}$ in the businoss and hr.vo a full yoarmound sot-us. It will put thon out of busincss and givo this man a chanco to soll at a spoculativo valuo his right to acquiro this privilego. Thoroforo, I think it would bo vory advisnblo cund viso to lonvo it accordine to tho district. Purheps tho mulo would work in ins. Rorl's district, but I bolicvo it would worls advorscly to the croator proportion of tho stock in tho stato of Utah.

MR. MILLER OF MONTLNA: It scoms to no in threshing out this question noboly wants to do anythine; to bect cony othor livestockmon. Our intorosts are varicd, so varice that it is impossible to sot up a rulc which could bo applicd to cvery soction of those 10 Statos. Thorcforc, I would like to nako mention, if it is in ordor, that this mattor of prior rishts, irior uso and comonsurability bo roforred to the various districts vithin the states, to the boards of thoso listricts.

MR. COX OF UTAH: I would like to say a for words roceraing that. Thoso non aro opposine Mr. Rocid's notion, but I wondor it'w stop to considor the porcontaco of the poplo that aro affucted both pro and con. I think from tho statistics, in ny opinion - of courso I heven't the focts -. but in iny opinion oighty por cont of the liccnscos and uscrs of tho jublic donain live vithin the district and thoir proportios aro vithin tho cistrict; anc their livolilooc deponels upon tho use of this rango, cmd I can't sco why wo should permit $20 \%$ of the pooplo to control tho range that $80 \%$ of the pooplo uso. I con soc no rosson why bif oporators should be givon a preforence ovor small operators, and I wish to moico on amondmont to Mr. Rodd's motion that it road "dopendent. cominonsurate proporty within tho district".

MR. ChRPENTRR: A notion has boon made to anend Mr. Rodd's rotion in which dopendont comensurato proporty within tho district would be givon a prior classification - - within or imonodiatcly near the district would be given a priority over proportics outsido tho district cond in tho frinco thereof.

\section{IWR. JONES OF UTMH: Sccond tho notion.}

MR. CAIRPENTER: Tho notion has boon scconded and now will be debator wipon.

IR. GREENTIELD OF WYMING: Tho law snys preforences shall be eiven in tho issunco of crazing pomits to thoso within or noar a district. Land ovmors onfagod in tho livostock businoss aro owners of water or water rights. Tho fict dofines who aro cntitlod to proforontial rights.

MR. CARPEITER: Mr. Groonficle has raiscd the point that scction 3 sottlos this, and ho is correct. The point is whother you wish to adopt the point s.nd uso it in tomporary liconsos in 1936, whon we aro not oporating unclor soction 3. Do you want to toko a stop that much closor to soction 3 at this time?

WR. WILLINiS OF UTAH: I rould like to ask Pr. Clydo as to which one oI theso ordors that ho votod uinon when wo chen:; od the classification. Wo havo now votod to put tho mn wi.th comonsuratc property without prior use in Clsss $B$, or in tho socond cless, olininating or nlacinc tho mon thet hos prior usc but inadequato comonsurato proporty in class C. I would like to havo him answor tho quostion, which one of thoso he voted wion.

MR. CLYDE: I votod acainst as it mis carriod horo. 
MR. WILLILMS: I con soo in my birdsoyo $\%$ icw of this soino vory troachorous conlitions that aro going to cntor into tho livostick industry. I on proud to stato horo for your intorost, for your informition, that I heve votod ajainst tho monsuro that has passod horo, for tho sim; 30 roason wo havo bot a lot of mon, particularly in District 3 , that in tho past hevo mace thoir livolihood out of tho livestock businoss. Thoro is not the lard cvailnblo within that district for surmor rangos to bo omol. They haro thoir ranchos dom thore, and they havo mado thoir livplihood out of this livostocle business. Nio hovo the othor class of mon clowm thoro tinst hove node thoir livolihous out of sollini hay to thoso non.

Now then, if you are coing to eliminato thoso mon that hovo fostored the livestock incustry through nll tho reprossing tines wo havo bono throuch, fivo othor mon a fair opportunity that has not accontel tho livostock inclustry in the pest, toll hill to cono in and tako tho place of tho man who has fostorod It, you are goin̈ to put this man out of businoss, d,oing to placo this man on a smellor lovol. I think you havo done somothini dringrous. I think thoso matters should bo loft up to tho auvisory boarls, that the acvisory boards should sottlo this quostion as to whothor wo are goinc to docido "in or noar tho district".

(Ap.lauso).

I don't want to bo a party that is ;oini to holi) to injuro tho livostock businoss.

\author{
MR. JENSEN OF ARIZONa: I havo got a cold, but I vill talk as loud as I, " \\ can.
}

MR. CARPENTER: Kind of uso your hands, that will holp.

(Laucinter).

MR. JENSEN: Southorn Utah cattlunon, sni also shoomon, havo wont to work and usod tho frizona strip for yoar-roum? crazinc. Southom Utah has uscl tho Arizona Strip for Grazinf for 50 yoars, and they h vo acquirod, tocother with tho irizona citizons, lowal rights thoro and hro usod it for the yoar-round croming, and thoro aro a fow shoop horrors that heve lono the vory sano thing.

As I understanc it, thoro are houdis of shoop thet heve beon in the habit of driftinf dom thero. Thoy have conc in thore over and above thoso citizons that used it torethor with thoso citizens thet hevo gmo in and covoloped it. Thero is ono moro thinl;, in that firizona strin, I 'sm't thinle thoro is ono collc.rs worth of proporty that is soind to be aiplicd upon any othor frazing district, and I say that that ono istrict, thet the componsurability within that district should bo the comionsurability that is class $\Lambda$.

Na. C/RPENTER: Gontlomon, at this tirno I wish to mako a roquest -- only about a third of thoso rogistration cords wore turmel in. Vill thoso of you that havo your cords start passing thor! alon; until thoy cono dom to tho gentlonon in front, s.nd thoy will hand thon to $\mathrm{Mr}$. Fyr.s, who will put thon on the dosk. It is now a quartor to four. lio hive tellesd sono on one of tho six questions. Wo hevo four questions thet 'wo hevo not tinuched. Nio s.ro dosirous of tominetine this mooting in timo for nisotlor moting to considor aplicotions undor Soctions 14 and 15 of the Taylor Act. For thet ronson I an goins to ask you, with your consont, to mroposo this procoruro that wo lonvo this socond topic horo, and with tho consent of tho mirers of tho motion that wo not put it to $a$ voto this aftomoon, that all thoso mitices should bo slopt on and? iscussod in caucus, that whon you havo discussod it in your shoro informal croups, you stato croups, this ovoning, ann when they roturn horo tonorrow morning wo will tolso uip the question acain aitor wo hoar tho rojort by statos, cne thon tho question vill be dobated at somo loneth a cin, and whon the voto comos on this floor the accroditod dulogates only will voto on tha" quostion becauso they roprosont tho, 34 clistricts.

Thero is no ecttini around the fect thet you cro slowly and surcly puttine tho nomaic men out of business. Thoro is no use locking that quostion. $h 11$ wo oro dobntinf; is, how frst you mant to do it and what rulos you vrent to clo uso to do it. With your consent wo will co to tho noxt tojic, an? this mattor will bo reforred to the states to be conforrod on in their roons this ovoning and discussec? tonorrow morning aftor you havo had a nicht's sloop oin it, or as much of the night as romains aftor your stato caucus. 
IR. JONES OF OREGON: I wondor if wo could have $\therefore$ copy of the noasuro now beforc tho houso in caucus?

IR. CARPENPER: Mr. Jonos roquosts that tho quesioions that are boforo tho housc be fumishod to tho dologates so thoy con stuly thon. Thoy aro on this shoot (roforring to mincoerniphed procran of the convontion) on irego 2 .

How the thirc quostion wo havo: Should cuts within a cless bo made on numbors of livostock or by rostriction of socsons of usc? Do you understand tho neturo of that quostion? If you cut by numbors, you lanow what that monis. If you cut by scasons, you theroby forcc the nequisition of a lot no ro comonsurato pronorty to carry it for the timo you coulc not got on the public clonn.

I would like to hocr oxprossions of opinion as to which policy they prefor to havo tho disfrict follow in tho draving up of tho now rulos for 1936 tomporary liconsos.

M2. NOBLETS OF MOMING: It has beon ny undorstning sinco tho Taylor Bill becano a lcw, that tho Departiont hec rulce that property acquirod aftor tho first of tho yon 1934 would not bo consicored c.s corr:onsurato holdinds.

M. CARPENIER: Mr. Noblott raisos tho quostion that proporty acquirocl aftor Januery 1, 1934, should not bo consicorod.l Tho Tayloi ict proviclod'thit it should not bo consiclored until Junc 1, 1935. The.t coto is passod, anc? thero is no rostriction on catc of acquisition.

IRR. FEES OF MONTLNA: Doosn't the.t r.lso stato "unloss it has boon used in conncetion with tho livostock industry"?

2R. CARPENTER: No. The lew rakos no distinction s.s to vhother tho proporty hns or has not beon usod.

inR. ALTENS OF WYOHING: You spoak about liccises for 1936 . In our district liconsos woro extended by ordor $u_{i}$ ) until ipril lst, 1936. Fow will this affect us in that cistrict?

MaR. CARPEITTR: It will only affoct the action that you talio aftor tho winter extensions aro over with on tho now liccnsos. Tho question of whothor thore is a proference by soason of uso or by numbers is woforo the houso.

IIi. WEBB OF liRIZON/: I have no brief for shocpmon because I. c.o not know a darn thing about sheop. I don't bolicvo the cattlonon horo thruaton to run over the stato of frizon or aro roinis to dopart sufficicntly from the tradition of those that have cono beforo that thoy wont a dern thine that thoy lon't pay for.

It socms to $\pi c$, ns I havo listence hero, that the principel controversy is botwocn the Forthorn Strip and Arizonc. I ron't thin's anyone south of tho Coloraco River wants any intorest in tho part north of it. I tinink that thoy only want to arbitrato betwoon thon anc ivivo occh ono of thom just whet is conin: to then and no moro. If ivon an oportumity, I boliove irizone can cet tocothor. I bolicvo they conl.

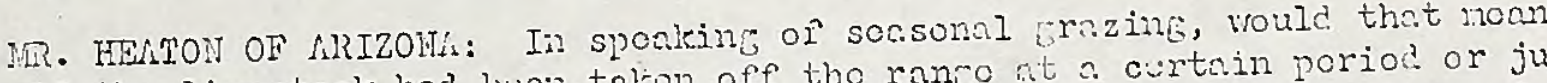
that 0.11 tho livestock had buon telion off the rance a curtain poriod or just a cortain porcont? Supposo a porson had comonsurato ri his to taico caro of his livestock four or fivo zonths a yoar. Houli ho hevo to take thei: all off?

MR. ChRPENTER: Scrsonal uso cloos not epply in your strto or in New I reforrin.' to tho states thet havo a listinct vintor usc sonso:1. You heve a yoar-round range thoro, and the sonso we aro usin; it horo would? not apply in your ste.to.

19R. HERTON: Practically all of the poolo in our district no Uteh peoplo. They might domand sorsoncl crazing.

In. Cinpinter: You aro in tho Strip? 
IRR. HERTON: Yos. Thoy richt rmint to make the cettlo go off if thoy went off.

Min. CIIPEEITER: I cot your point. I talco back what I scid about socsonal w use. Thero suro is scasonal uso o:l tho strip. My furthor romalks?

MR. VIINDIR OF II. MTX: It socns to no the acivisory boc.ris -- in sono districts thoy micht havo to cut by mubors; in othor districts thoy might hevo to roduco the erazini poriod. I don't think you could malce s hard and fast rulo to Eovern all cistricts.

MP. HEATON OF MiLZOHA: Throo-fcurths of tho advisory bocrd nombors in Mrizona aro Utah mon. Now if they cro unitor, thoy can say for all of the cattlo to lenve the Strip in tho sumior time if tho shoop loavo.

NIR. CLRPEITER: lit this timo wo will not fo ny furthor into tho case of Utah vs. Arizona. Wo aro coine to sticle to thoso bopics. If no furthor discussion, I will road tho fourth topic men molro a statciont about it. Tho

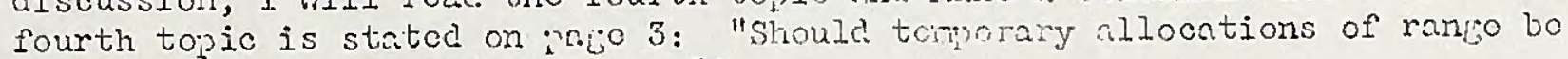
incorporcted in a.l 1936 liconsos"?

Now, gontlomon, wo hovo mado sufficiont rango oxminction to bogin within tho noxt thirty deys in somo allocstions of reneos in ton districts of tho thirty-four. Wo bolicvo, with duc dilienco; thet by the first of octobor of this yoar wo can mako ranco allocations in ovory district in the Unitod statos if thoy aro dosired.

A remeo oxamination consists of an ostinato of the ccrryine copacity of tho reneo in which wo oxpect to cet advice oi the longest rosidonts mel most coroful users of tho ranco ane anko thet ostimato bnsc: on tho noisturo. The only other matter in tho ranco exarinction nocossary to havo is a correct statonont of the comnensurato proporties. Wo spont c.ll lnst your listine thon uip vith what wo thought they oujht to bo. bo havo now ohouln a lare number of thoso in onc listrict in oach stato, anc wo con finish, ro blicvo, checrinc this yoor and bo ready to mikc a rancic allotiont on difforont juinciplos in difforont districts if you cro ronly to hevo it clone.

The ranfo allotnont, I may add, will bo incorjoratod in your iiconso in this way. Prir. A is Grontod a liccnso to run 100 hoad of cattlo. I'he ranco allotmont in his clistrict consists of a simple cattlo conc shoop lino. If that is $\Omega l$ tho ronco allotinont' rndo in that clistrict, he will bo rostricted to the use of the cattlo side of tho line and conied tho riigt for any wilful trespass over on the othor sice of tho lino. The shoci vill bo licensol. on tho shoop sice of the line. If the allotmont has boon mado by cominnity or joint uso, thon a cortain numbor of usors will bo oivon a cortain tomporary c.llotnont that will bo incomoretoc richt on tho fnco of his liconso.

Gemoral rulos of the ronco, pronuleatod by the socrotary, malce it a trospass a violation, subjoct to crininal prosocution anc? a s0 finc, to $c^{0}$ beyond the torms of your liconso.

It will not bo nocossary to ncke s. special rulo of tho ranco to covor tho allotizont. You can hnve a tomornry clljotint of rance mado an? incorporated in tho districts. If that is cone mabes::0 of tlij"s "ihet cors vo cot-

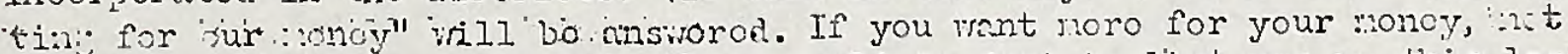
just a noro liconse -- wo had all wo coulin cio just to list you ui this lost

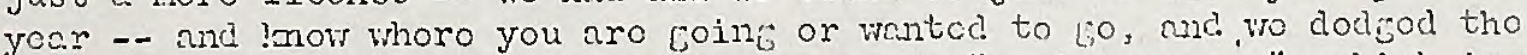
nanica of ranco c.llotnont by usini tho worcls "customary uso", which in tho crso of mny oporctors incluclod a uso fror Honduras to inaslec. ifo ruconizo that ro can't onforco that kind of uso; irith $\approx$ cortainty you can if it is cefinitoly docicod.

Pake, for instanco, tho Nojevo District in Califomia ito. 1. Wo crew 8 . cattlo and shoop linc. I askat ono of the users how, that roricol. Ilo saic? it ws $\approx$ womeorful linc and noboly peid any attontion to it. ihat brinis un tho moter that thoro is no uso puttini anythins into thoso liconsos. It is not coinc to bo onforcod. 
You Gontlomen rocomizo that the Fodoral Govcmment swincs a littlo slower and you clo not got cotion as quickly as you would by coing; to a Justice of the poc.co. You also notico whon it jots into cotion it ists a prip liko a bullcoe nnd henss on a littlo bit longor. Wo nro now going through a procoss of reforring the violations of liconso rules in tho intricts to tho Division of Invosticetions, Dopartiont of tho Intorior, fant thoy aro now properine a lorge numbor of roports. In ono onso thoy hevo roocmencol a proscoution, and I hopo before this mooting is over thet I will bo sulo to cunounco the first criminal prosocution for violotion of the rulos of the Taylor ict.

Do not cot the iloc. into your hoad that wos raisoc. by lin. Stono in our Dopartiont, that wo are just playin: cround and dobsting about sonething. lio aro foine into sonething which is the ensotnont of so much law whin Concross delogated to the Socretary of the Interior, and ho is villing to follow your recoinzonclations in tho mattor.

So those temporary allotmonts, although thoy will bo cooc. only for tho lon:th of your 1936 liconsos, will eivo tho Dopartnont c. Cofinito sonothine to control, which will roslly eivo you somo irotection. Ono min said to no, "How can you toli no to move out of this srec. without tolline mo I can fo to some other aroa"? I. don't know how to answor that. I don't know how to cot this renco into any kinc? of fair roculction if wo cain't mako sono allotmonts. I an vory much aijainst tryine to go too far in this mattor.

I boliovo that in many districts draving a cattlo and shoop lino is as far as thoy will want to 60 in 1936. In liov lifoxico I an infomed that 85 to $90 \%$ of tho liconscos have nlrondy agrook anoni thonsolvos on in? ividunl allotionts. Whorc our studios aro comploto onouih, wo expoct to bocin the first of larch in the mattor of making at loast a tomorary allotmont, and as soon as that has beon triec. out this yonr to fot dorm to tho mattor of term pomits. If wo aro coini; to cot dow to tho mattor of torn pormits and allotionts of rango, which is tho roalization of livestock-non, you. nust bejin novinf; in that diroction. You vill novor got thoro if you con't start to co towards it.

Ho beliovo in a cautious method of ciroch. Thoso who know nothine about your businoss rould just as soon say, "Tako tho Taylor ist and take hor just as sho is rïht now," becsuse they do not rec.lize whet would bo ilono to it. AlI of this liconso businoss wo aro in you can't finc? the word "liconso" in tho lict. It is c.ll undor Soction 2, ivine tho socrotary of tho Intorior, in his wiscom, and I bolicvo ho showroc broat wisdon whon ho naned tho taporine off poriod from the existinc situntion, to do what tho Taylor het provicos in Soction 3. Ho didn't know how loni thet poriod shoulc bo. It my bo only a yoar in Now Moxico. It my bo soveral yoars in othor placos. Thoro aro difforont practicos c.nc difforont fects to substantiato. If you wart renco allotmonts rado, our ranco oxaminations can bo comilote choui his to mako a temporary allotiont and take you ono stop forward townds a tem pemit and a pormenont allotmont of ronc: that is pomenont vithin tho poriod of your torm pornit.

IR. BLLLARD OF OHEGON: Your statonent of tho allotront of lends goos far to sntisfy us. It also coos far to satisfy us in rocarr? to the food proposition.

IR. CARPENTER: Mr. Ballard statos thet tho statoment of ranco allotmonts is satisfactory to his district and also is a sotisfactory answor to tho food quostion.

MR. LEE OF NETI MEXICO: is to tho position in Nov Moxico on allotmonts, wo of Now lioxico oncorso tho allotmont plnn dofinitely, pomanontly, ank? forovor.

2n. MILLER OF WONTINA: I boliove this quostion should bo loft with tho statos. It coos alone with tho financo quostion mich tho states nro to trico $u_{i}$ c.t $7: 30$, and I boliovo tho mettor should bo loft tid tho statos tho samo ss tho fincenco question. 
1/R. CiLPENTER: Mr. Millor, thore is no quostion boforo the houso. Thoso will bo takon $u_{i p}$ in your stato oauous whoro you will only got your stato point of viow, but boforo you go into your state caucus wo would liko to hear from tho various statos so that you may undorstand tho problon of all tho sitatos concomod.

SEMITOR CAUDLIND OF UTAH: I think tho rost constructivo hovo you havo mado so fer is ono lookinf townd imodia to allotmont of rengo. Tho soonor wo mako tineso allotmonts, tho soonor you are coing to bogin consorving tho rango. In our state wo migrato across to vintor ranco in the fall and in tho spring. ro don't know whoro wo aro goinc, wo do'st know how lon: wo can stay. Whonovor you mako an allotmont and moko it pommont mol have stabilizod tho shoop industry. You hevo soved tho shoop incustry. Tho soonor you make tho allotmonts pomanont, tho bottor it vill bo.

MR. MURDOCK OF UTAH: Mra Cauilanc? scili tho soonor you rako tho aljotmonts tho soonor you will stabilizo tho showi in! ustry. I would like to add, Irir. Carnontor, that tho soonor you make the allotmonts, tho soonor you will stabilizo tho cottlo industry too.

MR. VEBB OF ARIZONA: Hay I be pormittod to raiso ono or two points? I want "to say, Mr. Carpontor, that wo in hrizona aro for imodiato oporation of tho Taylor Bill in tho issuenco of poinj.ts and the fuld oporation of tho moasuro, but if you don't make cood, God holp you.

(Louihtor).

MR. CARPENTER: That sounds kind of liko $\therefore$ throst to no. (Leühtor). Any othor statos wish to expross thensolvos?

MR. JORGENSON OF UTAH: Portaining to this quostion of allotionts, I soe that wo hevo soeregatod in four classos a süiested basis for ranco allotmont: First, classos of livostock; soconi, sosson of uso; third, community or joint uso; nnd fourth, indiviclual uso. That is tho basis upon winich wo aro oxpoctod to disouss this measuro. The first question appoals to no as meanine, aro you ablo now to dotomino as botwoon shoop and cattlo what particular range they aro cntitled to.

I an of tho opinion that you aro not quite roady to detomino that in the becinnine. Kooj in mind I said in tho boginning I favor allotionts, but I don't think wo aro roady to detomine thet question tocay. I thorouch study of " tho ranco hes not yot boon made. You nro not able to say just which rango should bo oxolusive oattlo rango and wilch shoull bo shoci rango.

is to soason of uso, I tako it tho Bill itsolf infors, tho fict passod by Confress, that the prosont intent of the mossuro wes that wo should moko projor uso of the land in question, not only tho public land but the ranch lands that are to bo usod in conncotion vith the jublic lands.

Lot no call your attontion to the fact that here today you passce. a rosolution to tho offoot that you aro poine to consids second in ordor thoso vith cormonsurato property for pomit ri iht rojarcloss of whothor they fot prior uso or not. If thoy hevo bot ranch lends sujtablo for livestock puriposes, although they havo novor omod livestock in tho past, they n ro to bo considorod for a pemit. If class A applicants aro token caro oi -.. thoy may havo nll this land loased -- I tcko it to mon that proctically all tho linds of Utah aro lands that cro proporly in lino to bo considered in seourin an aiplicntion on tho julic domin to [razc livostock. I think that I enn soy without fecr of contradiction that $90 \%$ of thm privetely-omed lomis in itch could be considerod as proporly in lino for an aplicntion to ernzo livesteck upon the punlic lomin. If we con grant that as c. fact, thon you has a bif problon to tako into consicieration.

Wost of tho ronchers have boon compllod to loon theil livostock won their own promisos within their ovm corrals, but undor tho Tivin Grozing iat ca wo aro prococdine, ajarently ho is ju lino to oxpert a permit unon tho jublic donain. So I nn quostioning tho advisability of boinci roni to allotmont pormanont pernits at the presont tino. 
Iow you havo tho quostion also as to sossons.l usc. is I scite a momont neco, in iny estination ono-of the prime jurjusos of the j.10c.suro wis proper lane uso. In :hy min?, propor lan:! uso also moans proper seasonal use. Just whrt scason of the yoar shoulc it bo irented? Sholl it bo irnite? in the spring or chring; the sumer or vinter? Ifos sufficient stucly beon micle st this time to cotcr vino in c.l1 ceses whet is the proper uso to be mace of ecritain aross? Until it his, I thin! you nre not rondy to start out melkin: nllotmonts.

Then I nute by tho jrogran here we come to commuity or joint use. I an inclinoc to think, if wo are coing to rako allotnents, ir the berinnine it better be combunity or joint uso. On iost of these public comin arons ve find thet we have to dejend to a proat oxtent on moisture. It is mostly cosort areo I an ine jinod to beliovo. It mi ht be advisable in tho bojiming to rake joint allotmons, or communty allotmonts. I thint it vouls.

Portainine to incividunl use, I hnvo on idea it should be ouite a lone tino before we cone to that. Yet person.lly I believo I woul? be satisfied if I had an indivicunl allotinent. I an very doubtful that the advisory boards in tho. Mifforent cistricts have mace sufficient stucy to tcll then where to ro, yet they may bo classed as Class is crazine entitled to $\because 0$ to the district, entitled to recoive a pemit for tho district, but no one is ablo to tell then whore to Eo beccuse of insufficient study of the problem cinc not beinf taken into consideration to the extent that it shoulc? be teken into consideration, as to just the number of livestock it is exiected to frceze in einy ijiven area end how lonk.

Our Department of the Government is cheriod with the duty of bringing back into proper condition theso pullic doinain areas. I think a cooc part of our livostock-men will concede thet a lot of these arcas havo boen ovorciono. have killod out a lot of valuable forafe that previously frow on it. I taleo it that the bigcest part of you vill frant that this Dejartnent of Govemuent is charced rith the restoration of those barron areas. I an vory coubtiful as to whother sufficient stuciy has boen made of the area. If you have sufficiont inforration in this coinoction, I rant to say 00 ahear and malce your allotrents, but I voulc? aclvise that they be commity or (rou, allotmonts in the borinninc, dops.:.ng on what information you havo besoro you in malkini those al.

ini. CiLPENTFin: Gentlenen, I want to make a little explention. ie are telkinf about temporary allotments of raz;e. In re:nre? to our stucies in this matter, in some cistricts wo have a very ooc tye cover for comonsurate property studies. Tie are not tryint to mire a con icte fincinc; that will a hundred por cent porfect. Te are trying to brine tho benefits of the Taylor Lict to the poople who ere entitlec to it. I con't want to fool you members of the advisory boards. If this conferunce ceaded that temorary allotnents of some kind should be incorporated in any or wlil of the licensos issuod durine the yoar 1936, you have cut out a bi: jol for yoursolves. It is indeed an arduous job. It is not coine to be onsy.

IR. MiTHIS OF iRIZONi: Finen we started out, we followed the custowary way of Grazing and use of tho range. That is the thine: that tho Taylor Bill is trying to cet avay fros. lie elected boswis of sheep and cattlemen who bnow the country. Our board is ready to males these allotnents. I think the Dopartment is ready to accent the rocomonclations of theso acivicory boards who have mace a study of $i t$, have been raised in the business, and lnow how the alliotnonts should be rade at this time.

I think wo should faror allotrents for 1936. I think wo are back of this Taylor Bill one hundired per cent.

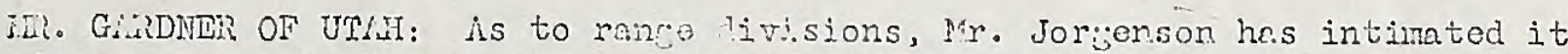
can't in a moasure be done. It rouid bo fooliah for the advitsory bonrds to fo back and tell tho fellows from their isotricts wo are foing to divire this ranice. On the other hand, if they cone ond say we wat a livision of the rance, both shoop and cattlo, if the division is outlined ve klow that there are peoplo who have more than enough cominensurete property but they are villinc; under the licenso period to be lenient. They vill protoct tho cattlemen and tho cattlemen will protoct the sheemen. T:o are not forcin: it on them. They aro presenting it to us and are anxious to have this division mado. They are preparine: for that, thoy are anxious for us to take a step as an advisory bonrd" to assort oursolvos. They say, "Thatover you say wo will stand behind you.". " 
We are bohind the the Taylor Bill in all that it means. We are ready to cooperato with those men. We don't have to $g 0$ and toll then we are goinis to male a division of tho range. Thoy aro maling their om divisions. They eloct their comittoos and assemble, three sheeprem and three eattlomen, and they will respoct those lines until such time as the grass can be sturied.

Mi. IURDOClK:OF UTAH: I have not heard much from Io. 3 , but I can say this, if these fentlemen that are on the advisory board in No. 3 are not able at the present tine to go and set this ground off and allot, at lcast in community allotments, they will never live long enough. I lmow men born and raised on the desert in No. 3. I know that these men lnow whore they want to go, and they blow that transient herds have drove the comnon and little grazier out of business. They lnow that.

Tie hare got men 65 years of ago on the board. They lenow what has bocome of southern and western Beaver County and western ifilard County. They lenow that intorstate herds has crove those people to povorty. There is no question about it. I have lived in Beaver County the biciser part of ny life. inen I first went in there you could see herds of cattlo oil the domain. Today we have got a poverty stricken county from one end to the other. Vihy? simply because they were drivon out with big travelling herds. I think we are ready for the question.

IT. LUBICEN OF CiLIFOUIIA: I believe that that should be left up to the various distriots of the states for the simple reason that I bolieve the Mojave District can arrange their wholo setmup botreon the shoepmen and cattlemen. he have practically got that settled right now and did it last spring. I.e had an arroement between ourselves tha't different sections vero allotted to different individuals. I con't nean that each individual had a certain section, but possibly three or four would be permitted in one/ seetion of the range.

It is true we orerlappod, but I believe the only way to cet at this is to loave it up to the districts thenselves in each stato. That is the only way you can get to it.

(Aipplause).

I an sure we have got our Moja've District praetically settled, and the only ones that will discord with us are those that don't orm a foot of land. lie can start from the upper end of the district and co clean to the other end, and the sare cast and west, and I believo we are all rcady to make our various allotmen's, althourh I admit that there mitht be throe or four permittees in each allotment. I am in favor of tho various districts talsine it up in thenselves.

MR. WHINISRY OF COLOWDO: Spealcing for District 3 , I beliove we are just as ready. now as we vill ever be to balo up tine question of fiving term pernits -those term permits for Class i should be for 10 -year periods - and also to make these allotments. The big end of the allotnonts in District $\Lambda$, in my opinion, vrill be eomunity allotments, as the chaimnais pretty well knows that section. He knows that we have to use it coljoctively.

The division of the range as betwoen the two classes of tre industry, the cattle and sheep, is practically alreacy mado and agreed to. Te have on our board, if you please ifr. Carpenter, and you know that too, men who have had years of experience in operation in our district, nen who know the different sections, in which they live, like a book. Thoy havo ridden over it for years. I believe our board can conolude this work by November lst of this year in the pormit and allotment section. We also can give temporary area pemits to the other elass that aro entilled to that.

Mil. LUBIEN OR CLIFORIIA: I want to move that we put this mattor up to the sections of each stato and lot then make tho docision.

MiT. CMRPENTER: Wie did not expoct to vote on ther. It is just a topic I wanted to run ovor. You can' consider it further in your caucus this evening. Mr. Whinnery touched on a matter. Boforo this meeting is turned over to the sections 14 and 15 meetine in 15 minutes; I want to jump sub-section 5 on page ${ }^{\prime \prime}$ 3 , bemporarily, and 60 dom to section 6 and $I$ will read it to you. 
"If the issuance of temporary tem permits is to ve on the basis of dependent property without consideration of prior uso, how soon is their issuance advisablo?"i I can't let this assombly go into the state neeting without calling attention to the fact that there is nothing nentioned in the Taylor lict about prior use that I lanow of, that when term permits aro issued under section 3 of the lict they will fo for the dependent comnensurate property, land and water, and all, that wo are doing is findinf out how many steps wo want to take to cot up to that point. That nust be correctly understood. This matter of a rance allotment is one step in that direction. This matter of a classification of dependent properitios is anothor step in that direction. The subject, just before this classifying commensurato properties, winich I am going into right away, is anotlier step in thet direction.

If you take all the steps a little at a time, when you come to the transitional period to 60 into tem permits, there will. be no great big jump for anybody. No one realizes better than you do how fast the peoplo are gotting their places ready to go jnto the division of the range. We should tell thom where to buy their properties, and we should tell them what properties are going to carry - ilose. rights, and then in anothor year you vill give them a chance to get right and get it. I realize if you delayed this thing fifty years thero would still bo pooplo who would not be ready. I have got a neighbor who is never ready to put in hay until aftor it rains. There is plenty of that goes on.

But this great body of men aro not going to vait until everybody is ready because the grcat majority want the bonefits as soon as they can get thom without any injustice to too many of us. So I rant you in your state caucus .although Mr. Thinnery is the only man who mentioned term permits -- I vant you to considor that, when we are worling toward term permits, wo vant to get people now in the business, and there are plenty of them to use all the range. If they can do that in two yoars, they have effected a wonderful adjustment to a wonderful statuto. It is that press for time that we are working for, to give time to the existinf industry to edjust to a law whieh cut counter to a use of the range which existed for fiftiy years.

I am not going to ppen question 6 up to discussion, but you can see what there is Inaded into that section. I want $120 \mathrm{w}$ to go back to Section 5 , and in the next few minutes lert to us, take up some of the matters contained in there. Section 5 on page 3. "Should commensurate property be divided into classes and definitely defined?" Now why should we do that? To kj the the board something to put their fingers on. The boards have had to wallow those applicatiens around in their mouth and did not lmow which wy to go. Vouldn't' you like to have something more definite? It is very vell to say, "Don't classify, don't define, don't be definito." That is the way to dodge, but the fair way is always the hardest, and we inight just as woll face these questions and get all we can in two days, to get all we can and definite rules to these boards because they are going to work this coming year as they nover did before.

If we can corne out of the year 1936 vith anywhere near as fair a division of the ranpo as they did the division of the liconses, they have done a marvelous job. That is ny excuso for esleinf your consideration of the division of commenisurato proportics.

Please glance at your papers and notice that I have suggested that in different districts certain properties should be marked as essential. $\Lambda$ man who hes not at least one of them could never get in vith the second class of comensurate properties. It would look as thourh some cultivated feed would be an essential comensurate property. Thore aro some districts where froncoina wator is just as essential as feed.

In frizona and New Mexico yoar-round water is just as ossontial as feed. Natei means as juch to ther as foed menns to us. That.is the second class of essential property. The third class is a new developmont suligested by the Taylor $i_{2} c t$, and I wish to say that one of the highest offieials in the Forest Sorvice, a man who has almost unlinited wisdom on rances and 35 years experience, said if he could go back ovor his life and do something he had left undone, he rould make protceted pasturo commensurate property, because whon 
that is done you aro putting a promium on a man who saves his foed and protects his range. If you care to make protected pasturc an essential comensurcte property, you put a premium on it and you get men protecting their pasturo and buildins back their range, and you are coming back to the time when the vistern livestock industry is prosperous instead of "hang on by the teeth industry".

I also suggested special facilities for the protection of the livestock. I am not sure whethor they should be essential. Possibly they. should come dow in the other class. When a man has qualified in the district with either protected pasture, permanent water, or cultivated feed, if he has come in with one of thom, then he can add out his set-up with pasture lands with purchased foes and with temporary water.

I want to know, and I hope you will consider in your state mectings tonight: Is it advisable at this time to sub-divide comnensurate proporties? Man after man hes come to, me and said, "Why don't you tell me exactly what it is I can buy and where to buy it?' You won't tell lio. There is one fellow fots the range because he has a haystack." Ve have done everything to take cisso of these people. We heve had a your to think abrut it.

If you want to classify this thing, it is going to bo necossary to get in stop and 50 along. Look those over - they are only suggestions - - and whon you come back tomorrow we ere goine to call for a roport from each state, and we are going to ask the opinion of the states on the division of dependent propertios by miles. We are coing to ask for the division of commonsurate properties, .. . We are going to ask their stand on allotinents of rango. Then we are going to asle them as to the matters of foes. Those four great topics will have to be covored tomorrow moming.

After tho State reports are recoived, after genoral debate is over, then we are going to vote -- if thore is a call for division, and these accredited delerates will vote and they will vote per man right straight through, and the vote will be recordod. The mornin session will be devoted to that.

Tomorrow afternoon we will go to tho two last topics, which are organization and improvement. Vo are asking a nusiser of the disirict advisors on the matter of improvement. No talk over five minutes. Ee will tako up the matter of further organization, we will take up the mattor of improvement, and there will be selected speakers, and we will try and finish our afternoon session.

At this time I will ask all of those who have not passed their cards in, to, do so.

I am going to ask if $\mathrm{Mr}$. Jevrett of the Biologjcal survey is here, if he will please meet with the Oregon commitiee, wherover their headquarters may be, as they have a gome refuge problon to tale up with him.

- Now I am going to ask where the statc committees want to caucus. ( $\Lambda$ t this point announcements were made by the chaimnen of each. State comnitteo as to place and time of caucus). .

(The meeting adjourned at 4:30 $\mathrm{P}$. M. , to resume the following morning.). 


\section{SECOIND DAY}

Niorning Session

(Meeting called to order by Direotor F. R. Carpenter, at 9:20 A.Mo, Jau uary 14, 1935, in the Lafayetto Ballroom, Hotel Utah, Salt Lake City, Utah.)

MR. CARPENTER: It is twenty minutes beyond the time that was stated on the program to open, but on account of our delay in opening yesterday, there has been some confusion. I realize that many of you were up late last night and this may be a fairly early hour.

This conference if successful, is going to be ropeated. It is going to be successful if we get something out of it that moves us along a littie on tho road. If it just leaves us, when we leave, where we carie in, it is not going to be successful.

We have had this mecting open to rather freo dobate. All comors/have been invited to expross themselves. The advisors have had the benefit of very many and divergent points of viow. We caucused last night by states, and I thought it would be fair to have in full beforo all tho delogates the resolutions of the ten states. For that reason, I will begin alphabetically and call on the state. chairmen to give the resolutions of their states. Whon we are thru wo will talse up a discussion of the mattor. I an going to ask cach state ohairman to get up on the platform and use the "mike".

(Short recess while the microphono is boing connected.)

Gentlemen, I notice the "mike" is working, and I am going to ask tho speakers to como up in back of the "raike" in orcer that you can all hear them. Before calling for the report of tho state chairmon, I will ask Mr. Territt to come forward. Mr. Territt is the man who has been selected as the new Assistant Director of Grazing.

- MR. JULIAN TERRITT: Thank you, lir. Carpenter. Mr. Secretary, friends, and membors of tho livestock fraternity: I am very happy to stand here this morning In this position. Any pleasure that I may foel by reason of that fact does not render me insensible to the responsibilitios which I am assuming. In performing my duties, it shall be my aim to be guided by the grazing law ond the purposes set forth in the grazing law, as outlined in tine preamble of the Taylor Grazing Act. I have always been greatly intorostod in tho administration of the public domain. When I was a child, my mother used to take me out to grazo, and I have always been, over since, greatly interested in the preservation and protection of an aclequate grass supply.

I might say that, if it had not been for a slip on the part of an eminent United States senator, who is now gone, Mr. Byron Wilson of Wyoming and I might have been the fathers of a good share of the Taylor Grazing sot. In ordor to keep from placing $M r$. Tiflson in bad with his good friends from Wyoming, I hasten to say that I rofer to that part of the Taylor Grazing Act which has to do with sale of isolated tracts and leasing.

I am remindod of the story of the man from Johnstown. You all havo heard "of the Johnstown flood in Penusylvania. One of the men dromed in that flood, whan he got up to Heaven, ho was so impressed with tho vastnoss of the flood that', whenover he oould get an audienco together, he would olimb up on one of the golden lamp-posts and begin to tell them about the flood. One day, ho had a big crowd around him and procoeded to tell them about the Jolunstown flood, when an old man with whiskers almost to the floor cume up, and looked at him and said, "Got down from thore and let mo get up there." This man frgh Johnstown said, "Who are you?" The old man said, "I'm Noah." 


\section{(Laughter.)}

I don't want you to feel that I havo the attitude of the mn from Johnstown, noithor that I f'ccl that I am a loah, but, by strict attention to work, study, and with your assistanco, I hopo to bo ablo to accorplish something for tho common good, circumscribod only by the limits of tho law, faimoss to the citizonship of tho country at largo, and that utmost loyalty which comon doundy domands that I rendor to the Socretary and my chief, Mr. Carponter; I shall always lend a sympathotic car to the probloms of the stockman.

I can say this becauso I was born and raisod a stockman, and I think that the people in the wost have noro interost in the administration of this fict than all the rest of the country put togother. I liko to fecl that there is a certain faith which is kopt by all true stochnon. If, when I nm callud lipon to sivo on accounting of my stcwardship, I can truly say I havo kept tho faith, then and only thon shall I feel that I have succoedod in some rcasonable degree.

\section{(Applause.)}

MR. CARPENTER: At this timo, wo will call for the report of tho strite committoes, beginning with Arizonn. I will ask tho chairman to stop up to tho platform, if he will, take his position back of the "mike" and deliver it thero.

IR. MATHIS FROM ARIZONA: I think, after my Introduction to this audionoo by Mr. Carpenter yesterday, you will decido that I an not an orator. Io introduced me as a "wild rider."

MR. CARPENTER: Well, ho swings a protty easy ropo, I'll say that for him.

MR. MATHIS: I didn't havo my wits about me quick onough to say that ho is the only man I know that I havo nut competod with in this yet.

I expected this to bo conducted a little differontly than the way we have started, so I havo not preparod anythine very formal hore in tho way of introducing rosolutions. Wo have just gone dovm the list of questions and have made a notation oppositc each ono, and I am trusting to my memory to oxplain the attitude of the Board on each of theso questions. We discussed somo yesterday as to the meaning of "contiguous". We dccided in our reeting that we would define contiguous in our district -. I would like to say, however, beforo I go on further, that all of the delegates from tho state of Arizona met with us and partioipated in our deliberations, gave us their ideas, which were vory fine and good, but the No. I distriot, which constitutes tho Arizona Strip on this sido of the River, is the only district that hes so far beon created in Arizona, so in our votes wo only represent tho Strip.

The question, "Should cuts within a class be mad on the numbers of livostock of by restriction of the senson of use"? We decidod this quiostion could only be handlod right and proper by the Advisory Boards; and it should bo elastic enough that wo could handle each individual case as tho conditions would call for.

"Should temporary allocations bo incorporated in all 1936 liconses?" To this we answorod yes. Wo expect thore will be some argument against this but wo dooided this thing may as well be docided now. We may make some mistokos, may havo to retraco, but the thing may as well be started. The Advisory Boards will change from time to tine in porsonnel, and I think tho Boards that have studied this for the past year aro about as well prepared now as they will be later on.

"Should comonsurate property be divicied into classes and definitely dofined?" Definitely dofinod, this division bejing contingent upen the rargo panagement protioo obtrining in locnlitios. This is also a study for tho advisory boards to rocommend to the Departriont. I Inve seon timos whon I could not read my owm writing, and I didn't think I wolli? hnvo to do it so much todoy.

"If the issuanco of preferential tarm pormits under section 3 of the Taylor Act is to be on tho basis of dopentont comensurate proporty without considoration of prior use, how soon is their issunce ndvicablo?" Wo rocomend that wo 
do not issuo theso liconses and pormits bofore 1937, giving us anothor yoar in which to work this out.

"The noed of special rules for fair rango practico, and tho onforcemont of all milos and regulations." Wo favor special rulos and rogulations, and wo rocommend that they bo onforoed. Those rulos and rocomendations should bo workod out by the advisory board. I will say for District I of Arizona, wo havel worked out, some rulos, and rogulations.

"Should any foe bo paid for tomporary liconsos?" We focl wo want to pay for all we get. Wo want to help pay tho oxpense of gotting this into working shapo. Wo roolize that, for a period, wo won't got much benefit out of this, but tho otponse will have to bo mot. Wo favor paying of liconsos as sot out and recommended by tho Dopartment, but we want to go on record as asking Congress to amend this law that wo will orly be ascessod for tho operating of this Tayior Bill in our district. Wo feel that wo are taxed now to all tho livostook industry can stand and, when this is set up, wo expect to be assossod only for tho oporating exponsos,

MR. VICTOR CHRISTENSEN OF CHLIFORNIh: Indies and gontlemon: Our comittoo worked quite lato in tho nicht to try to orrivo at what was bost for California. Wo did not agree unanimously on $a l l$ of the things wo aro offoring here today, for the reason that, in our two districts in Californio, thoro is as groat a difforence in usos anc oustorns as there is possibly in any state in the union.

We have District 1 in Califomid, where tho use is on a dosert sct-up, a dosert condition. Our District 2 in northoastern California, tho rango use in most cases is attachod to ranch property noar or adjacont to public lands: : So, though our rocommendations woro not always unknirous, wo did attempt to make recommondations for tho best interests of tho people who represont both districts.

First, as to the question of foes: California representatives approvo of a reasonable feo whon the districts aro rondy for term pormits. Tho lodoc-Lassen district, District No. 2 in California, still boing in tho procoss of detcrminotion of rights, askod that thero bo no foos for that district for 3936. Distrist No. I of California approvod a foo of ore cent per month on shoop and fivo cont's per month on cattle, whonever term pormits aro issued and protection furnishod.

Also, we wero unanimous in ondenvoring to carry on an nctilvity whereby the Taylor set could bo amonded so the charge for foes would be that which was necessary for the administration of the Taylor Lct only and not have it as a taxcollocting agoncy.

As to changing the order of proferontial classes for licenses: California representatives approve the plan of order as outlincd by the Dopartment for 1936 and approved by tho grazing assembly Januery 13, 1936. As to dividing dependont propertios into two classes, as follows: ( $($ ) Thoso within or contiguous to a district. - Colifornia reprosontatives asked to loave the vord contiguous out and include or replace by the word "ncar". (b) Othor proporties that have beon or oan be used in connection with the publio lands of a district.

No. 3. Should cuts be made on tho numbers of livostock or by restriction, of the scason of usc? California recommended cut in timo or season of use rather than cut in numbors. No. 4. Should temporary a.llocation of rango be incorpow ratcd in a.l1 1936 liconses? California rocomnendod that allocation of raneo be mado in as many liconses as possiblo to fairly allot rongos in 1936 by the Advisory Boards. No. 5. Should comensurnto property be divided into classos and definitoly dofincd? Yos, somo should be done as definitely as possible ane at as oorly a dato as possiblo to do so correctly. No. 6 - If the issuance of preforontial tom pormits undor soc. 3 of tho Trylor Act is to be on the basis of dopondont commonsurate proporty without considoration of prior uso, how soon is their issuanco adrisable? Torm permitis aro oxly advisablo whon the propor information has beon obtainod so tom pormits con bo justly givon or approved. No. 7 - the nocd for spocinl rulos for foir ronge practico, and tho onforcomont of all rulos and rogulations. Cnlifornia roprosentativos soo tho nood of spocinl rulos and rogulations and ask for tho approval and cnforcomont of spocial rulos to be suggestod for 1930 usc. 
Even though we are on a liconso basis in 1936, wo hope to have spooial regulations approved by $\mathrm{Mr}$. Carponter and the Sccretary, and that they bo in forco in 1936. Our mombors of advisory boards in califorila aro proparing to tako up al 1 the problems that may bo boforo us this Narch, possibly the lattor part of Fabruary, and we hope to have spocial rules and rogulations that will bencfit our noi ghborhood.

Is to organization, corporations aro rocomondod for district associations dosiring same. That was quite a big quostion, and wo did not go into it vory deoply. It is going to tako a great deal of study, but we know, in our district in northorn california, wo aro vory much in neod of somo surt of corporation sotup in addition to our Division of Grazing and our acvisory bnarl work, for tho purpose of leasing Indian lands, schocl lands, and other stato lands which aro intermingled with tho range aroas, and which, in past yoars, oporators who aro bothered by tromps on some part of these lands, much to the detrinont of the pooplo who should have the proper use of the range. Wo hope to have an agency that will help us properly loaso, distribute and cherge for thoso lanes.

California approves the ECW work proeram attached to the Division of Grazing for the benefit of the livestock industry. Wo rocomiond the continuation and oxtonsion of that service and promise our cooperation townds its success.

It the present timo, we have threc EcW carips in our stato, onc in tho southorm part of the state and two in the northern part of tho stoto, and it is romarkablo how much bonefit we are gotting from those carps and the gooc work thoy are doing. The boys are all Eastom boys. If any of you gentlomeil havo tho possibility of gotting an ECW camp in your noighborhood, you wait to recormend it.

For some reason, thore sooms to be a distinct slang; in the persoinol of the CCC boys. A fow years ago, wo hud one ECW curn cono in which whs not attrohed to tho Dirision of Grazing, and thore woro quito a group of ronogato boys in it, whioh disturbed the little communitics. But now the boys we havo in our cimmnity aro just os fine boys as you could find anyirere -. not only a crodit to the CCC activitios but also to tho homes from which thoy cano.

We havo one further rosolution: "The California dologation are in fatror of tho Trylor Grazing sct as it hos beon oxplained to us by Diroctor Carperter. We will continue to support the Trylor Grazing lot as long os the democratic psinciplo of homo rulo for cach of the grazing districts is grantol tho grazing district advisory boards by the Division of Grazing."

\section{(Applause.)}

MR. BRAY OF COLOR $L D O$ : Mr. Pitchforth asirod me to go to bat for him, which I was very happy to do. It tho outsot, wo want it distinnlly undorstood thrt the Colorado delegation desires to cooporate with the Departments of the Intorior and the Division of Grazing in any mattor of finance, and not only an the ratter of financo but also in the administration of the district.

Tho Colorado delogation net at the hotol last ovening at $7: 30$. Tho entiro delogation was prosont. The first thing that onrin up was tho division of denondont proporty into two classes. You remembor that came up on tho floos yesterday and we had somo discussion about it. It was movod, soconded and carriod that rhe Colorado delegation oppose putting thoso permittoes in Class B whose commonsurnte property lios without a district. I might male just a small explanation of that stand. In Coluraclo, wo have, ospocinlly shoepmen, who hovo had their property thoro for as high as 25 and 30 yoars. It has always bcen thoir custom to trail into Utah to the dosert to winter. Low, if thoso people aro put in Class B, I would like to ask you what you are going to do with all thoso shocpmen. They aro logitimate sheepmon; thcy are not tramps. ' They havo commensurato property and lots of it. 
Question: Should cuts within a class be male on the numbers of livestock or by restriction of the season of use? Answor: Movod, secondod and carriod that tho colorado dolegation go on rooord that outs within a class bo laft with tho local board. Everything that we could not dooido to answer "yos" or "no", wo passod tho buck to the local board. The local boord needs some authority and, as I understand our delogation, wo aro in favor of giving thom authority, and thoy aro not going to dodgo it.

No. 4. Should temporary allocations of rango bo inoorporated in 0111936 liconses: Hoved, socondod and carried that Colorado delegation favor the advisory boards to mako tho nocossnry allocations and that they rocommend temporary allocations until such time as term permits can be issued.

No. 5. Should comensurate property bo dividod into classos and definitely defined? The Colorado delegation reoomond that property be divided into olasses and definitely dofined, but that Item D, narely: "Special faoilities for protootion of livestock", be ploood under Iton $C$ in the following paragraph.

No. 6. If tho issuando of preferential term permits under soction 3 of the Taylor Aot is to bo on the basis of dopendont comicnsurato proporty without oonsidoration of prior use, how soon is their issuanoo alvisablo? Tho colorado dologation fators the issuanoo of proforential term pormits on a basis of commonsurability, dopendability, and priority, as at prosont, and that it be left under tho oontrol of tho local board. You see, we koop throwing it of $f$ onto the local board.

Question: Should any fec be paid for temporary licenso? I an just going to read tho answer, and then tho remarks I male afterward will be entirely on my owm. "Tho Colorado delegation is in favor of paying not to exceod ten cents per head por month for cattlo and two conts por hood por month for sheop, providing that torm permits be issuod if and whon fees aro paid." In this connoction, I might say that the colorado delogation probably wore not unanirious on that, but the feeling among the Colorado stocknon is this, that if you will leavo the administration of the Taylor lict in tho wost arnong tho coloracio stockmen, and the Utah stockmon, and tho othor wostorn statos, wo are willing to as sumo tho full rom sponsibility of paying the ontiro cost of administration.

\section{(Applouse.)}

MR. WORTH LEE OF IDAHO: Mr. Chairman, Mr. Secretary, ladies and gontlomen: I might say that those recomendations were the rcoonumdations from all of the users of the public domain from tho stato of Ilaho that woro horo prosent at Salt Lake and they woro made with the undorstanding that thcy would be in no way prejudioial to any latitudo which might bo givon to the local boards of each district. Wo roalizod tinat all the latitude possible, and all the considoration possible, that the Taylor Bill would allow, should be given and considerod, from the rocommendations of the local board, as it studied tho qualifications and the classification of each pormittee on cach applicarion for a pormit. I might say that wo worked long and diligently, and discussed this in evory monnor possiblo, and wo could have spent a longor timo on occh ono of them, but those are the recommendations that we finally arrivod at, as fin as we were able to get down tho line:

Grazing feos: Resolved by the stockmen of Icaho that no foos bo required to be paid under the Taylor Grazing nct until the stockmon aro issued permanont pormits.

No. 2. Policios: Rosolvod and roommended by tho stockmon of Idaho that, where a man bo dotermined as a Class $A$ applicant undor subclivision $A$ of Soction $I$ of Policies that suoh right bo rooognized in contiguous or adjacont districts, it having boen specifically undorstood that district boundarios and stato lines would not joopardizo tho customary use of tho range. 
No. 3 in rogard to "Cuts". Resolved by the stoclmen of Idaho that if any cuts aro to bo mado that thoy bo mado by animal days instead of any cut in, numbers. If a man had an economical unit, where he could run a certain number of shoop, and docided that his ranch was too small, that, in ploco of cutting, his number for that year, that he bo notifiod that ho could buy a littlo pasture or somothing, and still reserve the right to koep his full quota, an oconomical unit.

No. 5. Divide commensurate proporty into classes. Resolved by the stocknen of Idaho that no action be taken on the division of comonsurate proporty into classos at this time. Now, I will say that wo talked this over at length, and finally reconuronded to tho stoclanen that no action bo taken on the division of commensurato property into classos at this time. I vill say that District I had already set up rulos that they had rocomiended to tho socrotary of the Interior that wero just about as noar fair as we could decide on for the district ij Idaho that had becn set up. Of $\operatorname{cours} \theta$, wo have users in the othor two districts, in contomplation that had as much to say about this as tho district that was set up.

No. 7. Noed. of spocial rulos. Resolvod that the question of need of spocial rulos cor fair range practicc, and the enforcement of all rules and rogulations be unanimously passod at this time without action. Wo did not have much of a set-up in Idaho and wo did not roally know just what kind of rulcs wo wanted. It was getting lats at that tirie and tho boys were getting ready to seek a little refreshnont at that time, or rost thimsolvos, just whatever you want to all 1 it, and we passed it up.

Arganization. Rosolved by the stookmen bi Idaho that we are not woll onough posted at this timo to make any rosolutions on organization at this timo.

Improvoments. Resolved by tho stoolmon of Idaho that we are not well enough posted at this timo to make any rosolutions dimprovements at this time.

But we did, as will bo shown lator, we appreoiated tho CCC camps and reaijzod the wondorful assistanco they could be in improvenent of tho range and, if wo had a term poriod of yoars that wo lnew wo could depend on thom to mako the projeots and start them out on the work.

That concluded all the questions that we had passed on and, under this new business, I will read tho resolutions and explain it if it is not cloar to you.

VOICE: I think you neglested to state our position on No. 6 on Pago 3.

2B. IEE: I beg your pardon. No. 6. Issuance of term pormits. I overlookod that and, by the way, it was ono that carried a great cleal of discussion and I am very glad you called my attention to that. We discussod this long and faithfully and, afier wo finishod, this was our conclusion: Rosolved by the stoclamen of Idaho that it is our judgment that permits should never be issued without consideration of prior uso. Now, the point that we wore trying to get. at, I gather from the discussion thero, was this, that wo felt that our personal proporty and our real estate already was standing about all the taxes that it could pay; in fact, in Idalio, it tales a pretty good business man to borrow enough money to pay his taxes, and wo wanted it brought down to this fact, that any oxtra assossment or fees of any kind that could be assessed against tho stockmon on the public domain, should be only as much as it would acturlly use" for thoir part of tho administration or policing of the public domain.

Now, you Eentlemen from Idaho, if I have overlnekod anything, call my attention to it. I believo that is tho exticnt of our resolutions.

MR. ChRPENAER: It is evidont, from tho attention and chocling beins made on this, that no ono, not oven the chaiman, is going, to skip anything.

MR. MATHIS OF ARIZONL: I havo beon remindul, since I took ny seat, that I overlooked siving tho room my definition of "conti grous".

IR. ChRPENTER: I am glad your conscicnce warked. You can givo it now. 
MR. MATHIS: District No. 1 of $\mathrm{Mriz}$ ona and District 4 of Utah, their interests overlap so that wo had somo eonsiderablo discussion as to defining what "eontiguous" might bo ealled in terms of distance. We decided that Iron, Kano, and Washington countios will. be eounted as contiguous to the district, or adjoining countios to tho district will be eounted as eontiguous to the distriet.

MR. CARPENTER: Thank you, Mr. Wathis, That is tho first definition of "fringe" that I have ever hoard attompted. We are GCing to have to define it sorie day; I guoss we might as woll start now. I am glad to soo the Arizona Strip hid the nerve to toieklo it.

MR. J. M. JONES OF OREGON: I an not going to attempt to give you my ideas nr the ideas of a lot of tho representatives from oregon, but $I$ am just going to briefly road what wo did. I think thero are two words that most all of us like to hear in practically overy epeech that is made before very many plibliel gatherings, and that is: "In closine." So I will use this as "in elosing." I havo not got the questions, but you aro all familiar with them now, so I vill just road the answors to the questions.

Oregon delegates to the Taylor Aet Grazing Conforonce, following the oponing session of the eonference today, made tho following reeommondations, whieh will bo prosented to all delegateo tomorrows

That a grazing foo for 1936 bo fixed at 2 cents por month per head for cattle and horses and one fifth of that amount for sheep.

That the definition of the terms "eontiguous" or "near" be left to tho Advisory Board in oneh individual onso and set-up.

That local Boards bo permittod to detormine whother euts of stook or time should be mado in oach individual permit.

That the question of allotmonts should be left to tho loeal boards, with permission to deeide whon the allotment should be mide and whether they should be individual or group.

That cultivatod feod, permanent wator and proteeted pasture be eonsidered as commensurato property, togethor with other pasture whon used in connection with a permanent setrup.

That long-term permits bo issuod as soon ae possible.

MR. TERRITT OF MONTLNA: Wo, tho reprosentatives of the advisory boards of the grazing districts of Montana, attonding the conference in Salt Lake, mako tho following recommondation. I want to say here that these rocommenclations were unaninous in every cose. There whs no dissenting vote on any of the propositions.

We, the representatives of Advisory Boards of the Grazing $D_{i}$ stricts of Montana attending the oonferenoe in. Salt Lak o City mako the following recommondations.

1. Grazing Feos. (a) We roomend that a reasonable fee to cover administrative costs should be paid for the 1936 temporary lieense whore ranco allocations are mado.

(b) Wo foel that not to exeeed one oont per hoad por month for sheep, fivo cents for cattle, and soven and one-half cents for horses is a reasonable fee to be assossed in proportion to tho percentage of publio comain ineluded in tho area.

I might say the Montana delogation tako the position that thoy aro porfectly willing to pay their way. Thoy don't vant to pay more than tho eost of administration, because they feel that their taxes are already so high that no additional burden should bo imposed;

No. 2. : Division of depondent propertios into classes. Wo feol that this ia a question to be left to the discrotion of the individual advisory boards. 
No. 3. Should outs within a class be made on the numbers of livestook or by restriction of tho soason of use? We submit that this question is purely a local one and therefore it should bo left to the discrotion of tho various Advisory Boards.

No. 4. Should temporary allooations of range be incorporated in all 1936 licenses? (a) Wo are in favor of temporary allocation. (b) We rocommend that the basis of allocations be left to the disoretion of the Advisory Boards.

No. 5. Should oommensurate property be dividod into classos and definitcly dofined? We consider this question is purely a local problem and therefore rocomond its solution be left to the discretion of tho various Advisory Boards.

No. 6. Issuanoe of preferential term permits. We recommend that no term permits be issuod until such tino as tho carrying capacity of the dependent commonsurate property bo determined and a forage survoy of the publio lands is made in arder to determine their carrying oapaoity.

I want to add just this, that tho members of the advisory boards of Montana aro willing to aocept all tho responsibility placed upon thom, and they fool that tho only way to sucoossfully administer the Taylor Grazing Act is to place adequate authority in the local advisory board.

MR. OLIVER LEE OF NEW MEXICO: I fear that you will feel that New Mexico is making a yery briof report on this questionnaire. Now Moxico has, from the beginning, endorsed the Taylor Grazing Aot. New Mexico has, from tho boginning endorsed the program devisod by tho Depertmont of tho Interior and brought to us by Nr. Carpenter. Now Mexico has bcon in such full acoord with that program and with $\mathrm{Mr}$. Carpenter's ideals and idoas of propor administration for the public doman that we feol it is unnocessary olmost for us to state our position on any of those questions, beoause they are already woll known.

Further, I think one reas on for our briefness is that we expeotod that, possibly, wo would just answer "yes" or "no" to the various questions in tho program. But, to bo a little more spooifia, I will take up just a fow of tho difforent. questions and state our position.

Ono of the first questions I como to on the program: Should any fee bo paid for temporary license. The answor to that is "yes" provided that tomporary or permanont allotments of range are tiod to tho fee. $\Lambda$ s to the amount of the feo, the attitude, I think, of not only the delegation from New Mexioo, but the attitude of o.ll the users will be. I think, so far as the users of tho public domain in New Mexico are ooncerned, that, as the Socrctary of the Intorior has beon kind. enough to suggest to us a feo that might be accoptablo to the Department, that we feel we should moet him on that quostion.

If I remember oorreotly, tho foe suggested by Mr. Walters, Assistant Socrotary, was one oent per hoad per month for shoep and fivo conts por head per month for cattlo and horses. I think that fee is accoptable to Now Mexico. It certainly is to the New Moxioo delogation ropresonting the different grazing districts that are here, and, in passing. I inight say that it has boon tho oxooption at any meoting that we have held in New Moxioo that there was any differoneo of opinion - any serious differenee of opinton.

In New Mexioo, the livestock raisers -- you will pardon mo for saying Now Mexico, because I really mean the livestook raisers in New Moxioo $\rightarrow$ both shoopmen and oattle mon have alwnys been usanimous, or approximately unanimous in their recommendations on all of theso different questions, and the reoommendations that I om offering you hore today are unanimous as far as the Now Mexioo delegation is conoorned.

Wo havo this quostion, which I beliovo has rathor confused some of the othor boards, whioh fives oonsiderable concorn, and that is this question: "If the issuance of proferential torm permits under Seotion 3 of the Taylor $\Lambda$ ct is to ide on the basis of dopondent oommensurato proporty without consideration of prior uso, how soon is their issuanoe advisablo?" We felt that any answer we mado would bo the wrong answer, beoause the question is prodioatod on something that we feel 
is not oquitable. I don't think you oan rot an equitable adjustment of the use of tho public domain without you consider prioritios.

\section{(spplaus ..)}

Wo admit possibly that it is not written into tho law, but I feel that the intent of the law carried that. Our dolegation dooided that wo. would not attempt to make a reoomondation at this time, that on that quostion we would pass.

Further, it was the opinion and reommondation of our delocation that some means should be provided by which on assessment oould be logally made for districts in our state, that the revonuo so derivod from that assossmontshould gO into the local treasury of the respeotivo distriots to be disbursod by the looal boards in thoir disoretion for the necossary policine, improvemont and care of the grazing distriot, relioving tho dopartment of that amount of expenso.

In conolusion, I would Iike to say that the New Mexioo delegation is in full acoord with the efforts of Nir. Carpenter to brine about the proper use of the publio domain. I think you.

IR. WILIIAM WRIGHT OF NEVIDAs I wish to profaoo my remarks with a statement that I am not a momber of any advisory board. The stato of Nevacla is ratior generally represented at this conferonoo by mon who are on advisory boards, by mon who are in aroas hoping lator to oomo into distriots, and by men who havo proferrod to romain wild.

I have beon honored and priviloged to act as towporary ohnirman with the thought, I believe, that all oomors would be roprosonted. First, I vould like to state that Novadofondorses the stand which has beon taken horo relative to amending the hot having feos not go beyond the cost of administration. Soond, I should Iike to olarify Nevada's position rolative to foes.

The discussion horo yosterclay was very intorosting, and it was ovident to tho' Novada delegation that many folt Nevada was trying to bot something for nothing, which of oourse pours water on tho wheel of the eastern consorvationi"sts who havo always maintoi nod the wostern stoolmon woro getting somothing for nothing. Wo in Nevada wish not to bo in the gratuity class. Wo never have been. We have always paid for our range and wo intend to koop on paying for it. But wo have, involved thore, a very sorious problem.

When you stop to oonsider that, of the entire area of the State of Nevada, only ten porcent, or a little over, is privately omed land, fifty percont of the ten percent, one half of the ten porcent, is ownod by the railronds. This ton pereont, owmed by the railroads and private interests, shoulcers the ontire tax burden of tho State of Nevada. Thru tho indireot proooss of carrying those taxes and the intorest upon owning strategio land holdings to oontrol the range, stratogic water holes, "wo have paid daarly to control our, grass..

This is brought out on the oost studies of grass per oow unit, and I dofy anyone, oven those who maintain wo are gotting somothing for nothing, to broak down this position, and feos, thereforo, for us, must be componsated for in a roadjustment of the tax struoture, which is now carrying the entire stato, almost 80 percent of whioh is to como under foderal regulation.

In Nevada, wo aro not quite as quiok in the head as we might bo, and we were given a rather hoavy order to digost, analyzo and erystallizo thoughts to go on reoord conoorning the various polioios that have beon prosented to us. Wo were unable to do it -- porhaps wo will be olassod as thoso in the draf of the herd -but, rather than take the risk of joopardizing tho welfaro of our livostook industry, the basio industry of our state, wo havo proferred to proooed onutiously, and, in one brief resolution, we havo covered our stand: 
We, tho Novada delegation, resolvo that thore should be no foo during tho temporary lioense period, until such time as pormits are issuod, and that all mattors brought up horo, suoh as tho ohanging of Classos. 1, 2 and 3 in Circular 2, should bo left to tho looal boards, as well as the determination of tho amount of foos.

I wish, in conolusion, to stato that the Nevada stockmon arc vory Elad to cooperato with the Division of Grazing in an effort to work out this vory far-." roaching problom. Our only oonoom is our vory existono, our vory lifo in tho range businoss. Thank you.

\section{(Applauso.)}

NR. J. L. NIELSAN OF UTAH: I brought my socretary along for several rensons. This is the first time I evor stood beforo a microphono, and, in caso I might fol 1 dead, ho could go on with the report. Anil anothor tling, I brought him al on: for is, aftor looking at tho ohairman, you might get a wrong improssion of tho Utah dologation, so I brought ono good-looking man along.

Dologates of Utah met last night and invited all tho graziors in tho stato to meot with us. Wo askod thom to discuss the various probloms that wo wero givon to disouss, and that lastod about two hours. Thon wo nskod them to wi.thdraw, and tho delcgation voted on tho difforont propositions. Wo might stato wo consider it a very big job for us to handlo in such a short timo, and wo thought that soma aotion should be takon.

Wilo thoso doolaions aro promaturo, perhaps, and not thoroly difested, they are the vory bost we oould do unler tho conditions and timo givon. I will ask my socretary to road tho problom and quostion, and then I will givo tho pusition of the board. censes?

MR. FRANCIS: Under Finanoes: $\Lambda$. Should any fee bo paid for temporary lim

MR. NIELSON: Dooision: Until such time as distriots oommonco to oporate on a permit basis, finanoes shall bo termod as assosinents and rates prescribod by tho District Advisory Boards, the ontiro amount to bo cxpondod by $D_{i}$ strict savisory Boards in proparing Distriots for issuanoe of pormanont pornits.

That means that, whore a permittoo is Grazing in two districts, that those local assessmonts would bo prorated according to tho time he grazed thoro.

MR. FRANCIS: Quostion: If any feo should bo paid, what amount should it ho?

MR. NIELSON: Dooision: Whon and at such time as the districts commonco to opcrate on a pormit basis, financos shall be termed as feos, rates to bo $1 / 2$ cont por hoad por month for sheop and goats, and $2 \frac{1}{\mathrm{~s}}$ conts por head for month for cattle and horses, pro-ratod as follows: $25 \%$ to tho Fodoral Govornment; $25 \%$ roturnod to district advisory boards for rango dovolopmont within distriots; $50 \%$ to ho roturnod to countios.

Wo ondorsod the action taken by the Gonoral asscmbly on Nonday January 13 , approving the ohange in preforontial classos for liconses. on that subjoot, wo had our Iivolicst fight. I intoncled to say, in tho beginnine, that theso dooisions wore not unanimous in many casos, and, in this partioular ciso, wo had our big fight, being almost equally dividod, but the majority ruled acooring to this decision.

MR. FRANCIS: Quostion as to dividins dopendant proportios into two classos as follows: $\Lambda$. Thoso within or contiguous to a diatrict. B. Othor propertios that havo or con bo usod in connoction with the public lands of a district.

MR. NIELSON, Wo approvo dividing of dopondent propertios into two olnssos with tho provision that tho Distriot Advisory Boards be privilogod to classify and intorprot sub-divisions $(a)$ and (b), acoording to tho oonditions within thoir particular cistriots. 
$B-11$

MR. FRANCIS: Should outs within a class be made on the numbers of livestock or by restriction of the season of use?

MR. NIELSON: Cur deolsions are that this be left to tho discretien of tho District Advisory Boards.

MR. FRANCIS: Should temporary allooations of range be incorporated in all 1936 Iloenses?

MR. NIELSON: We amend Nc. 4 under "Policies" as follows: That temporary allooations of range be inoorporated as far as possible in 1936 licenses, basis for allotmont under sub-divisions $(a),(b),(c)$ and (d) to be determined by D1strict Advisory Boards.

MR. FRANCIS: Should commensurate property be divided into olasses and cefinitely defined?

MR. NIELSON: We approve division of commensurate property into classes, definitely defined. Division and classifioation shall be determined by District Advisory Boards.

MR./FRANCIS: If the issuance of preferential term permits under Section 3 of the Taylor Aot is to be on the 'basis of dependent comnensurate property without consideration of prior use, how soon is their is suance advisable?

MR. NIELSON: Term permits shall be issued as soon as possible and practical.

MR. FRANCIS: The need of speoial rules for fair rane practice, and the enforcement of all rules and regulations.

MR. NIE SON: We charge the State Advisary Conmittee with the rosponsibility of gning into this matter, and with the District Advisory Bnards and a represontative of the Department of Interior, to work out a uniform and sound program $n f$ range rules and practioes.

The names of members of the state advisory comitteo are J. B. White, Jas. I. Nielson, Leo Stott, Lyman Sevey; Wilford Clark, Charlos Redd, Stylian Staes, B. H. Stringhem, in the Sheep Division; and Lawrenne Johnson, Bert Buraston, Eה Murdock, Edw. T. Lamb, R. A. Meoks, I. L. Taylar, Jess Conovor and H. E. Seeley in the Cattle Division.

We might say that we endorsed very heartily the work of the CCC camps. In my cm particular district, where I graze, wo have a camp thero, doing wonderful work. The Fountain Green Wool Growers that own largo springs there and put in some troughs, those have been turned over to tho Interior department and thoy have done a wonderful job in piping the vator down to lower levels where we could get at it and placing tanks and troughs. They have completod two of these casos, and we rory hoartily endorse the work of the CCC camps.

MR. METZ OF WYOMING: Iiko the gontleman from Novada, I haven tho honor to be a mombor of an advisory board. I have the honor, howovor, to roprosont at this conference the Governor of Wyoming, who, I may say, is vitally interested in the outcome of your deliborations, as tho Chiof Exocutive of ono of tho greatest stockraising states. I take tho liberty to carry to the Secrotary, to you, Mr. Carpentor, and to you, friends ongaged in the stock business, the greotings of tho Governor of Wyoming, and I add, porsone,lly, that I suppose it is assumed, in calling upon us last, that due deforenco is being paid to tho fact that Wyoming is concedod to raiso the best cattle and sheop in the Union.

MR. CARPENTER: You might start somothing with that.

VOICE: First joke wo've had.

MR. IETZ: Not having a'dditional holp to oarry tho papers -- (laughtor) -Iny apologios to Utah. Wy report will covor tho following throe phasos: First; feos. Socond, the quostions presontod by $\mathrm{Mr}$. Carpentor in the program undor " various hoads. Third, somo rathor snaky-and-woolly rosolutions on our owm', which 
$B-12$

wo bolicvo will bo of gonoral intcrost to this conferonco.

As to tho first, Wyoming rocomends that no foos bo ohargod until such timo as pormits ore is suod.

Socond, as to the various quostions prosonted by the Socretary and Mr. Carpontor undor Soction 2 of "Polioios": Subsoction 2. on dividing dopondont commensurato proportios. The Wyoming dologatos havo dotorminod to rofor this quostion to tho Advisory Board of oach district.

Sub-soction 3: "Should cuts vithin a class bo mado"? Wyoming has dotorminod to rofor this quostion to tho advisory board of oach. district.

Sub-soction 4, as to tomporary allocations of rango in tho 1936 liconsos: It has boon dotorminod that this mattor should bo roforrod, to tho Advisory Boord in oaoh distriot.

As to Soction 5 and tho various itans prosontod in Soction 5, which havo beon moro dofinitoly covorod by other speckers, so thet I boliove you aro familiar with thom, it has boon doterminod by tho Wyoming dologation that thoso questions should all bo roforrod to tho advisory board in oach district, which brings mo to. say that I am now glad I am not a mombor of tho Advisory Board.

Soction 6, doaling with the quostion of tho issunnco of proforontial torm pormits without prior uso: Tho Wyoming dologation most dofinitoly rocommends that issuanco of torm pormits undor tho Act shall bo mado on the basis of dependont commonsurato proporty vith prior uso and not othorviso.

Sub-soction 7 , as to tho nood of spocial rulos for fair rango practico: No action was takon.

Soction 3 on Organization. Itams 1, 2 and 3. Wyoming has determinod that it doos not favor organization undor Itoms 1 and 2 . ivo attompt irould bo mado to oithor suggost or doprivo othors from suggosting rogulations which might better rolations vith oxisting livostock associntions.

Soction 4. Improvomonts. Itoms 1,2, 3 and 4, including tho items which aro familiar to you, among thom CCC camps. No action was takon cxcopt that tho work of tho CCC camps, it is concodod, would bo vory definitoly buneficial.

Doparting now from tho quostions prosonted by the program, I go th tho resolutions of gonoral intorest:

First rosolution: Wyoming dologatos requost that tho rulos and rogulations horotoforo proposod by tho Advisory Board of District No. 1, Wyoning, bo approvod at onco.

Socond rosolution: Tho Wyoming delogation roquosts anondmont to tho Act, or other congrossional aotion, pormitting any state, at its olcotion, as exprosscd by its stato logislaturo, to tako ovor tho public domain vithin its borders for administration, loaso and salo. That rosolution vill, of courso, bo of no particular consequonco to those statos which do not doom such action advisablo.

Third. Bo it furthor rosolved that rulos and rogulations governing tho clection of tho District Advisory Boards, bo rritton into the Taylor Act. Bo it furthor rosolvod that the authority and poirors of tho local advisory boards bo writton into tho Tnylor Aat. Bo it furthor rosolvod that tho District Advisory Boards bo grantod authority, undor tho Taylor Act, to fix commonsurability standards and to grant grazing pormits.

Fourth. Bo it furthor resolvod that wo aro opposod to any rostrictivo amondmonts to Soctions 8, 14 or 15 of tho Taylor Act.

I am furthor advisod, sinco the passago of tho forogoing rosolution, that tho powors-that-bo, our local brass hats from Wyoming on tho Advisiory Board, mot in $a^{8}$ star chambor sossion aftor tho rost of us common poople had gono home last night, and dotorminod that, if tho passago of tho forogoing rosolutions, provid- 
ing the rules of District 1 are approved and become really offective, and the range adequately preserved so that real valie may be received, then that thoy were willing to pay any proper administration fee.

In closing, I will say that I am glad you have all conoeded that wyoming raises the best cattle ond sheep.

(ipplouse.)

NR. OLIVER IEE OF NEW NEXICO: In making hy report for New Nexico, I failed to cover one reported question. That is the question of comensurability. It vas the opinion of our delegation that, for the state of New loxico, hichest consideration should be given, in the appraisement of commensurability, to the owmership of permanont water, and that no permits should be granted or comnensurate property oonsidered without it was attached to pormanent wator.

NR. MYER OF YYOR:ING: I would just like to stato, for the bonofit of this audience, that, contrary to what sore of you people have said, that theso resolu.. tions passed by tho lyoming board, wore all passed unanirously.

NR. CAFPENTER: I wish to say, from ny observation of Wyoming, that, not only do they raise some of the best cattle and shoep, and the most of them, but they raiso something else quite a bit once in a while,

(Laughter and applause.)

NR. HHINERY; Colorado: If the states arc thru, perhaps, as ono of tho minority of the Colorado Delegation, wo should now explain our position.

IR. CARPENTER: M. Whinnery, raises the quostion as to whother, at this time we will receive minority reports. The chair will rule that the discussicn will proceed, as we havo to leave the room for othor uses, thon the rattcr will be placed beforo the house at $1: 45$.

MR. NRIGHT OF NEVADA: So that thero will be no doubt relative to Ile vacla's position, I wish to sny that our resolution also wes unaninous and, furtrer, the resolution in itsolf indioates that wo most cortainly endorse the recomnendations relativo to amending the Act concerning providing definitely for local autonory.

MR. ICFARLINE OF UThF: It saoms that oach stato has had to get up and explain what thoy meant. I foconmond to them to tako their seorotary alone as the Utah man did.

(Laughter.)

NR. CARPINTER: Eefore we proceed to a discussion of those recomondetions, it is only fair to you that a f cw of the a as Socretary Walters terms ther -"Ehosts", that are riundering around, if they can not be allayer, at lecst they can be sorewhat explained.

Thoro wore three mattors taken up in theso resolutions that I feel. I. should corment on bofore wo open this discussion. It was sug. csted that wo urge coneress to do something. You will realize, you district advisors, that, as momors of tine Department of the Interior, noither you nor I can participate in lobbyirg. is individuals - - which you aro at all timos when you have not boon-called in your advisory capacity; and not undor pey by the Department of the Interior -- you aro froo, of courso, to lobby.

I wish at this timo to mako it plain that petitions to Conpress or individual congrossmen, or rosolutions having to do with lcfislation, should not be simed as a district advisor, nor should it be signed "District ldvisory Board". That would be similar to my asking Concress c.s Director of Grezing. You will kindly bear that distinction in view and it will save you and $I$ and evoryono olse cmbarnssmont.

Tho second matter I wish to comment on -- and which in no way curtails your ripht, thru associations and as individuals, to do es you ploase and exerciso 
your rights, but, as mombers of the Dopartment, wo will refrain from lobbying.

As to spooial rulos of the rango. I had, from ovory district, a moss of spocial rulos of tho rongo handod to me with the reoommendation that they be/hendod to tho Sucrotary for his approval, that they bo postod and become a part of tho" fodcral statutos doaling vith that district. Of thoso special rulos, fully fifty. percont of thom wero along this lino: "Wo roconmond that commonsurato proporty consist of pasture land" or "not of pasture land", and so on and.so on. In other words, thoy wore suggestod oonstructions of the Taylor Act. Thoy woro in no sonso spocial rulos of fair rango practico. Thoy woro tho bost rocction which tho board mombors had to tho problom in front of thoin.

You aro awaro that, for mo to submit to tho Secrotary of tho Intorior a construction of tho Act that tho beard thought was favorablo would not bo such a rulo of fair rango practico that could bo applied. For that roason, tho job I had was to tako out construotions of tho lav and put in what would bo rulos of tho range. Thoy incritably consisted of thoso mattors: "Wo rocommond such and such a class of bulls". "So many pounds of salt per crittor hoad". "Wo rocommond" various and othor mattors.

Ono board rocommondod that no hord of shoop bo nllowod to bod twioo in tho samo placo. Ono board in Now Moxico rcoomunudod -. and also ono in anothor stato - - that thoro bo no butchering on the public domain unloss thore had boen a license horotoforo issuod.

I took thoso 34 sots of spocial rules te the Solicitor's office. Ifo went ovor thom very carofully and ho said, "What about this butchoring on tho rango?" I said, "It is a vory dangorous prnctioo", and big Isssos a ro boing sufforod." Thon he said, "Do you think it is c. good, rulc?" I said, "I oortairly do. "If a man wants to butchor, lot him put his hido in the corral, "or ol so got a liconso to butcher on tho rango." Ho said, "Why havon't othor boards passod on it?" I said, "I supposo bocauso it was not prosontod to thom, and thoy didn't think. about it."

Ho said, "What about this mattor of bodding? Is that a good thing?" I said "I think it is.". Ho said, "Why didn't other boards put it in?" I said, "Largoly bocauso thoy didn't think of it."

Ho said, "Isn't this tho truth, that in most oases, tho boards adoptod tho spooial rulos that othor boards had passod, and maybo didn't givo them a lot of considoration?" I had to say, "I think that is s..". Ho said, "Tako thoso spocial rules back, and, whon a board passos thom, havo thom oonsidor all of the spocial rulos that might bo applicablo, booauso, whon you writo statutos in tho Unitod Statos laws, you havo got to do it with consideration of all possibilitios."

That, sounded liko protty good common sonso to mo, and, at tho risk of having to oxplain why I did not submit a ono of thoso rules to tho Socrotany, I thought it would moct with your approval, that you would rathor now havo foims of oach ono of tho 34 sont for your considoretion in ordor thet, whon you do pass this logislation, you do it in a comploto mannor, instoad of passing parti for orio district and part for anothor ono, and then nuxt yoar start ta chango, and back and fill; passing laws and changing thom, and filling thom in in about six months, would givo anybody tho jittors.

I would rathor wait and havo thom right. I bolicvo now wo aro in a position to submit thom to tho local boards. That is tho roason that tho spocial rulos havo not roachod tho socretary.

Tho third mattor which undoubtodly is on ovoryono's mind horo, and an intor esting mattor is whothor, whon wo como to torm pormits, tho prior uso of tho range is going to bo considorod. Sonrch Sootion 3 of tho Taylor Aot; thero is no montion of prior uso that I can find in Sootion 3 of tho Trylor Act. You can find, horrovor, somo words that, until rooontly, moant almost nothing to mo. I bolicvo, now, nltho tho mattor has not boon officially submittcd or approvod, that it is vorthy of your eonsidoration to tako up what was moant by the last words of Soction 3 of tho Aet. 
Whon it said "so far a.s consistent with tho purposos and provisions of this Act, grazing privilogos rocognizod and aclmowlodged shall bo adoquatoly safeguardod", what doos that moan? Now, you toll mo what a liccnso is. I suggcst that a liccnso is a grazing privilogo, rocognizod and ackovlodgod by tho.local board. Is that right? Is it anything clso? Isn't it an oxact dofinition of what vas put in the last part of Soction 3 of tho Taylor Act? Isn't it procisoly a grazing privilogo which, undor the rulos govorning is suanco of liocnsos, has bocn rccognizod and acknowlodgod?

If that is corroct, tho holdors of liconscs that conc up for tcrm pormits will have, in addition to tho commonsurato proportics, which aro rocognizcd in tho first part of suction 3, thoy will havo in addition to that a grazing privilogo that has boon rooognizod and aclnowlodged by tho issuanco of a liccnso.

If that is corrcct and thoro is inadoquato rango $\ldots$ puolic rango $-m$ for all of tho dopondont commonsurato properties of all of tho applicants, it will bo nocossary to nsk for additional quelifications bosidos tho possossion and control of dopondent comionsurato proporty, vill it not? Is thero not a fair chanco that in looking around for the additional collntoral, so to spoak, that an applicant for a term pormit must havo when ho stands in an cqual class with all of tho othor dopendont oommonsurato proporty ownors, and comos to a board that only has adequato public rango for hali of thom, that ho ask tint the lattor part of Scction 3 of the Taylor Act bo considored and thet his rights herotoforo issuod bo considorod a grazing privilogo, recognizod and ackncvledged, and, as the omer of such, that that privilugo bo adoquatoly safoguardod.

I do not know, gentlcmon, whother this will be tho outconc of tho mattor, but I suggost for your considoration that thought, bocauso, if I rightly road tho scnso of this mooting, and if I can rightly prodict the rosult of this assombly, wo aro going to bo horo in anothor yoar, standing on what wo havo dono this ycar, and preparod to tako tho third stop, which is going to bo tho issuanco of torm pormits.

Now, I put thoso throo nattors, with such explanation as I can, bofore you, to wit: tho mattor of lobbying, the mattcr of spocial rulos of tho rengo, and tho suggestion for tho futuro as to torra permits, bocauso, if you approsch tcm permits belioving that they aro going to upset all of the recognizcd grazing privilogos, if you will, all tho work of the boards, all of tho liconscs herctoforo issuod, then indeod you must approach it with considorablo tropidation, but, on tho othor hand, if you beliovo that thoso words put ill thoro almost oxactly dofino what wo aro alroady doing, thon you con soo that thoso with grazing privilogos nocd havo loss tropidation thon thoso without thom, and that the intonso dosiro of tho wost to protoct their prioritios will bo adoquatoly considorod whon wo roach that point.

Now, gentlomon, I como to tho mattor of tho considoration of tho ton rosolutions which wo havo horo, and I wish to summarizo and oall your attontion to this fact, that stato aftor statc in coming to controversial subjects said that thoy rocommended it bo loft to tho local board. You might summarizo tho ontire states' sttitudo by saying that, whonovor you havo got.a, "hot" quostion, "loavo it up to tho local board."

Now, I want to givo you a little history. Thoro aro ropresentativos of tho local boards in front of no. Last summer, in five doys, I met with fivo boards. I met at Burns, Oro., on ono day. I went to Boiso, Idaho, the noxt day; Elko, Nevada, tho noxt day, and Salt Lako tho fourth day, and Craig, Colcrado, tho 5th day. Fivo statos; fivo boards. And I think I got a fair cross soction. I think they woro considoring appoals and, in somo casos, original liconscs. I wish to state, now, that I took tho roquost of thoso boards to heart, and I bolicvo thoy fairly roprosont what tho othor boards want.

This is what I found: Thoy said: "Wo aro only ablo to do half a job, bccauso wo only havo half of tho information in front of us. We do not havo tho statistical information as to tho corroctnoss of thoso statcmonts on commensurato proporty. Hero is a man saying ho has 250 tons of hay ovory yoar. A bonrd mombor tho livos next door to him has boon passing his ranch overy day for thirty 
yoars and novor san but two "doodlos" of hay thoro. Wo aro not going to go into a spirc.l horo and say tho locnl boards aro going to docido ovorything in a boautiful ray and mako us all happy. Thoy on only work vith such tools as wo givo. thom. Thoro is not a mambor of tho local board who thinks ho had good tools last yoar. An I right?

\section{AUDIENCE: Yos.}

MR. CARPENTER: Wo aro going to considor somo bottor tools or olso wo aro going to stand still. I rant to say for mysolf, porsonally, that, unloss this procossion novos along a littlo all tho timo. I an going to loso as much intorost in it as you vill loso in it. I took up a homestoad in 1907 and bought a now grub-hook to cloar tho sagobrush, and most of tho paint is still on tho grubhook, and most of tho sagobrush is still thoro. I want to stay with this outfit as long as you frant to movo.

You can talk about local autonony and tho wisdom of locnl boards and it moans just that (snap of fingors) if you aro going to stand still for thirty days. You havo to colloct and gathor. By coming horo, you aro askod to 'submit tho visdom you havo loarnod from oxporionco -- not as to how good you wero or how stand-pat you could bo, but whothor you could tako a stop forward in doing somothing for tho livostock industry of tho wost.

Whon you say you aro going to loavo ovorything with tho looal board, and furnish them vith no moro tools than Ciroular 2 furnishod them, it moans that you aro going to loavo thom stonding around liko a cow vith a cud. You may tell tho world ro did a "hot" job distributine rango. Do you think wo did such a "hot" job? (Chorus of nogativos.) I don't. I think you aro going to havo to work this yocr hardor than you ovor rorlsod; and, if this assombly disbands and novox puts another tooth into tho thing. you aro not going to be ablo to do anythini moro with tho applications than iso did last yoar!

How long do you think ovorybody is going to bo satisficd rith a rohash of what you did last yoar? Will you bo very proud if jou just do that again? Will this much-vauntod idoa of local solf-govornment wnount to anything oxcopt a woak retroat from thoso tho don't want anything dono? Ari I right? (Chorus of affirmatives and applauso.)

Now, gentlomon, wo aro going to tako up thoso mattors ono by ono, Wo havo asked for froo and full and frank discussion. Wo aro going into an oxocutivo sossion in which tho olootod dologntos of tho 34 boords aro going to talk and oxpross thonsolvos, and thoy aro going to voto by 34 district boards vithout rogard to stato linos, bocauso that is tho only fair way for this oighty nilition acros to bo roprosontod. Is it not? (Chorus of affirmativos and applauso.)

And wo nro going to continuo our policy if you aro villing to back me up in this. Wo want ovorybody to bo horo and hoar it, and if thoro aro any of tho district advisors that don't vont to got up and say what thoy say in tho proscnco of ovorybody, thoy had bottor stay away too. So, in tho twonty-fivo minutos that aro loft us, wo vili not bc nblo to covor thoso quostions. But I an going to tako up ono of thon, and $I$ an going to ask for a briof tino that wo hoar only from tho district advisory boards bocauso I tako it to bo tho sonsc of tho ontiro assombly that ovorything bo loft to tho district boards. Vory voll, it is !!

Now, I an asking tho district boards what thoy aro going to do with it. Thoy put it in your lap. Aro you going to tako it horo with no moro rulos than you had whon you cano horo?. It is a tough job for noighbor to pass on noighbor oven in a rocomondatory way. You may say, "Why got to making divisions and clossifications?" and I will toll you why. Aftor all, this is a oountry rulcd by low and not mon. You distriot advisor's do not wish to docido on tho ppplications of all your noighbors with no rulos to back you, do you? You don't vrant to do it according to your porsonal dosiros. If you don't want to do it porsonally according to your porsonal dosiros, you hato got to havo somo rulos. 
Wo did not know muoh about rulos whon Circular 2 mas mado. Wo know noro about it now bocauso wo havo rorkod - and you gentlemon havo workud joro in dotail vith tho applications than I havo. I could not spond all tho rost of tho winter going from state to stato, and bosidos I rocognizo that if we had a feir number of dologatos horo thoy would rocognizo that this problon has cortain national aspoots.

In Arizona thoy havo an ontiroly difforont sot-up thin liontann and Idaho. It has boon of intorost to tho dolegntos to hoar tho othor soctions of tho country givo thoir points of viow and soo that such regulations as aro issuod must toko a national standpoint and at tho smo timo nust loavo sufficiont josray so that in thoir application thoy rill not como too hard on a distriot whero thoso facts do not apply.

In making our rulos or prooooding furthor with thon wo oxpoct to of for to ovory district board such an assortiont of sharpurcd tools so that the bonrd can look at thoso tools and look at thoir applications, and you vill not havo to say to tho nombors of tho Grazing Division whon thoy cono around, "You did not furnish us with anything dofinito. I don't nind passing on Bill Jonos application if, whon I got out of this room and muat hiz on tho stricot, I can say, 'Now Bill, you got what ovorybody olso in your clnss got, and you got what tho rogulntions, which wo havo dooidod upon, said you should got."

You aro not afraid to do that. That is your job in assisting in this administration. But if you don't havo noro tools to work with than you did last yoar, you aro in tho position of saying to Bill Jonos, "I did tho bost I could for you but tho othor boys woro against mo." Ho prorptly goos around to tho othor boys, and thoy say, "Not at all. Ho was tho first oro for kicking you off."

Nor, I don't fool that way about it, but I do fool that wo haro got to como down to a vory sorious oonsidoration if wo aro going to got down to this assombly somothing to holp tho looal boards in 1936, and it is going to have to bo somo way along tho linos that havo boon outlinod hero. For tho district bourds to ond this mooting with a rosolution that ovorythint bo loft to tho district koards vould put you out of businoss and put loo,al autonomy out of businoss, and put an ond to what I think is a ronl oxporiment in solf-govorumont.

Thore sro too many pooplo in tho United Statos who boliovod that this would novor work, who said, "Whon noighbor passos on noighbor, you will got injustico; whon pcoplo with sclfish intcrosts poiss on others, you got nowhoro." At tho ond of oightcon months, thoy will say, "Tako it and lot an impartinl ran docido on it." Who is tho "inpartial man?" Who is tho Mosos who vill go to Mt. Sinai and dooide thoso things? I don't jnow any sinal to go to, and I haven't got whis zors onough to protend to bo Moses.

Thero is only ono placo I know of to go, and that is tho dosort and you mon who are out hero handling it. Lot's take this baby homo, sot it on our kneo and soo what ro can do with it. I want to say this, as regards the foars in ovorybody's hoart, that I have livod to sco soino of those foars down, and probably I will livo to soo somo of thoso foars pruporly substantiatod. As yet, I havo not socn ono of tho initial fonrs como truc.

At the start of this, I wns just dow in Phoonix, whero they hovo no Taylor grazing districts in tho stato oxcopt tho strip. I an not dociding whothor tho strip is in Utah or Orogon or Mrizonn. Outsido of tho strip, thoy havo no grazing districts in Arizona, and man aftor man, logitimato oporators, livostock oporators, camo to mo and said they don't want a district bocause, when you talk about a local board golng to toll no how to run my businoss, you aro mot talking to mo.

Do you hoar that whoro tho mon know what theso lcoal boards arc? You do not. At tho start of this, whon I wont from stato to state, thorc was not a carcful, substantial, livostocls-man -- and particularly tho lnrgor oporators -that did not havo that foar in his hoart. I ask you mon roprosonting the large and mall oporators if the action of tho local boc.rds and tho stato comittoos in thu confuronco last night did not cxpross sufficiont trust in locnl bocrds to 
allny that foor onco and for all. Do you boliovo that?

(Chorus of affimativos and applauso.)

Vory voll. Thon thoso substantial operators in Arizona havo a foar that is unfoundod, that wo havo allayod. Nor, thero anothor foar that, whon wo startod off, soonod to possoss ovorybody, and that was that cattlo and shoop mon could not got along. I havo attondod board nootings, not lenowing whothor tho non woro cattlo or shoep non, and, hoaring thom pass on applications, it was impossiblo to say whothor thoy woro oattlo or shoop mon. Isat that right, gontlomon of tho boards?

\section{(Chorus of affirmativos.)}

So you havo got a rooord of roal accomplishmont. You bury this old idoa that, if you aro a shoopran, you want to wrook tho rango, and, if you are a cowman, you want to wrook tho shooprian. That is bohind us.

Thon wo aro not afraid of a domocratio sot-up -- ono man; ono voto -- and wo aro not afraid of tho boards passing on thoso applications. Wo havo got thoso follows in back of us.

Now, wo havo anothor foar that is in front of us, and that is the fonr that was oxprossod, that it would not all bo loft to the looal board. It is all going to bo loft to tho local board in a rocomondatory wry, but tho local board will bo unablo to function in a way oomondablo to itsolf or in a voy in which it can advanco in tho adrinistration unloss it is furmishod vith moro tools than Ciroular 2 gavo it.

So that brings us down to tho quostion of whothor wo aro roally going to do somothing with thoso mattors or not. I havo divided it into four subjocts: allotmont of rango, division of dopondont proporty, dofinition of dopondont proporty; and foos.

In coning now to tho first subjoct of allotnont of ranges, I ari going to mako a briof oxplanation, thon $I$ an going to call on tho difforont board norbors for an oxprossion of opinion. Wo havo fiftoon minutos to discuss that, thon wo will tako up tho othor subjeots. If wo do not finish tho othor subjocts until six o'olook tonight, wo vill thon havo arl ovoning sossion to tako up tho matter of organization and improvononts, which is not a nattor for dobato, but a mattor just to bo prosontod by solcotod sponkors. But, if this assembly anounts to anythins, wo aro going to do sonothing, and $I$ talso it to bo your will to stay right hore until you do it. Is that right? (Applauso.)

Tho allooation of tho rargo: Somo agroo it should bo dono; all sny it should bo loft to tho looal boards. Difforont onos wonder this way or that wey how to do it. It is impossiblo, in ny opinion, to advanoo in any ray in tho adninistration of tho rango without untortaking, in somo way, an allotmont of it.

\section{(Applauso.)}

Now, I fool that thoso 34 roprosontativos of 34 bocrds, should talio a firm stand on that. It is a littlo hard for a looal board mocting alono, if loft ontiroly disorotionary with thon, and an oporator conos in -- nnybo a friond of yours -m and ho says, "You don't havo to do anything with allotmonts this yoar." Wo aro all human; wo all try not to troad on any moro toos than wo havo to, and wo vill all take tho oasiost way out of it. I have found that so and no doubt you havo. If it is tho unanimous opinion of tho 34 distriots horo that sono allotmont should bo mado, thon, if you mako sono allotmont, you oan say to tho man who objoots: "Tho board had no disorotion; wo had to go into somo nllotmonts.

Would you rathor do that, or would you rathor say to tho man: "It was lort to us, whothor vo would do it or not, and wo dooidod to do it." Isn't it a littlo fair, now that wo aro all horo, to mako ono rulo, a gonoral. rulo, whioh will 
apply to tho 34 districts as to whothor thoy do or not. As to horr much is dono, that will depend on the local boards, but I doubt whether any of thon will over touch that subjoct unloss somothing is dono about it.

In Utah, Colorado, Idaho, Montana, California, . Orogon and Novada, tho natter has bocn moro or loss a noot mattor, and I dcrosay, until it vas brought up and brought to your attontion yostorday, many of you dologatos did not ronlizo it was alnost impossibio to, continuo oporating this show if wo did not. tako ono stop formard, and that ono stop formard ras noccssarily sowothing bottor thail wint wo hevo dono.

Wo havo passod on numbors and listod usors. Wo havo'a rango cxarinetion sufficlont fron a practical standpoint, whon appliod vith tho brins of tho livostock industry, to mako somo allotmonts or the rangc. Thoy may bo in some dism tricts cnly allotionts by classos -m no simplo cattlo and shoop lino -- but whatovor you do is geing to bo backod up and incorporatod, if that is your vish; in ovory liconso issuod.

Tho rattor of onforcciont is going to bo done by tho Dopartincnt. You havo boon told that tho administration of tho ranco can not bo dologatod, and it can not, but tho rogulation of tho rango has boon placod nlnost ontiroly vithin your honds. In $97 \frac{1}{2} \%$ of your rocomondations for liconsos, your docision was finnl, bocauso it was adoptod by tho Socrotary of tho Intcrior. Don't lot anybody toll you that, bocauso you havo no final say in administration, you cinount to nothing. Thoro is loss than $2 \frac{1}{2} \%$ go any furthor. For tho groat mjority, your action is final, bocauso it is approvod by tho socrotary. But, on tho mattor of cnforconont of rulos, wo do not oxpoct you to talio any stop furthor than a postod notification of advico, and wo fool that tho fodoral onforccilon's agencios should tako caro of tho onforconont alono and singlo handed -.. how do you liko it?

\section{(Applauso.)}

Pooplo rosont a distriot board mabor conirg out and trying to polico tho district, and I don't think it is fair to ask you to do it. I aduit thoro was somo quostion in my mind thon wo started. Thero is nono now. The Division of Investigations invostigatod homestoaders when wo had thon, but thoy hevon't got thom any moro. Thoy aro adequatoly proparod to mako thoso invostigations, and spoodily. Wo havo; organizod in tho Unitod Statos, a complete fodornl judicinry that can handle it, and violations of tho Taylor Grazing Act rulcs will simply bo liko violations of postal rulos, violations of narcotic rulus, and othor fodoral rulcs, and should bo takon carc of in tho sanc mannor.

When tho local boards roalizo that thoy don't hawo onforconont nattors in thoir hands at all, that thoy aro moroly rocomordatory in tho adrinistintivo mectings as divorcod fron onforconont, I bolicve it will bo a velcono aircurscribing of thoir dutios and that thoy will bo able to soo moro cloarly what thoy vill havo to do, and that thoy rill moro choorfully undortako their dutics, bocauso thoy vill rot havo tho onus of tho onforconont of tho crininal law upon thon. For that roason - It is now 25 rimutos aftor olovon, and vo sivo up this roon at 11:30 -. I an going to adjourn this nooting until $1: 45$, and ask tho dolcgatos to bo promptly in thoir soats at that tino and wo will takc tho mattor up for discussion. Tho nooting is adjournod.

(Roooss for lunch at 11:30 AM.) 
(Meting called to order by Chaiman F. R. Carpenter at $1: 45$ PM.)

Wo have taken lots of bad nows. You have taken Iots of bad nows during the year and I have takon a Iittle, but thore are two vory fortunate happenings that have started vithin the last year. Ono wo had nothing to do with, and we taiko it as it comes, and tho other you have all had soncthing to do with and now you are going to tako it as it is told to you.

The first is the rain. I lnow that you are all slad to have this rain and that it rill do a lat of good. The second is a telogram rocoived from the sceretary this morning, about a Inng-nooted and dobated quostion. Socrotary Waltors is going to prescnt that to you.

MR. WALTERS: Friends of tho westcrm states: There vas roceivod at $12: 13$ 'clock this afternoon, the following tologram, addressed to mo, in response, to a telegrar which was sent out by me yosterday afternoon. I will read you tho telcgram, which is all that vill be necessary, I apprehond:

"Department has hold that procoeds of assesments loviod on grazing licenses by division boards aro private funds and not public nenoy."

(Applause.)

"Funds already collected may bo oxponded by the boards for purposes for which collected if such purposes aro not unlaviul or in violation of departmontal regulations. The proceduro in levying assessments, in many instancos, howover vas improper and no furthor assessmonts should be risdo until dopartmental rogulations aro issued. Harold I. Ickes, Secretary of thd Intorior."

MR. CARPENTER: Thanl you, Mr. Socrotary, end, thru you, wo thank socretary Ickes. Wo have waitod a Iong timo $\mathrm{fcr}$ this. It means, gent lenen, that your funds are roleasod. It means you can go on spending then for the legitimate purposes for which they woro loviod. It means that thero vill bo fortheoning vory soon rogulations that vill guido ynu botter in the collection of thoso funds in tho future.

Tho improprietios mentionod in the tologram refer to our using frankod onvolcpes -- as much of a roflection on mo as on anyone, bccausc, in some cases, thru mistakes, district boards usod frankod cnvolopes to collect privato muncy. That was impropor. It was not dono intentionally and it is not a Cluss A offenso under the folony acts of tho govermment.

Theso things you will have now, and also instructions rogarding the pressure -- vhich the Govornfient is villing to back you lip in -. in tho donial of liconses and so forth in tho colloction of the balanen. Wo will ask you not to try to collect any of the balanco until instructions are issuod, but thoy are now roleased, and you can go ahead and use thon.

Now wo will procood to businoss. I an roferting now to tho logally accredited dologates of 34 districts, who will take tho sole part in tho discussion beforo us, tho privilogo of tho floor having boon accorded to all concrs up to this timo. Thoro will bo a roll taken of all of the 140 dolegatos horo proscnt.

MR. WHINNERY OF COLORADO: I rish at this tiro to yiold my p.noe until our Colorado comnittoo completes their goneral roport, thon I wish to d'oll sw thoir report. Tho roport that they are gotting now, wo are all agrocd on, and I bolicvo they aro roady to mako that roport. 
MR. CARPENTER: At this timo, the Choir vill rulo that any further repurts from stato com:ittoos aro out of order, that tho time is short onough now that wo will talo up oxocutivo businoss, that all further stato roports can bo filod at tho desk and bo complotod in tho rocord or, aftor tho complotion of our loxocutivo business, will bo takon up in full.

MR: WHINIJERY: How about the minority report.

MR. CARPENTER: " That will havo to bo filod now. As wo havo passod thoso reports, I take it that you will not wish to go further into that at this timo. If it comos up in tho topics, you, being a regularly accroditod dologato, you con spoak on that topio and spoak your mind.

MR. WHINNERY: Thanle you.

MR. CARPENTER: Tho first topio is tho mattor of allotmont of tho rangc. Tho quostion is whethor wo should undortako, in tho 1936 liconsos, to to.clic tho problon of allationt of rango. Tho Chair, in ordor to bring it to 0 head, vill cntertain a motion in regard to what should bo done on allotiont of the rango.

MR. TAYLOR OF NEW MEXICC: I offor this resolution: Rosolved that somo rango allotmont bo mado in all 1936 liconsos providini nocossary information is availablo for such action.

MR. CARPEITER: If you will hand that to me, I will read it thru tho "rilko".

(Mr. Taylor hands tho rosolution to Mr. Carpenter.)

MR. CARPENTER: "Rosolvod that somo ranco a.llotmont bo mado in all 1936 liconscs, providod necossary information is avnilablc for such action." Is that correct, Mr. Taylor?

\section{MR. TAYLOR: YOS.}

MR. CARPENTER: Do I hoar a socond to that motion?

VOICE: I socond tho notion.

MR. CARPEITER: Motion is mado and sooonded. Wo will now oall for discussion of this motion from tho oloctod dologatos.

MR. TOBIN OF NEVADA: I wish to add tho mondment: that all allotments grantod during 1936 be subject to tho discretion of tho district board.

MR. CARPENTER: Tho anondmont offorcd was a proviso that all allotinents would be subject to tho action of tho district boards. I may say, in ordor to clarify this, that this docs not compol the boards to nolrc any particular allotmont, but it doos say, and it leaves them tho judgo, as to whether tho necessary information is availablc, but, if tho nocossary information is availablo, it vould roquiro oach board to tako up tho mattor of allotmont and act on it. Thoy might make only one allotmont or tes, but thoy rould havo to act on that natter, providing thoy first had sufficiont informetion availablo to do so prudontly. Doos that answor your ariondinont?

MR. TOBIN: Tho words I usc aro "the discrotion of tho advisory board."

MR. CARPENTER: Ho adds that his amendmont is that ho rould mako tho grantins of allotmonts discrotionary vith tho district boards, instend of roquiring' tho district boards, if thoy find thoy havo the availablo information, to 50 , into the nattor. Aro you roady to discuss tho arondmont? Tho Chair rocognizos kir. Cox of Utah.

MR. TOBIN: I ariso to a point of ordor. As makor of tho mondront, I boliove it is my right to first spoak on tho anondmont. 
MR. CARPENTER: That is correct. If you vish to do so, you ray havo that right, right now. Will you como up in front of tho "riko" ploase?

It has bcon callod to tho Chair's attantion that sono of tho dologates soats are ocoupiod by thoso who aro not dologatos. Will you ploaso do thom tho courtosy of vacating tho soats so the dologatos can got thoir soats? Wo will tako a short roooss until tho delogates oan occupy thoir propor soats.

Gontlomon, Sonator Tobin of Novada will prosont an anondnont to this motion. I ail going to asl hin to rend the notion and the arnendrient, and thon spook or $i$ t.

MR. TOBIN: I will road tho notion, as stated by Mr. Carpontor, that somo range allotment bo mado in all 1936 liconsos, providod nocossary information is available for such action. Tho amonduont I nado from tho floor a for minutos ago is as follows: that allotmonts bo grantod subjoct to tho discrotion of tho advisory board in which application is mado.

My roason shall bo brief. I fool that tho advisory boards aro bost qualifiod to pass upon thoso allotmonts. I do not boliovo it is propor for us at this tino to mako a blankot rulo covoring all applications for allotnonts in tho various statos which aro roprosontod horo today. I think, as I havo said alroady, that the mon you hnvo elooted to roprosont you as advisory boards havo suocossfully fulfillod tho job you gavo them. Lot's lot thcil carry it on and soo whothor you are ontitlod to an allotwont.

MR. CARPENTER: In ordior to sRve timo and got thoso issuos cloar, I an wondoring if thoro is an issuo botwoon tho original notion and tho amondnont. I an going to ask tho sonator a quostion and got his answer, and sce if wo can got this thing oloarly beforo us:

Do you undorstand tho original motion to bo such that tho Board is deprivod of thoir discrotionary potror in granting or vithholding individual allotmonts?

MR. TOBIN: In naking my anondnont, Eontlonon, it was vith tho intontion of clarifying tho original motion. I for ono would be willing to withdraw ny anondmont, and tho othor man who mado tho othor motion vithdraw his, and incorporato in ono, if it is agrecablo to you a.ll.

MR. CARPENTER: Would you like to rait and rodraft tho erondiont, putting it all into this form, or do you wish to wait and submit it as an mondmont to tho original instoad? nont.

MR. TOBIIV: It would bo satisfactory to no to withdraw both motion and anond-

MR. CARPENTER: Can you rodraft tho motion right now?

MR. TOBIN: YOS

MR. CARPENTER: At this timo, wo will procood with tho dobnto on tho anondmont, and tho Sonator will rodraft it. Will tho consont of tho man from Now Moxioo bo Erantod to such a proceduro? kring out.

MR. TAYLOR OF NEW MEXICO: I don't know until I know what ho proposos to

MIR. CARPENTER: I vill ask Sonato. Tobin and Mr. Taylor to sit dow together ani rodraft that anondmont. In ordor to savo timo, whilo that is soing on, wo vill procood to anothor topic.. Maybo wo vill want scho rosolutions drnftod on another topic. The noxt topic is tho natter of the division of dopondont proporties - division into classes, whoroby those vithin or on tho fringo of tho district are in ono class, and thoso not within tho fringo of a district are in a junior class. 
MR. CHRISTENSEN OF CALIFORNIA: Last night, in our discussions with referonco to dopondont proportios within or noar, or contiguous to a district, wo thought, for tho bost intorosts of thoso who uso tho public domain, that tho word "conti guous" may bo a littlo misconstruing and wo vould rathor havo thoso within or ncar a district. Wo havo thought about it a good doal sinco, and our bormittoo offors tho prosont resolution:

Rosolvod: That dopondont proportios bo soparated into thoso vithin or near a district and thosio not so noar a district.

\section{MR. CARPIENTER: Do I hear a second?}

VOICE: Road that again ploaso.

MR. CHRISTENSEN: Rosolvod, that dopondont proportios bo soparatod into thoso within or noar a listrict, and thoso not so noar a district.

\section{MR. DORRIS OF CALIFORNI : Socond the motion.}

MR. BRAY OF COLORADO: That might bo all right, but wo would have to havo in that a oustomary usago. If property in ono district has boon usod as conrensurate, in another district it cortainly will havo to bo ncor -- not noarost, but noar anyray. Wo can't subnit to driving out of Utah 200,000 hond of shecp in tho wintor. In colorado, wo havo non who havo wondorful ranchos and cormonsurato proporty; that proporty should havo to bo usod just tho sario as if j.t ras in Utah. I an doubtful that Utah has onough comensurato proporty to take care of that livostock.

MR. : CARPENTER: Boforo wo go further with tho morits of this quostion, I wish to raiso tho ono of fom. Do you think this is in the right fom to bo considorod, or would you liko a comittoo to rodrnft this littlo infomal rosolution to bring it straight bcforo us?

VOICE: It should bo rodraftod.

MR. CARPEITTER: Tho Chair will ask Mr. Christonson of Califormia and Mr. Moforlano of Jtah to rodraft that rosolution to fairly prosont it to tho assombly.

MR. CECIL OF OREGON: On behalf of tho Orogon delogation, I wish to mako tho following notion: Rosolvod, that further and moro definito dofinitions of commonsurato property be mado.

MR. CARPENTER: Lot's soc if I can quoto that corroctly. Mr. Cocil, on this topic of further and moro dofinito dofinitions of colunonsurate property, has movod that further and moro dofinito definitions of comonsurato proporty bo made. Is that corroct, $\mathrm{Mr}$. Cocil?

\section{MR. CECIL: Yos.}

\section{GENTLEMAN FROM CALIFORNIA: I socond tho notion.}

- MR. CARPENTER: Is thoro any point about the form of this notion, or is it clcar onough to proporly bring it up? It would socn that this is vory cloarly put. That does not raiso tho question as to how you vill dofino it, but just simply that it is dosirod that furthor and moro dofinito dofinitions of comonsum rato proporty bo mado. Ponding tho bringing in of the othor tro rosolutions, to bring tho matter beforo the delogates, wo will take up tho quostion, which is nor boforo tho houso, that furthor and more definite definitions of coninonsurate proporty should bo mado. Wo trill hoar romarks on that quostion.

MR. LEE OF IDAHO: That is an anstrer tio quostion No. 5 ?

MR. CARPENTER: Is it, Mr. Cocil? 
MR. CECIL: YOS.

MR. CiRPENTER: Yos. Doos anyono vish to mako any romarks for or against tho further dofining and making moro dofinito of what is comensurato property?

MR. FRINCIS OF UTAH; On tho mattor of furthor defining, it has boon brought boforo our attention in our Board, and porhaps in yours, tho mattor of whethor forost pomits sholil bo considorod as comonsurato proporty. I don't soo it listed horo and I think porhaps wo should havo a discussion on it.

MR. CIRPENTER: Tho mettor of rhothor forest pomits, or baso usod for forost pomits, should bo considorod as commonsurato proporty -- should this rosolution not pass, it would not bo nooossary to considor that. In an assomblago of this kind, Mr. Francis, and with the linited tine wo have, 1t rould socm to me that the mattor of forost pormits as comonsurato proporty, and basis used for forost permits as cormonsurato proporty, the only reasonablo way we can got at it is to havo a drafting comittoo and oonsider closo study by a snall body of mon. Our idoa is that, winon tho Division of Grazing has droftod, as noar as thoy can, along tho outlinos as put on this progran, that it would thon bo sublittod to tho advisory boards for oritioism. I fcol, in a mooting of this kind, to opon up on forost pomits would not, ot us anymoro. Wo aro mory donling with tho brond principlo. Do you want us to work out a fair basis for forcst pormits along with othor things? Would that bo tho rishos of this asscrably, and not 60 into detail? I fool it would fot us into a long discussion and roally ro could not "button it up" whon wo woro thru.

MR. WHINNERY: In viow of what you havo just said, I boliovo that our chairman hore, Mr. Pitchforth, should so out with the comittoo you just sent out -Mr. MoFarlano and Mr. Christonson -- as wo aro doubly interosted in that vory quostion, and it would probably savo tino by hin being out thoro and satisfy this Eroup of nion or anyono that ho may designato.

MR. CARPENTER: Mr. Whinnory of Colorado askod for tho courtosy which can only bo oxtended vith tho unanimous approval of tho houso. Is thoro any opposition to Mr. Pitchforth boing added to the o maittco? (No objoctions). If not, it is so ordorod, and wo vill ask $M r$. Pitchforth to rotiro with that comittoo.

VOICE: Would it bo right at this tino that wo bogin to dofino conmonsurato proporty -- to go into tho goographical rolationship of it?

MR. CARPENTER: That would oomo undor tho distancos of dopondont property and not undor this.

Aro thoro any furthor romarks on this resolution?

IRR. TOBIN: I an spoaking on my original anondnont. If I an in ordor at tho prosont tirio, I vithdraw tho ariandront. I undorstand that wo havd a substituto motion.

MR. CARPENTER: Would it bo with your consont, Sonator, that wo finish the one wo aro now considoring and thon corio right back to yours? Aro thoro any further remarks on tho nocossity for further dofining and malring moro definito what cormonsurato proporty is?

MR. IEE OF NEW MEXICO: Isn't that a rathor complicated quostion for this body to determino at this tino? Colmonsurato property in one stato may not, havo the samo valuo as it has in somo othor stato. We in Now Moxico, of courso, ounsidor that rator has tho highost comonsurability, and that tho othor oomonsurability must bo joinod or connootod with that ormorship. So whet itits Colorado, Moniana and Utah might not fit New Moxioo or Arizona. I hopo you vill bear that in mind. 
MR. CARPENTER: That is corroct. In Colorndo, in gonoral, whoro I lived in tho mountains, rator would havo no valuo at $a l l$, and, in Now Moxico, cultivatod food vould havo no value. Tho idon wes that this vould bo an oxprossion from tho assoiblod dologatos of tho district advisory boards, that thoy dosiro, boforo, thoy start thoir doliborations ovor liconsos, that thoy vould liko a littio bottur dofinition of pomnanont mtor in Now hoxico, and a littlo bottor dofinition of food and othor classos of proporty -. malio thorn a littlo moro sharply dofinod and lanoul tho valuo of each of thon. Wo aro not going to go into what thoy aro or hov to do it, but, if it is tho dosiro of tho district advisory boards, as I undorstood from my mooting rith thon, that thoy vantod thoso things mado moro dofinito and pooplo wantod to buy this proporty if thoy roally know what to buy. It is only fair to thon, bocauso thoy might bo put out of businoss if thoy don't-got it, or thoy might got tho rrong kind of proporty.

It vould in no woy put a difforont kind of proporty into a difforont stato. From thoso toin statos, and from thoso dofinitions, tho district bocrds vould pick out tho onos that apply in thoir districts and only thoso. For instanco, tho nor circular, if this rosolution passos, vill havo a moro dofinito dofinition of tomporary or permnont vater. It vill, also havo a bottor dofinition of food put up and food purchasod, food wich is actually fod and food which is raised and not fod. Cash crops roro throrm into tho hoppor last yoar. That vas obviously unfair, but it vas duo to tho fact that our dofinitions roro not vory prociso.., "N

If this rosolution oarrios, you vill havo a moro dofinito sot of dofinitions of tho various kinds of comonsurato proporty. Tho Boards rill thoroforo tako out that circular and uso tho onos applicablo to thoir districts in passing on applications. Iny furthor romarls on tho nocossity for furtihor dofinitions of comonsurato proporty? fro you rondy for tho question?

VOICE: Do wo undorstand you now, in viow of whet floor comont thoro is horo, that, boforo wo bourd mombors attompt to dofine in individual casos, wo vill got a rogulation from your offico?

MR. CARPEITER: Tho quostion ms whothor tho districts rould undorstand, if this passod, that thoy rould not poss on 1936 liconsos until thoy had moro dofinito dofinitions. And that is oxactly right. $\Lambda$ passing of this rosolution will moan you aro dissatisfiod to go anothor yoar vith Circular 2 as it vas issuod and you vant sonething to go a stop furthor to uso in your doliborations.

MR. DORRIS OF CiLIFORNIA: Ovor in our stato, wo no a littlo bit difforontly situatod than any othor part of tho Unitod statos. Wo aro in a high altitudo and our dopondont $\mathrm{r}$ oporty is what wo aro producing, which wo can only narlict vith what livostock ro havo. For that roason, it is dopondont comronsurato proporty wo shall stand on in our country. It is not dopondont rpon tho rango just to raiso our stock in tho surmor so wo can got thon off our ranohos long onough to harvost our crops and bring thon in and markot thoso crops which wo raiso thru our livostook, so our comonsurato proporty is very much difforont from what it is in Arizona.

It is dopondont upon that rango or wo oan't mko a go of it and that is tho only tray wo can markot tho produco which ro reiso in our country. This is for northorn California.

MR. CARPENTER: ANy moro romarks boforo tho quostion is subrittod? I vill first call for a voico voto, thon, if thoro is any dosiro for a roll, onch district advisor duly accroditod vill bo pollod and his voto rocorded.

Thoso in favor of tho rasolution that furthor and noro dofinito dofinitions of commonsurato proporty should bo mado, vill signify by saying "ayo"......... Thoso opposod, tho saro sign....... Tho "ayos" havo it unanimously.

I will ask $\mathrm{Mr}$. Tobin to spoak on tho nor rosolution that ho and Mr. Taylor have agrood upon. 

B -27

VOICE: Supposo that is changed to "qualifiod applicants" instond of "qualificd porsons"?

IR. CARPENTER: I thirl that is a 800 peint. Would tho word "tonpnrary" suit you, Mr. Tavlor? I vill do a littlo drarting and soo if wo got this right. Tho rosolution now roods as follows: "That somo tomporary rango a.llotmonts may bo nado in all 1936 liconsos to qualifiod apnlicants, providing noccssnry infomation is availablo for such aotion, and subjoct to discrotion of adrisory boards whon applicotion is subrittod."

MR. OLIVIR LEE OF NEN MEXICO: Would you mird roading tho rosolution agnin, vory slowly, so wo oan Eot tho full sonso?

IR. CARPENTER: "Rosolvod, that somo tompurary rango allotinents may bo modo in 0.111936 liccnsos to qunlifiod applionnts, providins nooossary information is availablo for such action, and subjoct to discrotion of idvisory Boards whon application is subrittod."

$M R$. OLIVER LEE: Pardon no. I think tho word "somo" should be strickon.

IRR. CNRPENTER: If thoro is no objoction, wo will not chango any wording at this timo. Wo vill just disouss tho notion.

IIR. DORRTS OF CiLIFORNIS: " Just one rord, that is "qualifiod npplicants". It might bo that tho advisory bonrd would fool liko a man that mas not qualifiod to cot a pomaniont pormit should bo allowod a pornit for this yoar, or toiporary iiconso. I would not rant to bo tiod to that.

MR. CARPBNTER: This is a "qunlifiod applicant", not a qualifiod proforonoo pomittoo, and overybody is a qualifiod applicant that is a citizon or doolaros his intention to bocone such.

I vill road this again: "That sono temporary range allotinonts may bo mado in all 1936 liconscs to qualifiod appliccnts, providine nocossary information is availablo for such action, and subjoct to discrotion of idvisory Bcarcls whon application is subizittod."

IRR. OLIVER LEE OF NEW MEXICO: I Movo that tho rosolution bo anondod by substituting tho rord "shall" for "somo".

IR. CIRPRNTER: Tho arendrient is offurod that, instond of roading that "somo tomporary rango a.liotmonts my be mado", that "somo tomporary allotmonts shall bo mado". Is that corroct? Do I hoar a socond to the ariondrient?

\section{VOICE: Socond.}

IR. CARPENTER: Aro you rondy to dobato on tho anondront change, which is to chanco tho vord "may" to "shrli".

IR. RHDD OF UTH: If wo chnngo tho rord "noy" to "shnll", it will destroy or nullify to somo oxtont tho diccrotiwnary powors that wo niso grant tho Bonrd, so, in this particular rospoct, I thinle it should stand as it is.

MiR. CARPENTLR: Wo havo on Jugh to go ovor. I n.l going to ask that all discussion on tho notions bo linitod to two nimutos occh. Would that bo with your wishos?

IRR. TOBIN: Tho chair nood not bo afraid that I will tako up vory much timo. I agreo with tho gontloman from Utah. I considor that the rionducnt proposod would dostroy. tho intont of tho rosolution. I sincoroly hope tho fontionan from Now Hoxico will ronlizo that and kill tho anonduont.

MR. MCFLRLNE: I would liko to soo that word "sumo" out out ontiroly: booauso I think it wookens it. 
IR. ClRPEYTER: Point of ordor. You will confino yoursolf to tho notion.

IR. OLIVER LEE OF NEW IEXICO: I an afraid you got mixod up on ny nacndmont. It was the word "some" that I objoctod to.

MT. CLRPINTER: I will road tho rosoluticn again: "Rosolvod, that somo tormporary rango allotmonts may bo mado in all 1936 liccnsos to qualifiod applioants, providing nocossary infomation is availablo for such action, and subjoct to tho

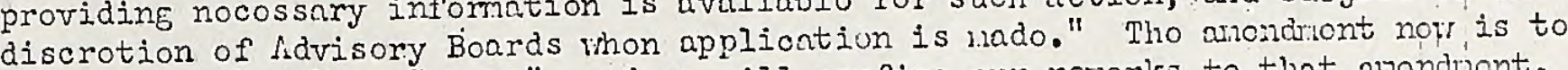
cliango that "may" to "shall", and wo will confino our romarks to that anondriont.

IIR. OLIVER LEE: Pardon mo; I don't objoct to tho word "ray" hut I objoct to tho vord "somo", which is indofinito.

NR. CLRPTITER: You wish tho word "sono" strickon, and you wish to withdraw your fomor siondnont.

MR. OLIVTR LEE: Yos, as it is undorstood.

IR. CARPEITER: With tho consont of tho houso, lír. Loo vill vithdraw his formor ruondront, and sugGost a chango roading as follows: "That tonporary rango allotmonts may bo mado", vith no "somo" in it. Now, what do you say? Quostion is on tho anondnont to tako tho "somo" out. Aro you roady for the quostion? AII thoso in favor of takine tho "somo" out, veto "ayo"....... Thoso opposod, tho sano sicn...... (ono opposod)........ In tho absonco of a request for division, tho "somo" vill bo talion out.

MR. REDD; OF UTIH: I novo to furthor anond by striking tho last four vords of tho motion. If you vill road tho notion with tho last four rords olininatod, I think it will bo simplor and noro cloar.

IR. ClRPENTER: Tho arondod rosolution roads as follors: "That tomporary rango allotmonts may bo mado in all 1936 liconsos to qualificd applicants, providing nocossary information is availablo for such action, and subjoct to tho discrotion of $\Lambda$ dvisory Boards, whon applicntion is mado." Thoso aro tho four disputod trords: "Whon application is mado." Tho motion of IIr. Rodd is to striko tho words, "whon application is mado."

I vill now road tho motion as it would road vith troso four words onittod: "That tomporary rango allotmonts may bo mado in all 1936 liconsos to qualifiod applicants, providing nocossary information is avaliablo for such action, and subjoct to discrotion of Advisory Boards" poriod. Any discussion on that.

IR. TOBIN: I would liko to ask tho Gontloman from Utah, thru tho Chair, his purposo in his ariondront.

MR. CARPENTER: Tho Chair vill ask Mr. Rodd to oxplain tho purposo of his anondmont.

IT. REDD, I thought it vas a short cut and would save asking ifr. Tobin tho quostion of tho nocossity for the vrords in tho first placo.

MR. C:LPENTER: I rish to say to tho sonator from Novada that, whon you talk about rosolutions, you want to lnow your stuff.

$\mathbb{R R}$. TOBIIS: I ask that tho chair bo authorizod to cast tho nocossary voto.

LR. CARPEHTER: Tho Chair has strickon out tho four last words, and vill road tho rosolution, whioh, with your consont, will bo prosontod now for dobato. "That tomporary rango allotmonts may bo mado in all 1936 liconsos to qualifiod applicants, providing nocossary information is availablo for such action, and subjoct to tho discrotion of Advisory Bonrds." Iny furthor romarks? Roady for tho question? $\Lambda$ ll thoso in favor of tho rosolution as anondod, signify by saying "ayo"....... Opposod, sane sien..... (nono opposod)..... Carriod.

Tho Clair will now ask Mr. Christonson to roport. Will you como up to tho "riko", Mr. Christonson, ploaso. 
I:R. CHRISTENSEN: Wo did not chanco our originnl notion. Wo ariondod it vith a littlo addition. I vill roed tho ontiro notion at tho prosont tino: "Rosolvod that dopondont proportios bo scperatod into thoso within or noar a district and thoso not so noar tho district, with first profurcnco to bo fivon to tho oimor of land and livostock shoso ormorslip doponds on tho uso of public lands odjacont to his proporty and who has had sufficiont prior uso."

ILR. CiRPENTER: lNy socond to that notion? I call your attontion to tho fact that this motion goos a stop furthor, and goos to zoning vithin districts.

IR. BRIY OF COLOR:DO: Wo aro not altogothur satisfiod with tho now notion. To got awry fron this "noar, noaror, noarost" businoss, I vould lilo to mako this as a substituto rotion: that noithor district nor statio linos shall bo considorod in dotomining comonsurnto proporty, and that only custorary past uso' bo oonsidorod. (Ispplauso.) ariondnont?

IR. CARPEITER: You havo hoard tho ninondiont. Is thoro a sooond to tho

\section{VOICE: Scoond.}

IR. CLRPENTIR: Wo vill honr remarks on tho arondnont, which is that stato linos will bo disrogardod and nothing oonsidored but customary uso.

NR. BRiY: Tho rosson thet I nado that motion, I had a groat doal of cxporionco in holping draw thoso district linos. Stato linos, cousty linos, and inaginary linos, coning up otomilly. Wo voro assurod that tho district linos rould only bo tomporcry and, with this assuranco, wo consontod to uso stato lincs. Ifow if wo had had our way about it, wo would hevo talion in tho onstorn part of Utah in our district, and would havo bcon blad to, but wo did not havo our way. Now tho stato lino is tho district lino. Tho comonsurato proporty lios in colorado. To cot this comonsurato proporty usod whoro it has boon in tho habit of 'boing usod is tho purposo of my notion. (Applauso.)

IR. REDD: I an opposod to tho motion. I boliovo you gontlonon vill arroo that, if this rotion provails, tho irtont of tho hot itsolf vill bo mulifiod. I romind you of Soction 3 of tho let. It is truc tho passago of this rosolution will allow tho porsistonoo of past practicos, but ronowbor tho ict was passod to corrcet bad practicos, practicos that roro unfuir to tho pooplo who happonod to livo adjecont or on tho rango. Wo havo not hoard uno statcriont fron tho sontloman fror. Colorado in opposition to tho statoncmes mado yostorday about Grant and Sen Juan countios. Our land and irrigation vetor is vory linitod. Wo aro doponding ontiroly upon this vintor rango. It is truc, if Eastorn Utah was includod with Wostorn Colorado, thoy, ovor thoro, at tho foot of tho Rookios, with thoir. plontiful wator and nico ranchos and forost poritits, vould havo an idoal sot-up.

Thoy havo got tho suraior rango and have got tho ranches. But what aro you soing to do vith tho toms of Monticcllo, ctc. Thoy aro out on tho dosort almost liko old oows or broun-tailod horsos around i.lkali springs. Tho only chanco thoy havo sot to mako a halfray docont living is to havo tho first call on this.

I can scy this to you: Wo do havo noro wintor rango in Eastorn Utah than tho ranch proporty or tho comonsurato proporty will qualify or wo can vso, but, to tho oxtont that wo can uso it, to tho oxtont that our pooplo do roquiro it, wo insist that tho ict itsolf nust bo followed.

If this amondiont provails, it will bo $a$ torrivlo thing. This nocting would broak up a half of thon, or noarly half of thon at loast would go hono bittorly disappointod. Wo would bocono confrontod with suit aftor suit.

Sinco wo aro so dividod in tho intorprotation or tho undorstandiale of thoso mattors, I boliovo wo should not bind tho advisory colvittoos too strongly, bocauso wo can't agroc on dofinitions. Sinco'tho advisory comintoos aro just about as capablo of dotomining, this as it soons this body is, why not jot thon intorprot thoir actions and bo guidod by soction 3, and loavo this mattor to tho discrotion of tho advisory boards, at loast for tho noxt yoar. 
IR. TOBIiv: I approciato tho position takon by Mir. Rodd and, in ordor to as sist his in his apparont troublos, I proposo on arondront to tho notion. I vill ask that tho gontloman road tho rosolution again.

IR. BRAY: "That noithor district nor stato linos shnll bo consiclorod in detomining comonsurato proporty, and thet only customary past uso bo considorod."

IR. TOBIN: I proposo tho following ancudront. Add: Subjoct to tho discrotion of tho Mdvisory Bonrds.

IRR. CHRISTWNSE: I will only offor a fow ronarks. Our original notion and the addition that wo offored -- vo have in mind to attcnpt to protoct tho littlo ranch ormor who noods tho public connsin adjacont to his farm lands, a man that is too soldon roprosontod in theso kind of nootines, and whoso noods nro too soldom oxprossod. So I porsonally would liko to sco this accoptod as offorod at tho prosont tiro, without any arrondronts.

IIR. COX OF UT:H: It scons to no that vo aro placing so many niondmonts that it is bocoing confusing vithin tho ninds of a lot of dologatos in attondanco ard also, in ry opinion, wo aro still prosing tho buck on to tho noxt follow. Wo aro passing tho buck right dorm to tho gdvisory boards aenin and looving then to stand tho brunt of ill-fooling of tho pooplo vithin tho distriot, and I an hoartily in favor of puttinf to th into this, as Ifr. Carpontor statod this noming, and making it so that wo will havo sonothing definito to $G 0$ by, and I vould liko to soo theso mules ond rogulations road so that thoro will bu somo cloar dofinitions and sono cloar undorstandings by which the advisory boards in tho rospootivo districts night pass on applications.

So far as concorms tho. "within, and noar-nearor-nourest" anondriont, I an hoartily in favor that the componsurato proporty within tho district havo tho proforonco.

MR. CARPEITER: Wo aro now dobating whothor district and stato linos bo sonsidorod, or only custonary uso.

MR. OLIVER LEE OF NEW MEXICO: It soons to no that, up to the prosont timo, that tho most objoctionablo fonturo of tho substituto rosolution, wo aro ovorloolsine tho fact that, if this substitutc rosolution of rorod should pass, wo havo dostroyoa tho valuo of all cormonsurato proporty.

Wo of Now Mcxico, of courso, placo a groat doal of veluo on proporty right, but wo don't go so far as to say that priority should bo considared without it is attachod to cornonsurato proporty. Now, if this substituto rosolution passos, thon you havo destroyod all comonsurato proporty, and it is absolutoly contradictory to tho spirit and word of tho Taylor Grazing $\Lambda$ ct.

IRR. LES OF IDAHO: Idaho didnt think it rould havo to say anything on this quostion, but wo gavo considcrablo thoucht to this and had tho brightost riinds of Idaho, as woll as tho practical stoclanon of that district on this particular question. Wo vrould liko to road our rocomnandation again:

Rosolvod; by tho stoclmon of Idaho: that, whoro a man bo detominod as a CInss $\Lambda$ applicant, undor Subdivision $\Lambda$ of Soction 1 , that such right bo rooognizod in contiguous or adjacont districts, it havin boon spocifically undorstood that stato boundarios and stato linos would not jooparlizo tho customary uso of the rango.

IR. MCFLRLANE OF UTLH: In adding to that rosolution the part that wo boliovg that proforono o rights should bo givon to pooplo rumning livostock and orming ground within tho rango district, and should havo tho first proforonco right whoro ho had tho prior usc.

That is only to protoct tho small ranchor. It is not going to intorforo with shoop coring fron Colorado to Utah or from Utah into Novada, or Idaho into 
Utah. It is just to civo that protoction. I went to say that the first rosolution that us offcred thet fomod the Taylor Bill, barm thon as tho Colton Bill, ims that ro beliovod tho first proforcnce richt shuld bo givon to tho pooplo living in tho rango district, and that right shoulc ronain :ith tho cousunity. Just lil:o tho wator vith tho land.

If mntod to Got arry from tho prectico of whet tho forost servico had incuguratod, and this is not going to intorforc vith any of your rijts, vith any of your proferenco right, unloss you aro ono of those nonads or theso follovs that run all ovor the country.

I think that you poople all feol that we ought to protoct thoso small ranchors tho havo livod in tho rango country, and that is why ro added that part to tho resolution.

IR. VILLIi:S OF UTiII: I ariso to support tho orifinal notion and render my opposition to the substitute for this renson. Iir. icirrlano has statod to you we have cone hero to try lo livo up to and carry out the int ent and the purposos of the Taylor Grazine ict. It tells no, in these rords, thnt, as loni as thoro are plonty rances availc.blo, then it is acuinisterod to all, but in caso of ranle shortage, then it tolls no that those nearest in point of cistanco and accessibility shall be civen preferonce, and that is what $i$ beliove in, and that is what $I$ an going to support. speaker.

IRR. DORRIS OF CiLIFORIIA: I rould lile to second the statenent of this last

IIR. TOBII, OF INVIDis: Fron the romirks mado a feir minutes ato by some of the menbers here, that old büaboo is raised up again, obout the "bif Guy" Gobblint up the little fellow. I an on a board. Te passod on 315 applications, had.possibly fivo or six appeals, and took caro of all those appeals ourselves to the satisfaction of the person that ras appealini,. I nova, at this time, that the notion mado by the gentlesion from Colorndo, which I understood as a substitute, bo made the original notior.

ITR. C:RPNITER: Lre you reacly for the question? Lre you roady to vote on the question that tho substitute be made the orifinal notion, that district and state lines be disregarcled and that prior use only be oonsidered? Do you rish more discussion?

$\mathbb{R}$. COX OF UWiIf: It seans to ne that this is simering dorm to policios that you ordinarily find in a polcer gaile. The Gentlentan froil Nevacla stated that they passed on 300 applications in their district. I rill raise the ante. In our district, ve passod on noarly 900 applications. In passing on those applicntions, we kept vithin the spirit and intent of the orifinal paylor Bill and following the regulations that vere issuod for temporary license, and I vish to nalce this statoront, that I bolieve that ninoty percent of the applicants that receivod their liconses vero satisfiod vith the way ve passod on ther.

IR. MPMIS OF ARIZUIN: I an opposed to this substituto notion beconing an orifinal notion. I'feel wo should support tho orifinal notion. If we go back to this substitute notion, we are throving avay a yoar's irorle. We are going richt bnok to where re vore when this bill. was created. le are defeatins the purpose of the bill. That is what has killod the range. We are going back to "dog-eat-dog". Ho have already done that until this country is killed out.

This Taylor let vas framed to protoct $u s$, and $I$ an in favor of the original rotion. I call for the question on the notion.

IR. FR'NCIS OF UT:H: I an opposed to tho substitute notion for this reason, that I thinl: it conflicts with the past policy ve have adopted undor "Policies." We put comensurate property above prior use; now ve come back, and, urder the substitute notion, vish to put prior usc over that cf comensurate property irithin tho district. For that reason, I wil opposed to tho substitute notion. 
$B-32$

IR. HUTTON OF IONTANA: I simply rish to state that, if you pass this substitute notion, you absolutely kill our district.

MR. CARPIITER: Are you roady for tho question? The question will be on the substitute motion to disregard state and district $I$ ines and observe customary use subject to the disoretion of the Board. Only the delegates vill vote. Those in favor vill signify by saying "aye"...... Opposod, the sane sign...... The "no's" have it. Do you vish a division. We vill poll the delerates if you vish a division, and vote -. each man one vote.

If thore is no request for a division, the substitute motion is killed and wo will proceod to consideration of the original motion, which $I$ will reread.

Resolved, that dependont properties be sepnrated into those within or near a district and those not so near the district, fith first preforence to be givon to the oimer of land and livestock whose ormorship depends on the use of public lands adjacent to his property and tho has had suficient prior use.

MR. TOBII: I nove another amendnent. Strile out the poriod on the last line and add the folloring: Subject to the discretion of the Advisory Board.

IIR. CARPIIITER: The anendment is offored that the addition of the words, "subject to the discretion of the advisory boerds" bo added. Is there a discussion on that amendment?

Are you ready for the question? Those in favor of adding "subjeot to the discretion of the Advisory Board" vill simnify by say ing "aye"....... Those opposed the same sign........ vill read the motion again, then I vili read the addition whioh is proposed as an amendment.

The motion is: "Resolved, that denondent propertios be soparated into those within or near a district and those not so near the district, with first preferenoe to be iven to the ornier of land and livestock whose ormership depends on tho use of publio lands adjacont to his property and who has had sufficient prior use."

The anendment is: "subject to the discretion of the local. Board."

VOICE: I rould like to have this undorstood, that only qualified men have a right to vote.

IR. CARPENTER: Only qualifiod delegates have a right to vote. Do you wish, the delegates pollod? The Chair vill call. for a revote.

VOICE: I propose that you have them stand so they can be identified.

IUR. CARPIIYTER: That is a good suggestion. Those in favor of the amondment adding the vords "subject to the discretion of the local Board" vill stand.....". Those opposed to the amendment vill stand.....

VOICE: I vould lilie to ask you if wo knew what we vere voting on. I want to lnow wether we vere putting teeth in the law or taking it array. I think when we add that "subject to the discretion of the Advisory Board", we are taking the teeth out of the law.

MR. CARPTITER: Did you all understand that when you voted?

SEVIRAI VOICDS: Call for another vote.

in. TOBIN: So long as the opinion is to ask for another vote, I wish to ask for another discussion. 
MR. CARPENTER: I vill read the original motion and the amendment, then call on Senator Tou in for his remarks. "Resolvod that depondont propertios bo soparated into those vithin or near a district and those not so roar the district, ivth first preference to be given to the ormer of land and livestock, wiose ormership depends on the use of pubiic lands adjacont to his proporty and rho has hed suficient prior use." "he amondnent was to add the rords, "s ubject to the discretion of the advisory board".

IR. TOBII: Speaking upon tho amendment, I don't believe thore is a man vithin the sound of ny voice but what has had his application passed on by the local members of tho alvisorr board. You vore satisfied. You elocted those men to pass on your applicertion bevause you lnew they rero familiar with your conditions that existed in your country.

Therofore, why not let him continue. Go ahoad and kill this sunendment if you rant to, but I ari gojng to toll youl the advisory board is going to lose tho oonfidenoo that thoy have in you, and you are shoring that you have lost the confidenco you placed in your advisory board.

IR. INILSOI OF UTAF: I riso to support the amonduent. I think vo have already granted you just that you havo aslied for. Theso advisory boetrds all alono the Iine have considored, as the first Class A applicants, the men who lived vithin the district.

Mr. Carpenter reported that only 2 or 3 percent came back on the appeals, that vere dissatisfied. I think vo have concoded to the vishes of these men who live rithin the district, given thom what thoy have asled for.

We are ready and villing to recognize them as class $\Lambda$ applicants coming ahead of the rest of us. What nore do you vant?

MR. WHInNRY: A good many of us have been asking for a little bit more pover as advisory board menbers. Dvery novo of this kind increases the powers that $: e$ have and the rocoguition it has given us. $i$ can't see any ham -- in fact, I think it is a good thing to support the emendment.

IR. WYATT OF COLORADO: This morning, it ras the conscnsus of opinion anong these delegates that home rule prevail. Somo of thom have apparently changed thoir idcas since tho morning session. Why take the control avay from tho advisory board now if, this morning, they vanted it. I don't think that some of the gentlemen who voted against the amondmont realizo what thoy are roting on. If we are going to have homo rule, why tio the hands of the advisory board?

IIR. GARDNIR OF UTAY: In Circular 2, did you have it writton there "subject to tho discretion of the advisory board"? Wasn't it understood. Didn't vro act on those applications according to Circular 2? If Circular 3 comes out, do vo need to have that tackod on there? Isn't it subject to the discretion of the advisory board rithout those additional vords?

MR. IEDLIN: I am the man that asked you if you knew what you were voting on. The Taylor Act has givon us something to fight this irth, a lav that we can go by, and, if we had those words on thore, "at the discretion of the edvisory boards", it is going to leave it up to us to docide that ourselves, and, othervise, if it is mandatory, you can say that "you can't come in if there is no room for vou"; if there is room, we aro going to lot them in anyway. lir. Carpenter said there vere only $2 \frac{1}{2}$ percent of the people not satisfied. If they are not ontitled to go in thero, ro are not going to let them in, and re have the authority to do it irith.

IIR. IE' OF IDAHO: I have alvays been informed that these rulos and regulations wore going to give us fellors from the vest some latitude and consideration. There is just one man that can got hurt in any rules and regulations that we make here, and that is the bona fide stoclanan who has put his lifetime in making a set-up to run stock. 
In the state of Idaho, the district already in and both districts in contemplation, the boys pass thru in tro or throe districts, they have had this sot-up two or throe jears, what wo call a 12-months set-up, they trail back thru one and into another district for thoir surmer range.

Wo feol, in Idaho, that re know those conditions and wa aro not afrajd to take the responsibility of passing on those fellows and all locoting thern into the class that they belong to. This morning, it ras the intontion ailine tyms to pass this back to these boards. So far as we aro concorine, in the nanacement of the public donain, if we keep as much pover as we can at home, wo are able to solve these problems to tho bost advantare.

On all tho applications, as you said here, these boards passed on them, and $97 \%$ of them vere right and fair. These conditions that seem to affest, thes9 people in Utah and Arizona, that thoy are talking about jockeying for "ine advintage of one or the other in those districts, don't apply to our districts up there, but ise do feel that ise don't vant anybody in Arizona or Nor liexico or Utah to make an arbitrary rule that is going to telI this advisory board up in Idaho who we shall recognizo and tho wo shall not.

Wo are anxious that everybody shall be fairly treated but, on the other hand wo don't beliove there is a man that uses this range, and was using it before the Taylor Bill ras passed, that his investment should be jeopardized by any rule that is made to it any particular country. We feel very strongly about it and I don't believe there is any man in this delegation here that rould vant to oast any reflection on himsolf by acknowledsing, before this bunch, that he was not able to pass intelligently on any application that vas brought bofore him.

Idaho is in favor of this amondment, for the reason that we foel ve are more capable, have more knowledğe, understand oonditions, lnow the applicants personally, and ve have more ability to pass on those than anybody else vithin the vestern states.

1iR. CARPFIFTER: The Chair will restate the question to be sure that ereryone understands it, then, vith your consent, it will be put to a vote. The question is whethor ve vill add the vords "in the discretion of the local board" to this resolution that was originally introduced:

"Resolved that dependont properties be separated into thoso vithin or near a district and thoso not so near the district, rith first preference to be given to the ormor of land and livestock those ormership depends on the use of public lands adjacent to his property and tho has had sufficient prior uso."

And the amendment adds: "suoject to the discretion of the local Board."

Those in favor of the amendmont to add those four vords vill signify by say ing "aye"...... Thoso opposed signify by the saine sign......

I vill first talce a rising voto on the division.

INR. TAYLOR OF NEW IEEYICO: Point of information. Would adoption of this amendment stop any right of appeal above the advisory board?

MR. CARPINTER: No. It yould have no effect on that. All thos $\theta$ in favor of this anendment will rise.

VOICE: One question, IIr. Carpenter. Without those vords, vould that power bo taken arry from the advisory board?

MR. CARPMITIR: No. It would not mako the slightest dirforence.

(Count is made by $\mathrm{Mr}$. Carpenter of those standing for the rising vote.)

MR. CARPINTER: Be soated. Those opposed to the omendment stand. (Count is made.) Bo seated. Tho amendmont is lost ... vote is 82 to 54. (Applause.) 
MR. CARPINITRR: Discussion on the original notion is now in order. Aro you roady for the quostion on the original motion? I rill reroad the original motion vithput the amendnent vilich has now been lost:

"Rosolvod that dependent properties bo soparated into thoso within or near a district and thoso not so near the district, vitil first preforonco to be given to tho ormer of land and livestock whose cimership, dopends on tile use of puilic lands adjaoent to his property and tho has had sufficient prior uso."

Are you ready for the question? Those in favor signify by saying "ayo"..... Opposed same sign..... The "ayes" havo it. Any further discussion?....... Any rom quest for division?....... It is so ordered.

We nov oome up to the quostion of fees.

IR. BRAY: Resolved that fees of $5 \%$ per hoan per month for cattle and horses and If per head per month for sheop and goats be charged for 1936 licenses.

IR. CARPINTER: Tho motion is mado that $5 \not$ per hoad por month for cattlo and horses and 14 per head per month for shoep and goats be charged for 1936 liconses. Do I hear $a_{1}$ seoond to the motion?

VOICE: I second the motion.

IR. CARPDITER: Discussion is in oyder.

MR. NIELSON: I rould ike to amend that motion by cutting it in tro $\mathrm{m} I / 2$ cent. for shoep and goats per inonth, and 2 ? cents per month for cattle and horses.

VOICE: Seoond the motion.

VOICE: Vill a further anendment bo in order. I rould like to malie a motion to malce that $5 \phi$ on horsos. Othemise I ain in favor of the motion made by Mir. Nielson.

MR. CARPENPER: Will MN. Nielson accept that amendment?

IR. NIELSON: ẎS.

IR. CARPIITTR: The mendment is row $I / 2$ cont on sheop and goots, $2 \frac{I}{2}$ conts on oattle, and a ricklo on ponies.

VOICE: Do I understand that this is the assessment for the advisory boards or tho grezing fees.

- IRR. CARPEITPER: These are grazing foes that are to be chargod for tho issuanc of licenses. They havo nothing to do with assossments.

VOICE: When rill these fees take effect?

IRR: CARPEITER: They vill take effect as the 2936 Iicensos are issued... As to the payment, I could not say, but in some roasonable mamer.

MR. COX OF UMAH: I vish to make an anendment to the emendinent to the anendment, and make that $2 \frac{2}{2}$ cents on goats.

IR. CARPEITPR: That motion is out of order. Any discussion on the amendment to the motion?

VOICE: I take it that thore is an attitude or foolins on the part of the edministration that the stockmen are villing to underrite the appropriation of tho president, something like $\$ 12,000$. Doesn't that require an anondment-as rom commendod by Colorado? 
MR. CARPEITIR: The anount recommended by Colorado vill raise ebout half the amount necessary to pay the expense. The amount in the amendment rill raise about one fourth of the amount.

IR. NIILSON: Utah, then we came in vith our rcoonmendation, recommended that feo, but it should not tako cffect until tem permits aro issuod, and nor the Chaiman rather brings that into my amendment for this ooning year.

MR. CARPTITTER:- I beg pardon, Mr. liiclson. I vill rostato that amondment. $1 / 2$ cent por month for sheop and goats, 2 conts per head por month for cattlo and 5 cents per head por month for horscs; wion term pornits aro issued. That is an inproper anondmont to tho original notion, wich had to do only with licenses, thereforo it will have to come up soparately, and ro will consider the original notion concerning licensos, which vas a nickle on cattle and a penjy on sheep. All those in favor of the original notion, sienify by saying "aye"....... opposed same sign....... Do you vant a stailding vote, nore discussion or delegates polled?

MR. TOBIN: We have not had the opportunity to discuss the original motion. $5 f$ a hoad a month on cattle, to the Novada rancher, is exorbitant. You can put a oow dorm thero and it vill starve to death. I admit our ranges are moro or les's dopleted. Wo are just making a living. lie can't afferd to pay a nickle a head on cattle. We aro indebted now to the RPC and all the rest of the alphabet. I am opposed to it. I hopo, this motion is dofoated. 'I aln in favor of the amendment to the motion.

IR. CARPENTER: The point is well talion that the voto ras put prematuroly. It was put, horever, in response to constant cries for question. I feol that all phasos of this should be fully prosonted and then, whon vo vote, it might bo best to poll every delegate. For that reason, the Chair will rooomnend furthor discussion on the question of fees.

1.R. LUBIIIT OF CALIFORIIA: I can't see where you fellows have the argument that $1 \&$ a head for sheep and $5 \%$ for cattle is crorbitant. If you have got a thousand head of shcep, you only have to pay this governmont ten dollars for those sheep and, if you have got the food, I vould like to know where the excessivo figure comes in at $I \&$ a head. I can't seo it.

And the same with cattle. If you fellows have got so moh cattle that you canst run them on that range, why not cut down the eattle. There is no money made on running cattle on a range whon vou haven't got. the feed. In the lio jave district, California, we are not running more than the range vill run, and ve are viling to pay $10 \&$ a head for the oattlo, for the feed re get, and $2 \phi^{\prime}$ for shecp.

I an viling to stand rith the statement of the Colorado man, of fivo to one and I think that is reasonable enough. The first thing you follows know, this vill go baok, and those eastern scnators vill say, "If you are getting nothing, stay off." We vill get into the same position that we vere at tho time of the forost service. You lonow the trouble wo got into thero. We had to come to Salt Lake about oight years ago to a grazing conferenco and fight this thing because they set the prices up so that vo could not pay and run on the forest reserve - cost you more than running on this public domain.

I kov that to be pretty vell true of a desert. You gather your cattlo at the vaterholes and herd your sheep, whether you are on mountains or publio domain and I can't see whero that $f e o$ is going to hurt anybody. The trouble is, it looks to me like you have got too many eattle and sheep on the rango and they are starving to doath. Put the cattle out that the range vill stand, cut dorm your numbers and you vill make more money on them.

I have lost moncy in threo or four years, but I figured this feed out and I am villing to pay for it, and I could have paid for it in tho last fivo yoars, as 
bad as cattle vere. It's the vay you handle your stock. You have got too many on the range. Cut thein dovin and you vill get sonewhere.

1.R. WAJTSRS OF MOMIIG: At tho present tine, wo a ro exoeeding our linit when to offor to pay anythins, booauso all this ought to bo on a something for something basis, and, at the present tine, we are not rocoiving anjthing, and thero is no assurance ve will rocoive anything other than exercising on the rango for tho next six months. Wyomine rangos are terribly, depleted. Wo applied for liconse on the assumption that all livestock must nocessarily be includod in liconses wilch vero on the range in 1934. is a restilt of that premise, wo ordored licenses for sone 90,000 head of sheep and a great nany head of cattlo.

Wo lenor, beforo any foasiblo solution can be arrived at, that a groat many of those stock have to be takion off tho rango. If there is any fee to bo chargod, the Hyoming delegation feels it should be a nominal fee, enough to take care of the administration until we get on a basis werc wo know where ve aro going.

IR. TAYLOR OF WWW IIEICO: I cán't got together tho speech we hoard here this morning about the fat cattlo of foming, and tho ploa for free range today. (Lauchter and applause.) I ranohod dorm in Tezas and I paid 50\% a head a month pasturago on cattle and 10\% a head. on sheep and ras glad to get it. Wo have heard hore, ever since we have becn here, about the burden of our taxes and the burdon of our grazing fees and so on. It is truo vo have plonty of taxes to pay and plenty burdens to carry, but the anly people I know of that do not pay any taxes are on rosorvations and I.don't rant to be cn a rosorvation or a rard of the Goverment. I as roady and willing to pay what is suggested by tho gontioman from Colorado.

IR. WHINITRY: I am in favor of the motion as mado, but I still believo that it should be on the condition of pemits boing is sued as rapidly as possible. I feol that the jajority of $B$ oards in colorado aro ready to cominenco right now on issuing perinits. I think tho foo is not excessivo. In fact, as well stated by you, it does not cover the ontire cost, but I feel aiso that a good part of this cost of administration should be on Unolo San's shoulders, if you please, because you and your ablo assistants aro going into the work of conservation. You are saving the forest. You aro doing a lot of biological work --

\section{IR. CARPEITTER: Not mo -- not mo.}

IR. MIINIERY: And, by tho vay - y you may laugh at this $-\infty$ you should do a lot of roveretation, and I boljeve you would bo doing mighty fine vork whon you kill some of these rodonts. I think thot is work that belon;s to the Fcderal Government and these stoclenen should not bo called upon to pay it. It is improvins the rango, it is true, and the time vill come when ve can afford to pay hore for theso grazing privilegos. Look at the little colony they sont up to Mlaska.

\section{IR. CARPIITIR: Wo vill have to stick to tho question.}

IR. WHINIJRY: We vould like to havo a littlo govornment monoy spont in improving these rances and I think it is only fair it should bo donc. I still return to the fact that I believe that the issuing of the term perrits should be comenced at onc 0 , whore boards aro ready to issue them.

IR. CARPIITRR: I might stato, in explanation, that the Federal Goverment spent in excess of two million dollars in grazing camps this year, nono of which is considered in this budget at all.

- IR. HARDII OF INOTITIA: In rerard to the quostion before the house nov, the proposal to lovy $5 \&$ a head per month on cattlo and $1 \&$ a hoad per nonth on shcep: In lontana, io have a littlo different situation from what you non have. Up there we have not only got our Taylor Grazing districts, but havo also organized grazing districts under the state lav, vithin that grazing district. We have set up in the state of Montana a frazing comnission, and the funds to support tho grazing 
comnission must cone from an assesment on stool lie have alvays paid $5 \neq$ per head on cattle and 1 \& por head on shoep to support the grazing condition of lontana. A few years ago, our renges vere in good concition. At the present time, tana. A fer years ago, our renges rere
they aro depleted. If tho adrinistration of the Taylor Grazing $\Lambda$ ct vill bring
those rnngos bac! to where they vere a few years a.go, we could afford to pay considerably moro than $5 \&$ per hoad per month on cattle and $1 /$ per head per month on sheep.

In order to facilitate the Taylor Grazing poople in putting their program into effect, we think we can viel: afford to pay this lovy of $5 \phi$ per head per month on cattle and I\& per head per month on sheep. I an heartily in favor of it.

IR. WATT OF UTAH: Conditions in Utah and Neveda aro entirely diffirent from that they are in Ce.lifornia and some of those statos. Ve have absolutely no shorts when wo go out on the desert in liovada from Utah, if rro are gojng to roturn vith our sheep, rithout giving them supr lcnentary feed. If: the Taylor Grazing Act could increase the feed and chango the tcaporature so re rould not be subject to snorstoms and be buriod once or tirico in the irinter and be conpelled to go to a railroad track and ship in to a hajstiok, thon probably ve could afford to pay $1 \not$ or $5 \%$, and vo might bo ablo to raiso it, but: in view or tige present conditions as thoy preveil in Ilevada and Jtah, that charge is oxcessive, and In favor of the recominendation made by the Utell delegation, that re pay $1 / 2$ oent per head for sheep por month, and $2 \frac{2}{2}$ cents on cattle, and ro only pay that when the torm permits are is sued.

IR. HOOIJAY OF COIORADO: If this thing is not worth the cost of administerIng, is it worth administoring? Let's drop it if it is not worth what it costs to administer it.

MR. ISALLFFEY OF COLORADO: Iy experienco on this grazing conmittee is rather amusing. I sit here and hear all this argument pro and con, but. when you start to take one of thoso licenses or perinits airay from one of these mon, you reilize the value of it. It becomes very valuable at that tine. lany a fosd ingl has gone to destruction trying to get something for nothing. I foar that is were wo are going to wind up if we don't pay for what ve get.

GENTLEIIAN FROI: OREGON: Wp, as a solected group, are asking for the privilege of using this public domain. Wo are asing for it to be polioed. Now ve are not going to pay - re are renigging. If wo expeot to uso it and expect it to be protected, I think it is only just to pay a part of the oost of administration.

MR. BALLARD OF OREGON: I just went a little more information. Whon this is placed on a monthly basis, and if we had a pemit wich would be good for eight months, vill wo be charged the full eight months whether we use it the entire time or not, or six months, or whatever the time might be?

MR. CARPEITSR: The question is raised, if tho pemnit is issued for a term of months -- for instance, oight months ... and then not used for that term, as to whether the charge rould extend for that period. The answer is that it wovld not, that the Board oould talie oare of recommendations for the non-use of a peiThere is one other item that is most important, in these checkerboard as ons whore the range is capable of running, say, a thousand head, but only 40 percent public what it vas, because the Govermment rould have no right to charge for other lands run over in that district. Doos that answer your question?

IR. BALIARD: Hardly. I ranted to follow something a little further. We ould lile to use the range in our locality six months, but at this time ve can't uso it over four, and just vanted to lenor whether we vould be stuck for 6 or 7 , or get off for four.

IR. CARPEITER: It would depend, of course, on tho amount of available rango. You are in a rather difficult pesition. You are all stock users. You are going you are not here, hovever, considering this from 

question comes up why give half of it back to the counties. Gentlemen, whenever you learn that half of it comes bacl: to your counties, if a comnittee of you users are in thero, before the county comissioner, and say, "to have put so much money into your coffers this month, and ve vant tho levg cut dorm in the degroo that that amount equals" ... if you don't do that, then you are not performing your proper duty as a vatch-dog of the treasury.

There is no reason to let the noney go into the county treasury. Malne thom take it off of your tax on real estate. You lnow, if you ask for it, you will get it. You vill not get your taxos cut dorn if you don't get on the job. I feel that this addition to tho local revenue, altho in oregon and Nevoda it rops direetly back to the districts, is fair from tho national point of viov, They are not trying to keep any of this jnoney in their coffers; they are turning it baek to the place from which it eamo and, if it supplants taxes on real estate, it should really supplant them.

On the other hand, if you have some other venture and vant it to go there, you can do so. Othorriso, you can roquest your coulty cowmissioner to let it go where you want it. Taxes vill. go highor and higher unless somebody objects. This is one method of having the stocknen object. That is the only explanation I can givo on that feature of it. The 25\%. I vas assured, rould be used for the improvemont of the district.

MR. LUBIIN: The statements nade by Ir. Carpenter are true. I an one of the commissioners in California. We have a budget system set up and, the more money ve can pull dorm from the forest service and from other sources, the loss the tax rato is. I am not here to boest about that, but ve are only second or third in the state in my oounty, on tho tar rate, and re vatch overy angle of . the producer, whether cattlemen, sheepsen or minors, or whatever it is, and thonever ro can get the money in from outside scurces, wo do it ... for instance, the gasoline tax. We used to havo a tar on roads; that has been cut dorm, but the taxes on roads cut doin tho real estato property tai. Our budget is such that wo can only spend -- if vo spend a thousand dollars, say, as an illustiation, on roads for the fiscal year, we can only raise that buiget $5 \phi^{\prime}$; it don: $t$ ilake any difforence; if more of this money camo in froul an outsido sourco, we could not spend more than a thousand dollars plus tho 5\%. So I can not exictiy agree vith lir. Dorris on it; that is, double taxation. Wo arc getting something vorthwilo and I fool we should pay for it. If it is not re thihile, we shouid quit.

IIR. CONOVIBR OF UTAI: I vill tell you why our Utah boys aro opposed to this fee: because vo feel that the Department of the interior has nothing te soll us, only operation. In our district, ve lovied this sano lind of tar that we opposed for a seasonal operation, and we aro going to operate our district for $1 / 2$ cent on shoep and 2 唉 cents on oattle and horses. Wo are going to operato for six months for that amount. If vo rould make that amount for a nonth, that vill increase that fee six times, and we feel that all ve should pay at this tirie is the operation fee. Laybe a lot of you fcllows graze in a fatter land than ve graze in. Our deserts are depleted, not from overgrazing but from drouth. We have been burnt to death for yoars, and, if ve can onco $g$ ot a normal amount of moisturo, vo are villing and glad to pay for overything wo can get off of public domain.

I think that this feo should bo as wo have stated, that tho Departmont of the Interior should carry their part of the expense, and let the people using tho domain covor the operation cost, and I beliovo that this foe vill cover the operation cost. Our sheepmen in our districts lose on a herd. A vintier herd of sheep runs around 2500 to 3000 shoop. Our men lose on a herd arl averago of 400 head of shoep on that liord in one soason. The cattle lose the same proportion. We feel ve are not in a position to go ahead and pay this feo now because we have this advorso condition. We would like to have the foe held nominal, on a sliding scalo. Why not start easy and give us this nominal foe, let it grow as tho oountry grows. Let's pay for what tho country produces.

IR. OLIVER LEE OF NEW HEWICO: I, too, join you in my sincere belief in the integrity and faimess of the livestock raisers of the vrest and publio domain 
$B-41$

states. I don't lnow how you fẹel, but I feel ro have been just slipping a little bit. I folt that all of the livestock raisers vore men of character that could detcmine any question that comes before them fairly and justly, regardless of their personal interest. We have boen encouraged by the acts of our advisory boards up to this prosont time, but I feel that they are taling an unfair position here today.

I an not fully advised as to the oost of loasing the school lands in the different states. I am not fully advised as to the prevailing amourt of lease charges on privately omed land. I am not fully advised as to the forost foos charge, but I feol I could say irith confidence that the fee set-up in tho prescnt resolution vill bo less, as far e.s a grazing charge is concerned, than is charged on any of the other lands vithin their respective states, and I thirls that they should be fair and just and not attempt to got this land for any great amount less than thoy pay for other lands.

MR. CECII OF OREGON: I fail to get the vienpoint of the gentlemoin who spoke about doublo taxation. The roason I mention that at this time, the subject has cone up repeatedly since ve have been hore. As I undorstand the theory of this Act, we arc all hopeful thet we are going to improve the rango. Ultimatcly, it is going to be worth the fce. The fee oollected at this time vill simply bo an investment toward bringing about this desired result. As to what bocomes of that money, it is beside the question; it seems to me that is really confusing rather than clarifying the is sue.

MR. CARPEITER: I might state this: We aro trying to get all the facts in front of the delegates: Senator Leo raised the point of foes on school lands. They vill run from $1 \frac{7}{2} \phi$ an acre in Arizona, to as high as $8 f^{\prime}$ an acre.

MR. COX OF UTAH: After listening to this discussion rith some amusement and some recollection of livestock meetings that I have attended here and other places before the Taylor Act vas passod and re, as a group of Iivestocknen, the people who promoted the Taylor Act and the people who aro now administering it, signed a note in blank. I lnow resolutions trero passed and I have heard livostock men say we vere villing to pay a reasonable fee for the use of this publio domain, and we didn't rant it for nothing. I have heard our congressmen who vorked for it report that the opposition from the East to this bill, part of it was because the eastern states had no state lands and, when they produced livestock, they entered into competition with livestock producod on free grazing land.

We had all those argunents to met and we passed somo/resolutions, or cxpressed ourselves privatcly, that we were villing to stand for reasonable fees for the use of this public land and for reasonable fees for tho adninistration of it. We gave that impression out. We have given it out here. Our administrator here, Mr. Carpenter, has relied upon the feeling and the information that he got from attending thoso meetings and I belicve he expects us to honor the check and the note that re signed in blank, now, and vote for such a reasorable foe for the use of this public land and for a reasonable fee for the operation of it, and personally it is my belief that the fee of $1 /$ for sheep and 5 f for cattlo is reasonablo and we should stand bohind the Department and our Secretary here arit our leader, and honor this check that ve have signod in blank today, and vote dorm the motion to reduce the foe, and adopt the fee of one to five

MR. CARPINTER: I want to say that I stuck ny orm neck out on tho ten' to two rith Congress, and I vill get her back in, so don't mind about me. I want you to set a fair foo, and I believe you will, but never mind about me.

IIR. DURAIT OF INEVADA: With all due respect to the gentleman from Ner liexioo in rogard to the character of cattlemen, and all due respoct to his seniority, I happen to come from a third generation of cattlo people in Nevada, and wo alvays selt that the cattle people vere also of good character and wo resent vory much the fact that Nevada has taken tho attitudo that wo don't rant to pay for anything. Wo vant to pay just as much as tho traffic will boar. We fool that conditions in ivevada are so different from these other states that we feel consideration should 
be given and adjust these differences to the local colittions. Wo aro not trylng to evade theso conditions. Wo are rilling and anvious to pay. Wo foel it is not entiroly fair to put a fee on us that will fit these othor oonditions. Wo want to be bohind you and support you in every way ro can. Wo bolieve the Taylor Act is a good thing, but wo do believe in faimess to the poople who are trying to malce a livelihood from it.

MR. CARPIITER: Aro you ready for tho question? The question vill be on the amendisent to the motion, viloh was $27 \%$ for oattlo and 1 . for sheep and goats, and a nickle for horses.

MR. TOBIli: Didn't you take the amendinent off?

ITR. CARPENTER: Yos, I did. That applied to permits and vas therefore rulod out of order. So, when re vote, ve vill voto on the orifinal motion, which is $5 \&$ per head per montl on cattle and horses and $1 \%$ por head per month on sheep and goats. Are you ready for that question? All those in fovor of $5 f$ on cattlo and horses and $I, f$ on shesp and $G$ oats, per montil, for a fec for liconses in 1936, will say "aye"....... Op posed sainc sign....... The "ayes" have it.

Do you wish a division? Do I hoar a requost for a division? If not, it is ordered that tho recommendation to the Seorctary of the Interior vill be $5 \not$ for cattle and horses and $l \&$ on sheep and goats. That finishes the 'four subjects ro had undor consideration here.

I have an announoement to make which vill bo of particular intcrest to you here in vievr of your recent vote, that tho first caso of trespass under the Taylor Grazing Aot has been officially placod in the hands of the United States Attorney for action. I do not wish at this time to state the name and place, but you vill all lnow about it, becauso it vill soon be out in the shape of a varrant.

MR. McTARIAAis: I havo a resolution. Would it be propor to introduce it at this time.

IR. CARPIITTR: I would like to complete the program of organization and improvemeint, which vill be conploted here with solccted speakers, and I belicve wo vill limit the speakers to not more than threo ininutes. In the matter of organization, I rill take that up in this way. It was sugfestod that it would be advisable for district boards to incorporatc, for cattlo and sheep sections to incorporate separatcly. There is nothing nandatory abcut that, but it puts you squarely under Soction 9 , makos it a littlo handier to deal under a ooopcrativo agreement. That is just a matter for you to o onsidor.

In the other matter of organization -. the fometion of state and national comnitteos -- in the absenoe of cxpress authorization to do so, I belicve ve rill loave the district oomittees as they are and, at the next noeting of official delegatos from the differont oommitteos, wo will talc up the matter of pormanent state and national committees, in order that the rampo may bo fairly reprosonted by both local, state and national conunitees, should that be your visli.

The third subjoct undor organization was the future rolations vith existing livestock organizations. I have had some talk with tho oficors of many of those associations, and it is bclievod wise, at this time, to lot that subjoct alone. Lot us approach it gradually, as vre come to it, and with tho idea that ro are not trolng to build another organization as a rival to any of those that are already in cxistence.

Are there any questions that you vish to ask before I go to the question of iriprovements?

VOICD: Associations aro recognized, such as local associations?

MT. CMPIITSR: Yes. I looked up, under Section 9, the leglslative history, into tho dcbates in the cornittee. Congross referred to unincorporated associations, and I was assured by the Solicitor that the rords "lo'cal' associations of stoclanon" referred to incorporated associations. In lifontana, it vould bo very much to your advantage to incorporate. 
MR. WALTERS OF WORIIIG: The associations you refer to can be purcly voluntary, can they not? That is, I mean, they must have no formal organization at all -- just a group brought together vithout any formal or ganization vill be re. conized by tho Department in ararding liccnses or teinporary permits?

IR. CARPMITSR: Yes. I should bring this point beforo you again. You gentlomen perform dual functions. You vill notice that, in Circulars 1 and 2 , it is provided that, when authorized, the district advisors mey act for the best interests of the licenseos in other matters than passing on licenses and rocommending special rules. Nor, you are acting as a $B$ oard of Directors, then, for a local association. The matter of these assessments brought it up before the district. The rules and regulations which will be forthcoming and which vill provide for tho method of paying tho assessments, the matter of incorporation, and the functions of the locel associations as separate from the governental activities, vill bo made very plain, and that is rhy I believe further talk about organization is a little prenature at this time.

You can sce what ve are looking forvard to is a local association of the users in each district, that vill be able to talco other action than your governmental activities in coming to assist the Dopartinonb in recommending licenses and special rules. In other vords, the associations ill take care of other matters for you.

NR. DORRIS: Vould that chango make any difiercnce in the election of your advisory board?

IR. CARPEITER: I think not. I believe it is going to bo advisable to have tho Dirootors of tho Jocal associations the same men as the district advisors, for this reason: if thoy are not, you rill get into a conflict. I seo no reason why the Board of Directors of the local association, if they vill oloct thom by precinct, and one-man-one-vote, the vay vo do you gentlcinen, why the Govemment should not adopt then as the advisors. Do you see? In other vords, that ve vould take tho Dircctors of local associations, providing thoy vore elected demociatically as you have been, and allow thern to Advise the Department of the Interior as the district advisors noit do.

IR. DORRIS: I had some experience inth the stock associations as an advisory boaxd. The Forest Sorvice held that, as long as re had a stock association, that more than $50 \%$ of our permitteos belonging to that association, that wo would be entitled to an advisory board. Things rent alon very vell for a tine, and the mombership drow out of the association $\ldots$ that is, they just dropped it .- and ve lost our advisory board.

Under this ruling that we aro in nor, every permitteo is allorod to vote and to choose his reprosentative to represent him on the advisory board, which makes it permanont, and there is no vay you oan drop out and lose this unless the Govermment says, "We don't want you," and, if we swnp over and allorr some association to select this advisory board, I an a fraid we night be on ground that is not too sooure.

IR. CARPEYTTR: I may say that this is net anything that should be "jumpea at". It should be very carefully considered by the Department and regulations sent out and discussod by you on the matter.

I have selectod eight spoakers and vill ask them to speak six minutes oach on "Inprovements", from the Advisor's point of viev - - what he thinks of the rork done in his state by aotual observation -- if ho wishes to oriticize or praise, it makes no differenco - and that ho thinins about the futuro of it. I irill oall first upon $\mathrm{Wr}$. Ilathis of Arizona. If you vill speak from your seat, lir. Jiathis, it vill save time.

IIR. MATHIS: I think, in ordor for you to approciato what the CCC camps are doing on the "Strip", you might as roll havo a little bit of history on that "Strip". It is a quite notorious part of the comntry. I have boen ranching there 
for 35 ycars and, during that 35 yoars, I think about four men have boon lilled, and I rould not stop to estimate hor many have been dam near vhippod to death. When one man ves fatally shot, ve sent a covboy to tell his rife about it. Whon his rifo met the corboy, she said, "lias it fatal?" He said, "Yes, but I think ho will be ail right in a few days." (Iaughtor)

I would just like to say that I rant to commend the work of Ir. Carpenter, Mr. Ryan and Mr. lierr. They are not trying to do this with their feet under tho dosk. I took a trip with these gontlemen on the "Strip". After telling them a lot of these blood-ourdling stories. I got them by rithout a scratch and they felt all right. We corne by a little settlement there, where they vere colebrating, and the women vere running footraces. Wir. Carpenter said, "Let's stop and see these races. So we stoppod. He said, "I'll bct on that girl in blu' there." I said, "What do you vant to bet?" Wo vagerod a little on it, and he lost his money. He gave it up all right, but he said, "I think you have beon out: here chasing the women." (Laughter)

MR. CARPDNTER: I vill say, in that little tom, thero is a surplus of shestuff nor. (Laughter)

IR. MATHIS: Gentlemen, wo approciato the vork of these camps. I just vanted to give you that little sketoh of the history of Arizona to show you ve are badly in need of this kind of work. It is work wo could not afford to do.' Wo first went out thero vith paok mules and, by donations, wo made it possible to uso buck-boards. At the present time, the CCC camps out there are going to construct good roads and they have advised vith the advisory boards and asked us to help plan the work, askod us to plan a 5-year prograin. vio told them we could plan a 10-yoar program if necessary. They aro going to build roads, trailis, fences, waterdevelopments, and vo soon hope to havo the Arizona Strip so we can pay $10 \&$ a hood grazing privileges on that.

I would like to say to the gontlemen from California, who was shooting at us a wile ago, that vo have had to take our cattle dom there to fatten thom, and pay 5.00 a month for pasture. No ronder you are so liberal about those payments.

IRR. CHRISTEISEN OF CAITFORIA: ISr. Clairman, ladies and gentlemen: When the gentleman from Wyoming this mornjing was telling about the good cattie in Wyoming, he reminded mo of an old story of a rancher wo, che day when he mode his rents, walked into a bar dealer and said, "Give mo a little shot of rre." He poured out a big drink and drank it and he said, "That's fine; that's good." I'he bar dealer thought, "I vonder that he rould say if he had a really good drink." So he put out a bottle of vory fine viniskey and said, "Iry a drink of that." So this fellow poured himself a stiff drink and drank it, and didn't say a vord, and he started to valk out. The bar dealer said, "Say, felloir. What do you think about that drink." He said, "It speales for itself." (Laughter)

Gentlemen, we have tro CCC camps in the lodoc-Iassen grazing district, District 2 in Californja. I was glad to be askcd to say a ferr words about this grazing lork. A good many come to me and esk me about it. I vill just give a little outline of the projects that ve have asked fibr, nany of which havo been endorsed and granted by the Department; 'Which projects are in process of complotion at the present time. First is ran fo examination; dotermining carrying capacity and a complete survey of range la ins adjacent to our ranches ... range cover, kind and tendency -- vater exising and future devolonmert of vater, wells and springs; etc. Second, trails and roads - - at the presont tirie, we have 200 miles of trails and roads under construction or contemplated to be constructed. Iratcr development -. we havo tro vells now operating, with 20 now locations for vells contemplated. Drift foncos .. - nany miles now under contcriplation. The boys arc maling pasts and starting to dig holes. Predatory animals .. six projoctis undor vay. In the movement of livestock to summer ranges, where the men used to start out vith cattle overnight, we are now having the set-up where we are having whole colonies benefit .. the velfare of thoso in that neighborhood. Stock driverays are being located and a portion of those drivewars are being policed. Insect control is contemplatod - fire control, telephone lines, erosion control, and poisonous plant control. I thank you. 
MR. ZAPP OF IDAHO: Wo have got tro CCC camps in Idaho, doing about the same rork as in California, and ve approciate vory much that thoy are doing.

MR. MONTGOLPRY OF WONPANA: Range improvements and suggostions for its solution and preservation. Wo in lontana foel that it requires a rango control program which necessitates soveral very important features first of which is the devolopment and control of stock vater supplies. Those are many and varied in nature due to loeal. conditions and supplies that are available to develophent and to control.

1. Dams and reservoirs of varying sizes and for varying purposos, The storage of water for use in its stored location presents many problems for inany sizes and types of roservoirs and dams -- you must roadily see that in ary lendeavor to sooure vell distributed vater supplies locul conditions and opportunities vill of necessity decide the location and type or size. Wo believe also the storage of larger quantities of vater at heads of dry streans that can bo releasod at periods to roplenish the mater holes in the stream bed belor to be a highly desirable storage. Iho further use of diversion dams or diles to distribute run-off vater over a large surface area to betiver store the vater in the soil to also offer a dosirable solution to vater conservation.

2. Springs. The development and protection of springs thru the uso of fenced earth tanks or reservoirs which can be led into service rater tanks is likewise much to be desired.

3. The use of vells in these areas where suriace storape is not availablo or not practical is still another desirablo supply o $I^{2}$ vater which if prooerly developed thru installation of snall gas engino purp units and /or vimdnills along with earth tanks for storage wilch, are then oguipped with 'service tanis filled thru valved or siphon pipos. The construction of reservoirs of all kinds jefer a wonderful opportunity for soil orosion control.

The construction of drift fences, boundary fences and as time brimges the allotmonts of the rango the construction of fencus about allotments vill ajd considerably in contsoling tho past difficulties of avergrazingo the construction of roads and trails thruout the grazing area ihero needed vill aid in sipervision and fire prevention. Tho oonstruction of coirrals, dipping vats, camp cuarters for horders must of necessity proceed vitin caution and then only when avd wore actually needed and must be under strict supervision of some orgenization such as our Montana State Grazing Wistricts provide.

The problem of driveways likewise are desirable if they be arranged and provided vith ample and proper regulations and supervision. The elinination of fencod county roads thru large grazing areas is very desirable and wherevor possible should be eliminated by tho construction of auto pass crossings and gates. The removal of old deserted fence material, old farm buildinss, the oblitoration of the old sings of farm buildings thru filling of abandoned cellars, vells, cisterns, and the like, is much to be desired. Due provision should bo made for trail pastures espeoially for stock en route to market. A concentreted drivo on rodent and nagpie control must not be overloolied as viell as the continued effort to koop dorm to a minimum of all prodatory aninals.

All the above are activities that can be carried a long way tovard, completion thru the activities of not only CCC cam?s but the camps, and projeots now going ahead under the ITP thru the resettlement division. The resoeding of abandonod farm lands, tho eradication of poisonous plant lifo, aro other inprovemonts to the range situation.

In conclusion and summary, every effort should be made to correlato tho notivitios of tho projects now going fommard under the direct suporvision of the resettlement division with tho establishmont of CCC ccinps which are making possible a now era for the poople of the state and country. 
IR. A. D. BRCNNFIELD OF HEW HAXICO: Mon the advisory boards of tho Southvostorn How Mcxico Grailng District No. 3, got organizod and sottlod dorm to vostcrn low woxico told that tho Socrutary of the Intorior had tho orosion control work program and consorvation of tho rengo $\mathrm{cs}$ provided in tho Taylor Act, placed undor tho suporvision of the Division of Grazing: ani that wo wore chergod, rith tho furthor duty of helping nako it sorve tho Puij] ic Lanos. Wo vore not too oager for moro dutios, but it this ras tho Sorretary's vishes; roll and good. We had always rantod sono control over tho Public Domain. Now vo voro gutting that, and if cooporation betwoen tho Grazing Sorvico and the ranch men would bo an aid toward protecting and consorving tho lands wo rosolved to do all possiblo to holp.

On the first of August, last your, we recoived and got uncler way throe Divi-. sion of Grazing CCC camp, all lecatod in our grazing district. Thoro is littlo need to outline just what the purposes of these camps aro .... ritu dis; most of you are familiar. It vill, hovever, bo interosting to shor to viint aruont crazint district Boards, and the ranch men, con cooporate to facilitate, tho range improvoment and consorvation vork of the camps.

In cur district, wo have boon nctive in holping to develop those projects which we believed vould benefit and bc of some valuo to the stoclmon. Our Board roccivos and makes rocoimendations. on a.1I ranch proposals subratited by individual ranchors. There are several roasons why it is bolieved this is a good practico, because of tho fact that all proposals cono bofore the Board, all selfish, intorests are minirized. Projects are approved only there there is a bencfit, at loast in varying degrecs, to tho publio ranec.

Among tho moro important projects and thosc wich vill be of a mone jminedipate benefit to both the rang $\mathrm{C}$ and tho rencher and the livestock industry might bo listed: I. Water development, - just nor this is necessarily being delayod becauso of tho fact that a dovelopment cf rater prior to the allocation of range would opcrato to complicate its adjudication. This is lending strength, to a position, well fortified, wo bolieve, for as oarly temporary allotmont priviloge.

2. Tho construction of foncos on ranch boundarics. Folloiring this, wo might list vater spreading in arcas whore the torrain adapts itsolf to the rork, and to be followed by revegctation whicin becones practicablo because of the oolleotion of a greater amount of water.

3. Thore is probably no project wich has vider sanction and greatcr general approval than the destruction of rodents and poisonous plants. This is beine pushed vigorously and ranohers in our area arc cooperating and furnishing available ranch buildings when nocessery to house the boys who aro carrying on this work.

Other worle now being dono is commity ranch roads, comocting vith the main highrays, stock'trails loading thru rough nountainous hills, and cxperimental plots for revegotation. And there is yot other vork ve hopo to get dono, as rock and concrete reservoirs in eanyons whore there is no vater, conmunity scalcs, holding traps at shipping pens, and porhaps along tho drivevay. In these three latter projects, we are firm in a position that the renchmon fumish the material.

Wo believe, with all the good boing done, thit some construotive eritieism oan vell be offered. We sugfest that some improvenent can be made in the work by more rigid supervision of the personmol of the cemps, in order that tho ineffioient onos may be veoded out. Further, that tho Sunerintendents, the technicians and foromen be in part responsible for their work to the advisory boards. If this could be done vo aro of tho opinion moro interost and efficiency will be the rosult among the officors, and the work done bo still more pormaneit and sooure.

We are oxtremcly proud of the rork dono in our district by tho EClf and glad that it is undor the control of the Division of Grazing. There has bocn oxemplary work donc and it stands as a monument' to tho Service. It appears vory permanent and no doubt rill control to a degroe orosion and redound to the benofit of the range. 
MR. MARVEL OF NEVADA: In our state we have, two or throo cCC canps, and in this conncetion I would like to compliment in. Joe Leech and his ocoms, and in woll as Major Hunt, for their efficient work.

liR. A. S. CHENSY OF EASTERN UTAH: when our board in Utah, lio. 8, learned we were to be assigned some CCC camps, vo wero very happy and have been very enthusiastic about the work being accomplished ever since.

The precodine spoakers on this subject have almost takon my power. I will Give you an outline of the projects that havo been outlined for fuiure developboen taleing in this dere idea of the active interost various. Utah stoclanen have springs to be devoloped. We hove the how have the location. of 102 seops and drillin: sites, havo outline'd poison plant oxtermination, trails, as roll as rodent control,

This procram calls for an estinated outlay of 890 -man-lays, or about I7" it years for one camp. I don't believe this progras could hevo been outlingd so rcadily, and so well, without the existime knowledge that our livestock-men had our, board nembers, the enfinecrs district and rithout the cooperation that other livestockmen have riven to us superintendent of the sch camp and various

The ECh enfineors and superintendents have atiencied our meetings regularly where we heve planned the work to be outlined ancl arrangod for men to go, on the
range.

HiR. NTELSON OF WESTERP UTAH: T. an very ruch in favor of this work. In District 2, Utah, wo have two camps - one at Joricho and the other at clover. We havo some very active superintendents in the Jericho Camp. Tho superintendents are very enthusiastic in the rork.

iTh. HINSEN OF ITYOMING: lir. Chaiman, in reporting on the improvement of our.district, District I, I vish to state that a kreat many things have beon accomplished by the CCC boys, and with the cooporidion of the Dipartment on the Grazing Division alone with $\mathrm{Mr}$. E. G. Jrovm, wo has the management and
supervision of that camp.

Ve have 196 boys there. But inspite of the fact that they were hendicapped in tho vay of oquinment and tools, the have accomplished a food deal in the way of buildine rosorvoirs or water derelopment, and that has been with shovels, picks and wheolbarrows. They hove been promiser that their July, and about threc vreels aco ther received Fins camp was ostublished in and sorapper, which they are usine in the loceting the driveways.

The board has appointed a comnitteo from the respecitve localities where they were elected. They, along with $\mathrm{Mr}$. Brom, have fone ovor these locations in the way of trails and the location of driveways. They aro putting up sign maps being prepared are remere they have been located. Mr. Brow saw that accomplished by these boys', and we fool that a great deal has boo: and will bo success. I wish to state also that a do all in our porrer to malce it a and, in the very near futuro, the building has boen ostablished at vorland, boys went into the timber and got several at worland vill be occupied. These ahead with the work. 
IR. ChFPinTER: I have a proposal that I believe should be submitted to this as oembly. It answers most of the kick that we hear on the range: That tlie Arizona strip be fenoed out, that Utah koep Wyoming out, and Colorado keep Wyoming out, and all states fence up completely and keep their stuff at home.

Gontlemen, we have divided the ten western states into three regions, and wo have vith us this afternoon, the three regional supervisors. 'First region, Now liexico and Arizona; seoond région, California and Oregon, and tho last rogion includos Utah, Vyoming and Colorado. I wish wo had the time to go jnto dotail with theso regional. supervisors here on that, work. As we do not, I will ask each of them to stand up and give us a rord as to what they think the value of their cooperation with the stoclanen and their vork with the committees. I vilit first oall on the region from lor Mexico and Arizona -. lir. Caron. Just a rord of greeting is all. I an going to call on you for, on acceunt of tho time.

MR. CARON: We have eight camps located in Hev Moxico and six camps in Arizona, which vere occupied at various dates between July and August of j936. To other agencics operating CCC camps; ve probably seoned slow in getting started. Horrever, during the last folir or five months, we expended 150,000 man days of labor on the public domain, with the following aocomplishinents:

Constructod 250 miles of truck trails. liaintainod some 500 miles of roads. Treated 80,000 acres for erosion control and flood irrigation. Built 75 miles of stock trails. Fradicated poisonous plants on isolatcd areas, totaling 5,000 acres. Gathored 3,000 pouncis of varioys sced, wich is being planted on flood irrigation projects, Construoted over 100 miles of telephone line. Trcated over 450,000 acres for rodont oontrol. Built 650 miles of fenco. Also various other oonstruction and maintenance projects, such as spring developnent, cattle guards, stock tan!s, viells, and so forth.

Have established range survey partios to check comensurate property, thene helping to speed the allotments, Constructed a peritanent type side eamp in Albuquerque for enrolleo draftsmen rho wolk in cur drafting department, malcing various kinds of maps needed by the Division of Grazing. Have developed a riobile type unit for sido camps. This consists of a trailer type littchen unit and also a trailer for bathing faeilities. With this tspe side camp, accomodating about 35 men, we expeot to bo ablo to move about nore froejy over the public domein and vilj be operated noro efficiently due to the fact that we have the men locatied near the work projects, thus elininating the travcl timo to and from work.

Wo have' sulmitted to Washington a five-year progran based on an average of 25 camps for New liloxico, and 2.1 canps for Arizona. This involves an oxpenditure, of some 10 million dollars and oovers some 3400 tormships in Nev Mexico and Arizona. Some of the contoriated projeots are as follows: 35,000 miles of fencing. Flood irrigation on one million acres. Rodont control on approximately 10 million
acres.

Assuming that all rango lands vill be, allocated during this tine, ve set up a vory extensive vater development program, which includes rielis, stock tanks, and spring develoment. Our estinate shows neod for some 1500 irells and about 4000 stock tanks. We also have various other projects such as roads, telephono lines, poisonous plant eradication, experimental plots, stock trails, eto.

Cooporation with tho Advisory Boards: "iork projects litust have the approval of the Chaiman of the $\Lambda$ dvisory Board. I'his is necossary in order to make sure that the improvements put on the range are vhat tho stock man needs and wants.

We rrant the nembers of the various advisory boards and the stockmen to suggest projects that wo need in their localities, and help us to put this progrilm over. 
MAJOR C. I. HUNT, RENO: Iir. Carpentor has rather linited the opportunity to tell you all of the very many fine things that isc havc done and rould like to do, and has linited the the discussion by ourselves to a point of a mattor of introduction and a thanking of the cormittces who have formulated these vorl: programs.

I vould like to take this opporturity to tell you, however, how the rork prograins are formulatcd and how they arc carried out. In District 2 ... I speale for District 2 only, or rather Region 2, which cmbraces the states of Calinumia, Oregon and Nevada -- the superintendents of the camps - and there are $I$ ? 0 i thom in these difforent states -- go to the comittee men and ask for their roconmendations as to the typo of work to be carricd out, the location of that work, and when it shall be carried out.

They then take these recomondations and formulate them into ia workablc progran, and resubmit trem to tho comittees, and, o. fter heving had their olray endorsod in miting on the back of the rork program, the sane is sibmitted to headquartors, when the cngineer takcs the work progrom, makes an cistinatc of the amount of material, the time element, and turms that over to the supply officer, who in turn gets out bids for tho material and gets it into cimp, and a program is then started.

I vill talce this opportuiley to thank the members of the comittees of the three states for the cooperation that they gare in the recent call for help in the expanded program over the five-year poriod. The rosuit of their work has been show by the fact that, thile the other services lost camps -- some 93 in California a lone - - the Division of Grazing lost none, and we hope can evon expand after April.

As to what is coming, what we want to do, I an reminded of the story about the negro who vas passing a graveyard in tho dark and sav a ghost sitting on the headstone of a grave, trying to light a marble cigar. He turned to tho negro and said, "Have you got a match?" Ho saic, "Io suh, I air't, but I'm gotting array from here." Hc started out ruming and, after a little whilc, looked over his shoulder, and the ghost ras right alongside of him. The negro sat down, and the ghost sat dow beside him. The glost said, "Doy, that vas sure traveling!" The negro: said, "Yes suh, and whan I gets my breath, I am going some more."

A survey with which you arc all familial has boen carried an in the mattor of commonsurability and stock vater in Pcrion ivo. 2. B rought up to date, there are completed 702 comnonsurability survcys, and 651 stock vater survers.

IR. CARPEITRR: I vish to call attcntion to the fact that we nover could have gotten to this a.llotment of range nearly as soon, had we not had available the facilities and the vorle of those camps and thcse regional supervisors.

MR. MCIIAY, SALT IMIE CITY: I just vant to say "hov-do-you-do" to you folks in my rogion. I vant to conplinent you for the bang-up job you did in aiding us to get the five-year progrem over. We are going to give you the same kind of cooperation in our part of the work. So far as we arc concernod, this work of rango improvement vill go as fast as you tant, and no faster. I vant to thank you all for your cooperation in this matici.

IR. CARPENTER: Now, I have a report from the first desert range cxperiment station in the Unjtcd States, and I vant a brief description. It is contemplated that the next national meeting vill be at Bums, Cro., so you can sce what a rangc oxporiment station for stoclonon is likc. 
- MR. CECIL, ORBGON: There is a pirst time for cverything. I have stood behind many kicking mules. This is my first oxperience behind onc of theso things. (Reforring to tho miorophono.)

Over in Iarney County, as Mr. Carpenter has said, we have a very unique situation. We have tho first rango exporinent station in the rest. This was temporarily establishod. somo time last year. A. CCC camp ras set up and, thru tho facilities of this canp, all of the work is being done, such as fencing the onclosure, putting in fences, eroctins pormanent corrals, installing scalcs, in fact, ovcrything nocessary toward a conlete livestock operation.

The idoa of this whole sot-up is to show and doteminc just what can be dono to control grazing.

Thoso of us who livo over in Harnoy County aro vory proud of this unique situation and fecl hopoful that, as a result, rango rostoration will bo hastoned by many years.

Whon you gentlomon como over to Bums, wo hope wo will havo the pleasure of showing you just that has boon contemplatcd. Wo ars proud of it, and aro satisfiod that you will be.

MR. CARPENTER: Gontlomen, at this time, I rant to call on our good friond, Socrutary Walters, and sco if ho won it say a vord or two to us.

IR. WAITERS: My statements vill bo vory short. I wish to stato that it has boon a plonsuro to have boon with you durine this nocting, and it vould bo 0 grcat ploasuro and prido if I could introducc boforo a mooting, such as this has boon, a numbor of our Sastorn fricnds, who do not ontortair tho opinion of tho stocienon of tho Wast that somo of us do.

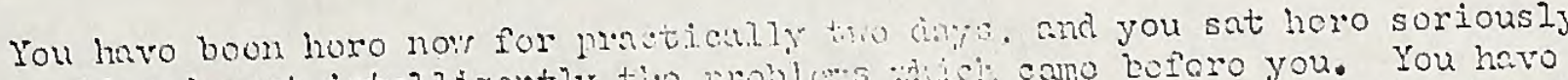

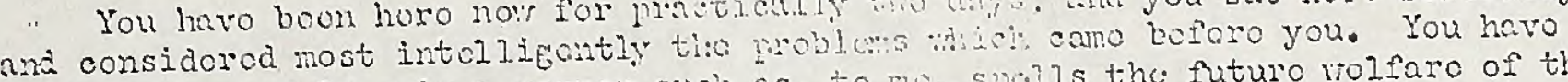
conductod yoursolvos in a manor such as, to me, spells the futuro rolfaro of tho Taylor Grozing Act.

No one can toll ino, and make mo boliovo it, thet a body of mon trho aro aocustonod largcly to the outidoors, vill subjcet ticnsclvos to two days of punishmont and imprisoment, as you havo -. I know of is nutubor of you tho havo not boon outsido of this building soarcoly sinco you cano to tho oity - and then try to convinco mo that tho mon who are to get the sorvices rondorod by tho Trylor Grazing Act aro not in oarnost and do not dosiro it.

It is impossiblo to convinco no that your atitude moans anything but your most ardont support of the Taylor Grazing Act cin tixe devolopmont of tho rango in tho Wost to tho condition in which you dosiro it so that your industry might bo omoin profitablo and you micht conduct it ...t pro pleasuro and convenionco ther. you havo in tho past.

I did not ariso for tho purposo of lining a talk ct this tine in tho day. It is alroady too late and I have had the plossure of sponleing to you boforo. All. I vanted to say to you, vith tho groatost soriousnoss and camestnoss, is that I an gratoful for tho opportunity of boing vith you and laving an opportunity to scrvo you.

Somo of thoso things, I have had tho opportunity to say to you in privato. I have not bocn ablo to shako hands with oach of you individualiy, but I should like to state to you, as a vholo, tho plcasuro I have had in the mocting and the manner in which you have conduoted yoursolvos, and my confidcneo in you and in tho futuro of our prograr.

I thank you. 
$B-51$

MRR. MoFARIAINS OF UTAH: I just vanted to offor a short resolution. I boliove I can malco you hoar, booauso tho "miko" and I aro not hording togothor vory voli.

To tho Honorcblo Harold I. Ickos, Scerotery of the Interior, Wesiningto:n, DC: Inasinuch as tho Taylor Grazing Act has to do with lauds siturtod in the "fostorn pert of tho Unitod Statcs and usod by citizons of the Wostcrm States and only citizons of the Wostorn statos aro thoroly fnuliliar vith tho conditions surrounding tho nocossity for tho Trylor Grazing lot and essoitinl to its propor codninistration, and,

Whorcas, this conventio:1 of delogates roprosonting tho Wostorin Statos which aro intorcstod in tho adninistration of the Taylor Graing Act, has bucn dirocted and conducted by the IIonorable T. A. Walturs, First Assistant Socrotary or the Irtorior and Mr. F. R. Carpontor, Director of Grazing, and,

Whorons, tho dologatos assoliblud at this convuntion from thoir contacts with the abore noncd gortlcnon roprosunting tho Departmont of Intcrior bolicve that thoy have a thoro undorstanding of tho conditions riquiring tho passago of the Taylor Act nocossary and for its proper adninistraticn,

Now, thorcforo, bo it resolved that tho dolegates irosunt at this convontion hold at Se.lt Lako City, Utah, on tho thirtocnth and fourtoonth days of January, 1936, do sincorcly thank tho Socrctary of tho Intorior for solocting such ablo roprosontativos of tho Deparbincut of Intorior and non who aro so thoroly acquaintod vith all tho conditions and roquiromonts for tho propor administration of said Act and rith tact and abiljty to noet aid discuss all phascs of its administration vith tho dologatos tithur singly or asscinblod.

Gontlunon, I movo tho adoption of this rosolution.

VOICE: I sccond the rotion.

MR. MCFARLAN: Thon I will put tho motior. ill who favor tho motion will mako it marifost by a standing voto. Gontlonon, it passod.

\section{(Applauso.)}

IIR. WALTERS: It wos noro than kind of you, and wo approciato ito

MR. CARPEITER: If thoro is no furthor businoss, I vili say that I havo thought about this nocting for sovontoon months. It is quito a bit bottcr than I over thought it would be.

I thank you, and tho nocting is adjournod.

(Mdjourmont at 5:45 PM, Janunry 14, 1936.) 



\section{FIRST DAY - Morning Session:}

Address of Welcome by Governor Henry H. Blood of Utah.................. I Address by Pirst Ass't Secretary of Interior $T$. A. Waltors.............. A- 2

(Inoluding messages from the Prosident of the United States

and the Socretary of tho Interior.)

Announconent of Order of Businoss by Director F. R. Carpentor..........

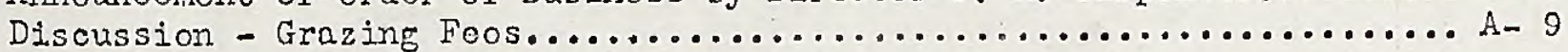

\section{FIRST DAY - Afternoon Sossion}

Address by Assistant Secretary Oscar Chaprian...................A-19 Groeting from Senator Elbort D. Thonas of Utal: (Road by Mr. Carpontor).. A-20 Message from Congressman Edrard T. Tnylor (Rond by Mr. Carponter.)..... A-20 DISCUSSION:

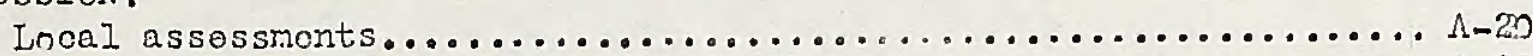

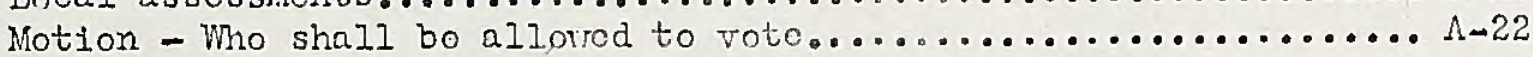
Policios:

\begin{tabular}{|c|c|}
\hline. & $\begin{array}{l}\text { Chango in ordor of proferential closses for license } \\
\text { Motion. } \ldots \ldots \ldots \ldots \ldots \ldots \ldots \ldots \ldots \ldots \ldots \ldots \ldots \ldots \ldots \ldots \ldots \ldots \ldots\end{array}$ \\
\hline 2. & 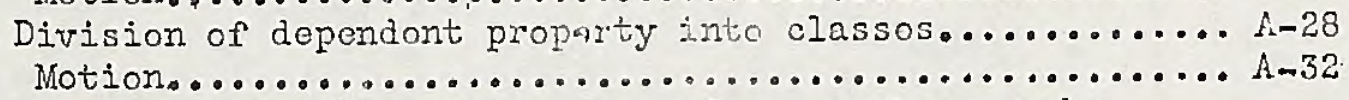 \\
\hline 3. & $\begin{array}{l}\text { thin a class be rade on numbors or by } \\
\text { rostriction of saason of use.... }\end{array}$ \\
\hline $4 a$ & 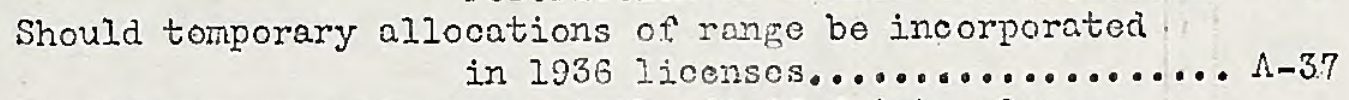 \\
\hline 5. & $\begin{array}{r}\text { Should comonsurato property be divided into classes } \\
\text { and dofinitoly dofinod.......... }\end{array}$ \\
\hline
\end{tabular}

\section{SECOND DiY - Morning SOssion}

Talk by Mr. Julian Torritt, Assistant Diroctor of Grazing............ B- I Resnmendations of Stato Comrittoos, folloring caucus:

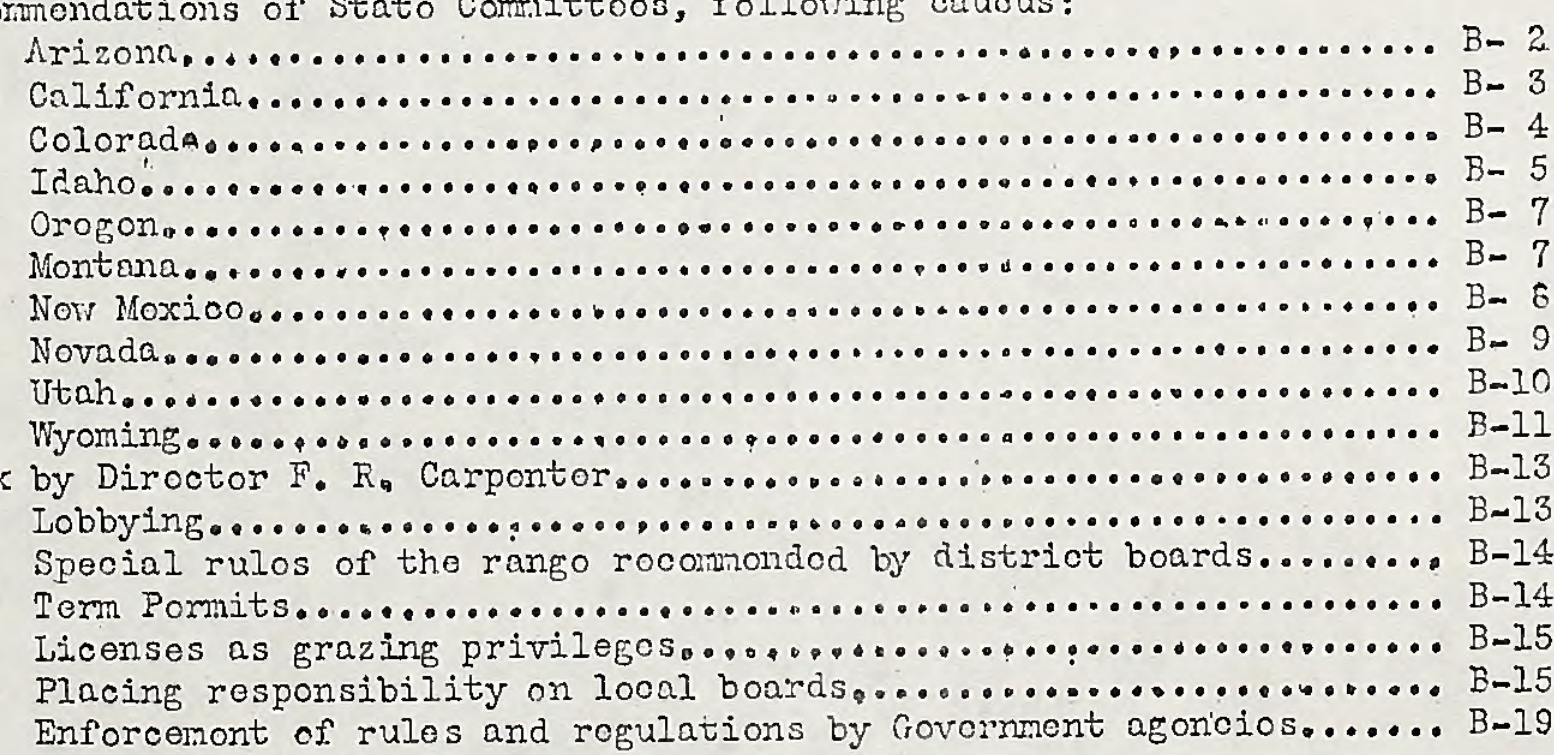

Talogram from Socrotary of Intorior regarding Assessmonts........... B-2A

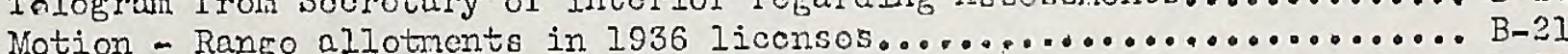
Motion - Division of dependont property into classos.............. B 23 Motion and Disoussion - Defining comensurato property............. B-23 Motion (rodraft) and Discussion - Rango allotmonts in 1936 liconsos.... B-26 lotion (rodraft) and Discussion - Division of Depondont Property

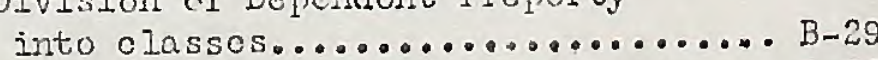

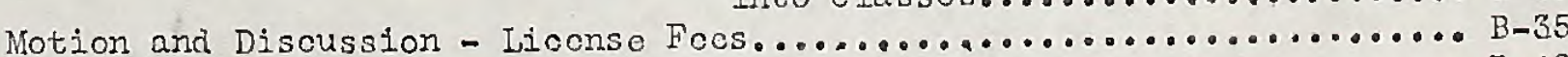

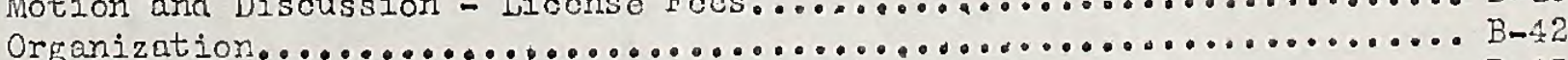

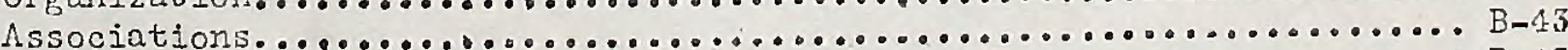

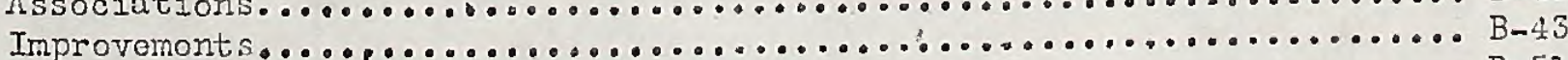

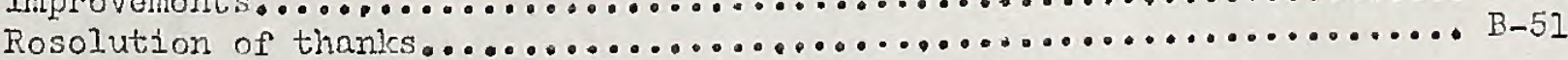




$$
\begin{aligned}
& \text { SECOND ANHUAL } \\
& \text { Distrue ADVSORS COMERENE } \\
& \text { DIVISION OF GRALING } \\
& \text { F.R. CARPENTE, DIRECTOR. } \\
& \text { SALT LAKE CITY, UTAH. } \\
& \text { DECEMEES } \%, 10,11,9930 .
\end{aligned}
$$




\section{DISTRICT ADVISORS: COIVENTION}

Salt Lake City, Utah

December 9, 10 and 11,1936

\section{FIRST DAY}

Morning Session

(Meeting called to order at 9:15 a.m., December 9, 1936, in the Lafayette Baliroom, Hote. Utah, Salt Lake City, Utah).

MR. F. R. CARPEITER, DIRECTOR OF GRAZING: You will recall last year, Gentlemen, we were given a very hearty welcome by Governor Henry H. Blood of Utah. This year, Governor Blood is unable to attend, but we are honored to have with us in his stead, the Secretary of State, the Honorable M. H.l Welling, of Utah. Mr. Welling. (Applause)

THE HONORABLE M. H. WELIING, UTAY SECRETARY OF STATE: Mr. Carpenter, Ladies and Gentlemen, I have the great honor to welcome you to the second conference of Grazing officials charged with the responsibility of administering the national Taylor Grazing Act.

To those of us who have watched the unfolding of this program, this is an impressive and an important hour. The program you are considering was first proposed to the Congress nine years ago by my friend, the Honorable Don $B$. Colton, a representative of tho State of Utah.

From that day to this we have had a large proprietary interost in the control and betterment of the public domain. For years progress was slow, difficulties at times secmed insurmountable. It was no easy matter for twenty or thirty men in Congress to command the attention nd respect of their five hundred associates and colleagues.

Success came with the passage of the Taylor Grazing Act and the setting up of the organization which you gontlemen administer today.

Utah includes more public lands administered under this Act than any State represonted hore, or any state in the Amorican union. In similar proportion, we are grazing morc sheep and more cattle than our noighboring states.

I sincercly tmust that the cooperation you are recciving from the district boards in this state is helpful to the general program. When it is renlizcd that three-fourths of the area of this entire state of Utah is included in the lands which you administcr, it must be obvious that we in Utah are vitally concorned vith the policies which you adopt.

In recognition of these substantial interests, $y$ ou officials of the Department of the Interior at Wnshington, and represontntives of tho restern publiclands states have done us the honor of holding; both of your conferencos in this city. May I rasnectfully invite you to make Salt Lake City and our Statc the permanent headquarters for the administration of this great lav. Wo would like to have you feel that Salt Lako City is the Copjtol of this grent atpire of the public domain. I an sure our peobie will brine to your delibazaticns a spirit of helpful cooperation and support. This stitte cannot prosper excopt through a proper utilization of our range and grazing lands.

of first importance, it seems to mo, is the relationship of the Government to the men who, for years past, have utilizod the public domain as a means of livelihood for themselves and tho fostering of a great national industry. 
These interests are manifested here by hundreds of stock masters not officially connected with the administration of the Trylor Act, yet vitally concerned with its provisions. Their-lives and fortuncs are involved.

of almost oqual importance are the public-lands states themsolves bocause each statc has large arcas of state holding lands intermingled with the public domain. The segregation of these state holding lnnds for state use, as originally intended by the Congress is, I am sure, one of the major probjems of the future.

It is a happy circumstance that as American citizens, enjoying a background of one hundred and fifty (150) years of frec Government ve come to this conference table knoving that all of these intcrests can be settled with substantial justice to the individual, the state and the notion.

In conclusion, may I extend to you porsinally, Mr. Secretary Walters, my congratulations upon being sent here to represent the secretary of the Interior, $\mathrm{Mr}$. Ickcs. Also to you, Mr. Carpenter, me feel l.nrgely indebted for the enlightened policy under which the Taylor Grazires Act has been initiated. This vast empire, Gentlemen, is your homo, and we ore fortunnte to have in Washington men who have grown up on the public domain and undorstand and apprecilate its many problems. (Applause)

MR. CARPENTER: Thank you, Mr. Helling. Our friend, Julinn Terrett, Assistant Dircctor of Grazing, has como out from Fashington today and he is oringing us a message from Secretar. Ickes ma he is also going to make a few remarks on one phase of the lan. Mr. Terrett.

\section{MR. JUIAN TERRETT, ASSISTANT DIRECTOR OF C.PSTING: Gentlemen:}

"To the Second Annual Conferenco of District Advisors of the Division of Grazing:

"I regrct that pressure of official busincss and unforcseen complications in my schedule make it impossible for me to carry out miginal plan to attend your conforence in Salt Iake City. After, the plensant and mutually profitablo conferences with your Advisory Board Chairmen in Washingt on last summer, I had looked forward to another personal meeting with you because I found our conference had paved the way for a better understanding of problems confronting us in the administration of the Taylor Act.

"With two ycars of administration of the Act behind us, I remain convinced that tho Taylor Act is a milestone in land legislation and onc of the most beneficial and progressive lavs proposed and passed during this Administration. I have had ample cause to feel that my origimal confidence in the $3 i l l$ vas well placed.

"I believe that you realize clearly to whot extent the judicious administration of this Act dopends upon the cooperation of the western stockmen. I arait with interest the action taken by your Conference because I feel. that your recommondations will pe of grent assistance to us during the coning year. We have made substantiul progress but re should not be too completely satisfied.

"We still have beforo us many knotty problems. I feel confident that you will give these mattors jour accustomed considoration and extend to the Department your carefully weighed counsel.

Flarold I. Ickes

Secretary of the Interior"

I now want to draw to your attention some littlo known aspects of tho Taylor Grazing Act.

The Tarlor Grazing Act has been so videly discussed in the vest as a practical measure for livestock men in setting up grazing districts and as a means of leasing and selling tho remaining public lands which arc so situated as not to bc properly included within a grazing district, that some of those larger and more far-reaching features have becn commented on very little and, in fact, 
are just now beginning to be observed by thoso who are in close touch with the 12.27 .

Tho features to which I refer are those made possiblo by the Iangunge in Seetions 2, 9 and 12 of the Aet, whereb: cooperative agreements are authorizod botwecn the Secretary of tho Interior and locnl associations of stockmen, state land officials, official state agoneies, fedoril agencies and departments, with almost no limitation in order to accomplish the purposes of tho Act, which are stated in its proamble as follors: (Quotd)

"To stop injury to the public grazing lands by preventing over mrazins and soil deteriozation, to provido for thoir orderly use, improvcinent, and development, to stabilize the livestock industry depondent upon the public range, and for other purposes." (Unquote)

In the first meetings, whero this Act vias publicly discusscd in tho ten (10) vestern states, many state and local asencies which had never heretofore actively cooperated with the Federal Government, vere called into conference. State boards of land comissioncrs, state fish and come commissiorers, railroad land commissiorers and local associntions of stockmen, all of whom heretofore had been individually pursuing tineir va* as regards the handling of land in direct relationship with the public domain, 7ere invitcd non to participate in the benefits which misht aceme from coonerative asreement with the Secretary of the Intcrior in carring out the purposes of the statute.

There have now been made and signed, a number of such cooperative agreements of far-reaching effect. The first of these was the now famous Ne: Hexico plan for the protection of rild life within grazing distriet. Another coonerative agreement is that between tine Secretary of the Irterior and the Oregon State agricultural College, whereby the Rango Explerinent Station at Squaw Butté, Oregon, built and equipped by the Division of Grazing, has been stocked and is being operated by the college for the doturnination of proper range practices.

More recently there was signed a far-renohin cooperative contract betwecn the Secretary of the Interior and the Southern Pneifie In: Company, which will allow the groupins and correlation of some four and ono-nalf million acres of checkerboard land in the states of Nevada, Idaho and Utah, and the publie lands interspersed therein.

At the present time there is under consideration a cooperative agreement betmeen the State Land Board of the state of Utah and the Secretary of the Interior, which will accomplish moli the saile purpose.

Then we hare the cooperative agreenents vith looal associntions of stockmon of which in $\mathrm{m}$ o:n state of Montann, I am proud to sar, there are now thirteen (13) in aetive operation, wherbby the publie lands are handled in connection with the state and private lands witn which they are intcrspersed by local cooperative associations of stocimen.

These cooperative agreenents permit a ecordinated use of the Federal, state, tax defaut and railroad lands, which are so intermingled that the proper use of one cannot be made without usc of the other.

Cocperntive agreements have been entered into with the Soil Conservation Service for the betterment of the range and to prevent erosion, with the Biological Survey for the protection of gnme animals and birds, and for the extermination of rodents and prodatory animels, and with the Rescttlement Administration for the joint control of resettlement lands lying within grazing districts.

As pointed out in the beginning, the field for cooperntion is almost without' limit. The Division of Grazing stands ready to work for the consummation of any cooperative agreement contemplated in the lav and to cooperate for the public good, not only with the private ard state ageneins, but with ail Foderal agencies and departments. I thank you. 
MR. CARPENTER: Gentlomen, I feel that we hardiy need any introduction for the next epeaker, who has the principal address of the day. He is our good restorn friend, the Honorable First Assistant'Secretary of the Interior, Mr. Talters.

THE HONORABLE THEODORE A. WAITERS, FIRST ASSISTANT SECRETARY OF THE INTERIOR: Dolegates to tho Convention, Ladies and Gentlomen, It is vith some regret on my part this morning that I am not privilesed to speak to you more freely than I want and more direct, however, under the circumstanices, it is advisable that we relate to some extent, the accomplishments and purposcs of the Act and draw attention to the provisions and objectives of the Tarlor Grazing Act's accomplishments and results.

Less than a year ago, a month and three days less to be exact, we met together in this city on an historic occasion - the first conference of Erazing districts dolegates from our ten restern states. It is significant that that first conference surpassed the most hopeful expoctations in settins new and high standards of cooperation between the livostock men using the public range and the Federal Government. It is my sincere hope, yea, it is based on a sound belief that this present conference vill bring forth greater benefits for all those concerned with the public grazing lands than did the first onc. In this hope and belief and in the recollcction of the ver, pleasant and rorthrhile association with you in the past, I am naturally hanpy to be with rou again at this second milestone in our brond conservation highway.

The Tavlor Grazing Act is a part of the land history of our nation and bids fair to be one of the most important of all of our land laws.

Coming as it did after every possible method of settlement and development by private persons had been full" explored and used and all of the public lands which werc capable of producine nnythine to pay for local taxation had bcen patented and put on the tax solls, it dealt mith a type of landinever heretofore the subject of legislation.

The lands in crazins districts arc the left-orer lands after three generations of settlement - they are the dryest and pporest producing lands in the United States. In and of themselves they have almost no value, in connection with the private lands and water that largely control their use, they are indispensable.

From this fact came the now famous preference clauses of section 3 of the act wheroby the srazing privileges of the public lands in frazing districts arc to be used first for the proper usc of the private lands and water that are naturally correlated with them. Such a land-use statute as this presupposed that the proper use of the private lande and water was cither a knom fact or one that could be determined. As a mattcr of fact this restern country has been so hastily settled that even fow of the inhabitants knon exactly what the proper use of their land is. Lands mich for many years were used to raise hay became suddenly more viluablc for beet or lettucc raising. Pasture lands never ploved before became more profitable in cultivation whon wheat goes above ono dollar a bushel. For the past thirty years we have seen our private lands change in their propcr use again and ajain.

I recently looked at the first public survey map ever made of the Unitcd States. It is a part of the files in the General Land Officc and is dated 1866. That map was proparod within the menory of many men now living, and yet it did not show even so much as one govcrnment survcy post in the States of Idaho, Montana and Wyoming, and only a base meridian line in Utah wherc the Mormon sottlemonts were and in Colorado, Nevada and Ner Mexico just a feri surveyed tomships where tho gold minine activitics verc greatcst. This is cited just to show you one of the principal reasons why wo not know the proper use of the private lands and water of the public range areas of the. eleven westcrn Statee.

With this far reaching and statesmanlike objective of working out a proper land pattern for the proper relationship of private and public lands in the West, it was only natural that the Taylor Act should not be put into immediate operation eo far as its land-use objective was concerned until that could be ascertained. 
A method of temporary grazing licenses was found to be authorized in the broad provisions of seetion 2 of the act to take care of the existing livestock industry until the proper use of the private lands and water was worked out. This is only a step in the process of gathorine the data upon whieh to base the distribution of grazine permits. You are assistine us, and in faet doing the major part of the work of inventorying the lands, water, and livestoek now being used in eonneetion with the publie domain,

We are now for the first time asscssing all of our range lands, private and publie, in an endeavor to put then to their proper use, which means their right relationship. There is something almost avenone about participating in a work of this kind whieh stretches so far into the future vith its results. This conferenee and probably many more will be neeessary to eomplete the program, and only the inhabitants of this sreat rcgion, we call our home, years henee will be able to appraisc the quality of our work and whether it was done in a vay worthy of the traditions of the pioneers who first subdued the savage ard mildlife of this aren and who left to us this task of saying what is the proper use of the private lands and water and their rifitful relationship to those lcft-over lands whieh constitute the great "national ranges" of this eountry of ours.

We have made progress in the eleven months ensuin: since our first meeting, dospite the fitet that both our problens and the areas so be under the juris diction of the Grazing Division of the Departmers ef the Intcrior have been inereased. As rou recall, the Taylor Grazing sict was amended June 26, 1936, and the permissible area of vaeant, unapproprinted. and unroserved public lands which right be brousht into erazinf districts was increascd to $142,000,000$ of aeres. Even though we of the Fest are accustomed to dealinf in vaster acreages than are our more casternly neigibors, this is still an enormous territory for us to administer. If these millions of acres vere groujed together an idea of their area can be obtained by drnvines a line on the southern boundary of Marrland and Ponnsylvenin, nround the western boundary of ohio and following the shore line of the Grent Lakes and the Ganadian boundaries back to the Atlantic Oeean. All the lands included retreen this line and the Ocean -. eomprising the states of Maine, Ner Hampshire, Vermont, Massaehusetts; Connectieut, Rhode Island, New York, Nein Jerser, Delasare, Pennsylvania, Maryland and Ohio, would equaj onli the $142,000,000$ acres. This Eives us some idea of the vastness of the rcgion whieh is now, for the first time, being brought into operation and its proper. relation with the land which has been used and useful in the past in procting the roat livestoek industry of the northwest.

As of November 1936, fort\%-eicht crainf districts have been established, totaline a Eross arca of $253,012,888$ acres of which $110,000,000$ everes (in round numbers are vacant, unreserved and unappropriated public lands. of these forty-eight (48) orrzing districts thirty-seven (37) are now under active administration and progress is being made in bringing under administration the eleven (II) distriets which have been recently established. Advisory boards have becn elceted in all of the eleven hew districts and it is anticipated that the administrative orsanization in each of these distriets will be fully completed in time to issue crazine licenses for the season of 1937. An additional distriet in Oreson is ir the process of being established and it is probablc that in the near future still another district will be established in Colorado.

There is a Ereat deal more to the administration of the public Erazing lands than appears on the surface. To mr mind, one of the most outstarding eontributions made by the Tarlor Grazing Act and its rise administration under the Interior Department is that throu the cooperation of the livestoek men themselves and the establishment of distriet advisory boards, a ner eontribution to the American way of life has been made, n new contribution of Fedoral Governmont administration. In handling a vast and eomplex situation, an or sanization has been created on Demoeratic principles in which those most vitally interested in the administration of the puilie resources have had and are having a fundamental part. Through the coopcration of the district advisory boards both the appearanee and the actuality of absentee landlordism on the part of the Federal Government has been avolded. 
You vill roenll thet following the meeting of last January, the information brought out throush our diseussions was used as the basis in formulnting the 1936 miles and regulations governine the issuanee of grazing licenses. In July of 1936 a conference of chairmen of the district advisory bonrds was called at Jinshington by the Secretary of the Interior, in order that their experience and recommendations might be brought to bear on the problems involved in brin ins in of an additional 62,000,000 aeres under the grazing administration. The chairmen of the thirty-seven district boards then established were asked for a frank oxpression as to the progress which had been made and for their recominendations on policy. In passing I may add, and it is with pride tho I do so, that no ono of tho chairmen at that meotine had any serious objeetion to make to the administrative organization thus far giren or to the organization or the setup as to the orgonization which vas conduetine the affairs of these grazins districts. Before ther ndjourned. they passed unanimously a resolution eomplimentins the Secretamy upon his administration and emphasizing their endorsement and ploasure in kis recognition of the principle of locnl autonomy and his alppointment of men to ker positions in the Division who have first hand lenowlodge of the livestock industry and with privately omed property used in connection with the public domain as well as with the economic fentures and problems involved.

And to those who attended, I have a picture talcen in front of the building, framod by tho isological Surver, and it is now haneine in my office, with the name of each in?'ividual, aptly protrayed at the bottom of the pieture.

I feel that those individuals possed resolutions which were more than the ordinary run of resolutions passed bi similar meotincs. Ther did not hesitate to express their frnnk expression at any time and any place, and for that reason, the resolutions, I folt, meant more than as I have said, the ordinary mine-run of resolutions.

During the last tro years we have provod conelusivol that home mule on tho rance and deeentralizntion of authorit: are not only practienble and worknble but thrt such a sistem, althourh new in renlines betreen the Government and those usinc our neturni resourees, is one of the best vot ovolved. This is due in no small measure to the thou hiful and nile mork of the distriet ndvisory boards.

I am inelinod this morninis to note from a report made from our energetic, industrious and thoushtful Director of Grazine, Mr. Carpenter, wherein he sars: (quoted)

"A prime foree in the administration of the Taylor Grazine: Act is the district ndvisory boards, ennsistins of elected represertatives and stoekmon in each distriet. Thero are 533 ropresentativa ard rible steolmen in an advisory eapaeit, serving on these boards.

"The advisory boards have been invaluable to the Division. Only those who have personal knowleare of the facts hnve any coneeption of the nnount of time and labor thet menbers hare devoted to the rork of recomendinc; ndjustments and alloeations of rance nrivileges in their respective districts and in nooptin fair and reasonate rules under which those alloeations eould bo made. A orent amount of work has been done by various board members, prrtieularly tile chairmon, for which they ean never be compensated in dollars and cents. These men have shown overy evicienee of fairness in their recommendations, and many mombors hrie fousht for the adoption of eertain prineiples even thou h the result mould be detrimentnl to their om personal interests. Desnite the fret that the vostern range men often have been aceused of using tho rance in ruthless manner without regard to eonservation principles the bonrds have, in many instances, of their ovm volition recommended either substantinl euts in the enrr-in: capneity of their districts or a shortening of the season of use." End of quotition. 
With such an orgnization we have male real pregress. There are tiose who arc rot informed and who have said me have done nothing, and there are others who for rensors of their own maintain that ve should have accomplished imoossibil1ties overnicht, solvod every problem, nnd created a perfect oriasiantion rund tor.w be functioning as though me had been in existenee for a docado. Theso are but thoushtless expressions. You who are aequninted with the work at hand know that re have more than ono objective and knot that vo are reachinf toward those objecivives with ressonable sneed and vithout the necessity of paring tho penalty for ureconomic nnd tco hasty profress.

is a part of a prouress report I shall deal briefly with the situations involwinf: erazirf lonses unier Section 15, exchanges under Section 8 and the public sale of isolatid tracts under Scction 14 of the Aot. Ir order: to expedite the issuance of grozins ] sases undor the authority contained in Section 15, on October 22, the Socretary eliminated 011 red tope and directed the Commissioner of tho General Land Offices to issue instructions requirins the resisters of tho land Office to take action immeäiately on all pendirs applicaticns. It vill be remembered that while Coneress had undor consicieration the question of inereasin: the acrcake of the purlic lnads to he inojuded in grozing districts from $80,000,000$ acres to $142,010,000$ acres, it rns imossible for the cenoral Iand Office to take netion upon rendin $\ddot{E}$ appitantions becniso of the provision of the lam that grazing leases mor bo issmed only for such lands rs rore so silunted as not to justify their inclusion in crazing cistricts. Inmeatately after tho issuance of these instructions, cortairod in Circular No, 1112, a number of experienced emplorees foon the Goneral Li... Office ficre intailed to severnl of the United Siatos District Lnde offices. To elirinate the delay involved in the submission of formal reports by the Division of Investigations in ench individual case as had bcen required theretofore, spocin nents were dethiled to the District Lond Oifices who more fnililin with tio lands ir. the vorious districts so that the; litit act in an advisory enpacity, especinliy in the divisjon of the range between conflictire applicntiuns. Lenses issued under the irstructlcns of October 22 are for nne ron onl $\%$. All action taken, however, with reference to these npplicrtions is subeot to conenl.

As rou aro amare, the rental fees char on on blese lenses is in harmony with the fees vithin the srazinë districts. The were the fees heretofore establishec..

Thile the roulations require mulicntion for each abpliontion for 760 acres or loss in order to meet the ninot:--.ing prefomnce ascorded omers of adjncent or cornering lands the worle hns beun simlified $3:$ expedited ly tre recent authorization of blnnket purlicntions at Goverment expcnse by colinties in those states where ny substantial numoer faphlications have been received.

I" view of tho prorisions of tre Act that orily those lands so situated as not to justif their inclusion in brazin districts my be leased, it has been necessary to reject ali applicntions within cxisting or jropored crazina districts. Each applicant is advised, however, that such notion is without prefuaice to his right of appeal to the Division of Grazing for a grazinglioonse to graze rithin erazinj distriets when such are established.

I would Iike to mako it clear, horever, thot in the event an application is not ararded all of the lands applied for he rill be full-r advised as to tre reasons therofor and that tho Register's netion is surject to ti. right of appoal. Whether or not an appenl is filed his rists as to an jands applied for but not

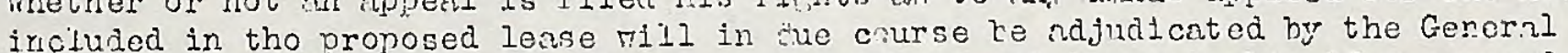
land Office and such lands incluoed in a sumplemental lease to him if warrinted.

In order to protect tho public lands included in these rrazinj lenses provisior. is malo whereky the Government reserves tho right to have its antinorized reprisentatives enter the leased premises for the purpose of inspection and the leases thomsulves are subject to canceljation for persistent over razin; or the use of the lards in any other muner which couses soil erosion or for any purpose dotrimontal to tho lnnds or the livestock industrir. 
Accortine to reports receired as of lovember 28 of this yenr, 2230 applications for grain lenses under scction 15 have been rejected, 757 lcases have been scrt to npplicants for execution, 373 lchsan inve been réturned duly executed, 398 lcases arait the expiration of the publication poriod and 684 have yet to be considered. You vill note, that is as of lioveriker 28th. Byr this time, the rumbers which have been cxccuted or sct out for crecution, havo been lareely alinented, since the Land Office is now in tre procoss of executing these lenses and cxpediting action relative ta them.

Continuine; our statisticnl trend for the noment, it pill interest you to know that 423 applications for exchrnc of state-orred lands for public lands under authority of Section 8 have heen filec hy the States of. Arizona, Colorado, Ner" Mcxico, Montana, Utah and hromine. Aproximituly two and one-half million acres are involved in these applicaticns. Phe aromic selcciion list includos about six thousund acres, although some embruce as much as twenty to fifty thousand acres.

Somo of the applications for exchange have been rejected becalse of advorse reports on the cround that their anyoval would interfere with tho administration of srazine districts. A considcrable number of applications nuve bcen rejccted for the reason that the selected lands rere withdravn or otherwise not available.

Dclavs in the consumation of State exchnfyes have boon cue to the fact that a l.n.e number of the amlications were filed prior to the issunnce of the reculntions, wich necessitated the filine of supplemental applications. Also, in a larse number of cases unsurvered school sections nerc offered as basis for exchanec, which base mas not valid prior to the nmendatory act of June 26, 1936. The amended fet provides that where the solected lnnds are within a orazing district the basc lands must be within the same grazinf district. It has thus keen nccessary to require amencment of mny of the pending applications by substitution of valid baso.

Some of the States have takon adventace of the provision in the amendatory agt which permits strte exchanges on the bists of equal acreng;e, as well as equinl volues. The procedure under the equnl nren provision makes unnecessary a field investigation for the purpose of determining values, and where a State elects to receive title to the selectel lancs, with a reservation of all minerals to the United States, no ficld examination is reccssar: to establish the mineral or non-mineral characteristic of the land. so sclected. Under a recent rulins of the Denartmont it has ceen held that Stete-owned lands within reservations or withdrawals mo be offered as a basis for exchange under the Grazing Act. This considerably widens the scope of exchances permissiblc.

At the request of the Stato Board of Iand Cumiasioners of liontana, the Department has recently authorizod the detailini of a romesentative from the Division of Grazine and from the Division of Investilations to cooperate with the representatios of the Stato in makinc tentative juns for exchane of State lands. Sinilar cooperntion will be extended to other states upon the request of such states as arc interested.

Applications for the exchange of privatel-momed lnnds have been less active, but 37 have, been recoived, four of which have been rejected and the remaindcr are awaitin reports from the field. Onli one aplication has as yet been reccived for the exchnnge of railrond lands as such. This is due possibly. to the fact that some, at lcast, of the railrond cmpantes have frozen security under bond issues.

There has been but little interest sc far shown jir Section 14 of tho Act, as indicated by applications receiver. Up to the present 641 applicatiors have been received, patents have been issued in 15, snles authorized in 5 and denied in 457 cases.

The Department of the Interior and the Division of Grazine are making evcry effort to overcome the situation presented bi the checkerbonrdinf or stassering of the owncrship of certain lands and its attendant administrative difficulties. I an convinced that this particular problem, trourlesome as it is, is canable 
of solution and if we continuc such progress as we hnve already mate we will arrive at a sntisfactor conclusion. As ar eximple of one approncin to this problen I mis cite the coperetive arrecments entcred into bit the secretary of the Intcrior, beginning lforch 17, 1936, with razing associations in the State of Nontana, where the public lands constitute only ipproximntely tment; + five percont of the area and are interminiled with statc, countr, tax default, railroad and othor privately omed lands. Whese mrocments are adaptable for use in any other state where a similar situntion may bo found to cxist.

Realizing that permits could not be issued until a comrehensive and rcliable ranire surver is made, a survey rilich rill sho:; not only the carrying caraoity of the public domain rances, but also the on.crsin of the privetc dependert properties and tho number of stock for mich they aro commensurate, the Divislon of Grazino has issuca temornr licenses to those engared in the livestock business havin $n_{\ddot{E}}$ dependont comensurnto proporty vith priority of use. To date approximately 17,083 licensos have boen is suen which have a class 1 rating, covoring a total of $7,553,476$ livestock, composed of $1,644,434$ hend of cattlc, 95,700 hend of horses, $5,653,395$ head of sheep and $1.58,947$ head of goats. These licenscs are temporary, as you lenorr, in character. In the main they form a recomition that the dependent commensurate nroporties upon which they are based are cntitled to Errzing privileses, althouch the exact extent of this crazire privileze has rot ret been definitely ard finaliw dotermined. This cannot te done until the rance surver procram is completed. However, the range survey promram is well under may. Eecent reports show that a total of 640 tomnships have tcen surverod ir the ten restorr. States, and, 6, 162 dependent property roports have been made out of the entire number of dependent property roports amountine to 14,063 .

In the 37 erazine districts where there is active administration, a vast amount of preliminary work has been accomlished. In addition to ranse survey programs, just mentioned, a tremendous amount of rnneso improvement has been inlanned, and a considerable amount has been coimicted. This mork; as you are aware, has been done largels throuch the $\mathrm{C}, \mathrm{C}$. C. camps under tho control of the Division of Grazing.

In addition to this, jou are rell acquninted with the provision of the lav

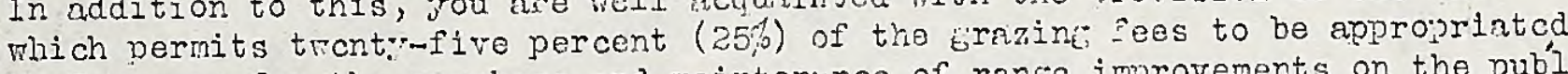
by Consress for the purchasc and maintenircc of rance improvements on the pubilic domain from which the fees have bcen dcrived. These improvenents, as wel.1, ngi those made by tho C. C. C. camps, have been madc and locnted only aftcr amproral and recommentation of the local advisory boards havine jurisdiction in tho areas in which the improvenents vere to be made, thus givirg assurance thet they rould be prnctical in nature, properly locnted, and so constructed as to give a maximum of use, protection, and benefit to the range.

It vill undoubtedir be of interest to know that in connection with the range improvement mor!s of the C. C. C. camps under the Division of Grazing that estimntes have been marle showins that we rould he able to use properly and efficiently, two hundrod of these cams, ench with a personnel of two hundred individuals, which pould be useful in carmine to a final consummation, some of the most needed range improvements.

Some of us are interested in the conservatior of vildlife on our public ranges. Many of you already know of the New Vicxicn plan, as mentioned by Mr. Torrett, and undoubtedly many of you by this time are faliliar with the wildife protection program adonted by the advisory boards in the state of Oregon. A dotailed account of the Oregon Jlan would not be annonriate at this timo, however, it contains a recoenition of the rights of and the need for game protoction on the range. It calls upon the State Gare Commission, Forest Sorvice, Biological Surver and all other interested parties to cooperate with the Divisjon of Grazins for the conservation of our vilulife. This plan has mct rith ceneral approval, and it is now, being submitted to the advisory boirds in all of tho districts throu hout the ten pestern statns rith the oxcortion of lew Woxico. Its erthusiastic reccption i's proof positive that the livestock men as a whole are not only wildlife conservationists $a . t$ onrt but believo in the conservation and dovcloment of all of those naturnl resources which contributo to making the rest economicnlly, socially and industrially a bettor place in which to live. More attractive, if jou plense, to the human family as a vhole. 
In conclusion, let me assure you this mornins that your deliberations durine: this confercnce will be closely followed by Sccretary Ickes, who has requestcd me to extend to you his Grectings, ard that the recommondations you make will receive the careful consideration of the Department of the Interior, in connection with the essential and proper administration of the range during tho coming year. I thank you. (Applause)

MR. CARPEITSR: Gentlemen, I was taught to believe that in tho taking of mach counsel thore was strength. If that is so, there is goine to be an anful lot of strensth given to the administration of the Taylor Act by such an assemblase as this, because I sce before us today the men who are the most vitally concerned with the proper handline; of this lat in the ten western states,'not only in number, but also in the character of counsel we will iet, for I recollect very well the words of a very wise teacher under whom I sat. He said, there are two kinds of counsel you could get in this world ... the counsel of men who made theirs and were tryine to keep it, who vere occupine the lobbies of hotels and the plush seats of retired men's clubs. And the other kind of counsel icomos from men who were on the make, trying to mako their living and were in the heat of the conflict.

As I look about in this assemblage, I realize it is this latter time of counsel that we vill got hero today, and oo. I feel more than evcr, it is the kind to be relied upon.

We are going to follow this order of business in this confercnce. There will be a general discussion here today. Tomorrow morning at 9:00 a.m., you will meet by states, and you rill discuss the, state attitude on these topies mentioned in the program, and there you will clect two remresentatives of a najor comittee, which will meet in the afternoon to discuss each of those six great topics. The major committoes will meet in the afternoon and complete thoir drafts by nicht, and on Friday they will meet here again in the cereral dssembly. The results of the six major committees will be dehated, ndoptod or modified and that will complete the second annual conference of the District Advisors.

For this morning session, before me open up the topic for discussion, the'first one is licenses, followed by permits, I want to mako $a$ brief statement in order that you may orient yourselves and approach this in a way that will get to the pith of the matter as soon as possible. The comonest remark I hear, as I travel about from state to state and ask what, in their opinion, the Tavlor Act has done for them, is to say it hasn't done anythinf but slap a fee on us. To look about on the range and to observe this act, without some consideration and study, that might bo accepted. However, beforc this body of men, who are the co-laborers in this field with those of us who are in the Federal Government, before that result is accepted I vant to just briofly touch on one or two things about which you may not have thought herotofore.

The Taylor Act has preserved the status quo of the time of the organization of the district, that is, -- no new operators have been allowed to como on and start in grazing on the public domin. It is required that the old operators only go until such time as we can determine by thorough and proper consideration of the land. That, in and of itself, has been a proper protection to the public domain, as mell as to yourselvos. I notice in the papers, and it is true, that there has been a cut of some 800,000 head of livestock. I do not wish for a minute for you to think, and we do not think, that the end and oyjective of this act is to cut numbers of livestock. The end and objoct of ihis act is to incrense numbers of livestock.

However, we stepped into a progran wich was slippins in a direction that we were not able immediately to stop. I heard some figures from the Socretary of the Utah Nool. Growers Association that astonished me. He had the figures of the number of sheep in Utah since 1920, and, gentlemen, they have been slippins since 1920 at the rate of a million or less since 1924. That procoss was started before the Taylor Act was enacted and you cannot step into a decreasing ranse, as the Taylor Act did, and arrest $1 t$ in a minutc, and so it vill be necossary for somo timo to make this adjustment and there mat have to be a considerable lessening of the livestock numbers because, as we knot, unloss this range 
reaches starility and has protection, there is no hope for any of us and that means not only our livestock, but our private properties that are dependent thereon. Is not think that the Division of Grazing feels its existence will be justifiod by cuts in the numbers of livestock. The Division of Grazine feels that its ultimate justification is by increasing the numbers in livestock.

We rcalize that livestock is the underlying hasis of the agricultural fytem. We rcalize that the total cash receipts foom livestock and its products in the United States in the year 1935 exceoded tie/trital recelpts of all aeficiltural products combined by over, suno $\$ 700,000,000$. That is to sey, thirticen saiectcd livestock items and their products excceded the reventy-elsint other prodrcis, which are cotton and tobacco ard whest end coin, and nil the rest of then, and not only that, but the livestock consimed tha by preducts of tho principul other industries of the courtily - - the reet factories, the mistrefe from ine erraping fields, the stubhle and the straw, and in a thcisand other ways, livostock is the one great supporting industry of tiis ontire country. And for that reason as the livestock industry prespers, sn prospers the other industries of noriculture, of which it buys most of its products and buys directly and indirectly.

How inany industries rould be here if tho products of tho existing livostock industry and mines failod us? None, and so ultimately wo hope to support more cattle and horses, sheep and goats thrn ever before.

But when we step into something that hrs beon going down hill as this purlic domain has, it takes some little wirile to ket the matter adjusted and stopped, and that is the roason wo read those rerorts, which are of a complex nature. I am not going to recito hore the by-jrolucts of this act, out I beliovo mo have renched an all-timo high for Government divisions in the matter of cooperation. We have entered into active cooperativo agrecments with associations of stockmen. We have ontercd into active conperntion with great railroads contrnllins a groat ompiro of land. Wo havo negotiated cooperative acreoments with State Land Boards who orm a large part of the priblic domain, particularly in this state.

To have entered into cooperative agreements fer tho handline of vildilfe and for ranse experiment stations, and in addition to those ae have Government cooperativo agreements with the Soil Conservation and Biolngical Survcy, and many other agencies of Government. This action has spread out and now you see foeussod in this meeting the results of the morls.

There arc those who say we have done nothine hut slap a fee on them.

Tho average life of the grazing district in tine rest is scventeon months and twenty-six days. That leaves out the notly orgnilzod districts that nre not organized as yot. Severteen months and twenty-six dnys is the averase life. It is questionable whether or not we havo not exceeded everthine wo noped to do, as it seems to mo the main objective that we hare reachod is that ro have anquired a way of workine together, nnd we hare forover answered the aso old saying that I hoard whon I rent around these stites. Deople usec to tell re that cattlo and sheonmen could not sit dom arionbly in a room and discuss a subjoct togethor. That is a thing of the past.

Those mon in this room have proved it, is a thing of the past. I hare becn in plenty of meetings in my day viere the sheepmnr. sat, $\mathrm{nr}$ one side of the room and the cowboys on the other. But I can't spot which is a shoopman and a corman in this bunch today. I am happy to see that. That is one thing we have nroved.

There is another thing we have proved, and that in stcclen intcrested in the

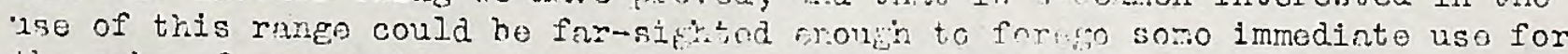
the sako of presorving and rehabilitatine tho pinli: domin. Thore are thoso who said that was impossiblo - to foreco one littl: rlade to grass to let it seed down. They vanted to grah it off and use it ty is rear and nover mind the futuro. Tho wastorn mon have shom that thcy ore ishing townd the futurc.

Thon, lastly, there is another thing that we have donnetrated and that is these new districts that have been sct uf, have romlomonstrated it, in the 
inauration of this system of administrntion, I consistently heard from very substintial operators that the idea of "one man, one vote" rould be very disastricus Ecnerally to the laréfor outflts, that the board rould be dominated by small tro-by-four men, who did not knon just what it was all about. Pimo after time it ras domonstratod not to he so. Tir:e after time it was acmonstrated that tle vestern runcio Iivostocle men vote for the ma, neither bië nor little, but the man in whom thcy had confldence.

In these ner districts set up, I met the sar:e objcctions. "Don't turn us over to tho mercios of these flat-footed iamers" nmi the "flat-footed fariners" voted the best of nny ramgo mon, I am told, in the new sotups that have come in.

So, we have ren.lly demonstrated the sound. principles or which our Govarnment is bason, of one man, ono vote, and the ability of tho neonle to elect reprasentam tives who will represcnt them.properly. Those thin's wo have domonstratod.

Te now have a rorking machine nnd we ha*e a problen beinno us. Tis have mouthed it around Ion: enough in our muths until ve know riat it was about, until now the time has come when we want to sink our tceth into it and laor exactly where we are going. This industry will ncver hit its stride unti]. ric reach a degrce of stabilization, so man will mow about where he is one ycar from nor, and vill know where he is goln to be ten yenrs from now, as rell ns ono month. That is our bif objoctive.

That brinss me dom to the topic in hand, which is the matter of licenses and the matter of permits. The two havo to oc taicon up tocether. I an ecins to sketch out a little nrelininary statencnt and then open tho matter for discussion from the floor. Before I do that I wiII nunounco certain rules that I beliove wiII moke for our best prouross in the discussion.

Do not make anr mistake about the Tarlor Act. Tho Marlor fct was set up as a land stibilization act and incidentaliy, and, of course as a direct result, to stabilize the livestock'inchstm. It was set up to find out the proper relationship of those public and private lnds, and insofir as consistent with that purpose to arrard priorities and protect then anch allow them to use the rance. Now, no rance man could read that law and start in to adninistor it, because nobody in this world knem what the proper relationship of the public and private lands was. That relationship had boen denonstrated bir use. I have found some livestock travelin: a thousand milcs to use a bit of land here with another bit of land. herc. It had bcen established by custor. and it hal boen establishod by cattle, but it had not been established. by proper inyontories of all the properties of the rest. I realize the hopclessness of such situntions.

I ment into this pork on September 12, 1934, and the third day I was in the rork I mroto the Solicitor of the Department and I asked him whether it was possible to set up a preliminery setup to taire care of the oxisti.g industry until the public domein eould bc inventoried and to discover the propor relationship of these lands, whethor the powers of section 2 verc bront on wh to disregard the mandate in section 3 , which saj.d that priorities and range privilcres should be turned in only after the lnnd usnes vere requircd, becnuse if that had to bo done re rould have to wait for thrce or four vears, until we found out what the land vas.

IIc said the powers in section 2 were sulficict that re could sct vp sufficient setup to mako and to consider priprities and rnnge jrivilcges recosnized anc acknowledged and as nobody knew what range privilesos were, and as nobody know how they were to be rccornized and acknowlersed, wc were told to find out and recommend to the Department, ard you have arvised us ?) Ienty.

If you will look on the back of your program you vill find the advice of thirtysoron (37) districts, all the way from half a year to ten jeara. Call it a composite if you like, cnll it a hodso-podse if you like, but it was done by princtical poople in a practical way to take cnre of a situntion, until the day ras here until ve could $0_{0}$ into the working part of the act and also to mike a cusion or shock absorber before the relationshin of that linde ras pronorly norked out. That has been your job and mine for the nast two ycnrs, and that has been worked 
mith lahorious study and appropriation and coneiliation. Our woik in somo eightocn thousund $(13,000)$ specific cases in hundrods of moetines in which you men have stayod lons over union hours and workod, and vinile your nor: may not be perfect, at least you have a machine which picked this thing up within six months after tho onactment of the act, within six months after the districts woro sot up ve have what is an American rorkins machinc.

Last year, you may recall, you mot here and you took the instructions of Mry 1936 and you kieked some of them in the waste paper baskot. and we took five great results back to Washington and ineorpornted tiom in the Fulos of frarch 2 , 1936, and undor those rulos sre have been acting. Thoy are not porfect. Thoy are only a step in our progrno. To, at this time, can appraise those rules and say what is wrong about tho license mothol.

You vill find on the bnck of yoin niogran, nr ectimate prepered $b_{i}$ the man in chase of Railgo Surveys, telling nicut what timo cacis dist:jet with the prosent por'sonnol can havo the data where ny Gurcrnential aconcy caln movo in with any degreo of sanity and try ha say what tro propor relutionshpp of the land is. Ycu $\nabla i l l$ notice that mino of these diatriets aro mir yoars offo

When the distinction vetwoen liconses and fermits aro f. lally understood there vill. be somo who will nover vant to ge's on permits nat some rho will want to get there tomorrow marnin: au $7: 30$.

That is that we rant to do here today, mainly to clarify the difference, and see which way wo are going rid I nil trying to set up some kind of gaidenost with which we can julge"e it.

I recollect a Kexienn who hak an old team of miles, and that Merican nnd those miles used to synchrcnize their movements so you covia not tell whether thewere moving at nll. You vould hnve to get a lons wers off and cet a post or tree betwoen you, and then you could see whieh ray they pero going.

The man on tho range doos not 1 wor which way he is coing, and I have also henrd some mell-informod mon express the foar, that wo rere soint ton fast in this matter, and tiat is another reason for this conieronce, in irder that we may definitely face tho is gues and ino: rilat it is wo nre coing to do We aro

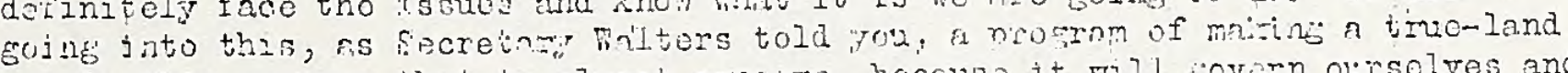
use in this corntsy that ic almost nwesume, hechuse it will sovern oriselves and our childron and our deseeldnuts for miny yens to cone, I know of no other covintry that has so moch nilic land siattered around and that chooses to use tris probie land for the spceicl borefit of the private lnnds and vater interspersed.

To ask no such thine is the power of a sovereign. To know that the well-heing

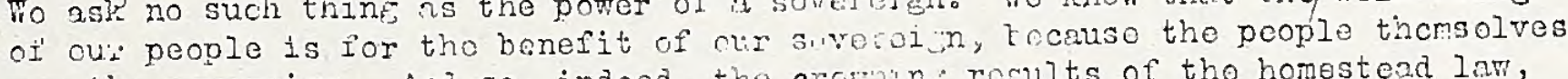
are tho soveroign. And so, indood, the crownin rocults of tho homestead law, as hns veon stetod $r y$ the Goneral Ind office. are the thousards of millions of chimneys over Kansas, liebras'sa and Inm, whero that p.. ?n porked successfully and by the up-iuizing and the raxting of titile to those lands, that is what made us tho nation wo cure.

Now, by the proper ascortninment of this wulic lind that is not able to ke deedod, even if reu nintei. buchure j.t cilildnit suport taxation, wo eontinuo in the crdinary progran of :ur Aserich Gorarmont to miks the ponle prosperous, individual woll..teine, and therebr mave the courtry rihat it is.

With that preliminary statenent, Gentilomen, I want to arnounce some rules hore that if you are not in nccord $\nabla i \frac{1}{4}$. thom, I would be glad to heve them diseussod. I om roing to ask eneh speakcr vi.en he cets up to wamce is rome and his

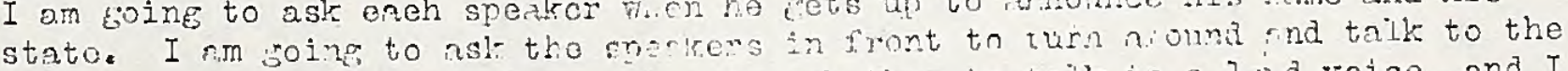

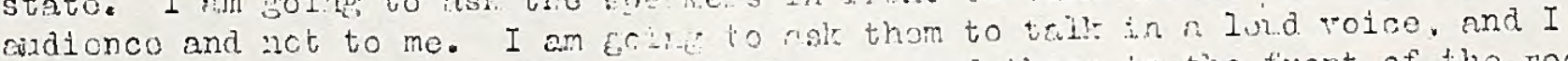

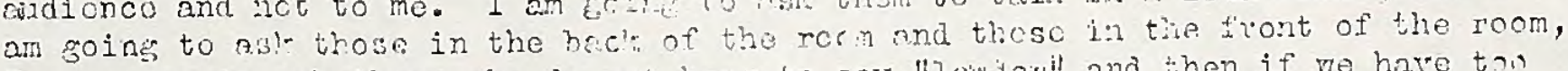

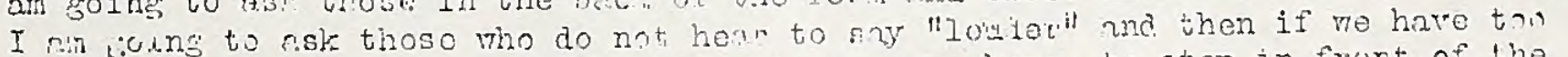
many "icuders", I am coing to ask them to eme up hers, tu atep in frurt of the mike. To have a loud spowivor here which till tiko just an cranery conversation, and ns some of you do not hrve a roice phich will cerm over the room, I am going to ask rou to come up hero. 
And ns there are a largo number here who will wish to be heard on these subjects I am coine to hold time on you and no speiker will spuak over five minutcs. without the eonsent of the Chair or the assembly, and no spenker will spenk trice on the samo topic, as Inng as thero are others whn have not spoken winn wish to be heard. That is in ordor to make a fnir debate and get all sides in.

All talks and all questions asked wo will ask to be confined to the topic under consideration. We are going to come th erforcenent, improvement, range survor and nany other topies this afternoon, fees and finarces, but this mornine: $7 e$ vish to confire ourselves to lieences ard permits, changes which wo think aro proner and neeessary in these rules and to bring out clearly here just what we nean and which va:- wo are exoing.

Anyone who wishes to talk bohind the mike is privilered to step up here and speal from behind the mike. I will onnounec the first topie for discussion. This is a teneral discussion. The members of the Advisor Boards, delegates here, and others in attendanee who are interested are more than privilezed to speak and ask questions on this subject, beenuce pe are sitting dorn now to take eounsel together, as we have been doing for tron penrs, to try ard elarify an issue and the intriguine part of it is that tiure is no answer in the back of the hook and we have the interestin job of workin it out step hy step.

The matter is now open for questions or remerls. Are there nny ehnnges in the present lieonse method of distribution, and furthermore, this topie is a natter of ereat eneern to this Dopartment. The disparitr in the rules of priority between distriets - - the dispariter in tho rules of priority just over state lines - what is rour wish - - that the disnarity he continued or do you think it would be more proper that we hnve the snme prinrity date established hore for the United States or by regions of uso? (A.ulnuse)

MR. FRANK MC ARTHUR, SAN FRHICISCO, OALIFCRIIA. (Cnlifornia CrazinE District No, 2): Gentlemen, that is a subiect which intertsts mo.

MR. CARPENTMR: If you will turn please, so ther vill all cot you.

IRR. MC ARGHUR: I think that the priority rujos should be established the same all over the United States, the datus in which the priorities we to be fisured, the same.

MT. CARPENTER: Come on up here, Frank, and talk. Frank is an old-timo oporator from Northern Californic.

WR. MC LETHUR: Ladies and gentlcmen, this is the first time I have talked before one of these thinss and I hope it vill prove to be all richt. The subjeet which Mr. Carpenter has sugrested - that of priority -. interests me. In District No. 2, California; we dated it back five (5) rears. Nor personal interest in the thing is this (I see $\mathrm{Wr}$. Clarke and $\mathrm{Mr}$. Jankins looking o.t me). Their messase to ne is that two yenrs out of those five yens I had no cattle on that range, but that is a selfish end of it. And in fairness to the people who own land within the district or noar the distriet, I think that wrenever the priorities should be established thoy should bo the came. Ail with that orief statement, I want to thank you for your attertion and will rit dorn. Thank you.

MR. CARPENTER: He, has given us an iden of the rient way for a stocirnan to talk ... right to the point.

MR. WOROII A. SMITH, SALT IAKS CITY, UTH. (Itrh Grazine District 10. 8): I have rever talled before one of those mikes --

IR. CARPENTER: Think how manj spenker:s we are goiner to break into this today, friends. 
- MR. SMIIH: Gentlemen, I hapoen to operate sheep in three difforent-statos here, Utah, Colorado and some in Fromine. It rather Gets me to tinin about what we expect to do in the shape of universal rovulations: It is m cindid npinion that the rules of priority should be universal in order to be lord. I r.a!'t think that this Department could make me have a pricrity in che sti..te thr.t I don't have in one state. I rould nsk for the same curlificnilon ir uris stito, that I havo in another state. That is the conclusion to which 1 irrs corre, nnd I think we will have to boordinate this thing back to th.s barrinniaf.

Priority in the use of the livestock hns ween a late contention wiih most ill of the livestock men. What is the date for the considerntion of the prioritu of use of the land? That quastion is not settled. It has not boen settled either wir. Me $\mathbf{~} 111$ have to get at a happy medium somewhere. Then we tnlk about the priority of use, thrt is a logal situation. Any rules and regulations that tho Department may make which are not legal, will not hold, even if the rhole bodv makes then, if ther do not conform with this act or the common law that preserved the use of the public domain relative to priorlty of use of public rosomeos.

In the beginning of this act, right on the first line, it sars: "Io stop injury to the public grazing lands by nreventing ovorerazing and soil deterioration, to provide for their orderly use, improvenent, and development, to stabilizo the livestock industry depcndent upon the public rance, and for other purposes." These dependencies are all the livestock that ras there at the croation of this law. It is self-evident that thor woro dependent -. you can't dispute that.

Now, I rould likn to see the Attornor General come out hore and help us solve theso laws and eot them into a lecal asnoct.

Nom, as to adjudication and ramification -. I think adudication is our most important question at this time 5.0 .25 the administuntive laws can be more onsily acceded to by the definite facts. Then the lni of adjuilcation - by the way, I have rot a lot of priority in my own proportios - o ownins about 50,000 ncros of ground in the three statcs. That is, I thiris, pretty nonr as henvy a land. holding as anjoody has.

But I vant to see the thing got into a start rist ofi, and not be like tho Forest Reserve. I remember 1t. They ave us first in ten-year permit, then they reduced us hore in Utah fifty or sixt.r percent. Thank rou, Echtloson.

MR. CARPENTER: Now, I didn't call time on him just becruse he mertioned the Forost Roserve. Now, we have hend from the combo; and the sheephorder. Both nisree that priority should be made uniform, that is as to dates or rulos, or whatever it is.

IIR. J. T. CONDIT, HAGERAN, IDAHO. (I Y.o Graging District No. 1): You have henrd from the sheepman and the cowboy, nid I ropresent the "flat-footed farmer".

RR. CADPEITER: Como on up here. I knew I wouli get ir "Dutch" winen I talked about thoso foot.

WR. CONDIT: I nover stood before one of those nikes before, and I don't

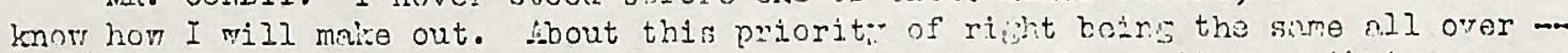
I don't see how that can rork. In the printes renorts hore, it surs that over fifty nercont of the graziors orn less than firty hemo of stock. I happen to be reoreseritins that class of people, in a district mene the priuriti, canses consideratle trouble.

Our Chaiman here told you that the hy-products tiwt tho stoek uned ard tho b"r-

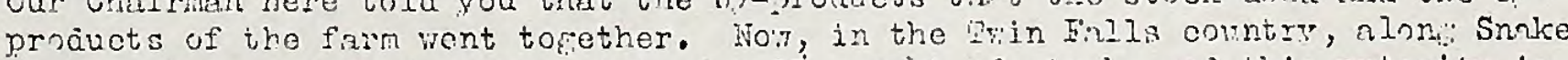
Riyer, they aro cll fumers, rith $n$ smali amount of stock, and this priority is causins: lots of trouble:

Men, before I Eet awa from here I expect to introduce a rasolution, which I don't suppose I will jet to work -.. but I an wini; to ark for it, tinnt the man With less than twonty head of stock that has more than the proper commensurate property, will bo allowod to put that stock on the mrage. I thant you. 
IR. CMTPETIR: That is what we'es a moeting. To have cot ali kinds of people.

MP. GUS PAPPAS, RIFIE, COLORADC. (Coloracio CrazinE District No. I): Indies and gentlonen --

IR. C.RRPEITIR: Come on up hore, Mr. Pampas. You run in tio states, don't you? All rigint, Mr. Pappas, pack it on.

MR. PAPPAS: Ladies and gentlemen, this 1 now to mo, and I don't knor if I can maire it work. In discussins tric priorities in the matter, as $\mathrm{Mr}$. Carpenter has snid, wo are goine to rork tocether. I will make my statement toring a fow words for all you hero in this meetin.

I have followed this meeting; since the Tarlor Graning Act was started, so, I sny to rou this, I mor it is for the bencfit of the livestock on the rane and to you pconle. This has bern what I have seen - that hin been discussed hy tho Boards - I think it is iliportant to cverrone of us.

I nm meribor of the Board on District To. I this year and I tolce mp part in the meetines, but I thin' tod is the tine fo: all of us th set this on a lecal basis and to sntisfy ererroody. So, what I sny on Disir'ct No. I applies on Mo. 8 , where the proper use of milic and orivite lanis are both comincd and peonlo havin property in Colorado como dom to Uthlh.

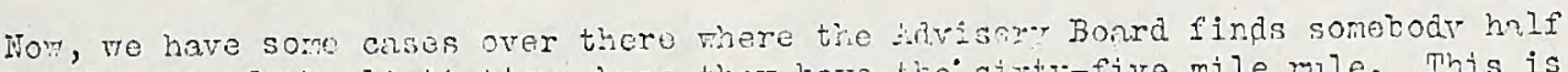
a. mile cut of the limitntion where they hnve the sixty-five mile mule. This is the time for us to sar about that one-hnli mile, or sixt,-five mile, or one-mile rule, and we should cet tosther and then fix it up.

And, also the prioriter rifhts - For instnme, thero was a man in colorndo allored his stock on the rublic land in the rester. atites, mae, let us say, fifty thousand or $n$ hundred thousand dolly rs, and thon lia kws that property in 1937. There is notrin to stop him investin: his nonit, ar there was nothing to stop him when this Act was onncted ir. 1234. Now, thet mint this man out and say to him he rill have to be a pionear here of ten yenrs ny you car't use this range.

I had a lot to sner on this subject, bit I hare formten it, so I will thank you very much for irur attention.

MR. CARPEMnt Nom, Wr. Pappas saic a rood bit in a few werds. lie is kickine on the Utah 6 rule, that is the sixty-five milc rule, he says it is not rifht. He is kicking on the rulc that arybohy who burs ma male has to lenor beforehnd the date of priority.

We want to hear from you men as to whether or not yn vint any priority mie, or any rule.

IT. VIJIER GILIER, METRCPOLIS, NEVADA. (Nova? Grazine District No. 1): Ladies and entlemen --

\begin{abstract}
MR. CARPENDER: Everr min mants to hnar rou. Come on up and stand up hore, please.

1WR. GILMR: The ti.ins that comes to my mind is that the conditions are so ver: different in each district. Tha Advisory Boards have made the rules for each district. It seems to me that the triditions are very different in ench district nd that the priority rulo that mint ann ver rell to one district mirint be very objectionahle to motiner district, and I am in favor of oach district makin its nimn priority ruling.
\end{abstract}

I don't think that two-rycar rule would be applicnble to Nevada ard perhaps our Iicvadn I rule mi ht not be applicable to Utnh. I don't see wher the Donntinent of the Interior con't uphold the priority rulincs, just as the co the livostock setup. (Aiplouse) I thank jou. 
IR. MC ARTHUR: That priority mile hurts anybody? You have objected to it, but hov does it hurt you?

NR. GIIMER: I think it will hurt other people, because it, will hurt mo.

MR. MC ARTHUR: Vell, if you don't have it, it will hurt me.

MR. GILMER: It will hurt because our conditions are so different. There is a very long period in Nevada, and a very different condition vill be found in Utah and Colorado: A priority rule of five years in Wevada mi bht not suit. It is soing to hurt the fellow in utah. On the other hand, if there is a short priority mle it vill hurt the fellow in Nevada. The Advisory Boards have, made the priorit:r rules and I am in favor of those priority mles for each district. 
:R. R. J. CNNWAY, CRAIG, COLO. (Colo.Grazing Dietrict No. 6): I belleve I can talk loud enough, without going up there. If I got up there and looked over this room, with all these faces, I might get nervous.

I believe in priority, absolutely. I believe it is too sacred a thing to be used as an instrument to deprive ueer $\theta$ of the range, who are dependent on the range for its proper use. I am in favor of the priority, where it can be used consistently with the land ue program, and I belleve it can.

MR. J, C. CECII, SUNTEX, ORE. (Oregon District No. 2): We, in Oregon, have adopted a uniform rale of priority inall of our districts. We have adopted two consecutive years out of five immediately prior to June.1934. Fe feel that the uniform mile is to the best intereste of all of ue, becauee, in our state ... and it must be true in other etates - we have men who graze both in oregon and in Ne vada, and in Oregon and in Idaho, and, unlese we have some uniform priority, it will be very difficult to adjust these border: Iine cae日s. Ctherwise we wouldn't care what priority rule you adopted; we could ue日 our two out of five rule for our own satisfaction and conventence.

MR. JAMES I. NIELSON, FOUNTAIN GREHU, UTAR (Utah lintrict No. 2): I believe in priority, ae this gentleman over here sald, and I belleve it is a sacred thing, but I do belleve we ought to be nearer uniform than we aro. I an a district advisor in Utah. We have a ten-year priority. All the rest of the districts have a two-year priority. The district on the south of us has a tramoar priority. Fie are on the long end, and I tinink we are too long. I believe $7 \theta$ should come nearer to uniformity on priority than from six months to ten years. There can not to that much differenco in the different dietriote. In districts such as Utah Nos, 1,2 and 3 , I thinle the conditions are exactly the same, or so nearly the same that thoe three districts at lenst ought to be uniform on their priority.

MR. CAPPENTER: I want to say this, so $70 \mathrm{can}$ ke日p on the topic: Mr. Cecil mentioned uniformity between the districts within the state. Really, the toplc here is uniformity between the states in ordor to make priority uniform thruout the United States, because there are no staterilnes that are not crossed and recrossed with Ilvestock, and the particular tnpic for discuesion nor is whether there should be uniformity thruout the ten states. If $7 \theta$ cen reach some kind of majority opinion on that, then I thirk it wuld be proper to take up a suggestcd rule to the Department as to whet date should be used, with the loast disturbance to the industry.

MR. WAILY MATHIS, ARIZ. NO. I: I don't think that we can $f(x$ a uniform time on priority of use thruout all of the western etates. I think it might be possible for districts; where their interests are overlapping, to get together on some uniform time. But I think our conditions are going to be so varied and so different that it $\nabla i l l$ be difficult to work that out in justice to all the licensos, and to make a uniform priority date. I think, in some places, it rould open the way for people to compromise on something, where it might take care of people who need to be teken care of. People who have gone out of business 10 or 15 years ago may come back in the district and resurrect something thoy have abandoned 8 or 10 years ago and sell it to someone who 1s trying to mork it out, and he would have to buy it to stay in bueiness. I think it would work a hardship on some who are entitled to stry in, to benefit the man who hae quit yeare ago.

MR. CARPENTER: I might sA, in explanntion, Mr. Mathis rung dom on the "strip", and when he talks about "years ago", he talks about cld-time wates r'lghts being sold out to take care of old operntore, I believe.

MR. STYLIAN STAES, PRICE, UTAH (Utah District No. 7): If have a general rule on priority. I would like to seo the question vory carefully discussed first. I recognize the fact that all of the Boards have different rulos on priority, but this is a rule that muet, at some time, become uniform, and must be regulated. If you give ue the opportunity to act at our pleaeure, to our interests and to our purposee, we will work vith you better than ever before. I firmly belleve that $7 \theta$ muet find a wey to be uniform. I do believe that it should be norked out so there wlll be no hard feelings on the part of any members of the boards, but there must be some unfformity. 
MR. CARPENTER: Mr. Staes is in fivor of a uniform rule. Let me say, gentlemen, that we didn't know whit lack of uniformity we would have wihen we turned these boarde loose to meke recummendrtions to fit their conditions. If you look on the back fages of your program, you will find it shots these variations. This is the first tice nis have had an oppertunity to sit dom nnd consider all these varintions. Wor ihnt reason, this is the proper time to dectde.

We will not vot $\rightarrow$ on this question this morning. This discussiun is dirested par-

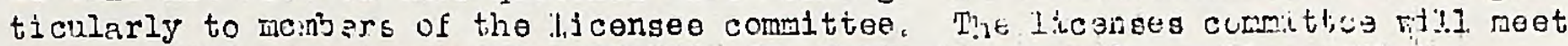
in the afternoci, tumocrom, and then, the follorine any, the matiei vilis. be brought back and finally declded in this convention.

JUIGE CAX, UTAH: I an opposed to unifors regulation and unifore priority nt this time, fer the following rensons: I believe it olli nmount ts an opening wed re whereby you rill de away with local autonony, so to speak, thrt has been givon to the livestock men under the Taylor Grazins Act. There are tro or threc

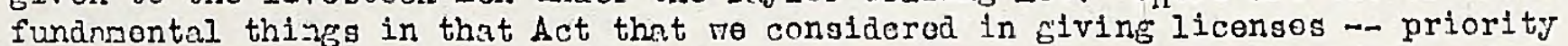
of usc, comensurability of land and rater, and propor usego of the rnngo. If you thake a uniform rulo of priority, thy not anke a untform rulo of land usago and commensurate rating of land and water, and, if you do that, you might as vell do away with every locel bonrd in everg aistrict, bocnuse, once you unify things, there is no need for a board.

The very principle of the Taylor Grazing Act was brsed upon the fact that we had different problons in different grazing units in diffcreat states nind differont districts. You ulght as sell do army with all tho districts, if you nro going to unify and centralize things. Why have 37 districts, or whatever it 1 s? Why not only have one district, under unffors rule, with priority and land use in all of it uniform. That is the other extreno, I believe, from locil autonory. I belleve that there are local conditions, which aro alfferent in the various districts and states, and at this time 70 are not rond to have a uniform mile of priority. I believo it should be votod dom.

MR. CARPENTER: I 7111 say this, before I rocoginize the next spenker: I think nono of us rant a fasclst state here. Fe want to koep our locnl autonom. But renember, wo are vorking tewards a permit systen, in which ench particular pioce of land and water is to have its proper use worked out, and thrt is to be the govorning fenture of teru permits. . So the time of what is done with priorities, when the Tavlor Act will not take into consideratinn all of the locel differences, all of the degrees of dependency of every piece of land, all of the various values of comensuribility that rater should have in the south, for inetance, and feod in the north,

Te are nor talking nbout the desirabllit of a unfform rule, which is being given precedence in the Ilcense日, until such tine as $7 \theta$ got on to perrits, snd rou should benr that in ruind. To are not going to destroy this Act whethor wo make the priorities uniform or not, because the big and controling fenture is going to be the land uses.

NR. FD MAHATFEY, GRAND VALIEY, COLO. (Colo. District No.3): It is hardir worth ov while to milk up hero. "I fust whin to ask $\Omega$ question or tro: I realize there is a difference in grazing districts, and theso differences have to be taken into considerntion. But I can't seo where it would work $n$ hardship on one district any more than on another district, to conply \#ith a uniform priority of use. There are sevornl gentlecen spoke on that subject. Thoir opinion is tiat it would zork a hardship, and thoj think it would work a hardship. They havon't shorm rhy it would work a hardahip on one district anv more than on nnotlier, in this priority of use. On seasonal uso. I can soo that very plainly, nnd solio other things that aight come up vithin the district, but, on priority of lise, I would like to have thooe who diocuseed that explain why it iorks $n$ hardship on one district nore than on another. I feel that we ohould have a uniform priority of use thruout the different statos, and not have difforent priority of use for different aistricts.

MR. A. H. ANDERSON, UTAH: I have llotened for sone time to this question, pro and con, ns to whether ve ehoula' have tho priority rights universal in the difforent districts. I an spealeing for a group of tien from southern Idaho and 
northers Utah, who are at present grazing in the rinter season in lievada Grazing District No. 1. Fo have about 75 or 80 thousand sheep. I mant to illustrate to you gentlorien fust what this priority quostion is doine to us. Most, if not all of these nen have a priority Ernzing rigit on tho public doman of sone 30 or 40 years, some of ther loss, but, sono seven or eicht or nino or ten jenrs ago, 7e vore overcromded dom in $D_{i}$ strict 2 of Uteh, and thero vas noro rock and wore grass over in Nevada. He noved over and connenced to graze.

Sowe of us have an oight or nine-jear record of grazing in Novada, and say 32 in Utah. Now, the Taylor Grazing Act coses along and finds us grazint: $i: 2$ Wovadi. They pass a priority rule of ton Jears. Utall Districts fand 2 have a different period of years - tro and three, I underetand. Nor, re have boen arra lons: cnough from Utah that thoy don't rant us. Wo have been array eight or nine yoars. I can point to three pon'in this audience who happen to cone under the rine-yon mile. Tirey have boon away frod Utah. nine soars; consequontly, Utnh don't mint ther. Nevada says: "Te passed a tey-year mile _ n to don't rant you; you don't bolong here."

These men have investmonts in comsensurate proporty, vorf hoavg investmonts. I would say that that particular district - southerm. I daho and northern Utal $-\rightarrow$ have heavior investmonts in connensurate proporty than any other soction of this innedinto rest. I thine 70 are nen $\pi$ thout a country. In ny particular aso, I om ay orm rnnee. I don't run on tho forest resorve. I havo invostrionts, private holdings, rango lands and it is a very hoavy invostment. Part of It I havo only omed soven years, tho rost of it ton yoars, but, on that part of uy property that I huve controllod only sevon years, I havo been deniod a perrit ir Nevada. Theso othor fontlenon, in the sane eroup, that have nine yoars, rere denied ontiroly for all thoir holdings.

It looks to we Iike, as the gentlenan before no snid, the priority right s'iould be uni vorsal all over tho erazing rost. It won't rorle any troro hard ship on the man in Nevada No. 1 than it $\pi 11$, in Utah No. I; tho sane condition oxists. If it is rise to havo it linited to tro jears in District 1 , Utah, it should bo just as riso to mike the priority rule two yoars in Nevada, and vice vorsa.

If I had ormod sy setmp for six yenrs in ono district, it ought to be justins Good as if it vas omod for six yenrs in amothor district. Our investments aro thero, our priority dates back nany jears, but we happenod to lonvo one district and start coning into anothor district to graze, but those linos that the govornpent drer, and calls district linos, loaves us out and drops us into a district that srys ten year priority. "\$o. don't mant jou". "Thon the other district sajs two yoars, and 70 have boon ariay wore than two years, and 70 are loft without a country. I think, by all noans, tho priority rulo should bo unifom in tho entiro grazing rest.

MR. CARPENTER: Mr. Mohaffoy manted to hear fron sonebody who had been hurt. Now, Jou havo heard fron somebody tho has been lurt.

MR. IIVER LEW; Alnwogordo, N.M. (N.M.District 5) I just arise to a point of order. $\mathbb{W}_{\theta}$ have been hoarine fron individunls as to their opinions. It secrs to ne that $\pi 0$ might not get tho right consonsus of opinion in that manior. A ran risine to speak should represent his grazing district or his stato. If we are. coing to listen to the individunls, over soventy-five percent of tho peoplc horc will not riso to talk on this question and you don't know wat they nre thinkine about.

MR. CARPENTER: Mr. Ice has raisod the point of order. Ho foels that tho discussion should bo linited to those tho represent districts or stetos. If I did not anmounce it this worning. I noant to anounce that this norning's sossion rould be opon to individuals, but that tho closing session, and before tho vote is trken, vill be confined to delecatos. That is, to the district advisors prosont, and, in tho conitteos, the votins will bo linited to those nen. But, at this tino, wo wish to hear fron an agerievod individuals.

MR. INE; With that understanding, I Hithdrar av objections. 
MR. JOIN ETCHARD, TAMPICO, MONTANA (Mont. District No. 1): I RI sponking partly for ryself and partly for the Montana delcention, tho roalizo the nocossity fol uniform priority. Five yeare is about the average that we want to go, prior to the cractient of the Tavlor Grizing Act. That is all. I have to say.

MR. JOHN MOMURRAY, OAJTEY, IDAHO (Idaho District No. 2.): I vant to quriify $7 y$ remarks by saying that I an not in a district that has boon lurt. We have not been a district long onough. In other rords, ne hive just beon hatched out, and I ar. herc with othors, ropreocnting District 2 in. Idnho. I as for priority of use and I an for local administration. I think that thooe non who havo to drift over state lines have a Erievance hore. I don't soe why that can't be adjusted betwoan tho different bonrds of the state, and let us control our ovm administram tion vithin our orm boundaries. We hnve threc districts in Idaho, and I rould siy thorc is tho sano condition existing in other districte. Sono of the conplaint was that our district was too largo.

The folks at howe want local control. I thin' I can speak for the sinll wen in our district No. 2, and that is ho rould like locnl control. Ho thinks thet this board will be entiroly fair, that they can sit thore on the hearth stono'ard work out thoir plans best for their condition. Why car't you nen that have a crievance get tocethor on state lines. I think jou havo a gricvance, but why talre'array our local control.

MR. GUS PAPPAS, UTAH: I want to a sk jou about state rights. You said what ve want is locnl control. Are re going to have a state fight or what? Why don't you rcalize that every one of these stateo is in the United States.

MR. CARPFITTER: Mr. Pappas raisod the point that ne iive in tho United Statos as rell as in the str.te. I rish to say, gentlenen, in order thent re don't got off on a tangent on thie, that tho controlling feature for the issuance of permits will be the proper use of land, and ne aro in no daneer of having ono hard and fast rule for all pernits, recardlees of priority.

MR. MCMURRAY: I rould like to tell those people that I an representing ny particular district, and I an tellins you what they would like. I think that rould be alnost a hundred percent. I an not an attorney general and I don't know the constitutionality of those districte. Thoy are just being set up. But I can't undorstand why thooe advisory boards can't cet together, where they overlap, and have an agreenent betreon tlien.

IR. CARPENTER: I al going to try to answor that, Mr. McMurcay said he was the nember of $a$ board of $a$ ner district. Many of you non have beon on Bonrds not for tio yonrs, and I daresny any newber of a board who has served for tio sensons realizos the alnoet insurountable difficulties of crosine over in state lino where the districts end'. We have tried to cet boards together there the priority conflictod, and, whon they are all thru, they fail to, roconcile their differonces and, for that reason, many of the nen here feel thore should bo one universil rulo.

\section{MR. MCMURRAY: Is that nore important than the local rulo?}

MR. CARPEINTER; No, it is not, and this, if adopted, vill be a local rule, adopted by the localities in the intorests of stabilizing the livostock businoss in order to follow the general procedure of livestock thich cross and recross state and district lines.

MR. JOFi i. MRUTTY, CHARJESTOWN, NEVADA (Nevada District 1.): I an a norber of the District No. 1 board of Nevada. Fe etarted in to handle our first rear vithout very much priority proceedines. The result was, thore re found osnacially on the winter sheop proposition - ve found nll the shoep in Idaho vanted to cone over on tho Fendover desert. We never got anyplace until wo nado a priority mule. We finally cocproaised on the state lar, which was oight years prior to tro years azo, some time. Even thon, I think that we found wo riere prett; badly crowdod, and wo will have to elininate. In fact, re did elininate sono on the \#endover desert. In our om district, ro have no trouble at all. But wo bclieve in priority over there, and the noro priority wo cet tho botter it rill suit us. 
MR. CARPENTER: Therc is no quostion about all of us believing in priority. but the question is phethor there should be, under this license nethod, sono unifor: priority in tho difforent statos.

MR. A. D. BROTNEIETD, FLORIDA, N.K. (N.M.District No.3): I think that re will defont the cntire purpose of the Secretary if ne ntterpt to make a uniforn? rulo on priority. If we can say right now that 80 are willing and ready to tlirow ovorbonrd all priority, I think every man in this house would jurp up and snj, "No, we don't want tint dono." Thy should we havo the sno priorits in Nor Mexico as re have in Californie or sono other stato. Thy have ndvisory bonrds if you don't sive then some rulos and resulntione whereby theý cain. control conditions in their orm district.

I think it is all rigint for aivisory boards to vor: in hariony, but not have any advisory board say that the priority in one state should covern the priority in anotlier state. If so, ro nicht as rell do and rith the adrisorg bonras and havo one control the entire ten peoter? states. Fe do not linvo oqual state statuts.s cdntrolling the public lands; tien why throw out tho mules that tine Socretery has civen us. I do not have the consengus of opinion of all of the Nerr Mexico dei-.-

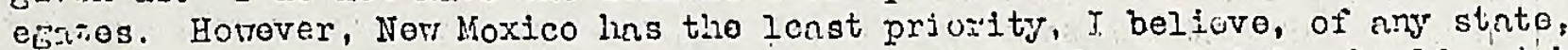
vith the oxcoption of that one-half genr prioriuy. We cortninly. should not lave a uiform priority ante.

MR. CARPENTER: I Want to sny, in explanntion, centlomon, so thnt jou vill understund this: In Nor: Mexico, tho priority date is Janunry 1, 1934 in all districts, and that is probably the lenst priority date. Nor, I aid not goine to propose here that we thron all priority out of the wimcor, becnuse I an not coine to start a lynching party. I knor the woy rou feel noout it. But re rre discussing the question of whether wo should reach a unifor priority date, at lenst as to crossinf stato boumaries. In Now Moxico, wo do not havo the sario quostion. Thoir allotmonts are pretty rell rorlcod out and they dave a priority date that is suited, but the states wizere a Lian, in the resular course of his operar tions uscs tro or threc statos, it is a nost acute question.

MR. WHINRERY, COLORADC: I Hight sny, in the beginning, that I lapponed to honr southing dorn here in tho lobby today, ocrly this norning, that su'sstantiates just hiat $M_{r}$. Cnipenter told us at tho start of this noeting, that he can no losger distingish vi:iul is a sheep man and risich is a cattlo man. I hoard a aan don here ask a firl at tho dance that was all this nootine about todar. Her. answer ras that "it is a nooting of the Grazing boards undur tho prilor . Act." "Oil", he sald, "that means cor boys." So I think that is a creat conplisiont to the sheep isen.

In the first place, I don't belleve that this quostion cuts ver. mucli ice. I tal- 3 it that any rulo we adopt now can not bo rutroacive. Te hive becn undor opiration of our rulos for alnost two years. In Colorndo, there is now $n$ unj. foraity of time as to oriority, alnost. For instance, I find tluat all our districts thore are tro years priorit, excopting No. 1 roquires thre jears. Tizon No. 2 only requires a inlf year. ITow, knowins tinc ienbers of the ndvisory bonds of iNo, 2, I belicve there tas a good and sufficient renson for that requtrenent. Thereforos if we chance the rule now, I velievs: Mr. Chrirman, wo wi.l only be accomplis sing tizis: that oo nicht opon a debacable question to sone pecrle tho have al roaciy been denied permits or liccnses. Those wio have already received licenses mould alnost cone under any cenerel mulo of priority.

So I can not sue just where ro are getting if ro take this out of the hands of the advisory bonrds. I a sure those of us in colornac don't caro. I an suro any ceneral rulo vill bo higher than nost of us have acreod." Mhen it cones to votine on this question, I nay have something noro to say, but that is all I. rant to say at this tine at the goneral neotine.

MR. J. PERISIS, CNTRTOIT, NEVADA (Nevada Iistrict 5): J an Mr. Pcrkins of Clark County, Havada, Distilet No. 5, Which is one Iilce Mr. VeNurray nenioioned. It is $n$ now one, and I believe that Daniel Nobster nust have had in sind that pa:ticular part of the United states rison ho objected to ncquiring tlis vestern torritory, becauso, in a Groat rany plncos, thore is no possibility for livestock to exist. In speaking of property rijhts, connonsurnto property ricisis, priority of 
richts, I bollevo tiant, in nenrly every one of tho difforent states vio are nffectod, tizoy hnvo difforont poriods of tino in wich to acquiro rt;ints. In Novadr, wo hine riant is lmom as tho stato wator rights, and wo linve with us horo

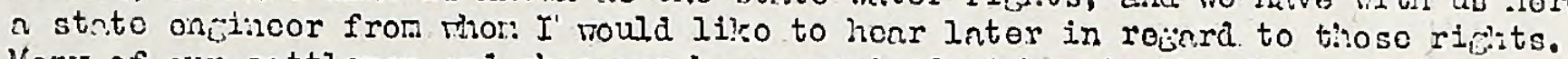
Many of our cottlozon and sheop:on havo acquirod rishts in tho istato of Nevada it considerablo expenso and they havo used the public domain in comoction vith thoso rigits, rilich thoy havo had joars and joars. Whon it comes to makitic: $a$ tro-jear poriod, and son:oono rith comensurnto proporty rights in tho stato of Utal or Idaho, and cosine ovor into Novara nid having an oqual richt with thoso poople wito hevo boon there yonrs and jears, it io haraly justice, and I as of tho opinion, no ins boon statnd hero bnforo, that anch diptrict should fornuhto its own rulos and reculr.tions in each stato.

Thoso ndvisory bonrds aro ablo to aoturnine whe rould bo applicablo in ono dis trict and rimt rould not, and, to nake a cenernl rulo of it, I don't think it vill over vork out sntisfnctorily. Tho Mavlor Grazing Act, as has bean stated, is for tho bonefit of tho risolo. Nor, it is joing to triso somo vor cnroful thought and considoration. You hnve got to forgot jourself in the wattor and rococrize tho ot:or follow's right along rith your om, and, if it is ovor to bo rincio a workable projoct, wo hnve sot to givo and havo got to trice. I lmor tho in centloran herc a ritilo ago spolvo of poople colus out of businoss, forcod out of businoss, that all they havo loft is ti:o richits thoy liavo nequirod to t':eir wator rigits in oortnin grazing districts.

If thoy rish to cone brals in ten yenrs, or tronty yenrs, if thoy want to cone

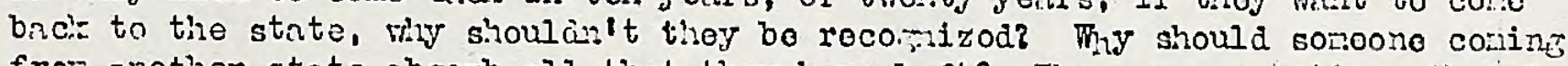
fror nothor stato absorb all that tho havo luft? Theso nro questions thit I thinic tizo corittoos rill liave to thrash out, tiat aro appointod, anc ticoy rill have to be broad onous so that tirey rill stril:c a happs nodiur for the bonefit of both tho shoop and cattlo, as roll as conts and loorsos.

MR. CARPENTER: I want to sNy a word of oxplanation, bocauso Mr. Porleins has rniscd a very vital point. Ho has raised t:o point that, undor stato lnis, risich distributod the ran;e in tho absonce of folorn lowlslation, aen hovo deponied on their rijhts, and that in all ther have. In Novada, tho nan nho did not clevelopo vator on tho raiso in 1926, rail on ticro ns a criminal. That is to saj, he violated tho cririnal statutos of tiso stato. Tilat ras tivoir ran;o

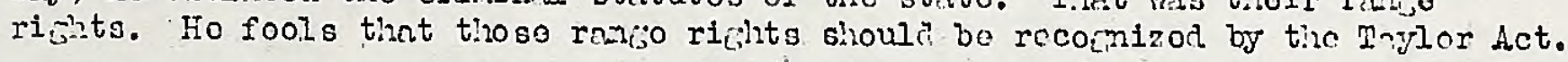

To renlizo that tho suprerie court has rocomi zod tho stato laws on rangos. meso

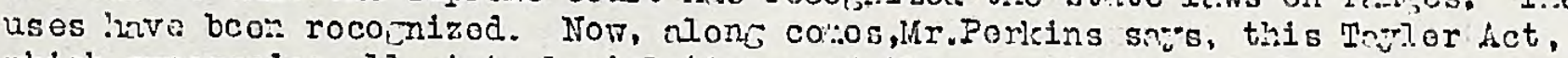
Which supersodos all state logialation, and tho quos'sion now js hor we can rizio a shocl absorbor in tho transition poriol fron tho tiro in raich pou oporated

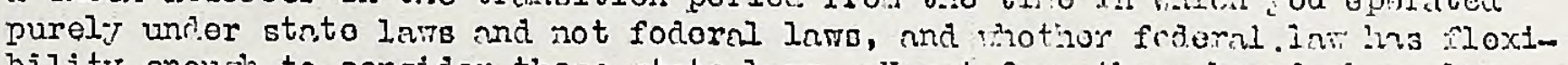

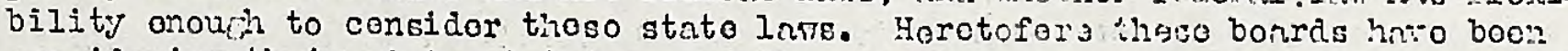
considering their stato. statutos, and the quostion wo nre rucicinis hore is whothor that coesi't causo soro grief than it doos gooc.

$M_{r}$. Andorson told us tho griof it has caused tien. Wr. Porlins vill toll us tho rood it doos thoso thet lavo it. It ion't coinc to suit overybody, but ti:e question is rhotior we aro coing to allor inter-stnte rovenent to run urinor the sane priority zulo i:l tro or aoro cistricts. Each bonri sticko on wint ti:er think their orm stato ri,ats are, so the quostion co os up as to whothor tio Dopartiant should not find thore is :oro criof in allo:ring tisis crazing in dispririty than u.soro roule vo dawor in allowine a unifom rule.

MR. JIM SMITH, CENMRAI, ARIZ. (Ariz.District YO. 4)! Me queotion this reorning is a verj sravo ono. I tlink we all nppyecinic tliat. I ropresent a district which, accorling to our schecule tite :oming, shor's our survor is corplete, and wo havo issued Grazinf licences unior a ruline poulans ionrer tho lappj rediur: of the ups nuc cowns of verious periocis. Forrovor, I think - li:s tize riatlorinn who

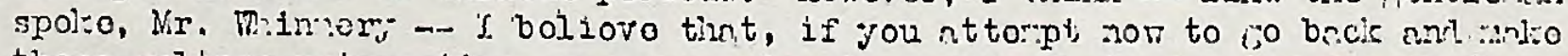

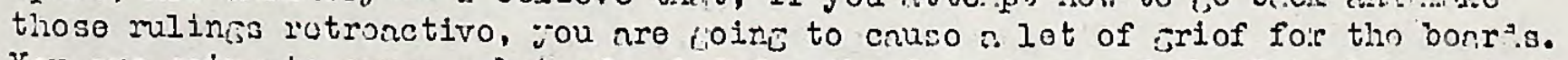
You are soin; to causo a lot of criof for tho depnrtant of tho Intmior, and it is roinc to ceuse a sreat anount of. Griof to tho ontire frazine puriod, nnd I can sce a cront arount of jriof that is soin; to bo caused horo todny ill roconciling tho viers of all the rion and romon ropresontod horo todar. Nor, as I. SNy, wo have issuod our crazi:as Iiconsos on a basis of tro yonrs out of seven. If wo 
stort in a.jai:2 - To have had sono little hell dom in District 4, Arizona, a.ti :0 don't want too much noro. Nori, if vo nro colrg to do this; let's co it nor. Lot's not mit one yoar or trio yenrs. Wer rplition is it should :nvo bcen done, but, if it has not boon done, ny opinion is it sliould not be done.

KR. CAPPEITER: Mr. Stith, from one of the nover districts 1 in Arizonn, fools ti2at, if thoro is nuthing cone rbout this, there should be no lon-or deln. You reilize thint the lonjer re so ritli different systeno of priorities, tise worse shrpe ve set in to charje t:an, becriuse rishts nequire on every chanjo in mule. Ho snjs, wiy wnsilt it cono.bofore. The rocoon was becnuse I dich't know wint tho boarls would de. Mo didn't lnow whit tho differoncos nero. So now re knom vint tho different districts wantod.

MR. MClRTHUR: Till yeu nsk jir. Srith this question: if sore bonri sadio a wrong ruling, rould thoy bo willing to clinnco it?

2R. CARP MNTER: I Till answir the question ayself. The boards have been

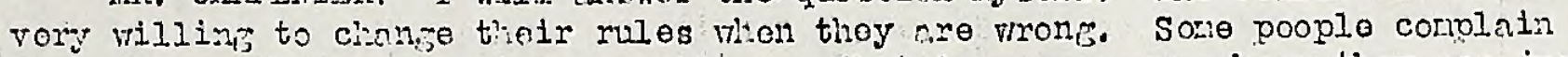
they chani;o their rulos too rnny tines. Thet ts necessary, vhero they nro just co:-posed of huran boings nnd can not got thon rigit at first.

UR. STANEY TIATT, COLORADC: Thero are two sides, of courso, to this prim ority mator. It secns to some of us that there $i_{s} s$ wide difforence in priority in states -. too vido a difference. In the district which I represont, it prob.. ab.y rouj.dn't anko nW difforence to anjonc rio has boon issuod $n$ liceaso in that district. Howovor, wien these boarls decilod on priority, eid thej not trie into consideration the anjle of the forrest nurabor beinf iurt? Mr. Thinnory of ry

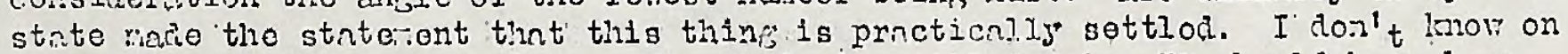
what basis he uakos that statoriont. It tsmit sottler yot. It should havo bocn settled, ns the Gertlc:an fros Arizona scid, tro jears noc, to strbilize the inaustry. Then tiaro is the invost:eit nreile. Peoplo today nro gotng out, nnd havo cono out, in tho Inst two yonis. The sooxer it is settled, the better. $\mathrm{Mr}$. Phiniory also sponks of the natter not boinj rotronctivo. I vould liko to asl tizo Diroctor of Grezing to oxpress inis viows on tiant matter of it not being retroactive.

MR. CARPENTER: I don't know as I understcand oxnctly what tirey mean by not boing retroactive. T':e Grass has been' usod up, so vo can't do arytining about that. That is over with. Irules tint we anke now wili ro irto tho 1937 reculations, of courso. Wo ravo jot to stry witi wlint wo ho dono up to tiris tirio, in fnirness to overgbody, but of course at this tine ve are considoring tho non reculations for 1937 .

Non, contlenen, it $1 \mathrm{~s} 11: 45$. Te havo heard exprossions about the adviscbil. ity of mating the prioxity rules univorsal. It rould be intercstire to listen to that porticular aiscussion, possibly the reat of the diy, but, ns ve are golng to take up rifforent topics wien wo reassomblo at tio o'clock, I an Goinc to surcest that in the next 12 ninutes of this nominf, sossion, if thero is going to be a comproriso roachod by this comittoo that vill roport this out, that sono kind of tino or period of. use 7111 have to be sugiested here, ard re rill have to soo how ve can sot the states torcther on this metter. I ronlize this: Sono sas. "Lot's tizico this doy, or "that day" or "the ot:ior clar".

Contlomen, if you take the conto of the enactront of the lnw, or take a day in Docorber, in July, or Aucust, when the districts wero ostablished, and you sny on timt date they will cot richts. If you do that, there rns nobociy on tho winter rngo at that timo. There is nobody has a richt. You can't take a particular chr and pick it out and trick everybody. by ewing they have got their rights as of the.t dny. You and. I have rorkod too lonis on that proposition. It is perioc of noo that gives a nan a rance privilege. It isn't linpponing to be thore on thet particular day, and you knon $1 t$. So this mattor has to bo constdored and justified. That is a rango privilego? If you rake it $n$ dn vhon there msin't anjory on the ranco, then nobody cot a privilogo. That is nonsonsical. Me aro coins to have to set a date that can bo usod in faimess. There may bo differencos betroen tho statos and districts, but cortainly there nust be ono rulo for ovory Unitod Statos citizen, or it roula seea to ne it vould alaost violato 
the Oonstitution, rilich says ono sta.to can not bar a ran froa anothor stato from comin: in. It ray be thint you vill wht to koep sore locnl rulos for those tho ho not cross out of tho district or str.to, but, just for tho purpose of this last ton minutos of discussion, I ns: soing to proposo this uniforn rulo: thet one full soaso:'s use boforo tho onnctinent of tia $\mathrm{Ing}$ bo consiciorod tho acquirom nont of onough of a range privilaso to ontitio a san to priority, and that thon his caso vill bo jukgod on his proporty qualificntio:s.

I would Iilso to henr on that topic in our for reunining :imutos. Do you thi:l: that ono full sonson of uso prior to oinctient of ti:o Act rill caso lons, friof than tho prosont nothoc we nro undor. I bould Iiko to honr from $j$ ou now.

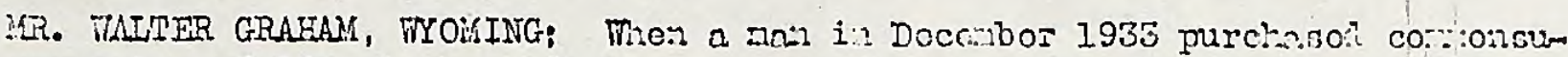
rato proporty and livostock, and enterod into t?:o Iivestock businoss, ho wns cn-

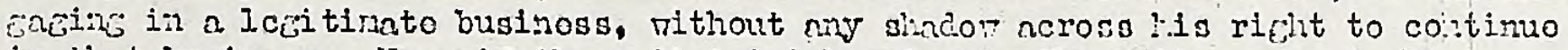
in thet business. Now, if those district bonrds, in tho nnttor of priority,

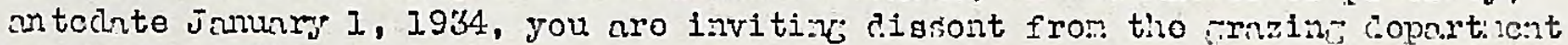
and Iocnl action fron thoso thom it affocts. Tho matter of le, itilinte priority is a difforent subjoct altogother and cri bo donlt with bj locel oivisom boaris, but tho risht of anyono who had his ticlict and wes on tho bont 1a Doccr:ber 1933, cail not bo abrosntod. The Act itsolf snis that notilins nequirod after Jamury I, I 934, could bo irrantod as crodit, oithor in tho mattor of con:onsurar tion on priority.

MR. CARPEINTER: That $M_{Y}$. Grahn has snid is truc, Jith this qualification, that tho failuro to rocowizo proport hold good until Julr of 1935, nnd, aftor that timo, it was to be disrognrod.

MR. MHIIE, COIORADO: Tho mattor of prioritios has beon bost fixed up by districts. I thini overy district bonrd has triod to fnlso the bost rules for thair district, Consequontiy tho rulos roro mincio to koop as rany of t'so pcoplo in their om cistrict taicon cnro of $\mathrm{ng}$ nossible. In oritor to mato this oqual, I clon't think thoro is any quostion but rint uniform priority, if it could bo arrangod, rould bo a gose thi:sf, but I thinle it should bo rith n fivo-yonr mini-nu basis.

LIR. WAX COHEN, IDAHO: Thon this Trylor Act ms first cronted, wc all lookod forvare to the priority in t?:o uso of tine rano. Stocleson pare all bohind it, becauso thoj thought thoro noulc bo priority, we rould jot tho uso of tho ran;e that ras aijacont to us, thit 70 had boon usliz. That is why ro vorlion for it and that is why it ras passed. Nor, to saic a unfor: rulo, as hias bock proposod, a uniforn rulo of 10 or 15 yonrs, that uist apply and wo woula bo for it. In tho ovont it rould bo a fer $;$ cars, thoro aro n fou hn this aro goinf; to be hurt. Therc rill bo sorio people hurt no jinttor what jonrs or what lon tll of tiro is bo ing usod, but, if no nre going to servo ti:o :insos, it :.:ust bo done by locel bonris. To lenor tho conlitions of t'ie local usors. Thoy nro tho ones that should bo consicierod and taloon crio of. Paon, if thoro is an rango after that, thoso lian hino tho right to use this iand, but tho first consideration nro thoso who havo boon usine it for jonrs and jonrs and have t:oir sotwup, nind I for ono ar viry aucl opposoc to tho unifori rulo, unloss it bo for $r$ Ion: perion of

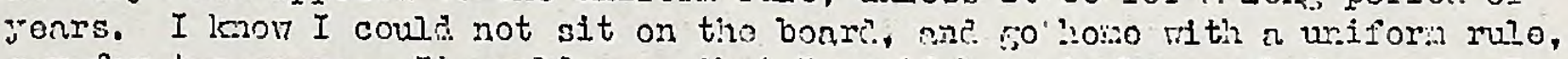
siy for tr:o jonrs. It would zonm thet I would have to hinvo a bodycur.r. I

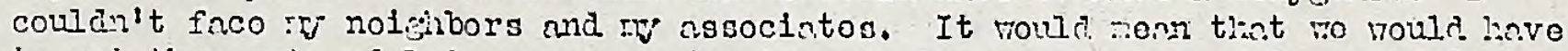

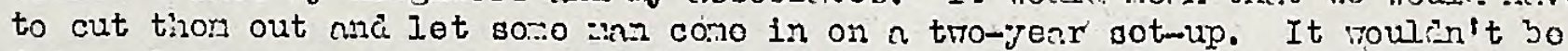
fair. I for ono ar vory ruch opposed to a unifor: rule for all of the statos.

MP. CARFLINER: It soos rithout saring, of "courso, that if Mr. Colion is achinst $a$ tro-yoar rulo, he is aighinst $n$ ono-jorr rulo. 

JUGE COX: It npponrs to Eo, on tho question that has boon plneed before us
that no aro probnbly quite dividod ns to rliether or not thoro siould bo n uniforta rulo or whetior it s'iould bo up to the loeal bonrds. I rould sucuest that, w:on tio stetos nre cillea upon to voto on whother or tot thcy fovor a uniform rulo or to Jenve it ns it is, thet thoy bo asked to voto on thit proposition, nnd, in nidition to that, to inte a reconrondation - onch board of oneh stato inke a rocon-.:endation - as to hor lon; tio priorit; siould be. Tion, if tho proposition passes for a uilifor: rulo, tho dopnrtrant rill linve the consongus of opiaion fron oach stato or bonrd, ns to hov lone the priority poriod s'zoule. bo. If tizey voto it dow, I don't know wint the attitudio of the Departzent rill be, but thent apm penrs to ree to bo a $\mathrm{wr}$ to oxpedito it. Lot them roto on the two propositions.

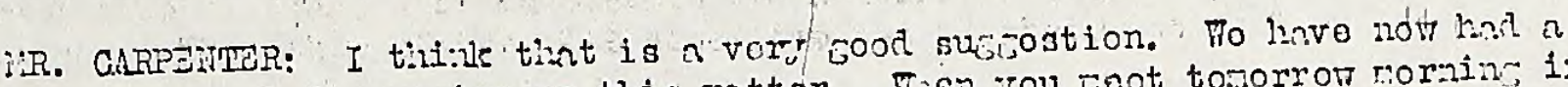
very broad seneral iscussion on this metter. Tien you neot tonorrow norning in rour statc com!lteo roons, nal jou dotornino rour national conittoe, you botter put sor:o rood fighting zon on rour nintionn eoreitteo, bocause thoy will havo this question up, and you lanc. "better instruet thon is to rinothor jour state fnvors or opjosos the unifors rulo, and, if thoy favor it, what tho thing the roquirements should bo. Instruct your celestos riti. croujl leown. Do ant givo thon so littlo leowy that there is mot?:ing they eni ro but voto ono ras.

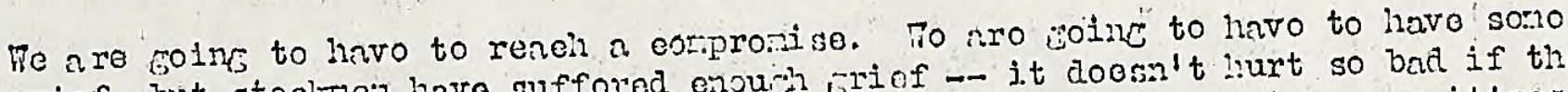
Griof, but stoclean havo suffored enou-h friof - - i.t doosn't liurt so bal if thoy oll have a voice on it boforo it is reacleal. Fo want the various eorrittcen to Ga in there with a full conorledio of wint the stato dologntos dosiro. Thon thoy rill spond tonorron aftermoon t..rnshi:le out rosolutio.. , which will acain bo brou $\rightarrow$ ht baek to tho floor nise clocicied. It is $120^{l} \mathrm{elock}$. Ho rill adjourn until 2:00 Pls', and berin pror-ptis.

(Rocess 12 IToon until 2: OO PY)

DEC. 9,1936 - 1 FIERHOONT SESSIOH:

(Lootinn callod to orter by Cliniman F. R. Cnrponter, at 2:OQ PIS)

IIR. CARPENTER: Gontlezon, vilo re are miting for tho loud speckor to be turned on, I vill jare a for armounee ronts. You vill notice thet this noetinu is

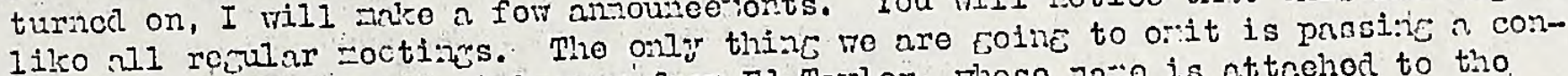
tribution box: I Got a tolecrnil from Ed Thylor, whoso na:0 is attrehod to tho Bill, and he vintod no to roeite a little bit of pootry he eomosed. Ho was preventod by iliness fror attendinc tiris seoting.

"Hor:e; home rule on tilo ran;o,

There the sheep and the herefords not stay,

Where soldon is heard in discournoine word,

Ai:d tho stoclion have goratining to sav."

(Applause and laucilter.)

Now, I want to $\varepsilon^{\circ}$ over a for littlo minttors of procodure that I have beon ques-

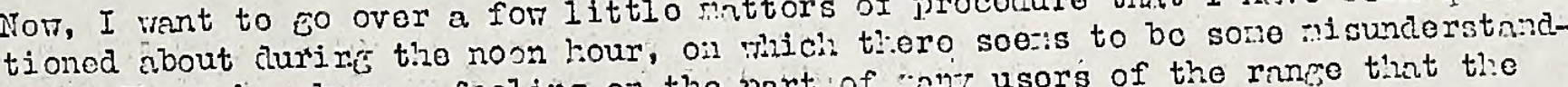
ing. Tliore the boen a foeling on tho part of ind usors of the range that the Cistriet advisors have stolon tho show, t?at thoy havo tho solo oar of tho Depertront, or have tho Departiont's sole onr, whichover way grou rish to put it.

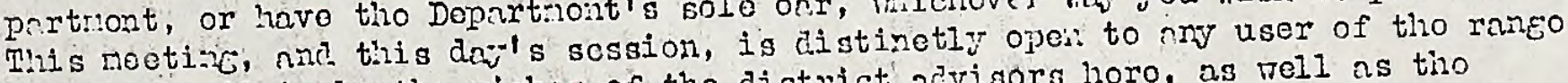
and I take it to be tho pishos of tho district advisors horo, as vell as tho demartiontal mon, that thoy mnit to hear, not only fron distriet aivisors, but fror all usors of tho range wino feel thensclvos aciriovol fron ans causo.

That is tho renson ro rant it understood thist no one rill bo shut off. Evorione is going to bo honrl, within tho linits of tho milos wo havo outlinod for diseussion. But, espoelnlly, this day is goire to bo for those not on tloo bonrds, bo eause the boards, after this dai is over, will have thoir resolutions, and the finnl day nobody but board nombers will sponk on tho rosolutions and sobody but bonre rocibors $\mathrm{HIl}$ vote on tho rosolutions." 
Hovever, at this tine, wo. want to honr all parties. So I mant to acain oxtend nn invitation to any one to:volee arvthine they wish.

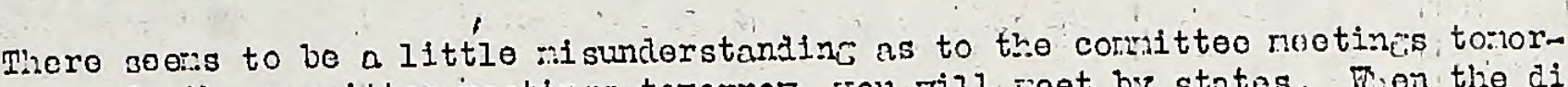
rov. In the conmittoe jeetings tomorrow, you will seet by statos. Wion the distriet advisors of the state nre assenbled in the roon, they enn decicle vintiner they wish to havo othors bosidos distriet advisors in tho roon or not, and they ean inve then in or not, just as thoy desiro. They nill then diucugs those questions, and tho last hour of thoir nomine nooting will be dovotod to elcetinc reabers of a national comittoe. On oneil of the siz subjoets, they rill. eloet two rioribers. Utril having so many liconses, and boins in two re;ions, will eloct four norbers. That is, Refion 1 , Wich is the root side of Utah, ana Region 2 , the enst side of Utail, vill enel eloct tro tiembers on ench of tho gix antional corrittoes. The other states 111 el oct tro nen on their national corritteos.

Then, at two o'elock tosorrow aftemoon, foneral comittees, after Iistoning to cenornl diseussion and statos' discussion, will sottle down to one topie to concontrate on, and bring bnek to tho genorel neeting, which rill open up Friday at nino o'cloek, their roports.

As to where theso state a aetincs will ke held: That inforantion rill bc obtainable at the information riosk on the mezznino floor. Tho neetinso rill all be hold in this hotel buildine. Arizona rill reot in Roon 202, California in Roon C-38, Colorado in Roö C-41, Idrho in C-43, Montnna in 2n6, Novadn in C-42, New Mexieo in 138, Oregon in 207, Utah in the Jade Roon, vhieh is Roon 100, a largo roon, on necount of tho sizo of tho clelegation, ard Broning in Roor: C-37. Thero vill bo signs postod over the roons. Thoro will be an inforintion desk on the nezzanine floor wian you zet horo in tho morninj. Most of thoso roons aro on this floor or tho floor above.

In tho afternoon, the nationol eorrittees: Tho eorattoo on lieenses will reet in Roon C-4I, the comittoo on pernits in C-43, foos and finanees in 138 , ran;0 inprovenoints $\mathrm{C}-38$, range survers $\mathrm{C}-37$, anc le 1 jislation in $\mathrm{C}-42$. If jou ire in coubt as to whore your roon is, if jou will inquiro at tho informtion dest. thoy ear speodily sot you ricit. We are anrious to start theso comittoos off promptly on ti:es in the nornins.

I have been inforned of a numbor of nisunderstandings since our noriling nooting, and I lavo also boon asked to continue the digeussion of the inportaree of priorities in licensos. We havo a nuvibor of other sujjects fust as important to co ovor. I foel it would bo unfair to tho eonittcos and tho state delocations not to have those subjeets coverod in the genernl assoribly, and particularly to civo the elnnee to those who are :lot distriet advisors to eone hero and express thonselvos, whothor for or hfaingt tho siston we aro using.

For that reason, I foel we should eover tho othor topies. Then, if we have any ti:10 loft over, 70 can go back to this intrigulne subjeet of prioritios ajain. But I feel, after our tro-hour diseussion this worninc, we havo a fair eross-section horo, and we havo sonotling for your stato cormittees to tako up and lator sour notional eomittoe.

The next subjoct for diseussion is tho nattor of porrits. I feel that the r.ost volurble thinc that can be dono at this tino is to got $\Omega$ distinet eoneept in all of our ninds a to whet $\Omega$ pornit under tlio Tarlor Grazing het is, or is goine to be. Then, after you havo reached thore, you ean loole back, and seo better whet tho lieonsos are, and rou ean see tho rathor insignifiennt position vhich prioritios will play, relatively, in percits, to what they are now plarine in lieonsos, and possibly it will oivo you a botter perspoctivo in any furthor diseussion of priorities here today.

Preferenees in the issuance of grazing licenses shall bo given for the proper uso. of the land that they omn, uso or oceupy. Any other eonsidoration besides tho propor use of the lands in or noar tho alstriet will have to be consistent with vint has boon done, to hook up tho proper relationsilp botwoon tho publie and private lands. In other rords, under tive permits, 70 are oblifed to bo eonsistont with tho other purposos and provisions of the Act. That doos not nean, nocessarily, hovovor, that priorities sink into sucl a lov stato that they havo nothing 
to do until everything is practicalij fixed by tho property set-up, bocauso jou all know that section 3 doos not sey that rarge priviloges rocosnizod and acknor lodgod aust bo consiatont with tho proporty set-up, or must bo consistont rith tho propor uso of land. It sajs it reuot bo consistent rith the othor purposes and provisions of this Act, and one of tho othor purposos of this Act is tho stabilization of tho livootode industry so that it does not 60 cloar out of oicht and the stabilization of tho livostock industry lo one of the purpoces that nust bo adhered to and that all rulos must bo obligod to bo consistont with.

Now, you havo copies of tho Act. Mny of us havo otudiod it for years, and will probably bo studying it for many noro zears. Ultinately, of courso, courts mill pick it up and study it, ard finally, the Unitod Stntes Suprome Court Nill undoubtodly say what tho autiors meail when thoy rrote "proper uso of lands" and. "rançc priviloces recognizod and ncknomlodged." In tho noantiso, it is our dosire to so interprot the proper use of thoso, words, contlonen, that fie $\nabla 111$ havo no fear of any decision of aly court, in order that wo ray. have no undoine to do in this adrinistration and this adjudication of range privilegos. That is tho endeavor of the Dopartment, and that is tho/roason for the taking of this rido counsol hero today, and for this dobato.

Now, a perait is passod prinarily, to give privilegos to honesteadors, sottlers or land-omors. Nearly all of the poesiblo users cone within thoso throo classos, so they aro relatively unizportant. Everybody is oither a homostonder, a sottler or a land-omor, bocause, if ho lives thore, he is naturally a land-omer, homesteador or sottlor, but he is givon a pornit for tho proper use of the lands and rater he orms and occupios, if rithin or nonr the diotrict. First, no havo the Eroat stunblinf block; hon near is nonr? And oecond, what is the propor uso? Is the proper use the denonstrated uso nado liorotofore, or is the propor use the use for that particular type of land, by reason of its vegotation, clianto, rainfall, and so on, wich it is bost adaptod to, whothor that is wist it is nor used for, or shother it is nor boing usod for socething different.

You realize that 70 now havo tro aistricts wirich have the carrying capacities comploted by careful rango. survoy, and acrood upon by the stock zon. That is, in Ner Mexico. To have one pieco of ranco in Colorndo District 2 rharo allocation's havo boon Inde and allotrients acreed upon, and there is a possibility of only one appenl out of tho entire district, wilich doubtless can vo fixod up. So we are coine to havo, beforo vo go thru this year 193\%, sono kind of romulations for pormits. Then a pornit is issued, it is oblizntory, uncior tho torms of the $\Lambda$ ct, that it be renorod, provided the peraltoo las compliod with tho rulos and rogulations of the Secrotary, and providod its fatlure to bo renewed rould impair tho socurity of his ootmup, if it bo plodrod for a bond fide loan. So that is a persit and it is a vory serious matter to co into.

So 70 want to soe what rour idoas and recormondations would bo for thoso ruloo for tern perrits. In other words, while we have boen soeleine the propor rolattonship of land, we practically perfor a marriafo corerozy. whon wo cive tho tor.t permit, because we hook up, private lands and wator with oome rango, and, while there nay bo. changes for conservation and othor uses, at the sawe tice it was Concross desire that public rance bo used proporly and bo usod so as to aive the proper use to that which tho settlors and poople of the wost have found that whey could patent and use wi.th thoir sotaups.

I believo that, boforo. coing further, it wight possibly bo bost illustratod if 70 cot sone quostions from the floor, as to this distinction betreen a licenso sotup and a porait setup. I an goinc to ask, if there aro any questions, that you asle the at this tige.

NR. J. E. CONDIT, BAGPRAMN, IDAHO (Idaho District No.1): I rould like to know tho difforonco botroon a liconso and a pormit.

MR. CARPENTER: You Fill find on - I think it is - tho last pase of your progran, ther o aro sot out the alstinctivo differencos botwoon Iicensos and perm its. Iiconses are purely an adainistrativo sotwup, undor the broad porrors civon the socrotary, to do all thinjs nocossary to carry out tho purposos and provisions of thio Act, whoreas pornits aro joverned bs a spocific statutory 
cuard. Iiconson, as you know, are terporary, and for a yonr only. Pormits will bo anything up to ton yours and is a runrd anninst a falluro to renor a perit, for thono in cobt, and ti:oro aro tirco or four othor aistinctions botroon liconses and porsits tint aro sot out. You will find tion in tho procram. It is Exivit 4 in irour prörn.

MR. HCARTHUR, CAIIFORIIA: Fon on tliog intellicontly issuo a pornit until you lnow the value of tho whole property as comparod rith tho value of tho rango land in wicl the liconses are issuod.

WR. CARPENTER: Mr. MaArthur has nskod this quostion: He seys, "Por can you intolli, jently issue a porpit until you know not only tho carrjir, capacity of tho rair;o land, but tiso valuo and use of the privato Jand.s and mtor, and ti:o projor rolntionsilip botwcon tho two kinks of linds." Iror, rentloron, ho lins hit the mij. rigit on tho hiead. Fo cris not ro thet, aild thet is the ronson ro lavo not tried to do it. Failing this accurcte cato ns to the carroing capncity of the ranio, as to the corr:onsurnto valuo and tho dopeadent valuo of tho jpivato lands and vator, and failine a noro propor rolationsidip that cris orily cor:o to us after wo got that datn, 170 havo had to rnit until aftor wo cot it.

This past year, we havo boou vorkine on a raso survoy, which has boon complotod in ohe district. In sore statos, it vill. bo compotoci. tis yenr, aili so on, in

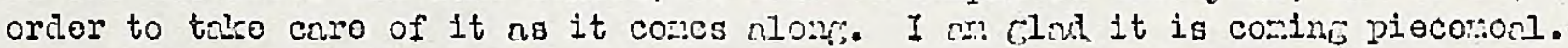
I ar clad. we will znve a chance to cone into o:2e district and pork j.t out t:oro. liy fooline has nlmo bcon that nll thoso witl: licensos should bo fivon a for rears of a liccnses, and a full jenr or two of tiro in rialch to perfoct an, apm penl, in ordor that, bofore tloy aro doprivod of any property rilcit, they may have a full year. You realizo that, in tho aproals on those licensos, tho rocur lations have sotton out so late in tho spriar; that, by tino tiac tho apporl is thru or porfoctod, the uso of the rano io practicnlis over bith.

That is duo to the finct that this is a nori Act, tint re no setting up ranchinory and operating it at tho sne timo. But, on tl:o pernits, it is a sorious-onou; is Lnttor, I tais it, thre, aftor tho dobato today, the ray recomone. that thoro bo a continunnce of liccuees for n period of yonxs, as an adjustrent poriod, nnd. axplo tire fiver to porfoct all eppenls. Nov, I Hoilt scare you to conth. It is not so bad. To nro not acquaintod ritr. it. Fo havo $n$ first-linnd acquaintanco witir liconsos. Te foel pretty bafe as lone; as thoy have tho suro ratin;s on it as tisey usod to.

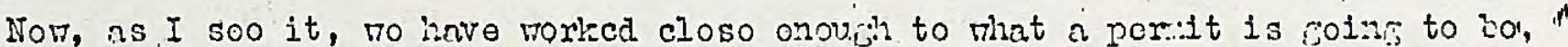
that the transition crn be ranco rithout bndly discomoding the industry. The depondoncy of t'iso proporty is colne to be of prime importance, and d.cpenciency, of courso, is a floxiblo worr. As to hor much importanco a pieco of property vill bo zivon will dopone on its corronsurato value and how rinner it will support for the poriod it is neccssny to support. Its copentency is not hon depondont tho operator is on tho public domnin, wut hor dopo:ndont that particular lond is on the public doinin.

The:1 we hino tho word "noar". Thon no havo a lnr;c number of com:onsurnto properties, sufficiont to oxhust tho corroin; concit struction that has been put on "nonl" liorotoforc, those who nro nocrost in tho point of ailcs and accossibility vill ta:o it, up to tho full carroing capacity of tho ramo, and those not so near vill bo loft out. Ono district in Utnh hos rado all atterpt to put in practico tho "roar" mulc. misoy first ande the rule 35

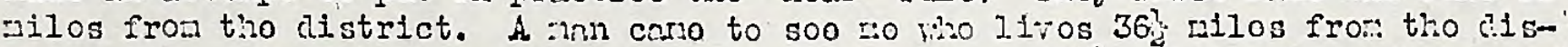
trict. I said, "M!o Board could chango thoir. rulc to 36 milos. Thon thore rould irmodintoly bo a wan living 37 ailos nwr wio yould protest." Soonor or lator, to protoct. jour snnces, you aro coini to havo to dran somo 1 ino. 
W:o ro you aro gotne to put "nonr", what kind of construction you rill put on $1 . t$, is $n$ inttor you yoursclf will liavo to dotoriso, and you will not bo nblo to. c. tor: ino it until rou havo tho corploto picturo. I hnvo boon 71 th this, in t1:0 adjuilcation of rangos: To run in a rathur snall arc, particularly tho con can. Thoj don't liaro the ri:olo picture of a district, and nono of us lavo tlio rinole pictirio, of course, or t:o tan stritos. To rialo tl:o riclit uso of those public lan?s, and to set up tiro rifint relationohip botwcon tho public and tho privato lands, it is oin to bo nocessary tint $\mathrm{y}$ ou huvo n jicturo. Thut could bo cotton in tro rnjs, as I soc it. If wo hail ::ono: onou, or ability onourh, ro could

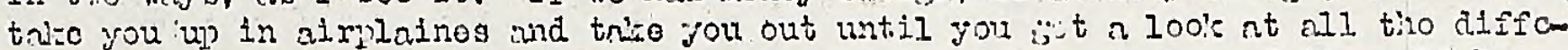
rert jroportios, and all tho difforont rovononts of livostock, and it would vo a narvolous clia:ce to soo the antire picturo. Mlant is not practicnl.

T1:o noxt bost is to roduce it to paper and got it on a mp, and re are cotting maps. Ti:o cowittco on raico improvononts and the comittco on ran;o surveys

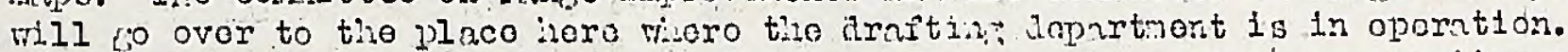
Thoso of you in Colorndo havo pro:nbly noon t:.o inrrolous statis nnp gotten up by tho forost sorvico, vilich s':ows ti.no omnursip of tho entiro state of colorna, whotizor thoy are omed by tiso county, tho stato or tho nation. If you can lpice. turo wour on state in that kind of rin, or your orn diatrict, and thon suporm

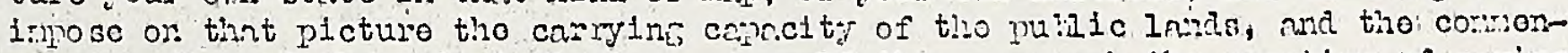

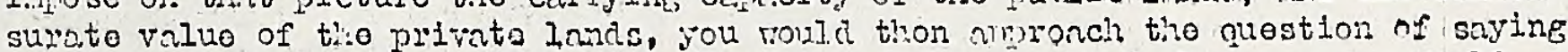
what is the dojendency reting of ench pioco of priveto land, iocnuso rou rould pick out its relntion to tise ranijo, nnd you would !non whent it lar raisoz, nul what its dopondoncy ras, and tho cotornimetion of tint deponjoncy would be tho deterintion of tho periit.

I foel that wo nocd havo no fonr of stoppine into a lopondency proposition. I cortninly would not liko to bo a pnrticipent i: any land plan in which tho uscrs dil not havo a vory louk voico in innt went on, bocruso rision was not givon to $\Omega$ for people. Fo havo got to wot it olloctivoly, this wat, nal tho anin

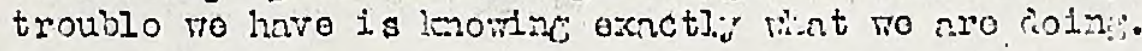

To nro going, now, to try snd Alscuss a perait, ne to rint ro fool should bo otven the min onjhais. in thuse rulos for permits, lccause there is going to bo a set of rulos woksod out, c:nk, if 1 t is your wish, wo can pursuo the ncthod wic used on liconses. You wll ror:ontor, whon wo first enpronche? the ratter of liconsus, tho trepidation with wilich the industry appons:od it wh so gront that, even wion wo hold soetings in ovom state, and I rent bac: to Hrsiricton, anc it vas all worke? out and apjorovod by tl:o socrotemy of tic Intorior, still no nore unviling; to havo thoso j.1cense rulos until 70 cn:o bncls and hold four sootin;s in t::0 rost to soo whether those rulos would do for a prolininary sot-up,

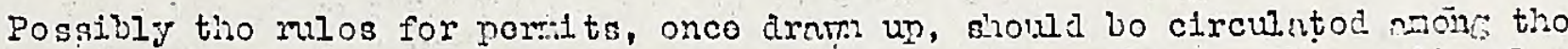
boards, stould bo discussod in somo nootines, aid posstbly nuotier nationnl nootinc. Mhey aro nuch moro irportait than tho liconso rulos. Ho mant to knor vinat you thinl ribout permits, wiet'sor you aro in a hurry to got thero, sor you want to cot thero and what jou think tisor. slovuld bo wh:en you arrive. You lanor' as auch about this las as to the privato lands and rator, that tho privilogcs prectically taiso tho rance. I wourd bo clad to get questions ond surecstions fror you son as to hor you.viow this menter of araving up eithor tho procoduro sido of hor wo should do it, or the sido of what thrit aliould bo.

MR. MaARTHUR: Hor much of this CCC vorts fill tho raingo usors bo roquirod to pey in the sroct by-and-by. I think, njrelf, tlise cattlo sen slrould pay for their orm rango irprovozonts, wht $\pi 0$ cartalily canlt afford to poi tho nrount it is costing to build sconic roads and trails and got oj with tho centllo businoss. 70 can't do it. "Do wo havo to pay thit bili?

WR. CARPENTER: Mr. Mahrthur'g question. is as to vinothor tho cost of tho CCC

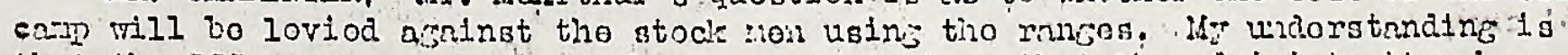
that tho CCC carms aro pnrt of tho owor;oncy sot-up that tho ndrinistration has put into offoct to holp ond tl:o depression and cive orploynont and trainins to 
young zon, and no part of that will be recovered in a special assessnent against any industry, that it will fall into the national debt and will be paid out of ceneral taxes. So the stock mon will pay no nore for the nork on their ranges than vill tho average person in goneral, the avoraze tax-paror in tho United. States. Does that answor your question?

MR. MCARTHUR: Yos. I hope it wili work out that may.

MR. CARPEINIER: I don't see any other way that it can rork oilt.

MR. A. R. MEATER, POST, ORE. (OrOGOn Dietrict No.5): DO I understand that thero iill be no pertits issuod, oithor temporny or otherriso, in any district, until there has been a range survey aade?

MR. CARPENTER: Ur. Tenter wishes to have it romethtad as to thether there vill be pemits issued bofore there is a complete rang survey. Iron, gontlongn, there will not be. If you vill turn to your circular of May 1935 , and your circulnr of Mar in 2, 1936, you vill find strted in the preambio that these: 1icenses are issucd to give us timo to make thoso suriogs, and, until they aro conpleto, we can not zo under porrits. You will find tlint these ljeconses are notilssued under section 3 of the Act, but only under section 2 of the Act. It rould bo unfair to rou, unfair to the Departzent, and to the industry, to try and go at this in a half-balied way, and, rithal, it ray take several yens. You will find on jour proeran the nuiber of years estinntod for $y$ our particular district, with our present facilities. The Dopartient feels that they nould rather not do anything until they can do it richt, Does that answer your question,Mr. Meater?

\section{MR. TEATER: I thin's no.}

MR. MAX COHEN, IDAHO: I mant to ask the quostion as to whother those peraits vill be interchaneable for sheop and cattle.

MR. CARPINIJR: Peraits rill be interchnngeablo at the option of the owner of the perait, provided tho chanie doos not interfore. Wh th the othor users of the ranco.

\section{MR. COHEN: Will that be Governed by the locol boards?}

MR. CARPENMER: Yes. In that caso, the other usors of the range will, of course, havo a voico.

MR. STYIIAN STAES, UTAH: Sinco peruits are coing to bo for allotnents, I wondor if we couldin' give overy licensee a separato arca undor a license and see hor it rould nor:.

MR. CARPENTER: Mr. Staes aakes this very practical suggostion: that, wheroas nost pernits are based on an allotnent, eithor individual or connunity, that, bofore pernits are issued, a trial and temporary licenso allotnont be civen in order that they can have a kind of trial harnoss put on thom, in the allotiont business, to work undor for a yoar, before it boconos hardoned into a permit. I would like to hear a discussion on that natter, if you have viers on it.

UR. D. H. ADAMS, IAYMON, UMAH (Utah District NO. I): I don't believe it is the proper thine to do, to put that tri,il harnoss on until the survey has aciually boen nade. If you put the trial harness on, and someone trios it out for a year or two, and then you como bacle and take one of tho tugs away fron then, you night have somo trouble. So, keop the liarness off until you get the survoy completed, พould be ny advice.

HR. CARPEITTER: The way I understood Mr. Staes supgestion, that, oven aftor wo hive all the data ready for peraits, and the range aurvol co:plete, thon we should five just a trial allotment for one year. Would that peot with your ideas?

MR. InkMS: That answors 1t. If the survo has beon completed, thon it is all richt. 
VR. CARPENCER: In othor nords, if I properly understood Mr. Staos' sugostion, it ras that, cven when cverything is collocted, when we cail assombie these boards and lay before thon complete maps, when we can afroe fith then on carryine capacities on overy piece of land, then all that is done, still, before the term pertits thorsselves issue, that a trial allotment be made, at lonst for a poriod of jears, bofore the perit is cono into. I nould lilso to know whother or not' that neets vith your favor, bocause those sugestions, centlonen, will probąbliv bo cariod out.

MR. HAI HAMIII, HOPE, N.M. (N.M.District No.6): Wo fool that ro havo bocn timru a trial poriod in the last tro years, and that wo are roady for torn per:its, and if wo could have soncthing in tho ford of, say, 75 percent, for a tch-yonr basis, lonving 25 por cent to tako up the slnck, it rould cive us somothine concrote to go on.

MR. CARPEINTER: Mr. HAz:ill is from New loxico, thore the ranco surveys are the nost nearly corpleted, and whoro tho question of "nonrl does not ontor into the discussion. He says that he would liko to have the pernits issue up to a certain percent, and he suscests 75 per cont, that the Departaont hold.25 per cont slack in the tempornry licenso method, for future adjudication, bocause he snys, for two yonrs, thoy have beon terporizing alonis and thoy would liko to linve it settlod.

\section{MR. J. D. WOBIITT, COKEVILIE, WIO. (Wro. District In, 4): For thlat roason?}

MIR. HAIMILI: In our stato, wo havon't hal a creat doal of trouble. Wo have 90 per cont satisfaction in our district, and tho bniks, and othor zonoy loaning concerns, are talking a bie interest in it, and that would bo the reason, for the benofit of the stock nen on that rnigo.

MR. CARPENTER: Ho has a vory different condition fron what you havo in Wromini and Utah. They have had what arountod to nllotments in that strito for rani, Joars. As Mr. Harnill sös, 90 por cent of tion aro satisfiod vitl't?is terporary set-up, and lave beon for a poriod of joars. So lio feols that, in his region, at least up to a certain percentage, as soon ns maps aro cospl cto nnd acm copted, they are ready to Go.

MR. NOBLITT: Thon it would secn to ne re would have to appronch this proposition frow an angle that would talse care of Ner Moxico on a difforent basis than othor states. Can we do that?

MR. CARPENTER: Prccisely so. That is the bcality of a rocting like this, that $w 0$ can get Group to asle for what it wants. That is the r cason why wo havo those nootings. If 70 got shut up in Fashington, we rould only soo our back yard. Wc have, represonted in this room, every condition in the range states in the

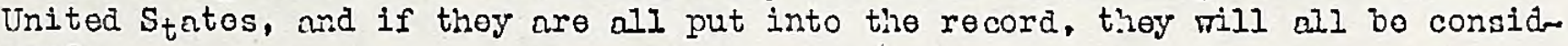
erea.

IIR. J. M. TILSON, SAFFORD, ARIZ. (Arizona District 4): To iz Arizona havo sonetime of the sase situation. District 4 , as you vill notice on tho progran, has the fiold rork cormloted. In our district, wo havo sone apponIs ponding. In. the majority of cases, howover, wo ficure tho thine is settlod: Te have some nppeal cases that are very ligint. Some hrve an allotmont or connunity allotrient. We fcol it is moro or loss settled. They hive gono, so far as it has boen all thorizod, to build foncos. If 80 go back and say we have cot to issize tomporary licohses for anothor yonr, thoy will say "Why". Our ranees aro divided on the noarnoss of mater, as a' rulo. 'I rould say 75 per cent is sottlod. Thoro is hardly any question of thoir boing remopenod.

MR. CARPEINER: Mr. Wilson livos at Safford, Arizonta, and, dom there, with tho cooporation of tho Soil Consorvation poople, we liave nado $a$ very comploto raze survey, tho rost comploto ranco survoy in tho United Stntos. Tho condition down thoro is that tho wesh and the runmoff from tint soil has boon so eroat that the Rcclaration Sorvico aro in daner of losing sono of tioir greatest roservoirs and so creat surs of nonoy havo boon pourod into that rogion to malso a completo survey of that ranco, to protect all of tio azriculturo in that valloy, that der 
ponds on the rances. As a rosult, $M_{r}$. Filson is talking about where they have a complote ran. Thint is riv he foels as lie does. Fo can rot tnko one rule and fit it all over the Unitod states. He has a different condition from what most of tho dologates in the northern states have.

MR. O'NOIL, MOKING: In cnse of sale of the stock and the land, aro these poraits transferrable, and to that oxtent?

MR. CARPEIVISR: Tho perrit WIIl not transfer viti. tho livestock at all. The pormit or license vill transfor only with the perrit, ard there will be no cut on transfor.

NAR. M. C. JONES, MISE RIVIR, MONTAITA (Montana District $\mathbb{N}_{0} .5$ ): Supposing. a case there a party is active durine the period of the corncisurability, he has comonsurable property and, at tho tirio ho qualifies under the period of pptiority richts, then ho bocones inactivo durine tho licenso period. At tho time the pernanent perrits are issued, if he doosn't ret in, then is ho required to hold his peace forever aftor.

MR. CARPIIITER: The question is, if a ran is not stockod at the tine peralts are issued, whether ho is out - $\rightarrow$ is that it?

MR, JONES: YeS.

MR. CARPEITIER: No. He can get a non-use pernit and hold his rights. He noed not bo stocked-up at that timo.

MR. JONES: Hor is that GOine to stabilize the industry when theso wen have been licensed, to use this priviloce, and he is cut of and this other nan comes il丷.

MR. CARPEITIR: If it is necessnry, in order to utilize the rance; to issue sone teaperary liconses, to talro up that slack for the poriod that nan is out, thoy will. be issuod, and also a roesonable restrietion will be placed ion lis cornaback, so that he can't cone in in one jur.p. Ho noy havo to como in in tro or three years.

WR. F. D. HIIIIMAS, MINGRSVIIIT, UMAH (Utah District 1vo.3): I mould just like to ask a quostion, inaguch as you are on the subject of non use, hom lone this non-use privilege will be Granted. For lonij will thoy hold good for?

MR. CARPEITER: I can't tell you that. Ti:at is sonethine that you non will have to act on and recomond. That wi cht bo different in different districts. But it will be reasonable. It will be for a reasonable period and under rensonali e restrictions.

IRR. J. M. CONOVER, FERRON, UTAH (Utah District NO. 7): I think that the se licenses and peritits are a vory serious question. I don't tininl that one district should be held back on its pernits becaus'e so:-bociy olse is not up on thelr work. I thinl, as fast as any district is qualified and is ready for a permit, that ro oupht to izmediately civo tinea these persits, bocause it is going to ostablish the stock industry. They can get roiley and co aliead and do somothing as soon as they get their perifts. I don't soe miy, if somo districts should be slow in sotting their priopities and commensurato ratings norked out, sono other districts should bo hold back.

MR. CARPENIER: It has always been the inteation of the Dejartment, as fast as ro had a set of data, to 80 into that district with a peruit syston, even though districts around it might be on the licenso systom. Thoce is no intention to hold back any district viren this data is rendy. Fo liavo thought of settine up a trial district in so:e stato this coming yoar, and profiting by any nistakos that ve shall undoubtedly alke, in orker that we can use it in other districts. riat is an inducant to you to got in on the first district!

IIR. MARION IEE, MHATCEER, ARIZ. (ARIZ. Nistrict, NO.4): I nould liko to know, in Arizona District 4, if wo aro coinc to bo compollod to tako the S.C. S. figuros on tho carryine capacity. 
IRR. CARPENTER: Mr. Iee raiscs a cood, Lot point. The Soil Conscrvation poplc havo beon in that district in Arizona and get the carrine copacity. Tho carryine capacity on the so-called crass rances in Arizona. Te havo two types of ranes dom there: Grass rane, and a ranc wiero thoy don't havo grass, but they just have an annual frorth of rocds and cactus, and tho lario part of it is scencry. In that second part of the ranee, we have had a violent disagreonont between tile stock nen and tinose fovmment nem wo have ostinated the carryine capacity of the ranje. Nor, Mr. Lee wants to know rihether the stock nen are coins to have to observe the carrying crpacity of from zoro to 2 , that was placed on that rance. This is the netiod of approach that has been rorked out: At the Teeting of the chaimon in Was'ington, Jour chairann, Mr. Filson, was thero, and ho brought up the sare question you brought up, an? we sont for Dr. Lordormilk of the Soll Conservation Service.

Mr. Filson said there rero ten sections thot ho knor cors could fet fat on, if they would fence it off. I asked thoso fcllovs if they were riline to fonce it orf and anke an experinent, and, if the stock nen could prove by practical denonstration tiat; instead of carring zcro, or ono, or two head to the section, it would locp scveral more head, and still not ceteriorate the land, that that could be the final answer that the Govemrent rould have to accept, as nell as the stock wen. Non, ry unierstaidins is that they are fencinc off rimes, on wich one aren on tlis scenic rame will hold :o stock, ono rance vill hold the estinate of the stock Lien, and one rance rill hold the estimato of the Government, and that, after a for years, the stock nen tlienselves will be invitech to E० out and look at those rances and see rinich is proper. I know of no better way to solve those difficulties.

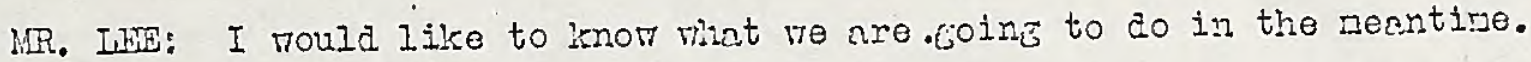

MR. CARPINIER: That man has a veri practical and persistent habit. (Iraughter). To are going to do what mo have had to do in the past. We are goint to get alone the best $7 \theta$ can by a corproniso, and just na; along with this until we knom surely mat your carmine cnpacity is. You probably mon't set all tho proper, but, in the nethod rineroby tho stock nen nalko recormendations and the Departuent act on the recomendations, you probably ron't be hurt baily, and re will find a pothod of cetting tocether until no set thoso facts dofinitely deter uined by actual experiment.

I want to say tinis: Me have not found any creat difference in carryinc capacity of the rances, where ne have a crass rane. I an soing to call on sone New Mexico people that have had sone cxperience, coing over these sovernment esticates of corryinc capacity. I wonder, $M_{r}$. Cliver Iee, if you could say, somethine to the stock nen on the capacitics as found by the rance surveys, as to hon they arreed with the stock nen's estinate of the range. Mr. Leo cones frori a district and a state whero re hnve been thru mint you Eentlonen rill havo to go thm in adjust. inf your practical experience rith covemment surveys and data.

MR. OLIVER M. IJE, AIAMOGORDO, ITET MEXICO. (Nev Mexico Grazing District No. 5): Ladies and Gentlemen, I have been asked to answer a quostion that is just a little hard for me to answer at this time. I :.ent to say this, that in general discusston with the men makin the rnnge surveys for the Department, I have found very little different in the csitmate that they put on as to the carring capacity and the estimates that the boards Eenerally have found -. so slight a difference that it is not material - and in just a very fen cases.

I think that we are coming close to an azreemont in nearly every district that has been classified up to the present time. That is my understanding. Now, I want to say to you that that statement is made from general conversation with men doing the work and not from study ingthe actual data that therr have gotten up. But that is my general impression and while on that question, we have gone so far in some of those districts that we are non roady, I Eelieve, for the term permits. And in my opinton, it is vory desirable that they be issued at the present time.

MR. CARPENTER: Thank you, Mr. Lce. 
MR. J. J. BALIARD, MC DERMICT, NEVADA, (Ore Gon Grazine District No. 4): Ladies and rentlemen --

MR. CARPENTER: Is this a question, Mr. Ballard?

MR. BALIARD: Well, will be a little more than a question:

MR. CARPEITTER: Everybody wants to get a tri at this mike. You come on up.

MR. BALIARD: The only mike I ever stood bofore before nas a two-fisted Mike, and I came out second best. It looks to me like we are chasing tho provcrbial kold at the foot of the rninhow. I had fondly hoped that this year ve mould be grantod permits, but it scems, from what I can hear today we have to wait another three long years. Ever heard that before? (Lau ihter) And further than this, a susgestion has just been macie and it secns to have met
with the approval of $\mathrm{Mr}$. Carpenter, that after all the cinta is in, instead of Eiving us the permit which wo had hoped for, that there is to be another period of probation of several years. Now, if this thing takes on that way it is going to be too late to do the present spcaker any good. (Applause)

You can't even fict close to a banker without him asking you how your permit stands, if you have one? No, I haven't one - I havo a license. What clas's is that? Class 1 or 2 -. whatcver it may be. Have you any assurance that that will be perpetuatod? I can only sny that Iandon said in his last spcech: "No man knows". (Lauchter and applause)

Now, therc are some things that re shovld lattend to in this lifo, for I am told that the Judgment Day is going to be quite a busy day and they may not have time then to attcnd to them. So, Mr. Carpcrter, and ladies and sentlemen, I cannot subscribe to this. Now, I want to siy that I am speakins for mysclf and not for the rest of the delegation from Oregon. I thank you.

MR. MC ARTHUR: I have spent the last two ycars giving Mr. Carpenter hell, and gotten no place. But, you have sotten up there and criticized him and not offered any better solution. I rould like to have the facts Eiven. The criticism I have made of him have been to his face and based on the facts as I saw them.

MR. BALLLRD: I want to go this far -- I certainly would not put this extra period of prohation on at a lator date. As soon as we get these facts,

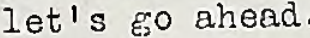

MR. MC ARTHUR: That is all right with me.

MR. H. S. HHINNERY, GUNNISON, COIOPADO. (Colorado Grazine District HO. 3): MR. W. S. THINNERY, GUNNISON, COLOPADO.
I believe that the man tho is deperdent on this question nore than anyone else
is our financial man at home. The banker sooms to have some encouragement as to making his loans on these liconses. I would like to remind that gentlemen that he is in a good deal bctter financial condition today to make those loands with a Greater security on these liccnses, than he was before under no control.

I believo another thing, that perhaps therc are otinor things to bc considerod today when we are discussing this proposition of licenses and permits. It is just barely possible that Consrcss may docide, within its wisdom, to put all this srazine under one departmont, and $\mathrm{Mr}$. Carpenter, I don't believe it would be out of order for me to say that my pcrsonal wishes in that matter -.. I háve lone oxpressod nyself -.. that the grazing should be in one Department, and believe now that it should be under the Department of the Secretary of the Interior. (Hearty applause)

It is possiblc that that will comc about within one year or two years, because it will make an entirely different setup. I believe that the Secrotam of tho Interior has touchod upon the right form of Government whon he put this Act under home control, if you ploase, and I heliove it should extend to the other power. 
A yenr aro I urged unon this meeting that we get down to issuing permits as soon os possible. Even though last yoar I askod for it, I am not rorried so greatly about it at tho present tine. I foel that our people are becoming nore and more satisfied with the license period until all this investigation is made, bocauso tho boards are going to five this man the same that ho had the year before when he falls in the richt class today.

The banker neod have no uneasiness noout making him the loan. In referonce to priority, I think that is a big question and I want to say at this time we should Ye in one department.

MR. CARPENTER: I misint say you nouldn't find any difference in putting this in one department, either hero or Trshinton. ment.

MR. WIINNERY: A Ereat many of us have maco up our minds about that Depart-

WR. CARPENTER: I don't want to raise that question at the present time.

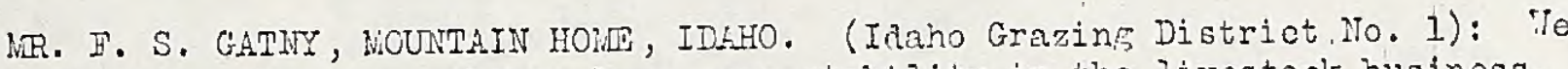
are at the time whon wo ought to have more stability in the livestook business. I was very gratified to hoar you say that the Bill ... the Taylor Bill ‥ provided for the stabilization of the Iivestock business. I was afraid you had overlooked that point in tre law, in your secming desire to stabilize the land values.

Now, I feel thrt mistakes have been made in putting too much importance on ralles richts and preferenees in the lands, ospecially lands with no connection with the livestock business, and I refer porticularly to a lot of homesteads that the livestock men have heon pay ing a nuisance fee to the homesteader on, to kcep him still. Now, your Department is puttine a prior richt in those homesteads, which, I believe, is wrols, bocause the homestond value will be raised up until po cnn't keep it up any more.

The stability snould be put on now in the livestock business and, I believe, we aro ready for the torm permit in most states, but still, I believe, we should Eo slow enoush so that we are cortain we know what pe are doine. In my four or five Jears experience there never has been a time when the livestock businoss was so unsettlod as today. There is no stability to it. The bankers are foarful. The men here are also afraid of what is going to hannen. There is a roof of fear on the livestock business today, and I trinl we can clear awai this fear by issulng term pormits. I beliove we are ready for thom, in order that we wili know where we are going from here.

The banker doesn't know, we don't know. Te can't sell or buy. 'There is no tradins in livestock or Iand because of this uneertalnty, yet I say this, that wo snould be carcful. We don't want a permit like the Forest is sued here for ten years, except thet they reserved the right to reduce it for range control, they reserved the right to reduco it for trensfor purposes and they reserved the right to cut the allotment. No man can run under those ton-jear pernits.

But, Mr. Carpenter, we are ready right nov in all these districts for these term permits. What is there to be afraid of? Why nre you fearful of this term permit? He want this term permit to stakilize this livestock business, as it provides in this Taylor Bill.

A man, who is a Basquo, camo to me a rear ago, and he said, "That this fellow Taylor going to do? I hear this Fellon Taylor going to take this rnnge avay, and I hear we all have to go just one little place over out of rejion. That the hell the matter with this fellow Bill Taylor?" low, in ny opinion, there isn't anything the matter with the TAylor Bill. If there is anything vroue it is in us, not knowing the facts, but $I$ do believe that they know the frets well enough that r.j the noxt spring they can issue a permit, not a liconse, next aprine.

As to tho question then of the lencth of time, I cannot say, oxcept as to tho facts, but I can sey that what we vant is a ten-year permit and if next year is 
the time and $7 e$ are ready, we want them because we want to know where re are and whit we are doing and where we ço from here. I thank you.

JUGE LEROY H. COX', ST. GIORG U, UEH. (Arizon: Grazine District No. I): I belicve we should five some eonsideratinn to what the gentleman sust drid. I beliove this, that we have the Department here vith a hanaisul of mun ir in: to mako a survey in order that we may have the ten-yenr jer lit, and the jivestock man has boen ignored. So far as tho eost and worr and anxity, thrt ho hes had. Because the Department said, we have a handful of nen to vorr ten retrs' time. I believe the Department can do something b- expeditine trese surveys and puttin; on onourh men. It would not eost any more to do it in one yenr tinan in three or ton years.

MR. C.APENTER: Jud Cox has raiged a point that the propram nt precert is not very first with the existing persomel, and as long as these torm nermits are deperdent on the proper data, we should "et a lurger personnel. I want to mico a statement on that matter. Te have a fumere ounified to make ranso survoys. Everyono can't do it. It thises specific trainine and oxverienee. There is, however, quito a little foot work and drrfting work. We have asked that we use the emersoney setup -- the C. C. C. cans -- for what help they ean cive us. Te have taken selected young nen from the camps -.. some of them hikhschool bovs, some of thon collefs boys -. ve have oiver thom intensive courses in drafting and in workin section lines for rames sirvers. To bave tiree schools -.. one in

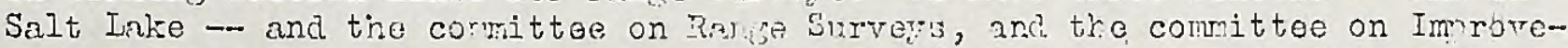
ments vill visit the draftine room tomrow. We have another ir. Alkuquerouo and anothor in Reno. Iikewise, we have in the fioli a number of boys who aro lenrning how to walk the section lines ard mele a careful estimate of the vegetation and palatability.

Te are not waitine and sayin; that pe can't ho our work because we neod more appropriations. That is a hard word in Tnsininton. Out at the Zoo, near Connecticut Avenue, they have a bird thoro. Its toncue hins been (j)lit so/it ean say a few rords. And Thenover a visitor comos to tom, they take hin out to Conneeticut Arenue to hear this bird, and these ars the four rords he sars: "What about the nppronrintion, what about the anproprintion, fhat about tho appropriation?" It is eustomary for all Governmont penple to hollor about the appropriation. To hnve tried not to do it. It is tma, as Judce Cox sars, and we have made a franle estinate to you on the sheet in your romram, on when we ficured the work will be completed with the trainel mon and mon ve are trainins, but it will tako some time. Any questions?

MR. i. C. JONES, TIST RIVER, MOITAIIA. (Montan Grazin Distriet No. 5.): We have had no range surver; but hrve had some experienee vith the range conservation men and from what I can learn -.. well, recently we have had somo ex-'. perience with these fellows in the ran;e conservation prosran ard from our ex-" perience with these fellows, we would be a lot better off if we had never lad any conservation survey. They run all the way from the absurd to the ridieulous.

WR. CARPENTER: Thoy sny frnnk exoressions are good for the soul. If that is, true, this centleman's soul is in pretty sood shape.

MR. JONES: Reforring to Mr. Gatny's speech, in which he emphnsized we are readir for term permits. I sather wo are ready to those we know are qualifiod. What will we do with the other fellows?

MR. CASPEIMER: I want to say in derense of Mr. Gatny. He is a new man and I fina the older men are more cautious. I rememter last year a ereat man of you nere not so cautious, but you hive found tint no matter which wing rou jump you kurt somcbody. The Ioner you are on the lonrds, the nore crirefully you vill move. The Department is ready to in whonever fou kive the vord.

1R. GATIY: Can't these boaris runt one min nermit for one venr, tho sane as they crant a license for one rear, and then tho other fellon who hias the dependent commensurate property -. they can wrant him a pormit for ten ycars? It will alsays be the same -.. there will be $n$ fer mor in ench district who can't qualify, but eive thom a nermit for one yenr. Thex ron enlimmaintely go to a bank and if you cni talk about a permit, thet is a wle lot grator thrn talkinf about a license $\rightarrow$ and it is ronter in the triting and transfor of livestock. 
Now, in our district, therc are a few men who aro not qualified at this time to qualify for a ten-year neriod. Give them a smaller permit. We can make mistakes and we can correct them. That harn is there going to be if we do give sorieoody a permit who doos not deserve it. We can take it awa from him later, but the actual bona fide livestock businessmen is entitled to ti:is stability of this permit.

MR. CARPIPER: Mr, Gatny suggests that we go immediately into issuing term pormits to some and not to others.

MR. T. B. MATHIS, ST. GNORGS, UTAL. (Arizona Grazine District No. 1): I would like to spcak as a bunicer and a board memicer. I think that the bankers are not nearly as badly worried over their lcans now as they were beiore any permits were issued -. pardon me, I mean liconses. I think they are more concerned that their patrons see they go into this carefully and get something thcy can depond on, then to mish into it. For my part we are willing to nove along pretty well as the Dopartment thinks best and if the date is here and the Departmont is roady to issuo permits to those who nre reedy and have tho information and data to gunrantee these permits, then it is all right with me.

MR. R. J. CCNWAY, CRAIG, COLORADO. (Colorado Grnzing District No. 6): I have been listening to these koys talk about permits and I have becn thinking and I rill say something if you will let mo. I don't believe you could issue a permit until you havo all the data'to work out the carrying caprcity. $70^{\prime}$ must mait to get this data. We admit, the data might not ve corrcet. All right then, dn it this way. Issue permits - term perrits - when we get this data, but confino it to three years and then we can pericct this data and then I say prohably wc would bo ready to issue ten-year or seven-yenr permits. Thy can't. it be done along this line.

MR. CARPENTER: TC now have thrce suggestions, one is the sugestion that Mr. Conway just madc thet we issue torm pormits for thrce venrs until we get the data perfectod and then issue ton-yenf permits. Mr. Wathis thinks we should go carefully and not issuc pormits until we are resdy to isine them on all the data ohtainable. Mr. Gatny thinks we should issue permits right away, and thon gather tho data. Some say three genrs, some say onc year, and some say issuc permits up to $75 \%$. Proonbly ench one of them would Iit sone particular part of the country and after this discusaion is given horo todey before the state meetings it will be of value for that purpose.

MR. P. W. SPAULDING, WYOMIING: Sitting in the kack of the room and looking at the number of men here, it seoms to mo that there is some knoviledgo amons our advisory board members of what the range really will carry. A knowledge, I believe, sufficient to issuc the permits, if and when those who are reing given intensive training in the C. C. C. comps, turn in the data. Then we can make a pro rata adjustment. But it seems to me there is some knowledge among the members of the Advisory Boards at this time to issue permits.

MR. C.ITPITIr: Yes, I agree with Mr. Spaulding, and I wish to say that the men from Now Moxico will probably vouch for it. When those range surveys are mado thoy will ic laid before the Board and they will te asked whether the Board thirks they are correct. They will bring in all they found in tho field and ask the Boards, are those correct. In general, there has been no disagreement, as Mr. Lee has said. I see Mro Brownfield $\cdots$

MR. A. D. BROMNFIELD, FLORIDA, NEN MEXICO. (Ner Mexico Grazing District No. 3): Mr. Carpenter, may I say -.

MR. CARPENTER: Mr. Brownfield. is chaimman in his district, and this is a man who has been throuch it all in this, if anvtody hes.

MR. BROMNIELD: Unzer the ljcenses grnited we have been concerned only with the lands they have customarily used. Now, comin out of tho licenso-ocriod to the permit period, or granting the aljotments, you are nore concerned with cstablishing tho lines -. the dividing ines betwaen the ranches. In our state we 
havo been told that some $90 \%$ of the ranehers have agreed upon these lines and for that reason wo say that we are ready for the permit. One year, throo yoars, or ten jenrs, wo are $90 \%$ ready for nermits. We, for the sake of aidine; the Division of Grazing and '3r. Carponter, nro askinéf for $75 \%$ and helding in reserve for their benefit and futuro devolopments this $25 \%$, and for that reason vie believe that eaeh and every one on advisory boards and our epportioned time for mnking the allotments and reeommerdations - then you will find it vory easy to make your recommondations for the term permits.

MR. CARPINTER: As our time is rolling on, I. want to introduco a new topic, beeauce me wish to eover all of these topies so there' will be some Eencril bnekground for oach state committoe to work on tomorrom morning and the national committees to work on tomorron aiternoon. Wo will tako up railroad and wizon road cheekerhoard lands.

This publie domain wasn't made in blocks, but when the Governmont gave grants to railroads, it was senttared out and a number of grants mado. The railroads were given alternato seetions bocause Coneriss did not mish to ereate any great interests. They gave every other seetion there beeause thoy rere supposod to sell it and dovelop little homes. Practically all of that eountry that eould bo sold or rented has been done so. Some has been used as nublie domain. It vill bo of interest to know that in the state, of Nevadn, where the lur gost amounts are thero, with the railroad hovine the most public lands, the Southern Paeific Land Company, I think has some four and one-half millien neres of land, part in Idaho and Utah, althourh this saille land takes in some land proferenee in Ner Mexieo, Arizome and Montana, and is a magon crant in Oreson. The most, however, is in Novada.

We met with the roprosentativos of tho Southern Pacific Iand Cormany and re agreed on a cooperative eoutrat to uso nino of the railroad eomany's orned lands and the Govornment lards tomether, and the apnlicent for thio lanis will meet and they rould arrec that if a man aid not have a pricrity or dopendont eommonsurate property, he rould not pet on the Goverrment lnnds in between. congress sars that those who hild the richt to uso tho Governnent lands should be able to use the rnilroad Innds in part. Now, I don't know whether that eontract has boen finally approved or not, but when it has been, it vill he followed by an order for the Reginnal. Grazier to vork out tho particular a.lotments. Thoro are, I believe, about 150 in ivevaria to bo worked out.

The method used in Idaho in working out isolated tracts is as follows: Thero were some 125 isolated tracts that could not be handled on a regilar rango operation. Our representntivo in Idaho went to the to:m near the tract and asired all the inhabitants to adjust their difficulties ard the were told if thes didn't, it would be dono for thom. Then rou set richt out on the land you have less diffieulty in settline matters. Tho rosult is that it wes worlred out in Idaho. There vore over a hundrod, praeticalis all vero fixed up with allotments, and no appeals. This is a mattor for this metines and other meotings to consider.

If there was noboly in Nevida, we could castly say, rell you take the south and we will take the north, or rou take the land north of the rillroad and we will take tho south. That would be just as finir for the railroad as for the Government, but with all those ranchos out thore, we ean't do that, and we have to go into a huddle and rorking this out on this traek. But we have a preeedent now.

Wo have authority in Seetion 9 and 70 are coing to start in working out part1cular allotments in Nevada. This acrecment was put up to two boirds in Novada, oven the terms drafted and reegived their amproval hy the Boards heforo it was takon out to Tashington and they considered the chesicerboard lands in Nevada, Idaho and Utah.

We have alroady rorked out a situntion similur to this in Distriet I in Utah a similar situntion, which was suceosstul. 
Wren we come to the state land, I feel like askin the pcopie irom Arizona and Ne" liexico to pardon me. State land is one thing up here and arother thine, down therc. In Utah four sections of overy twrnship wis siven to the school, and is part of their reliablo, substantial setuj. Here those four sections lio whero they vore mranted originally. Fundamentally, 90 f of them are not lcised in Utah. This is a serious situntion. To aro in nut tion with the State wond Board hero

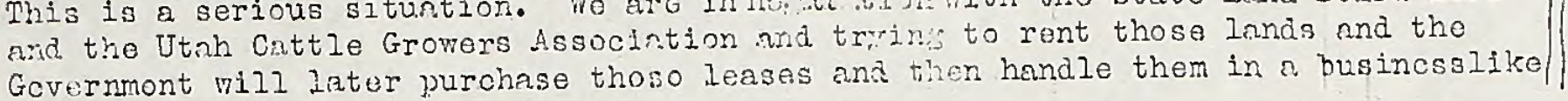
kind of way.

Te have the megon grant siturtion ir Oragon nnd wo have the state laws in ojegon and nil of tho northern states. I vant to duvose just a little time to tris to let you lmon mhat is beins done and I will nor cpen that tojic for any discusaIons or question you dosire.

Te have touchod on the subiect of licenses, the subject of permits, the subject of rance surveys, isolated tracts, railrond crd wason krants, state lands, and

cheolerboard lands. To have a number of athor tonj cs left.

I have an connouncement to mate that Utah District No. 3. will meet on the Roof Garden of the Hotel Utiah at 7:30 -- all users of the rrino in that district are invited to attend. On the Foof Garden of the Hotel Ut: : at $7: 30 \mathrm{n} . \mathrm{m}$.

I am going to leave the matter of foos and finaveos until last, becnuse when wo get on it, we don't vant to be cut off by any other irrelevant matters.

On the matter of stock drivowns there have bcen a larce rumber of entrances which havo beer abandonod nnd have reverted to nublic domiin larjs. In beneral, our rule has been to foilor: tre advice and suestion of the advisory board in such matters. And a lare nujber of stock dritrovers lierotofore ssteblishod and found not to be in accord with the uses, have been abandoned. Any queations on stockdrive'rays.

MR. WAYNT GLRDNER, ST. GDORGT, UTAH. (Utah Grazirg District No. 4): Tine exchange of privately ormed lnnds that conc over the drivewajs. In Wasinington last surumer, they authorized us to co nhond nnd wa those changes, if thero was somo form of assurance, sonet:ins voriced nut by tho Dnpartmon", the parties could ro to the indiviauals ano nssure thera thit, i:l diue tims, there rould be a decd or sonetions in tins $\mathrm{wy}$ of i tringier, then wo could go ahod and uso theso lands. In our particular ares, wo 30 for 60 miles or moro over 2 lot of private lands. lindo trados and exchanes tn mako possible that drivevay, but ro havon't any forms or nny lecal minter that we un go ahead and make exchnzas to tho satisfiction of privato land holders. Fint an wo do?

LF. CAREEMTIR: I sugcest that you got the cireular from tise land office, which covers land exchniges, and in that you will fird a form of application for an exchnice, tion ench jan rill hove to file his aplication for exchnnge. It will then be forwarke to the repertment and como bnck to the fonrd for rocommendation, and ticen be acted unon. The Genornl Iant office horo in the Federnl Builaing will hive those circulars for distribution.

MR. WHINiTR: Just one question, $\mathrm{M}_{\mathrm{r}}$. Crmonter, on thrt same line. In $a$ cose where a man is givon an allotment, and they hamon to have 640 acres thot is not in, and they went to miko cxolnare of.it, should wo follow the sarne procoduro there?

MR. CARPIITER: If rou expoct to chnno the titlo on it. Aro thore any other questions on stock drivereys or trails. In the matter of allotments, attention lins boon called to thi fnot that, severnl times during tho meetins, I havo mentioned a completod rnge survoJ. Thit is rmit a nano to nost of you. Mr. Holohon, who has charge of rnge surveys, informs me that he will put up a

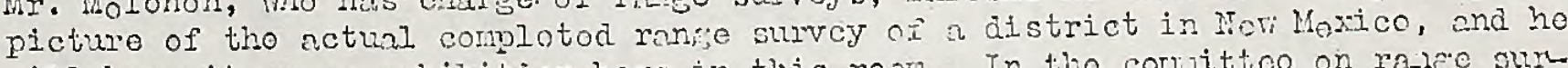
vill have it un nn exhibition lore in tlis roon. In tho conjittco on ralec am vos, he is soing to take thom ovw and siron then whet a conpleted rane surrey locks like, and Friday norning, and possibly Thunding ovouin, ho will hevo on display looro, cither on tho mozanino flnor or in this roon, the corplctod $100 \%$ mp of $n$ district. It will bo of groat interest to jou to soc that. 
Tho ouschtinl fontures of the mp are the sme; tlo enrying copreity of onch 40 cere trat ind the eormensurite rotines of nll private propertios nro sim, and it shows how tho allotelent is mio.. It my sot nll bo i:l ono bloek. It jivos you a very intorosting picture, and they will bo put up on tiso Board for $y$ our inspuction. Aro there any questions on tilis metter of allot::ents?

MR. ANDERSON, ULAH: Gontlomen, on tho question of niloestion or rame, to enll oursolvos tio stop-elitaron fro: Idaho and Uthis, in Tevada District iNo. 1. I think wo hrvo bont on the rest of youl to thent guostion. Wo havo alrondy rew coived an allotnent. First re objected to it. Fo nttompted to, and we thought wo would, provo thnt we had usod eonsidernble nore of the raige in our privato operations for yoars. The Advisory Bonrd bould like to get.rid of us, alid moyo I courdalt olnge thon so, nuelh. I thinle, haybo wo rould do tho snre, if wo had tho ono powor, but ro havonit. Now, thon, they nllot us about 40 pereont of the ranco t? of our shoop pon fro: othor districts sny, "Thor enit do that!" But tliey have done it. Wo can't frazo there. Whet nre vo soing; to do? That question looks to me like it is beine pronaturcly Inanled by soro districts. i took tho trouble

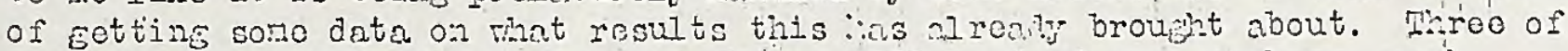
our men, operating about a band of sivocp, 2500 hond of orros porhaps, oneh, stayed back voluntarily and boucht hay.

Two of our men wero forced to star bnek by their finnncial bnekors. They would not risk their money on a band of shoep that would have to he fed with the other sheep on that small anount of land. Three of them wero foreod to liquidate. Twenty-tro of us are going to trckle it. Wo think that such premature action on the allocation of the rnnero should be stoppod, the bonrd acivisod us to appeal. All risht, ther vill do that, but an appeal is slow. We eannot winter there. We have nevor confinod our operrtions to a snall aren." Mo think thoy should Eo more earefully, I thank you.

MR. CARPEITER: I an Elad in the matter of ellotnents, that if they are step-ehilaren, they have sueh an able ndvoeate.

WR. R. J. . CONAAY, CRAIG, COLORLDO. (Colorndo Grozing District Ho. 6): Mr. Aiderson, if you got your allotment, the other fellow $\rightarrow$ would that cut down on his riehts?

MR. AIDERSON: They did not inve us an equal break. We do not want to bo set asido.

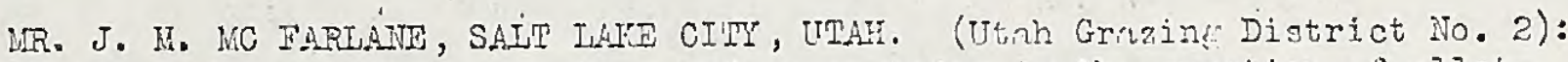
I trink the most important. qu:stion keforo us tocke is the question of allotments and we have hnd more eomlaints eame in from noole who are pin foes and reecivine nothinf. Now, the feel if ther are eoin to jet any fruits of any sort, some part of the rnne must be set out so ther will know that they are goine to have. I don't eare whethor you eall it a lieense or a permit - just so they have some range.

The cattlo men are willine to par for what thor get, but thoy rant to bo sure they pet it. But they won't eet it until we fix the allotmonts. In distriet 2 we have allotments, but no onforcement and I don't believe an rineo survey is complote until you have mande the allotments and tried them out. Tho allotnents represent the preetical part and if wo are foilg to do anythine rith the Taylor Bill we shorld have allotments and have thom right arary. (Applause)

MR. CARPEITRE: It is plain all tho cortors are applauding on that.

MR. MOBOII A. SMITH, S.IIT IAIB CITI, UTAY.' (Utah Gragins District lTo. 8): I don't understand hor you can alke an illotmont arranoment unloss it is very short and very temporary. Ther almars hive to get tho snme mun to moke tho investisation. Up to tho presont time all the alvisury honrds tint I hnte had any eortaet rith, eome follom fi-ared that if he could at thoro first, he vis?li be fixed up. The other follow rouldn't got in. The boards hare ittempter to make allotment nithout notifving the othor liconsces emzins thore. Ard somo follow cet thoir allotments and the board has attomted to give them nllotments 
and they can make them, but can they enforce them? I think that is out of order. Tho boards are workine toe fast; when they make these allotments without substantial 1nvestlgation. Every license should have a modifying order. That is important to each and every 11censeo on the distr1ct. And we must have a betior setup in order to make then work.

MR. S. C. HYATT, FYATTVIILE, WIOMING. (Wyominf: Grazing D1strict No. 1): In fleurins out the pro rate rango as uoed,as a comensurate radius, I thinl a yoar lease vould be about rlght. Hew Fill we go on a term allotment on a yoar basis?

12. CAIPEITIER: I don't: oe hor a term pernit can be haeed on a less number of yoars than the torm permit. If the base 1e transferred a part of the pernit would follow with $1 t$.

The question of enforcement wae brousht up by $\mathrm{Mr}$. Mac Farlane. Last jear wo worked it with a ranse rlder. That led to 10,jal difflculties. Our kickest prohlem. is the interetate movenent betwoen November lst and December 15th, and this year the four etates were divided into feur rceitons. Special enforcemont officials were appointed and elven a rlght to h1re hclpers in the program. I would like to hear from you gruzlng men on your onforcement this fall. Any susfestions about it or comments on it?

MR. ELMTR KING, TEASDAJE, UTAH. (Utah Grezing District No. 5): on these allotments - I have been on two boards and se have tried to make these allotments and the carryine copicity of the rances has a lot to do rith these allotments. One rance has had quite a lot of rninfall and will carry trice the number of stock one year it rould anothor ycar: The next yenr, if it doesn't get any storm, it mi,ht carry only one bend of sheep, whero this ycar with plenty of storm it will carry two or three bands. So which year would you use in figurine the carryling capacity? It pould be a mighty hard question to decide.

MR. CAHPENIER: Mr. King has called attention to the neeessity of undorstandine what the ellmate $\$ 111$ be in the future. It 1 e pretty hard to do.

MR. R. C. ATKIN, ST. GEORGH, UTAH. (Arizona Grnzing District INo. 1): On the strip we rere limitod to a fivemilo radius around water. Is tho Intcrior Department boing to make first use of ono nivd second use of nnother?

MR. CARPIHTER: Yes, I heard the question, and I have heard it bofore and it is golng to be settled, $\mathrm{Hr}$. Atkin, but it cin't be aettled in a day and how many men would it take to keep the cattle off tho shecr allotments?

IR. ATKIN: If they would givo us bome extra preferences, but to tie us down and make us stay in one placo is not fair.

MR. CARPENTER: A compromiso whs worked out in ene district with an area allotment for sheep along eome water and tro ce.tle drifted in and there was trouble with shoep poople. We didn't have fonces and wire and money enouch to fence 1t, so tho cattle people a, recd to ive the shoepman twerity porcent more allotment, provided they wouldn't kick, and lot the cattle drift. Did that work out satisfactory?

- VOICls. It has. On the samo situation, this intlemen fad a similar situation and we allowed flve sections betroen the sheopinen "e and the cattlenen's allotinents.

MR. C.ARPEIVTER: I thint, Mr. Atkin, that wo can work this alons similar lines, Givine a larger ellotment te the shoep intereat ond in order to take care of the drift that eanlt be prevented at this time. And that is what our boards arc for, gentlomen, at this time. 


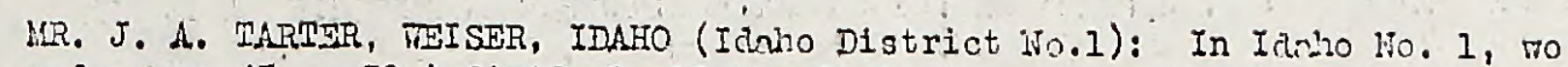
have Encio somo 45 or 50 indivicunl nllotisonts in tho clockerbonrd lnni. Got tlio fcllows to go rijht out on tho land and ranclo so::0 45 or 50 privato allotricats on tho clocl:orbond land, nnd I con't bollovo thoro has been $n$ silylo nincal on thoso allotionts. In a very casos, whoro tho folloms couldin't agroo on the allotneats, tho Bonrd handlod it for tho:.

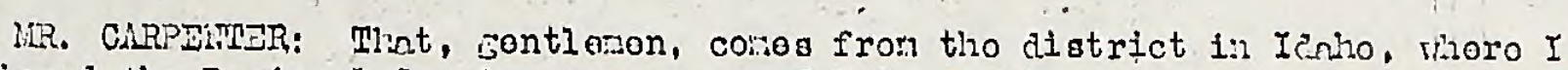
montionod tho ReGional Grazior ros succossful in porkins out individuni allotuonts in ricich wo havo had no aporls, and Mr. Tnrter is just olvins us ovidcico to substintinto rhat was statod lor. I n: vory Glad to $:$ on fror hitu becauso I l:avo not han an opportunity to soo thoso this yonr, but I hnvo honrd nbout the thinl it is a bi $\vec{G}$ rinrk to tho credit of that Board and that Romional Grazior, the way thoy havo inndlod that siturtion.

MR. H. H. KEECTR, GUNISON, COLO. (Colorado District No. 3): I do not lemow what tho cxporionce of tho othors hns boon in tho matter of this onforconont, but wo in our aroa in Colorado 3, ondonvor to protoct so:no of tiso arallor usors of tho mico. Maiy of tho usorg rore honost in thoir ondonvor to c̈nthor the stocle, but a certrin percontajo, vow sull percontaso i. lico:asoos, but pirians a lnrer porcostai in livostock, absolutoly amd uttorly alsrogardod tiso fnct that thoir liconsos had oxplroa. I fool that jou cin anl:o nllotronts. I focl that jou cen carry your Toylor Grnzine Act complotoly timi, you cnn tniso up ovory sujjoct licro, and unloss you can onforco thon, our sot-up is contirely too lnio.

\section{MR. CARPEINISR: Mr. Roso is in chnro of your onforcenont, isn't ho?}

\section{MR. METKER: YOS.}

\section{MR. CARPEINTER; Has ho taken nNy steps to romody that oituation?}

MR. WEFER: Mr. Roso ins boon up tioro sovornl tizos, but, Jitl tho linitod personnel that Graid Junction has nparontl; han, to ;ot thon on the jos at tho ti.mo that we nood them, it seons alcost imosoinlo. Sorio of ti:e pooplo fool tho pennlt; unier tio Taylor Grazing Act is too sovoro. Thoy fcol that tho Bonrds jay bo a littlo slow in onforcing tho $\$ 500$ - I beliovo it is - ponalty of tiso Grazing Act. To had, as you rocosnizo, undor our lnic lan, under adjurlicnted lands, sono rocourso. As I undorstand fros our attorneys, wo now lanvo no rocourso. To krvo not boon ablo to cot noarly tio mork dono, and it is said thrt it is lack of porsonnol. If tint is tho sotmip, cen't mo ari $\rightarrow$ ovon thou th nepropriations aro lard to got - con't re add onough to proporly onforco this Act? Tho bic rall up thero ins talion tho feod fros tho itt tlo fellon, tho fellow whon I beliovo was to havo boon protoctod undor tho Tnylor Grazini; Act.

MR. CARPENTER: I a Glnd to honr of that 1.nstanco. I an sorry, of courso,

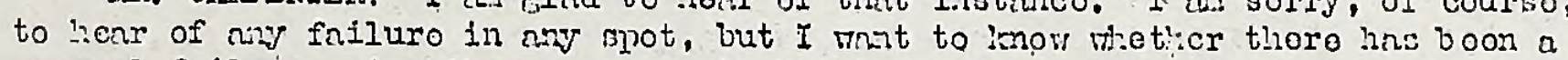
Eonornl fuiluro. $A_{r}$ thore noro spots lactine onforcciont? Iot's honr from it. To aro all horo towoticr and wo aro not afrad to faoe ti:on.

MR. PAULEY, UTAH: I would Iilso to asle the man who hns boen so succossful in their ollottacnts, if thoy have had a ranco survoy.

MR. TARTER: No, thoro has, not boon n ran;o surveJ, The zon who woro directly intorosted in tils fight nro.tho roulonal craziors. Ivory ins nround thore had an application for whatover richto ho thoulint ho had, and lo was notifiod of tho ti.jo and place of the mootine, and ho fi, urod lio hind $n$ right to appour, nni ho prosontod ins caso, nnd, in evory instinco, it rias tokon coro of.

\section{VIP. CARPINTER: Aro thoro any zoro complaints on lack of enforconont?}

VOICE: I can't soo any uso in vnlting for survoys if, in t:.o zost succossm ful allotrent, that ins not boon domo. Sorio of thoso districta won't invo ti:o

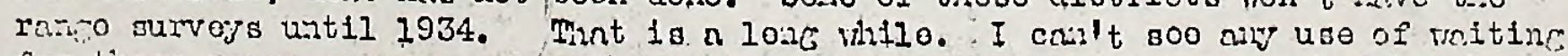
for ticso ralco survors, whon the nost ouccossful allotilont wo havo the has boon cotton up riltiout it. 
UR. J. A. FILCCXSON, DOBEQUE, COLO. (Colo. District INo.l): I mould Ii::o to sw a mord about Colorido No. $I$, in regerd to tho onforconont officors. Te lanto ind sono vory succcosful ton, I tiink, rorkina in our iistrict. A lot of tive Gicop nind attlo hnvo boun cut off by tho Bonrd nnd woro not allowod liconsos. T!ese now, n lot of the:s, had plannod to $; 0$ on the winter ranco ritlout $n$ license nis tilo tho rinttor up rith tio courts, and theso mon intercoded to s top ther:, and told tion that tiley roro not allomed on tho ranco, and they stopiped a froat anny of than, and it was much onsier to stop tiver fron coing on tho rango thin to ronove the wison thoy rero on. I think it hns scved a lot of liticiation, and causod poople that and no lieonso to tale a differout vion of 1 t, and I thi:ll: they havo dono a Bonderful work in Colorado No. 1.

IIR. TAINE GARDNER, ST. GBORGE, UTMF (Utal District No. 4): Just whon siould tho Dopartient of Invosticotion be callod in? I think no approcinto tio ren in the Dopartiont of Iivesticntion. Tiloy nre becinninï to soo the situntion. But I con't niprociate it won a Dopartiont of Invostiontion wain warts to count my herd witiout ny marnine fros tho Grazin; Dopartiont, whon I an notifiod that the Departiont of Invostication vants to count wy outfit. It socus that thoro should be at least warning fros tho Doparthort of Interior boforo tiro D.I. an comes out.

\section{WR. CAPPansiR: Fis hord countod out all ridit; I knor thint.}

WIR. GAPDIER: Tiy should i grouj of shoopwon, becruso so:se cattle rian makes a report, wix slould ther cone out and count us without so:so notico from tho Dapartiont. If the sheopson roportod to tho enttlo non, would it be frir, fitiout any miming at all, for tho D.I. non to coise and cisls tint tioy be dountod. The mea rito havo counted havo. boon contlomon in ovor, reapect. Th of havo boen vory consiclornte, but it oocis that tio D.I. nan, coning rithout niy warning at all, vithout any consideration of what it wis all noout, wa not npprociatod.

MR. CARPENTER: Our conernl rulo lo not to call on the D.I. until our orm enforcenent officors hinvo failed and po no tripe to got a report case to talee to court. In $00=0$ caoes, roporto rot in and tro invootirintions nro nade bind of "siort-cuttod", but it isn't, our intention to th that, nnd that is tho first complaint I linvo henrd of sucis a mattor.

liR. JOIN IEDLIN, HARPER, (RE. (Crocon District No.3): Thon 70 cot our sctup over thero, crlled District 3 , no cut it uip into sir. wits. Fo hnd our sotup there, and it ras cut up into six districts - w unito, rathor -- and the sheep mo: and the con ne: becon to trils about allotzents. Nr. Kloar:o is our Grazior ovor thero and he cave dorm and told uo it was our duty to oit dorm tocotior and tilk it over and divide it up. Th:o sheop :on nnil the cor acil had about tireo reotincs, and no divicod it up tiore. overy unit tint we had, in from throo to

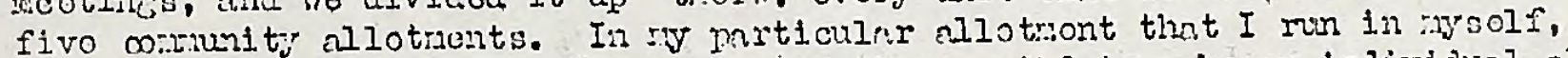
and ono othor alroepran, 10 askod thon if thoy mantod to malco an indiviturl nllotmont for tho s'oep and thoy said, "No, we mont to mu tocothor", and today me are satisficd; no havo our comeunity nlotwonto. Ous lince aro thero. $\pi_{0}$ don't pay mucl attontion to the linoe as far na the anttle aro esiromed, but ro aro run-ninc nore stock.

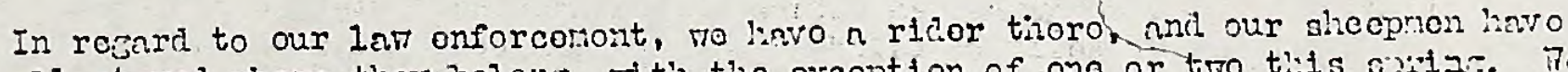
all stayod whero they jelom, wh the excoption of ono or tro ti: is sirin. . Te have a fer cattle men tint. ?nro a littlo irift out, but thoy nro tryin; to ait ther in as noar as thoy enn, and I eon't ti:inle se could have an better law enforcerient than wo havo sot. It sooms to 70 like, no fnr as these allotrents aro concornod, if tho sheep non all the cor son fill co hoso and sit dom arong thonsolvos, and figuro out what is richt for onch otiver, thoy don't. nood to cone to tho Dopartacnt of tho Interior to ask thon to allot it for thon. Thoy cais rllot it thonsolves. And thent is tho propor may to cet it allotted.

UR. CARPIITER; - I Wh that had boun a rndio broadenst, when ho snij that all tho sloop mon stayed whero thoy ahould. I rould lilko the world to havathonrd :in. Cn tho rattor of Improvoments, by tho mo, wo lavon't honrd wuoh from crom ̈on, but vo wero wlad to honr thrt kind of roport. Do you ronlize thero ins boon several :illion dollare spont on theso ramos in tho lnot for yours? To hevo 
just movod dorm to were we are using a certain part of the foos for rnice irr provencents. So $I$ all colng to open up the subjoct of foes and finnces in connection vitir rance improveronts. To will spond a little ti:e on ranijo irprovarionts and thon $\pi \theta$ will 60 into the subjeot of foes and financos and savo sono short tino for logislation.

of evorr dollor of Grazing foo that is ohnred, czcopt on indian lanis, concress has saic tliat 50 cents of it shall bo roturnod to the stretes, to be used as the state louislature any diroct, for the benofit of the countics. So::e statos, thru their state Iorislatures.- notably Nevada and Crejon - have said that it slould be returnod to the district ndvisory hoards, to be used for ranco betterment. Sono stntos, such as Califormia, sny, that that 50 coints should be used for monc bettcriont or prodatory amianl control. So:10 statos hnto said, as $\mathrm{V}$ orm stato of Colorado, thet tiut 50 conts shall co, half of it, to tho general school fund, and the county comisioner cris sny whore tio other holf gocs.

Then we cone to lçislation, it is coime to ve an interostin alter, and you iill lave an interosting roport frou your national coil.:ittoo. In tlio statc of Utih, wo ficurea up, just the other day, and tilat 50 conts arounts to 90 thousand dollors this yoar, so it is a considorablo sur, and lts disjosition is a anttcr of interast to overy stock ina, $\mathrm{O}_{\mathrm{x}} \mathrm{r}$ future, deponds on tho disposition of that noney. 25 conts of that dollnr is to bo usod by t:o Departiont for ran:o 1rprovorants and thelr maintennco, and, following our usual custow, when it is to bo used by the Secrotary of the fiterlor, the sucicstion will first cono from the advisory bonrd.

Mavy of the boards have taken tinelr 25 poroont; which fies returmod to nany of these districts, and havo usod it. to purchase materinl, and the C.C.C. canps have furni sicd the labor for tho oroction of the irprovemont. I I that nanner, not hnvinc: to use their noney for tho lavor, tiey linve mdo it go farthor in anterial. Are thore nny questions on inprovenents, or the uso of this money?

WR. P. J. BRATIAIN, PAISLEY, ORE. (Orogon District Yo. 2): I na very nuch interosted in improveronts. I sort of feel like the follow wiso vrites n lettor and always adds, nfter tho lottcr, "Plonso oxcuse tiro spollinï", when I zot up bofore an audionco and try to say sorectiln,. But I will try to oxplain to you vhat is Joticering n:e. As I sald bofore, I want to tal'e about ir:provorionts. I caise iero to talk about improvoients on tho rango. I thinle, porhaps, at tho presont tiro, thero 1 s nothinis concernine ay fellow livestock operators in our. crazine unit and district tha.t is moro inportant than the irpprovor:ont of tivo rance. In ordor to brine out the point that I sant to 1rply, and to point out to the Division of Grazing vhat wo nro up asoinst, I ne coin to describe our situntion thore as it stands.

To have had $n$ zoeting and havo dividod the range botroon. the differcnt/clnsscs of livestock, as wo wishcd to co it. To have taken in torritory whore wo run in comion aith tho shoop and the cettle, and wo also invo n cattle cllotnont allottci of $r$, and a spring rniso is nnothor part of tise country. In ordor to create circumstances that aro favorable, vie rust build 36 nilos of fonce. He also just build around 20 vater?oles in that crnzinis unit. Now, thon, in ordor to do that, re neod labor or we noed finances of so::0 sort. As ncrily no I cain firuro it out, we rust have around seven thounand dollnrs to build 36 silies of feace nni 20 wateriolos. Our Eront problers 1s: vicro is this ronow coning from, and where is tizo labor conine from. Perlanps $\$ 3,000$ or better of this $\$ 7,000$ is oxpendod, or vould bo expended, for inbor.

Wnv, then, re aro also told tint we nust do sorsothinc in tho ratter of concostion of our livostock on thent ran;o. To must either coinjote our plan or cut 40 por cent. Proiably a little insty but I npprceinto that remark. That reark has spurred us to do so:lot:ling in order to croato finvorable corilitious. Getting right dow to facts, wo need the CCC caps, wilich we do not hovo at tho prescint timo, or re noed sono annor of fluanclng. To dont nsle for approprintion necessarily, altio thet rould be ncceptrible. If the Governa:ent wes nblo to finance it i. tho snio nannor. I was abio to zet $\$ 5,000$ from an individual reccntly - borror it and croato $n$ sinikins fund. Thy not?. It was nccoptablo and asrocoble with all 
of us rithin that crazing unit, to do that. Mo could pay it all bncle witiin fivo or six jenrs. It was pointed out thint porhaps that rould not bo dosirihlo. Now,

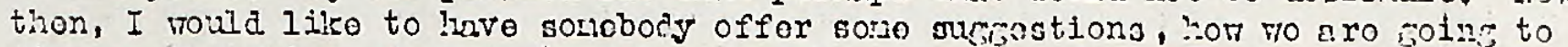
finaice thet zind of project. No doubt thoro aro wany otler units horo that aro nooding CCC carps, and noro of tison.

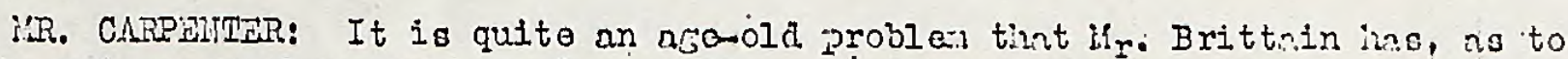
low to jot sonoy whon you havon't got it, end witlout nppropriations. I rij.I say in answor to your question, you $\mathrm{cm}$ recomend tho use of 25 percent of your foos that aro paid in that district, n:d you hnve, unger jour creor la\%, tho retpr:? of 50 porcont of the fees, wisich you cnn uso for improvements, and, furticr than tizet, wo have no roans, unless wo havo availnble sore of thoso ororconcy CCC crips to uso. Nor, are thore any othor quostions or augestions on irprovencats?

IR. MCGPTTY, NEVADA: To have the idee over in liovada, tiat t?:o indivinun].

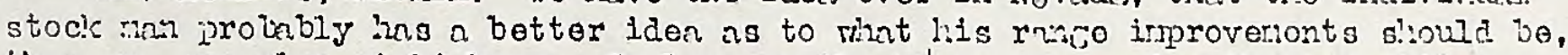
tinn cry ono olso aicht linve. So lon as tino :ing was coning thru taxition on all of tho taxpajors of tho intion, oxpenditure tira the OCC capss rot rith favor. But I ow inclinod to thi:k that, if tioy start sponilinis tise stoclaon's zoney, thoy would rather have it spont unaer sone othor setmp. It soens to wo it sight bo possiblo to ollor the individurl stockion to rako the improvonents on tieir ranjos as they soo fit, if noćossary, and thet ti:oy nijht apily tho grazine foos to t?o publio domain.

MR. CARPUITER: Tho CCC carps are not uainc any stoclunn's roney at all. T!a 25 por cent to bo used is, for instance, if you rant to put a rator tain: in on tho ranjo, you cm recoumend tint jour 25 porcent go into the purchaso of that tink, a:ad thon, rithout any further contribution from jou, the CCC labor cas put it in aid it is sot charfod acainst t?:o stod son at all. I ars glnd jou rnisod thint point, bocnuse I ment to cloar tint up.

MR. MCGSTIY: Aren't ro appronclint, tho point pinaro wo nro likoly to havo to finance those carps, if this continuos?

WR. CARPMITER: That rouj.d bo in tho futuro, and certainly wo would not want to so into that nethod of naklins inproveuents at our orm exponse,

MR. J. M. SMITH, CONTRAJ, ARIZ. (Arizona District No. 4): I ris!: to refer tc tho Ierislative sattor of tho 50 porcent. You hnve juet cot ar addod tax on the cattlo ian and livostock man of your stato, culd I think that this bory of $=$ en oucht to $\mathrm{g} 0$ on rocord in the legislativo corrittoe, frvorin; tint this 50 porcont of tho fees rovort to the boarda, the advisory bonses. If the want to raiso additional tares for t::o conoral school fund, thon wo aro in favor of thc livostock

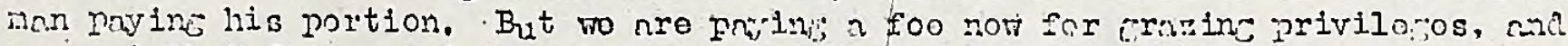
wo want that foo, nud in ay aind I think it is vor vital thet this ontiro nssorbly io on record, boforo'this propran is ovor, that we favor this 50 porcont coincs back to tho navisory bonrds for the uso and inprovonchts of tho rancos, accortine to tho recormenations of the advisory bon.

MR. CARPSNTER: The national lecislativo comittoc will be asled to dxnt up some fore of the nodel lar to be turned over to tho stockion, as inclivicuals, to place befole theix stato lefinlaturos, and tho mattor vill lave to be thrmsl:od out in tho ton strte loilslaturos. I seo ono stato logislator fron Uta: stending up. Mr. untiis fron Colorndo.

WR. MATHIS, COLORADO: In COIorndo, Whoro you hnve soturnod 50 percont of tilis to tho comiseionor, or 25 , has thoro beon nny othor adjustront arado in the county tares?

MR. CARPENTTER: No.

MR. MATHIS: Then it is an additional tax to the cattlornon?

MR. OARPENTER: YOs, 


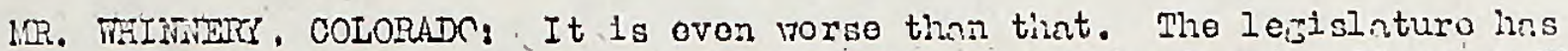
jut 25 percont in the cenernl sciool fund and thon fono aload nnd said it s'all be proportionod nccorilin to tho census in tilo school district. It is prncticnly

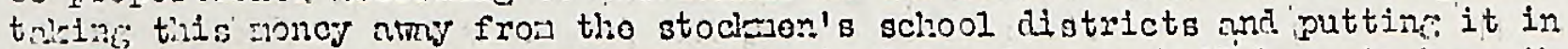
ti:o innas of the tom. I beliove thint, in Colorado, mo shall havo to havo that lo -isl-tion airended, and I no stronly in faror of vhat tho contlowan has just said hore, tizat us pooplo from Colorndo should ask it bo roturnod for tho uso and

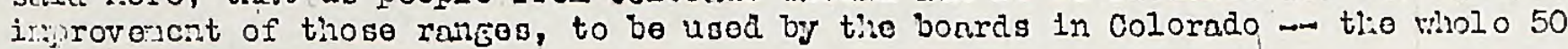
percont, if jou ploaso.

MR. CARPJNTER: I don't beliove ne, nood further nrements to convince all

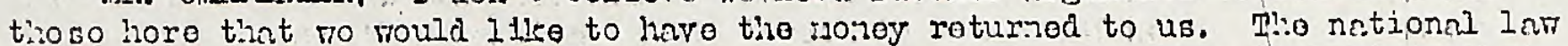
sajs it s'inll bo exponded ns ti:o stato lecislators diroct... I don't bolieve t!:at can bo c'anc; oc, but jour s tato locislators, I boliovo you vill find that tl:oy vill toiso it up.

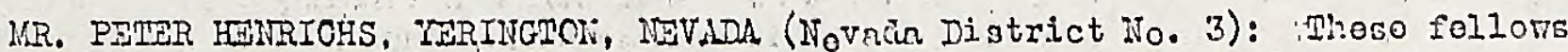
wore slow on the dran, thoy nore.asleop at tho switch, rion that thing wont ovor. Tinis lar said it ras to go to tho Tronsury. thon it ros to bo rotumod, and the wen at t?:o hoad of t?:o stock zon in tho stato of Novadn oot busy and fot that tumod ovor to the advisory boards to uso as thoy sarifit. Tho ouostion is/vory oroni, anything portalining to tho jood of tilo rano.

MR. CLRPEITTER: Nevada 20.3 lod tho may - Movada and Orogon - - and Mr. Henric!ng is tolling you so.

MR. HENRICHS: I havo cot an a:ondsont to add to it that will help us a little bit :aro whon 1 t cots thru.

MR. CARPINTSR: Wo havo ono tomic onIy, laft soro, and then is the natter of foes and finnicos, and, bofore wo trico up fecs, I will miro a strtement on, financos. Wi:en tho Division of Grozinc wa oricimelly crentol in January of 1935 , thero had boon no appropriation : 1ndo for it, tho apipropintion jour runing from July 1 to JuIy $I$, so it wns noccsenry for ther: to just borrow non by assienment from otior divisions and jureaus of the Dopnttiont of the Interior, such as the Division of Investijations nid Gchorel Iand Office, and Golorical survoy. The only now person put on tizo payroll wos rysols, and I and to bo paid out of the secrot'rn's cortingent fund. That was tiro condition until july 1935.

Thon consress passod an aproprintion of $\$ 400,000$, and a liuncire tiousand dollars. of that ras earmarked for tho expo:ıscs al parlns of tio District Advisors. Ti:at left a surs of $\$ 300,000$ for tiro prjacnt of tire Division ancl thelr tra\%ol ma sunCIry expenses. Cut of that $\$ 300,000$, wo non :ave 45 men in tisc fiold, spread out over the ten states. You lenow, tirore is nbout one or tro to a rejion. Ther are sproad protty tiin. A fer of t':on aro putting in thoin tine supervising tho ram;o suivoy. Some of tlon put in thoir timo on onforcenent, atliers zeat ritli zou on tho boards and io over tioso aiplichtions. Tiero has boen plonty to do.

I feol that, if thoro is nny division of the goverisont that l:as workod this yoar

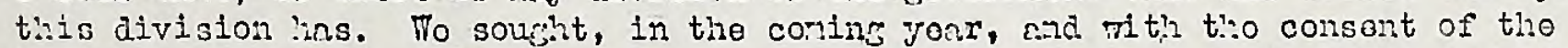
Dopartident, to inve an incrensed apropriation, larioly to spood up thoso rancc survcys, and ro asked for an increase to $\$ 800,000$, villch vould, 70 thouglut, ariply taice care of 1 t. That was cut hom by tiro airoctor of ti:e Budzot to $\$ 550,0 \mathrm{w}$, hich is the s'upo in rilich it vill go bcforo Congross, and Congross is standins and rilotting up a enifo on thoir boot, cotting reniy for us. I don't mow hor it will coso out. If it coes thru, a larco part of it will fo for ranro survers.

To all vint tho budïot balancod. To nll want oxponsos cut coim. But, when it coics to our orm particular activity, wo bogin to soo tho noed for nore nonoy. Tic aro goins to hive to triko $1 t$, along inth tito rost of tise country, and wo are

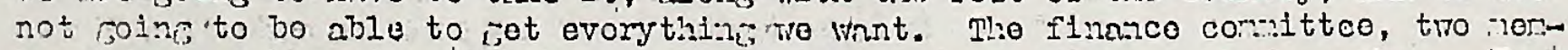
bcrs fros oach state, rill lieve all tho facts of nur finances boforo then. $7 e$ vill have vory littlo, if nny, increase in our approprintions next roar. ono hunàred thousana roos to tilo Bourds, the otlecr tirrco fourths to the perianont sct-ur. Next joar, wo :opo thore rill bo an increase in it. That is tho situr tion, as to our finances, and I Whsil to sä ti:is _- and I believe rou vill ap- 
provo of this wer of doing: Thoro ras so:zo sentincht thet ro should ovorppend

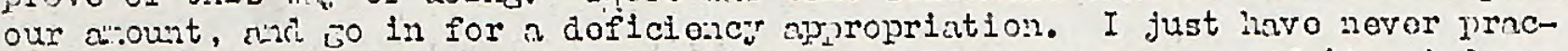
ticod $y$ ow businoss timt ray, and I just could novor npyrovo of it. Aul wo aro onc division that lans a littlo so:lothi:a; loft over at the end of tho yonr. 70 -..ny jo suljoct to criticiss for not coing as ruch, but ro rill hovo sor:cting loft over at tiso ond of tho joar.

Co:inin to tho subjoct of foos, jou will romowor, lnst jons, foos voro sot nt fivo conts por hond por rant? for cattlo and ono cont per hond jor ::onth for s'loep. Mhat feo has boon for all of tho ton states, vithout niv difforencos. In tho past yenr, thoy havo his a bal droutl: in onstor:a Montain. Tho enstern.

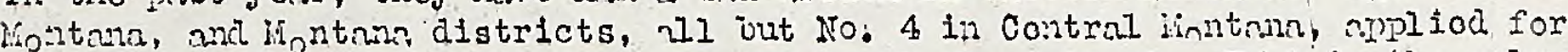
a roveto of ti:o foos, Wilc: nas urauted by tire Dopnrtiont. That is tho only rem bate tint lias boen appliod for, and that ins boon molo tis yoar, with tho e excention of an application rintcis on:o fron ifovada. inost of tho foos in irovada aro hold up bj litication, a rostrainin; orior koopin; the Doparttont fron colloctlike tho foes, so tho foos thoro :avo bo: $n$ paid into court nile rill bo hold

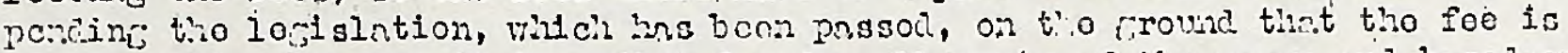
umonsonnolo, bocauso it is a flat foe for oll ports of tho rinse and basclo on t:o fret thit thore is 10 authority to isguc no feo undor liconsos, wish cono unicer section 2. Mint is, of courso, for t':c courts to sn.

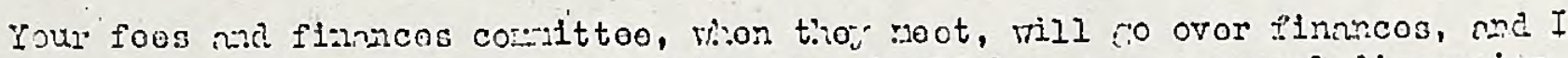
fenl, beforo it is thkel up by stntos, we siould hnve sono jororn aiscussion

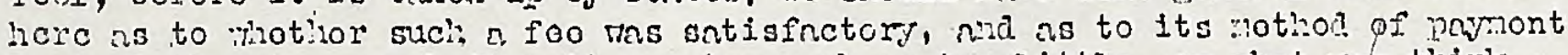
by instillments, or vict?or it was too acli or to littlo, or rikat jou thinls sbout it. So no will open tio subjoct of focs.

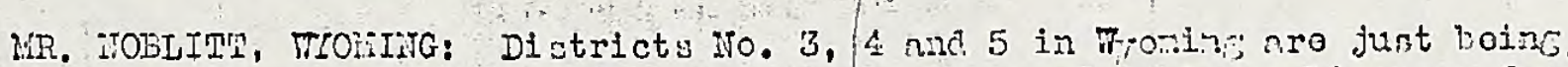
completer, as I uniorstud it. Plans cro to bo jropnrod to issun liconsos for

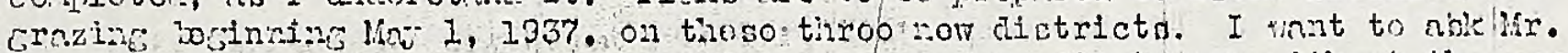
cripentor if wo vill not bo nortittod to opalnto our first joar vitiout the paymont of any foos. That ig, the first wonr usser licenso, 12 nontho from tho finest of noxt liay.

MR. CARPENTER: That is the mothod, Mr. Woblitt, that was followed in all other dictricts. Tho first yoar of oporation no foe was charced. Fill these new districts have one yoar with no fees? I' would like to hear the sentiment of these district advisors in this mnttor. I have novor had the quostion raised boforo.

MR. E. L: JAMESON, KINGMAN, KRIZONA. (Arizonn Grazinc District No. 2); March 1936 was our first boginning and the first dn of July 1936 mo paid up to Janunry 1, 1937. If thore is such a rulo as that 78 have rever henrd of it. I have to say no member of our district hns made any particular protest of any feo, and mo feel wo havo our money's morth in the wey of protection.

MR. CARPENTER; Mr. Noblitt, could jou henr Mr. Jameson?

MR. NOBLITT: Howover, up in Wromine we wero under tho imprcssion that it has been tho practice of chrreinis no foo for the first yenr under licenso. of course, we would like to haro that extended to us.

MR, J. V. TAYLOR, CARRIZOZO, NEii VIXICC, (NoV Mexics Grazing District No. 4): I would like to know if the gentloman did not hnve tho use of the grnss this Jenr when tho rost of thom mero payinE; for nothing:

MR. CARPEIITER, Mr. Noblitt, this is kind of $n$ tough crowd.

MR. NOBLIMT: To hnve all been having the grass and wo nro all rilline to, pay for it whon wo have an organization and know what wo aro doing, 
MR. D. F. HUDSON, IANDER, WYOMING. (Wyoming Grazing Nistrict No. 2): It his been senerally understood. In our part of the state that 70 mould have the use of the rnice rithout paving the foes the first yoar after the dist::ict mas setup. All the stockmon in our district have mot us halfmny in regard to the feeding of grass and wo have had vory little grass or water thore and in the future if 70 have to pay for this ralle and have no more grass than we have now, the thing is certid nly a fatlure..

\section{IVR. CARPENTER: A very frank expression from Mr. Hudson:}

MR. ED MALAFFEY, GRAND VALLEY, COLORADO. (Colorado GrazinE District No. 3): The centlemen have the advantage of our experimental stage that the other states have come throuch. Then we pere Eoing into that exporimental stage ve did, not chargo a fee. It is no experiment with you mon. in Froming. You are Eetting the advantage of the experimental stage that wo have gone through, and you also have tho advantaso of the Erass the lnst fer years. And along that lino, from what I sam of the big fat cattle from wromine, you must have hod better Erass than we had, too.. (Applause)

MR. HUDSON: The cattle and sheop come out of other districts into ours. In District No. 2 in Wyonins they have como out of District 1 . We don't know what to do with them. That is where our srass went. If fat cattle came from thoy didn't come from District No. 2 .

MR. CARPEITER: There are no fat cattle when we talk about feos, we all agree to that.

MR. F. C. VAUGHN, BAKER, OREGON, (Oregon Graziné District No. 6): To wore orcanized in November 7,1935 , and we paid our 1936 dues and assessments in our district.

MR. CARPENTER: Orgnnized November, 1935 , and patd 1936 dues. No furthor argument than that.

MR. D. H. ADANS, IAYTON, UTAH, (Utah Grazing District No. 1): District No. 1, Utah, was orfanized and ve made our orns mules and regulations. The other twenty-five or twenty-aix districts did. not tell Jistrict 1 what to do. I don't believe it is the proper thing for the other districts to telf the advisory. board of Tyoming what to do with their profits. I thin: it is entirely out of place for the advisory boards to say whother Wyomine is guilty or not guilty. That is a question betreen Tromine and the Department. (Applause)

MR. CARPENTER: Mr. Adams susested it is out of placo, but he tells thom anyway.

MR. MC ARTHUR: I wanted to ask if that state isn't part of the United States Government and to say that my tenant and $I$ have an arreement and are flad to pay those fees. Br those fees we are toking care of the range, and we spend part of the foos taking care of the range. Wo are willing to double the present fees if it. would get the grass back.

MR. CARPENTER; I am listoning for applause on that. (Applause) Leaving then the question of these nen districts, let us open -

VOICE: I noted that in his statement in regard to those fees, his tenant is paying them, not he, himself..

MR. JOHN MC MURRAY, OAKCEY, IDAHO. (Idaho, GrazINE District No, 2): In our district we expect the first year. to operate without any fees. To offer no apolosy for it and if necessary we will give reasons why, 
MR. CLRPEIVTAR: Another one of the new districts, and he joing with the new districts from Hyoming. Are thero any questions or discussion on tho division of foes?

IIR. J. PERKINS, OVERTON, NEVADh. (Novada Grazing District No. 5): Thy is it the fees should so to the state lesislatures and not to the maintenance of the ranso itself? Tho object of tho Grazing Act is to perpetuato and improve the ran;o and I think it would be no more than fair that soventy-five percent of those fees should go back into the rango for 1 ts improroment and that would Eivo any stockman a break for his monoy.

MR. CARPEINTER: The roasor, Mr. Perkins, is that Concress said that half tho fees should 50 to tho Strto lesialaturos diroct. In Novada the state lceiglature has dirocted that back to you. So that you people in Nevada there already have sevontrifite porcent. The other states neod to do most of tho squallins.

MR. JOHN DAVENPORT. (Nen Mexico Grazine; Dintrict lovo. 2-a): We have a new district and we do not think we should pay any foos. If we pay those foos, do ve set any extra service?

MR. CARPENTHR: They wish to join with the other new districts and then he asks: "If we pay theso feos, do ne get 'any oxtra service?" Does ho get any additional ernss for the fee? No, sir, tho conditions will be the samc.

MR. RAVEIPORT: I meant protection.

IR. CARPEITIR: Neither additional grass, water or protection. You will Eet the samo service.

WR. GEORGI GOSE. (Nen Merico Grazing District lio 2-b): Wo are a now district and we are all villins to pay. (Applause)

MR. HYATr: Last yoar in Fyoming 1 ve paid for it. To, paid our foes, most of then, and I Will say wo aro miphty thankful for tio Taylor Act and for tho protection we recoived and tho little foo that we paid has been repaid many times.' (Applause)

MR. CARPENTER: That is quite a statement from Myoning, if ycu wore hore last year. What about fees for 1937. Iverybody seems to want to rnise them.

IR. G. M. TIERNEY, CEDARVIIIE, CALIFORNIA. (Nevada Grazing District No. 2); All of the new Erazine districts should pey a fee, then wo can hold the fees down. Te wore all supposed to pay a feo last year. We came in in November and paid for last ycar. What is, the matter with these new districts in rot wantirg to pay a foo?

INR. COMAY: I Would like to ask if in 1937 the present grazing iocs will be the sario. And if they can't poy them, we might d.o a littlo better. Wo might increase them. And I more -

MR: CARPIENTER:

Te are not interested in wotions at this time... This is a General discussion to asaist. in the state diacussions tomorrow. The Committee on feos and finarices will brine in a resolution as to applicability to new districts.

MR. O'NEILL of WOMING: I don't understand how anybody could make a motion to increaso the prico on this, poceuse no sheep or cattlo men have mado any money in the last fivo years. I know it couldn't be done in the last two yenrs to make any money with jour livestock.

MR. CARPEINER: Mr. O'joill has only left the sort men and the horse mon to support the national. Government. 
MR. FRAMK MEANS, SAGUACHE;' COLORADO, (Colorario Grailing District No. 3): I sincerely hope that the feos for 1937 vill not be raised. Te are in a prodicament in Colorado. We were too slow on the trigiter and the county commissioners and school found got argy with all the moncy and we would like to have an opportunity to ask our legislature to got the funds diverted to the proper place, and if we now increase them, and the Colorndo legislature, which is as freedy as any, Eets a hold of an incrcased $f \theta \theta$, well, that would servo as anothor sourco of revonue, and I think we also ought to get it back. I recollect in looking over my papors of my file in 1906, whon we jaid $\$ 0.10$ per head threo entire seasons on a cor. It got up to $\$ 1,00$ a head in that camo district and I will state this, if we are goins to increase these fees, the first thine wo know we will have the fces in this organization comparable to the fees char ocd by the Forest Sarvice -alvays on the increase and never on the decrenso without a great deal of argument and trouble. No, I don't think wo should Incresse fees until we seo wherc we are.

MR. BAITARD, I would like to ask at this time if tho Department contemplatcs a raise in the fees?

MR. CARPENTAR: Tho Dcpartmont has taken no stand on that position. They are vaiting for a recommendation from this body of men bofore thoy tako any action.

MR. GSDDES of NEVADA: Nevada is already in tho urfortunate position of havine asked too much, but wo foel that wo have a loritimate basis for nsline that the fees in Nevnda be not set at the same rato as thoso.set in the bettcr grozine frcas of somo othor states. It takes tiro yonrs to raise ono lamb and twolvc nounds of wool in our state. We foel that we nave a legitimate argument and that these fces should bo sot by stritos, rather timn by the country as $n$ wholo.

MR. CARPENTIR: Mr. Goddos thirks tint these feer should not bc uniformly levicd, but should take into consilorntion the character of the ranges.

MR. SMITH of ARIZOINA Rolative to tho grazing faes, most of the states up state hrve not made this whole $50 \%$. Your edvisory roards micht not get it. Lct us, beforo we even consider tho raising of nry $f e \beta$, lot us iso back to our logislatures and get this put back in the adrisory bonrd, ond then when wo find out that there is at leost more tham $25 \%$ comins vick to us and $25 \%$ to the Department of the Interior, and thon we can talk about the raising of fees, but not now.

MR. WIGHT of NEVADA: That steps have beon taiken by the Dopartment to fix or determine if the proposed 1937 grazing feo is reasonoble?

MR. CiRPENTER; No particular steps havo bcen made, Mr. Fright, in that respect rit all. It has just keen left hore to be alscussed nind the rccommendation that camo last yoar was rogarded as a reasonable recommendation of a reasonablo fee.

MR. WRIGHT: What steps have becn taken by the Dopartment to determine whether this feo is reasonable to apply. uniforrily to oach area within tho same state?

MR. CARPENDSR: As to the foes; no one in the Department has crer considered they were anvthing but rensonable. Thet metter has never beon ciscussed or brousht up. But $7 e$ welcome discussion and I am sure that any point of view will bo eivon every considoration by the Departicnt.

MR. WRIGHT: Then and where did you $f i x$ and determine whether this feo should bc mado?

MR. CAPPENTER: The Dopartment considers it was made out here in/Srlt Lake, here last yoar.

Mi. WRIGHT: No one back in Mashington fixed that? 
KiR. CAFPEINTER: No, no one at all. Wo Erazing back in Tashington. They, th never think about it. hero?

MR. MC MURRAY of IDAHO: I understand that the foo was set by the stocknen

\section{IR. CARPENTHR: YOS.}

MR. MC MURRAY: I have asked them a number of timos and they have told mo it was fixod by $\mathrm{Mr}$. Carpenter or the Secretary of tho Interior.

MR. CAPPENTER, FolI, if you had been here last year you would have known how it started.

MR. MO MURRAY: I an talking about cutting it until no rot proper adjustmont. (Applause) Then the recoipts come in for the aistricts - there is anotier chance for a tax. I think we ousht to anpeal to our Congross to amend the Taylor Bill to soe if we can't get this money baek from the legislature. You must re more presperous than us in Idaho until we eot proper distribution of funds.

MR. KING: I bolieve this experimortal otase of the Erazing departinent could be very detrimental due to the condition of the livestoek at the present timo and the Department men are not getting much benefit from the grazing lands. Until the lands are distributed and they have some grnss te sell, I objeot to a raise in fees. At this time I realize we are not getting any grass for the money.

MR. CARPENITE: You would want to be the judge of the grass, wouldn't you, Mr. King?

\section{MR. KIIT: I would leave that up to the stockmen.}

MR. STAES: The only thing I have to say on the fees is not to increase the fees - that is, not to raise thom. Do not raise them for the benefit of the livestock business. In all the states where you ret all this money baek to the livestock men, that is geing to be for the benefit of the stockmen. If you raise the fees by the state as a whole, but if we can't for the benefit of all, we want to graze to improve the conditions of the livestock business. We don't want to have the fees increased at this time.

MR. CAPPENIER: Do I state it right when I sRy, united we stand againgt a ratse in foos?

IMR. P. J. BRATMAIN, PAISLEY, CREGON. (Oregon Grazing Districti No. 2): In Iistening to these arguments here and the quostion has boen raisod gevoral times about the dispoeition of this grazine fee that takes the circlo arciund to the state legislatupe, around to the county and finally back to the advisory board. I can't see why wo can't take a ohort cut hore. Why can't our advisory boards and stockmen prevail upon our congresemen to enact a law or amend thist law so that seventy-five percent of our fee goes direct to the advisory loard for disposition on the range and the remining twenty-fivo percent to tho Government. Fo pay a tax on our livestock and we also pay a tax on our real estate - why the different tax?

MR, CAPPENTER: Gentlemon, it is a little past fivo now. Tomorrow morning at 9:00 you will assemble by state committeos. If you do not know the room, you can ask at the information desk. We would like to have all state comittees assemble at 9:00. All district advisors aro urged to come to that meeting and each itate committeo will moet until noon. After they have diseussed these subjests they will elect tro memers of the national committee on erch of the six big topics and thon those men vill moot at $2: 00$ in this building at rooms designatod. Then Friday, the asserbly will moot ngain in this room at 9:00 and the committoos will make renorts and will bo discussed on the floor and voted on. Wo ono Will speak or vote Friday oxcept district advisors without the unanimous consent of the houso. At that time the voto $7 i 11$ be takon and if 

requested, an Individunl poll $\mathbf{1} 11$ be takon by districts, by the dolegates voting from the districts.

MR. PETER HEIRICHS, YERINGTON, HEVADA. (Novada Grazing District lio. 3): Ant of these poovle that are interested in thet levada lam about tho transferring of the money, I 7111 bo glad to rake them a copy.

MR. CAPPEITER: We have coplod that law and 1 it is on the program.

MR. HENRICHS: Thank you.

(The moeting was adfourned at $5: 15 \mathrm{p.m.}$ )

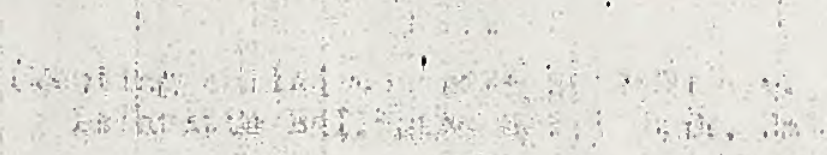


Salt Inire City, Utah

December 9,10 and 11,1936

\section{THIRD DAY}

Morninf Session

(Meeting called to order at 9:00 a.m., Jecember 1l, 1936, in the Lafarette Ballroom, Hotel Utah, Salt Inke City, Utah).

MR. CARPENTER: Gentlomen, if rou will find gour sents wo mill open tho mecting. The order of business this morring; will be to hear the reports of the national comittees, and as ro call tho committees, ask tho. chairmen of tho committees to oome formard and I wish he would leave a copy of the resolutions in front of the desk on the platform here.

We vill considor the readines as a motion for adovtion and then the matter vill bc thrown apon for discussion by the advisors only." The vote will he takon by voice and in case of division in tho vote, any delesate or advisor present dskine to have the assembly polled, we vill take the poll ns follows: Beginnin alphabetically with Arizonn, we vill coll each district, and the chatrman of that district, if he is present, or someone else delegated by him to be the spokesman, will announoe how the four votes 60. If only one man is present he will vote the four rotcs, If more than four men are present, each will take his fractional vote.

New Mexico has roquasted to vote their six districts altogether on all topics, so with the consent of the assombly, tho chairmar of the Nen Mexico delczation will simly sive the twentw-four (24) votes from Ner: Moxico.

Arc there any questions as to the procedure bofore we call for the renorts? If not, I will ask the chairman of the Committeo on Licenses, if he mill come forvird and loave a comy of the rosolutions on the desk. If you will please come forinard and read vour resolutions to us, Yes, I see the chairman hero. ur. Williams, if you rill come forrard as Chairmnn of the Committee on Iicenses, Have you an extra copy of your resolutions you can lenve on the desk'?

MR. F. D, WIULIAKS, MINERSVILIE, UMAH. (Utah Grazinr District No. 3): Gentlemen, I haven't had time to overlook our report, which nas submitted yestorday by the committoo on liconses. Wo had some considerable discussicm within our meetine, and me did not arrive at all of the idoas unanimously, rovertheless ve are coine to present to' you those ideas that ve did finally conform to and leave it up for your considoration.

Motion madc $b_{y} \cdot \mathrm{Mr}$. Hay of Tyomink; and seconded by $\rightarrow$ the name is not mentioned that: It he resolved by the National Committce on Iicenses that the determination of the priority rulo be left. to the Advisory Boards of each district of the sovoral states. (Applause)

I want to make a brief statement there, centlemen, that we mere so far anart upon the problem of priority that we could not eet together on the priority beriod, therefore, we decided to leave. it up to the different states to settle their om priority. Te felt that the different statos had so many oplnions and conditions to rork upon that wo finally deolded the diffcrent states should settle thoir onn priority rule. 
Motion made by Mr. Hyatt of iyomine and secondeit by Mr. Adams of Utah, that, ths National Committee favor a Dapartment policy in is suln time as the soveral Adrisor Boaras frel that thoy kavo reasonable knowlodse on which to is sue permits, Carried urnnimously.

Motion made by $\mathrm{Mr}$. Dland of Colorado and seconded y $\mathrm{Mr}$. Seeley of Utah, Resolvad by the National Conmittas on Ilcenses that the "Pronosed Naw Interpretetion of Preferonces undar. The Taylor Act" be acceptad in issuing, 11 censss in 1937.

Carried unanimously.

Non, we have cne or tro motions that wore mako hore that were defeated. If ycu would like to hear them. I. rill read them to you. If not, I rill just. submit tho motions and rosolutions to our. Director and jnes them as thy wero siven. That is your pleasure in that rasdid? (Audionce signifiod that thay did not wish to har the dafsated motions). Mr. Chairman, I movo the adopiton of tha Cormitteo report.

MR. CARPENTER: Thanik you, Mr. Tilliams... Is it jour plasurs to take theso up. soparately and djscuss then or tako the ronort as a wholo?

VOICE: I movo that ro tales thom lip separately.

VOICE: I second the motion,

MR. CARPENTER: The motion is mado snd seconasd that those resolutions from the National Committoo cn Iicenses be token un soparately and cliscussed and. I take it you mean to have them voted on senarately. Any diócussion on that motion. Aro you roady for tha guestion? (Calls for qusstion).

All those in favor of the motion that the resclutions of the National Commitee on Licenses be taken up, discussed and voted on anjarately, all those in favor sigrify by say ing avo. Gontrery - no. Tho ayss havo $\$$ t. Accprdingly, I rill read the first part of tha rasolution. .

The first resolution is ne follows. "Tint is og resulved by the National Commites on Iicensas that the determination of tho prioridy rulo be left to the Advisory voards of each district of the scvent states". Is there any discussion on that?

MR. J. I. INIDLSCN, FOUNTAIM GREEN, UTAH. (Utah Grazing District No. 2): I an not in favor of that. I thinic $7 e$ illl have too mucin discrepancy - r runnine from six montis tic ten ysars. Mr. Willians stated that tha conditions are so different. I do not think thare can be any different in tho netter of prior. ity in anj district. I think the Dopartment snould havg set that in tha be jinning. HCW could their have besn any aifference in priority.

I am opposed to ths resolutiun. I bellevg vo should get somerhere together. To should set a minimum and a maxinum to come $i x$ between those too lines. I am opposod to tha rasolution.

IR. AITEX FINDLLY, KALLB, UTAH. (Arizone Grazing District Na. 1): Is a substituta motion in order?

IR. GAPPENTER: Yes, sir, that is nlways Jroper.

MR. FINDIAY: Gentlomen of ths oonvontion, I more that tha priority had in all districts bo Juns 2\%, 1954. .

MR. CARPEITTER: A mot:oil that a substitute resolition be offored in which the prioritr date be set at Jure $28 \mathrm{th}$, ( 1 presime you mean June e8tin, instord of June 27 th, as that ras tho date of tho passago of tine Tayior Act), has been mado. Do I haar a sscond to that motion?

second it.

MR. EDGAR RRAY, REDVAIE, COLORANO: (COlorado GrozinE District No. 4): I 
MR. CAPPENTER: Is thore any discussion on that substitute motion?

MR. BRAY: I am as much interested ns anybody in havine a long priurity, but the iden is thie. This Tailor Bill io a nationnl law and tho prioritios to my mind are going to havo to be tho same in all the districts. That is, if tho lay is to stand up in the court.

Now, as to the time of the priority. Anvkody knows, that will stop to think, that the than on tho range when that Trylor Bill was nassed has a priority. Here is what I would like to see. I tinink Frank heans brought it out yesterday in the Colorado delegation. The older your prinrity the better your right. (Applnuse) If you had been there ten years, you are absolutely ostublished and they can't kick you out. Hovever, if you wero on the ground when that Taylor Bill was passod you have some rights, but the man on there one year does not have the right, that the man on there two or threc or four vears has.

But, if we are to avoid litiention, let us make a rule that will hold water. If our rules aro soins to stand up in court, let us make them risht. It is absolutely ridiculous for one state to have ono yonr and another state next to it has ten years. Let us have, the older the priority the better. Let us have the date the bill mas passed as the priorit- date.

MR. J. M. SMIMH, CENTRLI, ARIZONA. (Arizona Grazing District No. 4): I rise to a point of ordor. To have a notion beforo the house that ve adopt the recommendition of the committee. The latter motion has not been voted down. The first motion is still before the house, Anend it, but I don't think you can substitute it.

MR. CARPENTER: The point is well taken; If the man that offered the first motion cares to amend it ..

MR. FINDIAY: I understand, Mr. Carpentor, that jou ruled -.

MR. CARPENTER: I have reversed my ruling and it will have to bo offered as an amendmont and diecussed before the amendmont is voted on, $28,1934$.

IRR. FINDIAY: I move to anend tho priority dato to be considored as June

MR. CARPENTER: Insteed of puttine it in a motion, the amendment is propor and boforo the houso. Any discussion on the amendment? Aro rou ready for the question? The question you are now voting on is, whothor the resolutions that the Resolution Committeo mado; that the priority date should be left to the separate district boards of the states, or whother tho amendment, which is that it should not bo left to the states, but set as tho dete of tho prssage of tho Act " in all districts in the ten vestern states, should be accepted.

MR. i. ii. BROTN, OGDEN, URAH. (Novada Grazins District No. 1): I make a motion that we poll by individual rotes instoal of by districts.

MR. CARPENTER: Mr. Bromn has made a point of order, that ve vote by person instead of districts. I qish to sar that 70 do not have a list of tho delogates nere. Each district vill poll. Te do not have a complete iist of all the olem gates and I could not poll by individuale. Also, in my opening remarks I stated that wo would poll by districts at tho request of an one individuel.

The Chair will mile that motion out of order for that renson. The question is to amend tho originnl motion and make a uniform rule of priority. All those in fevor of the motion, signify by sa-int Ave. Those opposed - No. The No's have it. The amondment is not carried.

We now continue the discussion of tho nriginal motion. The original motion was: "That it be resolved by tho National Comittoo on Licenses that tho determination of the priority rule bo left to the Adyisnry Boards of ench alstrict of tho several states". All those in favor sienify by sn;ing Ave: Contrary - No. The Aves have it. The motion is carrien. 
The second resclution is as follows: That the Naticnal Comiftee favor a Department policy in issuing licenses until such a time as the several Advisory Boarie fool. that they have reasonable knovleago on which to issue permits". Io I hoar any discussion on that point? Are you ready for the quostion? All those in favol of the socond resolution, which is: "Thet the National Committee favor a Departmont policy in issuing licenses until such a.time as the severnl Advisory Boaris foel thit they have reasonable knowledge on which to issue licenses" - -

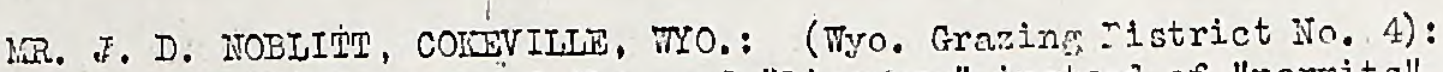
Mr. Chairmin, I think you used the word "licenses" instead of "pernits".

MR. CARPZNTWR: I will read It again then, Mir. Noulitt. "What the National Comittoe faror a Department policy in issuine liconses until such a time as the several Advisoly Boards feol that they have reasonablo knoriledge on which to issuo perrits."

\section{liLR. NOBLIII: That is correct.}

MR. CARPANTER: Are you ready for tho question? All those in favor of the resolution, sienify by saring Ayo. Thoso opposed, No. The Ares have it. The mom tion is carried.

The third resolution is as follows: "Rosolved by the Hational Comittee on Licenses that the 'Proposed Now Intorpretation of Preferoncos under The Trylor Act' be accoptod in issuing 1 icenses in 1937."

I will road that again: "Resolved by the National Comittee on licenscs that the 'Pronosed. New Interpretation of Frcforonccs under the Tarlor Act be accepted in issuing liconses in 1937." IJ! al scmeone on that comilttee what the "Proposed Now $I_{n}$ terpretation' is, because tinis rofors to a proposed now intorpretation.

LR. WILLIAMS: Uir. Gairinan, some of the rules that the Department got off rogarding priority.

MR. CARPENTSR: I will read thoso Nor Interprotations for you. "The proposed chances in the Grazing Regrlations to carry tinese provisions into effect are to substitute the following for Pago 2 of the RuJjes of Ma $\mathrm{h}, 1936$, to wit: $\rightarrow$

"A qualifiod applicant will be consicerod in a preforred classificntion if ho is a mombor of any one of the followine four classos:

(1) Landownors ongergod in tho livestoch busincss.

(2) Bona fido occumnts.

(3) Bona fide sottlors.

(4) Owors of water of water pients.

"The following definitions will assist in determining who belongs in seid classos:

"A landowmer must bo in "tho livostock businoss" and not simply "an omer of livostock. An occupant tn be bona fido must shor that ho actually occupies land to the exclusion of others for at least the porind for which such land is subject to graztng. Such exclusive occupetion may be by foncing or ctherwise excluding trespassers. Posting notices uinccompinesd by acturil yossession, or part time seascnal use by arazing livostock, will not be cousidorod occupancy. Any land clnined to bo occupicd must bo neld under a right such as to ontitle the applicant to possession. Iand.s to winich the applicant has no lawful right of occupation caniot be rade tho basis of $n$ claim of bona fido occupation. (The last sentenco above may also bo statod as follows: Occipancy of lands to which there is no lam ful right canrot be bon fide.)

"A bonn fiac settler is one who maintains acturl rosidence undor lnwful authority on the land to the exclusion of a rosilemee olsowhere. An omer of water of water rimits must show that it is for stock vntor purposes and hold under proper nuthority from the state. Qualified preferred applicants will bo given liconses to grazo the available public rango insofar as necossary to give a proper use to the lands, wator or wator rights omed, occupied or leased $y$ them.

"In dotcraining what such proper uso is, tho following dofinitions will guide: 
"Property - shall consiat of Innd and 1ts jroducts or stock vator ormod or controllod and used according to locnl eustom in itvostock oporations. Such property ig:

(a) Dependent if public rnige is roquired to mintain its propor use.

(b) Moar if it is close onough to bo used in connoction with public range in usual and customery livestock oporeticns. In caso tho public rango is inadoqurte for ell tho now proportios, then thoso which aro nearost in distance and accessibility to tho public range shnll be given proforonce over those not so nonr.

(c) Comnensurate for a liconse for a cortain numbor of livestock if such property provides proper protoction according to local custom for said livostock during the perfod for rintch tho public range is inadequnte.

"Qualified applicants tho besidos being preferrcd, as nbovo sot forth, nlso havo grazing priviloges recognized and acknowledgod shall havo sucil priviloges safeguardod by being givon considerntion bofore such applicnits who do not hayo/such grazing privilogos,

"Grazing privileges rocognized and acknowledgod shall bo callod priority of use, which is defined as follows:

"Priority of use - is such use of tho public rango before Junc 29, 1934, as the Secrotary of the Interior, or his administrative officers, by refercnce to local. custcms, statutes, decisions of the courts, $a$ other compotent sources of cvidence, may find to havo boen recogrized and acinowledged as a propor use of both tine pubIic range and tho lands or vator used in connoction thorevith.

"Issuanco of licensos - after rosidents vithin or imodiatoly adjacent to a grazing distriet having dopcndent comonsurate property are provided with rongo for not to excoed ton (10) head of wolk or nilch stock kopt for domostic purposes, the following namod classes, in tho ordor nanod, will be considored for licensos:

1. Qualifiod applicants of tho preforrod class who also havo priority of uso, to an extont not to exceed such priority of uso or comonsurate rating.

2. Qunlified applicants of tho proferrod class nho do not havo priority of use, to an oxtont not to excosd thoir comsonsurato rating.

3. Qualifiod applicants who aro not in the proferred class."

I vill say, in gonorat explanation, gentlomon, this is simply a clarification of tho Pules of Marcin 2. It doos not amount to a vory matorial chance of tho Fules of March 2. I bclieve the coinitteo fiavo some thought and study and considoration to that. Is that corroct, Mr. Williams?

MR. WIIIAMS: Yos, sir, we wont 0 ror each and ovory one of thoso probloms and discussod thom pro and con and finally arrivod at the resolutions nrosontcd. 
MR. WHINNERY, GUNMISON, GOLORADO. (ColorRdo Grnzing District No. 3): I world like to nsk if they carefully checked the water right question. It scoms to me that there ans a little difforerce thore in readin: that rosolution than therc vas before. It is one of the vital thines we are prrticularly irterested in in Colorado.

WR. CARPEITER: I will read the definition of property again then, Mr. Whinnory. "Proporty shall consist of land and its products or stock vater orncd or controllod and usod nocording te locnl custom in livestock operations." That is practically the same.

MR. WINNERY: That seoms to be tho same. quostion?

MR. C.LRPENIER: Yes, sir. Any further questions? Aro you rondy for tho

VR. FILIISUS: In discussine that we had a fceling;, somc of us, that re had bctter accept the dofinition.rather than debate it asid "ball" it up moro. We surcost that in the future those rulas should not bo sent out to tho advisory bonrds prior to thoir adoption at tho meetin: here.

MR. CARPENTER: In an oxtondod clarification of rules lile that, that was not really a rule, but a clarificntion of the Rulcs of Minch 2 . I way sar that this clarification of rules was porkod out vory cnrofully by a Committee, then submitted to tho Dopartmont and then agin taken up by tho Committee.

MR. J. E. JENSEN, MORONI, URiH. (Utah Grozin; District No: 2): I would like to have the definition of a man in the lirostocle business and one who orns livestock.

WR. CARPENTER: He rants to know the acfinition of $\mathrm{a}$ man in the livestock businoss and one who owns, Iivestock a man tho owns ox: com or sheop is the ovmer of livestock and it is possiblo to sny ho is in the livestock business to a cortain extent for such a smill anount. But, nlthours the amount may bo very small, if he denonds upon the incone clerivod from that stock ho is then - he is in the livestock business. It is concoivable that a man rith one corr could be in the livestock business. It is distinction vithout being a difference.

MR. FINDIAY: I mould like to knom, Mr. Corpenter, hom under your definition water could be commensurnte - - under your dofinition of commensurabflity?

MR. CLRPENTER: The definition of conmensurnbility is:" "It such property (that would be land or water) providos propor protection accordine to local custom for said livestock during the period for which the public ringe is inadequite."

III. FINDLAY: Under "C" $\mathrm{C}$ under propertv, is what I had referonco to.

MR. CARPENTER: "Property is commensurate for a licersc nccording to local custom for said livestock" - is that what you moant, Mr. Findlay? If you have water that will proviae protoction for livestock for the pcrind for which the public rangc is inadequate, then your proporty is commensurate. In the South that definition does not equally fit in with thoso conditions.

MR. FINDLAY; In that caso, Mr. Carpentor, how can you tivc the owner of water priority over the omer of land?

MR. CARPENTER: You cannot. The ormer of land and tho omner of 7.2ter sthnd tofether. In New Merico and Arizona if you do not have water, no matter what land holdings you have, you cannot got a license.

\section{MR. FINDLAY: In Arizona it all depends on water.}

MR. CARPENTSR: The undorstandinE on those southern ranges is that water is the primary factor. I believo that rule has been accented in Now Moxico nnd with somo qualifications in other places, whore tho food nrrangement does not ontor into the picture. 
MR. WHINERY: Another question on whter. Are thore any possibilities that if this rule goes through that our irrigation vater does not count?

NR. CARPENTER: No, the dofinition savs vater used in livestock operations. Watcr uscd for irrigation purposes, if used for livostock oporations rould bo considered as commonsurate, but if used only for pntering ficlds would not be considered. Do I make that plain? Such part of irrigntion vater as is divertcd and used for the support of livestock would be. considered water in the terms of this Act. Purchnse or rental of vater is considered as control. Is that correct of what has been done in New Mexico? That has been my understanding all along.

MR. WHINNERY: Doos that bring up stook ownor priority or the owner of tho water priority?

MR. CARPEITER: Range rights go mith vater, the sarie as they do with the lndi; Mr. Whinnery.

MR. GIIMER: I think for the sake of clearing those records as to votes, we should poll these votes.

MR. CARPEITER: The Chair statod that at the requast of any ono man, I rould poll the assembly. I mill accept the voioe vote otherrise.

MR. GILMER: You poll by nirss first?

MR. CARPENTER: Yes, I mill call for a voice voto first, and if it is ovorwhelming I vill declare tho motion carried. But aryone has a right to ask to have tho vote polled and it $\nabla i l l$ be polled imredintely by districts. Are you ready for the question? All thoso in favor say Aye - those contrary - No. The Aves have it. I belicvo those are all the motions of the committeo on licenses. Is that correct, Mr. Milliams?

I rill ask the Chairman of tho Committoe on Permits to como formard. Leave a copy on the desk. Othervisc, come forvard and rcad those resolutions.

UR.'A. D. BROWNFIEID, FLORIDA, NEW MEXICO. (Nen Hexico Grazing District No. 3): Friends, it looked like war might break out any minute. Wo finally settlcd down and emerged rithout any bruises. He considered first, and had a very able explanation brir. Kcrr, on the difference betreen licenses and permits. And the provision for licensos first under Section 2 and then permits under Section 3 of the Act. We discussod whether tho sotup nocessary in ordor to have tho qualifications of the permitte should be altercd, and we decided to leave that as it is. Then preforences - tho samo, that is moaning to say; the citizens and the state authorized corporations.

Third, the nemer clause, and that one a great many overlooked the McCarrcn amendment to the act, meaning that if the sotup is under mortgnge at the oxpiration of the license poriod, tho Governmont is to be held to issue a permit. And the duration of the permit may be from one yenr up to ten rears. Ten years is the maximum and that is left in the beginning to the Divisior of Grazing, whether in the beginning the permits will bc from one year, two, or more.

The permits and tho priority brought about the major part of the discussion and there seemed to po a great deal of uneasiness in the minds of those in our committoe and a grent deal seemed to interprot, oven though $\mathrm{Mr}$. Kerr gave us a very full explanation as to what would happen when we go on the permit system, that the word "priority" goes out of the picture. They thought if that happenod, we had better stay in the liconsc poriod.

Yct, we are making an effort to go forward and wo decided we wanted to got on permits as soon as possible. The vord "uso" in Section 3 of tho Act, whore grazing privilegos recognized and acknowlodred shall be adcquately snfeguarded, was construed to bo your protoction. Any ranch unit properly setup and going, their commensurate property

$202 \% 7: 4$ 
There mas a good denl of unensinoss then about property developed subscquent to the Act. Fould the individunl developing a bese land, developing his whtcr, get a right.. Tho comittes decided that that piace of property could not be interpreted as commensurate.

Then thore was another arrangement enterod into and that was the so-collod homesteaders. Are the mon viho bought a trx titlo to a pioce of land that had not, been opened for yoars, had not had any use, but at the time ner improvements placed in the way of more devoloment and water, could thot land gct a right and vould it be classed as commensurate proporty? The committoo felt that, if now, if I get off wrong - there was so much said, tinore ras so many talline scvoral times and we only came out rith one resolution - I may not got it quite right and if I do not, I gincerely hopo you $\$ 111$ correct me becausc I on tring to intorpret the meaning of phet I undorstood you meant and what ris not roducod to writing.

Then, to ect back to the subject. This piece of property that had had water developed on it prior to the Act and hod been used prior to the priority of uso dato. that was fixod in issuine licenses nould be rated as commensurate property and carried a richt.

Then, ve got down to the probler of the degree of dopendency of commensurate property and that is that I hnve just finished sayirg as to how to rate commensurate base property over enother. In allocatin public range to jndividuals, of usc of individuals to amend tho allotments and. I see no ray to clecido on that excent to leave it to the Advisory Boards, bccause thoy are the only onos who really know how your proporty and my property ranks in use and water doveloped and those othor ratings which are necossary to decide upon. Shall I read this resolution?

\section{MR. CARPENTER: Yes, sir.}

MR. BRONNEIELD: Now, we brought out only onc rasolution and in order to stabilize the industry, and me all felt that a yermit had more stability than $n$ license, particularly with, tho loan corporations and that a feliow could mortgago his entire sctup, and that is subject to all rights carried with proporty. The individual is left out when wo get on permits and aro dealing with the lands -. the commonsurate property only. So, no loave vou this rosolution:

RESOLVED that the Division of Grazing insuo term permits upon recommendation of the Advisory Board in the District affocted, which shall includo seventywivo percent of the allotmont rocommended for any ranch unit or rango setun in prom portion to commensurate property omned or controlled; that the trenty-five percent of tho allotment and numbors of livestock shall have a temporary license until such time as the Range Survey procram is completed.

MR. CARPEIYTSR: Would you please read this resolution acain, Mr, Bromfield?

MR. BROMNEIELD: "Resolved that tho Division of Grazins issue term permits upon recomendation of the Advisory Board in the Distrct affected, which shall include serenty-five percent of the allotment recommended for any ranch unit or rango setup in proportion to commensurate property owncd or controlled; that the twenty-fivo percent of tho allotmont and numbors of livestock shall have a temporary license until such time as the Rango Survey Probram is completed."

UR. JONES: I would. like to inquire then these permits are issued if they Will be at the discretion of the boards. Can the bonds use their discretion or vill they all have tio be issued?

\section{MR. CARPENTER: Tas it your intention that all bo considcred?}

MR. BROnNIEID: I think when a numbor of ranch units are in a position to go on a permit arrangement that thoy should be normitted to do so. 
1R. CARPENTER: Thether the surver had been comoletcd for tho entire aistrict or not. Seventr-five jercent term jermits can be issued on anj part of the district when they start in to is ane thom on recomendation of tho district board; Is that correct; Mr. Bromiticld?

MR. BROFNIFIELD: Yes.

MR. CARPEHTER: Is it jour pleasuro to roto on this resolution?

- VOICE; I make that motion.

VOICE: I second it.

MR. CARPENTER: The motion is mado and seconded that this resolution of the Committee on Permits: "Resolved that the Division of Grazing issue term permits uron recommendation of the Advisory Board in the District nffocted, / which shall include scventy-five percont of the allotment recommonded for any ranch unit or rance setup in proportion to comensurate property owned or controlled; that the twenty-five percent of the allotment and numbers of livestock shall have a temporary license until such time as the Rana Survoy program is comploted", ho ndortod os ro"k. . . . All those in favor say Ayo - contrary - No. The Ayes have it.

MR. FINDLAY: I rould like a vote on that by distriot.

WR. CARPENTER: Before pollinis by districts, I am going to read the resolution again. "FRSOLVED that the Division of Grazing issue term permits upon recommendation of the Advisory Board in tho District affected, which shall include seventy-five, percent of the allotment rocomnended for any ranch unit or ranee, in setup in pronortion to commensurate property owned or controlled; that the twenty-five percent of the allotment and numbers of livestock shall have a temporary license until such time as the Range Survey progrim is completed." Is that correct, Mr. Brownfield?

MR. BROWIEIEIN: Yes.

MR. S. J. TYATT, CRAIG, COLORADO, (Colorado Grazing District No. 6): HoT can you get down to a term permit basis before the criacity of the range has been determined. Too many pitfalls in that.

MR. J. M. FILSON, SAFFORD, ARIZONA. (Arizonz Crazing District No. 4): The last words, "the Range Survey program is comploted" do I understand that to mean if you have an allotment:under considoration. Fhat is a little vaguo.

MR. CARPENTER: Tho rang*e survey progrnn referred to is a complete checkup on all of the dependent proporties near the district, a completo sauge of tho carryine capacity of the public Jands within the district, a complete working out of whatevur allotments of lancis fourd advisnkle to mleo. You cannot set avay from this, that pormits and allotments nre semed into together.

MR. JONES: Until the ranere surver was completed, what kind of permits would be given?

MR. CARP ZNTER: Under this resolution it rould be up to seventy-five ncrcent of the allotment rocommended for any ranch setup.

NR. FINDIAY: It seems to me the resolution puts nuthority on the advisory boards so that if they felt that the allotments verc not comlete, so that the term permit will be grinted.

MR. JONES: I don't think you got me quite clenr. The question that I raised was the vay I urcor:tand it, that this soventy-five percent is to be permanent and the twenty-five percent tempornty to an $\mathrm{mnn}$ who has a permit issued to him. Not sevonty-five percent left over of the apnlicants, Is this 
board foing to he allored to issue perrits to one or two in that district and leave the others on a liconse system; or will they have to consider all tho applicants as permittees?

MR. WATT: I do not like that resolution. Every advisory board in this rcom knows thore are too many pitfalls ahead. Unless you get the capacity first. The Division of Grazing will be put in $n$ bad nosition. There vill be turmoil.

MR. D. H. HDAMS, IAYTON, UTAH. (Utah Grazing District No. 1): It seems " to mo that where you issur soventy-five percent of the stock allottcd to one man in one part of the district, boforc the range is completely survered, thit someone on the othor part of the district is not going to be issued a liconso. I think there are too many pitfalls, like the gentlcman from Colorado said. Tait until the general survey has heen mado. Adans?

MR. CARPENTEK: Do you rish to offer an amendment to this resolution, Mr.

MR. ADAMS: Yos, sir, that permits bo granted thom on the ratio of tho carrying capacity of the rango, when the ran; $; 0$ has been survovod.

MR. CARPENTER: The amendmont has been offered to this resolution to tho effect that, I will re-state it, that permits he only issuod after the ringc survers aro complcted.

MR. SDAMS: That is corroct.

NR. CARPENTRR: That is stnting it simply. IDo I hear a second?

MR. SWITH of AIIZONA: The motion.has crrried and announced by tho chairman as carried and the gentleman has as!ed a poll from tine house. I think the amendment is out of order until that motion is taken care of.

MR. WIMNERY: I think you ruled or tlint.

MR. CARPENTSR: Wo falled to carmy out the poll because tho discussion came on then. Bocs the maker of the motion for the poll want a discussion now or the poll.

MR. FINDLAY: The discussion is what I vant.

MR. SMITH of AIIZONA: If somo of the gertlcmen who voted for the motion want to make a motion to ro-consider the motion and the house wishos to reconsidor, then you can reropon it for the house. But you have declared the motion carried. This gentleman has asked for a poll. You said the motion was carried. Now, wo have got to have a poll or somobody who voted for the motion will havo to ask to have it re-oonsidored.

MR. CARPENTER: I Am EOing to ask for the discussion to consider and then we will vote over again. All those in favor sav Avo - contrary - No. Tho Aves havo it - the motion is carried. The motion is carried and re will vote later on the amendment to it.

MR. SMITH of ARIZONA: I have no desire to get technical here, but I think we should proceed orderly, and as a man who voted for the motion, I make a motion that ve move for re-consideration.

MR. IINDLAY: I maintain the motion was not carried, It was onlv carried conditionally. I make a motion for a poll and it is not carried until it is carried completely.

MR. CARPENTIR: I thought ro were going to learn range rights, but we are goine to learn parliamentary lew. 
MR. SMITH of ARIZENA: As you will find out, after the chair has ealled for a vete on a motion and that motion has been announced as carried, that eloses the motion. This gentlemen has asked for a poll of the house. There was no more detate on that and if the poll carrics tho motion again, there' is no way to reopen the question again.

MR. WYATT: In order to expenite matters, would it be in order to make a motion that this other motion to rescinded?

WR. CARPEMPER: I think we will stay atry from any more motions. Tho chair will rule that tho motion is not yet carriod until thic poll shows the motion lost or made, and all discussion rill pertain to the amendment and as soon as the discussion is over we will proceed on the amcndment. The amendment offored was that permits be not issued until tho rango surveys have been eompleted.

\section{MR. NOBLITT: Will the man please clarify that?}

WR. CARPEITER: I think you are elarified now. There is an amendmont up to the motion. The moticn was that seventy-five percent of the allotments be issued and trenty-fivo percert be held up. The arendment was that no permits be issued until range surveys be completed. That is what we are discussing. I have summarized it only.

IR. MAFHIS: I would like to talk on the amozdmont to the motion. The seventy-five percent was left entirely up to the advisory boards. I am in favor of the amendment to the motion. I think where you have a Class A license you have your permit in the bag. I don't think it is being to hurt your credit any to delay some on the permits. Why rcserve twerty-fire porcont when we can diseuss the hundred percent with the same information avaliable. We are already protected according to the bill, on any loans that we have boen hearing. talked of here. I don't think any finaneial institutions are vorrying at all if you have a Class A pernit or license; and they would rather :o would know our Erazing business and be sure we aro right whon ve issue tho permits, and when we have all the information available and noccssary data, ve will be in a position to nake it onc hundred percont. I am in favor of tho amendment to the motion.

MR. WATT: That comes from a bankcr. How good will a man's credit be.if after the capacity of tho range is determined he is eut down twenty-ivive percent. That rill not help his eredit. That will not give the banker the proper protection. The range survor has not made their report yet, but they will and they have asked the Division of Grazing to put on a larger force, and if this group will insist on it, there is no question but that the Division of Grazing will do it, and pusin this matter ahead as fast as possible. Like the gantleman from Arizona, I am with tho amendment.

MR. BALEARD: I believe that you can hear me here. Wc appointed our conmitteos and each statc has bcen represented. I bclievo I vill begin this like the lawyer does. "Your honor, please wo object." No appointed our eommittees on this and each statc was representod and I take it, you appointed the best men you had. If you didn't, you should have done, and I believeithis eommittee should be sustained and the resolution cassed as recomnended. If this amendment earries, I can see indefinite dolavs. Fe were told hero yesterday that the personnel to carry out this range sirvey was low, and that there was no imnediate prospect of getting this personnel augnented to any great extont. We are fighting against these dolays and if you please re resist the motion to amend. (Applause)

MR. TAYIOR of NEW STXICO; I ronder if this amendment would not place each district in this position. On a contested case it might hang in the courts for years, It inight stop the issunnce of permits in an erivire distriet. Tho resolution is lcft in your hands. Te heard here last year, ovorything ras tied in at tho discrotion of the local advisory boards. This resolution offored by the comrittee leaves it entirely at the discretion of the loeal boards, with all fedoral employees as members of that board. Ther are going to act fairly with the best interest of the entire district at henrt. I think ve should issue 
$\cdots-$

cormits to starilize our industry and got nme from those lieenses as fast as we can. I ani agninst tho amendment.

IR.C INER: I think permits should be issued as soon $n$ s the advisory borrds sec fit. Thor aro tho people who have the first hand information and the poople who have the ehance to got the first hand information. They havo access to taking ovidenco as to what $\approx$ man's qualifications are, ani no information is eomplete without that ovideree. A license io a temporary thing for it has no credit rnting. I don't seo how a credit man could eonsidor it very scriously in a erodit sctup. At Winnonncce, at a rocont conferenco, it came out that meny operators wore almost on the roeks beeausi they needod federal ald and credit, and could not get it until normits wore issuod. For that roason I nm in favor of making pormits as coon as possiblo and I think the ndvisory boards could handle that better than any other vey. (Applaueo)

MR. WOOD: I am in favor of issuing thoso permits neeording to the wishes of the advisory boarde of tho differont districts on the basis of the earrying capecity fixed by tho different boards until the survot is made. (Applauso)

MR. SMITH of ARIZONA: I rould Iike to call your attention to the report here in the progrn in the caso of Idaho, vhere it is estimated that the rnnge surver will bo completed in 1946. Nor you, gentlemen that have your range survers completed, now, do you rant to writ until 19.16 before you get a permit. Te boys navo had a lot of trouble rith the Forost in getting ten yenr permits and re are very mueh interest about the permits. Te mant to stabllize our livestock industry. Until you get a term pormit jou 7111 nover be strbilized. There is no question in my nind thet this entire group nonts to got permits and not wait ten years until a eomplcte surver is mndo, and if rou do got 1 t, the Department of Grazing does not have enough personnel and theso appropriations may not come in sufficient numbors to complote this nork. I think vo are ontirely protoeted by the resolution as adopted by the Rosolution Conmittee and I am in favor of the resolution and not tho amendment. (Applauso)

MR. CARPENIER: In ordor that thore mat bo no eonfusion, the issuance of permits in one district vill not bo delnod becauce the survey is not eompletod for tine issuance of permits in nnother district. Tho $i 2 a$ is so that there will be no deley until the survoy is completed rithin that distriet. That is tho question ct issue.

NR. IYATT: Thoro was submitted to this assombly by tho Liccnse Comitteo a resolution that when the advisor bnards felt that they had suffieient data to issue term pormits, they eould. Now, we all agree those districts will have to havo a range survey made. That way aro we leanins?

MR. GARDNER: They are Icaving us twentr-fivo pereent figuring that any board rorking over a poriod of vears will hnve an idea of how to make an estinate of the range. I am suro that re can. If wo ean't hit sorentr-five porcent of aecuracy after tro jears rork in this matter, I would be surprised.

MR. SAM ROSS, JORDAN VAILEY, OREGON. (Orogen Grezing District No. 4): I think that we have got to wait until those survoys are mede by tho Department, and thon passed up to tho advisory boards to pass on, that is too long. Why not havo the advisom boards mako theso survers and lot the Department pass on them. (Applause) Now, when they meko those surve.s re have got to approve of them. These advisory boards know their range and nobody is moro capablo of approximating tho range and surveying those ramges. Now, let the advisory boards nake these estimations and let the Department prove that we are wrong. I therefore stand for this resolution without any rriendments.

MR. JONES: I Fould liko to havo ir. Vhurhn make a statement.

- VR. VAUGHN: Gentlomen, this is a great opportunity. Oregon is in favor of licenses or pormits being issucd aftor a complete survoy of the commensurate proporty. Te do not feol that the advisory boards wor to take the responsin bility of guessing at a mar's commensurate property. Wo do not want to rait 
unt1l $\pi 0$ have a complete range survey rade, therefore the original resolution or the amendment theroto does not fit. We want the modium. Fe want tho permits issued up to seventy-five percent of the applicant's comiensurate proporty extent aftor that survoy has beon made by the Division of Grazing. I ronder if I have made that plain to you, that we want the permits after tho properti, is surveyod. Te do not rant to mait for the rangl gurveys. We fool that the advisory boards are competent to determine the carrying capneity of that range. That is all.

MR. CARPENTER: It may not be necessary to elaborate on what Mr. Vauphn said, boonuse ho made it very elear. Range survers are dividod into a chechup of carrying capacity and a rango survey of the range. '.lr. Vaughn wants a survey mado, but he does not vant to walt for the carrying capnetty of tho range.

MR. IEE: Mr.. Carpenter, I am opposod to the nmendmont and in fnvor of tho comittee report. I am surprised and disappointed to find that the minority of tho members of this convention distrusts thonselves ard their orm judement. I feel that they should not be so distrustful.

VOICE: Tre all feel verr dooply for Mr. Lee. It is going to be a very Iong timo botwo tho figuras and the ostinates.

MR. CARPENTER: I want to say this to everyone, under the amondment to the motion thore is nothine; that vili prevent New Nexico from considuring and issuing licenses - permits, within the very noar future.

MR. IEE: Me cortainiy appreclete the attitude of the Departmont.

MR. CARPENTER: That would be ineluded within the amendment. There is nothing in the amendmort that prevents going right into pernits. It is simply that no district shall consider permits until the ranse survey is completed.

MR. SIAES: How nre you going to do it without knowing the carring capneity of the range dorm thero, and at lcrst sevent;-five porcent. And then after you set that in my district, the whole canacity was exhausted by soventy-f1ve percont." What are you going to de with tho other twonty-fivo percent. Will you kill them. (Applause) The hoard would havo to know, would have to have evidence of cach Individual's capaclty and of our commensurate property. Then therc vould be no delny.

\section{MR. CARPENTER: That is an election talk.}

MR. J. B. WHITE, PARADISE, UThH. (Utah Grazine Distriet No. I): I am going to sin, any term permits should not be issued until ve determino carring capncity of tho rane and tho commensurate risits of the permittees. I holieve if ve 1ssue tera pernits wo are going to met into a lot of difficulty. It is mich easior to miko adjustments and issuo those term permits after vo dotermine the facts. Therefore, I am in favor of the amendmont to the motion. (Applause)

\section{(Cails for quostion)}

MR. PEREINS: The mike nisht melo them understnd better than I can. It seens to me, friends, that there is a lot of'usuloss discussion and since thore has beon this comittec appointed to worl out this detail in this act; and as thore seams to hrvo beon elvon to cach comitteo, certain diserotionary facts wrich rould onable tinen to act in the best interest of the district vinich they represent. And this survey committeo ras to determine the enrrying eaoneity of the raige, as I understand 1t. That should be completed as soon as fossiblo and upon tho report of the survey committeo to tho advisory boarde rould he made. Then the advisom boards rould bo alle to nat istclifiently as to the issuing of liconses or pernits. 
Now, if there eould be some modium betreen the survey committec and the advisory boards, if there eould be something that rould enable the range survor eomittee to complete that report as soon'as possiblo eo that the advisor" board might got their ruport to net upon, or whore there has been information supplied. to the alvisor: board that the car fo ahead ard act on their knowlodpo ara information together with that of a survey committee, they could coinhend ard issue those permits. And I believe the Resolution Conmittee had those.things in mind, and I do not believe we are coing to go vory far amiss if wo loave the mntter ns it is, and it rould be my suggestion that every cammittee use its orn juarment, and everyono put himself in the position of the other fellow, that wo mt. a fair and sauare deal in the mattor, that the thini: will so thromer.

$$
\text { 1... }
$$

The difficulties wlll be Incal and minor and can be aijusted to the sacistaction of the distriet.

MR. CECII: 'If this question is illustrated meh moro. wo won't know whore we are.

MR. CARPEITER: Are you ready for the question? All those in favor is Ay Contrary - No. We rill poll the delegetion.

Pirst lot me say, that there mill be no poll/takon until everybody knows what he is votine on. I have been asked questions whieh led me to believe that thero is some cloudiness as to the issue. Some have asked... rould the twenty-five percent not granted permits, read to anothor Government program of killing stock. That is not so. I have been asked if that wovld foree a reduction of that twentyfive percent of the stock. That is not so. Te will answer ouestions and eorrect any misunderstandings if you will bring them to me.

MR. WIINERY: I would like to ask if the monament carries, if wo will go back to the resolution.

IR. CARPENTER: If the amendrent is carried, that ends it. That is to say, it. will be the answer of the assembiy here thot range permits will be issued. MR. WiINIERI: It kilis the original recommondation?

MR. CARPENTER: Yes, sir.

MR. MC MURRAY: Would the advisory boord in eaeh district pass on this?

MR. CARPENTER: After this range survey is eomploted?

MR. MC MURRAY: No, thev have their own ehoico of putting this into effeet when this range survey is eompleted, is that correct?

MR. C.IRPENITER: That is true. They do not have to do it until this district is completely surveyed and they desire to do it.

MR. WIILIAMS: I rould like to eall your attention to the fret that there has been a resolution voted upon and passed this morning by tho lieense committee, that these pernits be not issued until after the rance survey has been, made. Nov, we are eoming along and trving to set asido that whieh is alroady carried. Therefore, I am favorine the amondmont to the motion - simply on, ${ }^{\prime \prime}$ those rules, that wo voted unanimously hero tris morning that thero bo no permits issuod until after this surver was made.

IRR. HYATT: May I suggest that you re-rend the resolution by the liconse commit toe?

MR. CARPEITIRP: You will listen to the rusolution already adopted as roeommended by. tho lieense committeo shieh is as follows: "liotion No. 2. RESOLVID by the National Committoe on Iieonsos, motion bu i.r. Fivatt of Wroming and seconded by $\mathrm{Mr}$. Adams of Utah, that the National Committoe favor a Donartmont poliey in issuing lieenses until such a time as tho severnl advinory boards feel that they 
havo reasenable krovlodge on which to issuo permits."

I call your attention to the fact, that the "ronsonerile knomledge" might be bazed on, thoir omn knorledgo and so it is not in conflict at the time.

JUDGE COX: This question oceurs to m nind, if wou votie in faror of this nmondmont, you have usod in the cmondment the word "completed". Vou micht make a situation like this: you misht send tho boys out and the come in with a survey, submit it to the advisomy koard, kut they might refuse to aceopt 1 t. John Doe standing on tho sido line is dissatisfied with that surver. Ho files an appoil. Thoy hoer it. They docido nininst him. He trices it up to tho Director and tho Secretary of the intorior and thon into tío eourts. Draring all that time, your surver is not completod. With that word "completcd" vou stringle what his been dono in tho other motion and here by tho amendment you tare that discretion awry and got the possibility of drapking it out raybe for six months or six joars beforo you cen get thet surve; completed. I think that vord is dangerous. For that reason I nould bo opposed to the amendmont with thrt word "completed" ir. it.

MR. CARPEITTER: I wish to offer another corstruetion of that word. When the rauge surver has been mide and laid before the Bonrd and nccopted, it will be startea to be put into oner tion and rill not mit for individual enoes to prosecute and mppenl. When mejority pret of the hoord thin's ther are ready, they will stnrt into oporation in spite of nor particular man thore.

MR. WASHIS: Doos it not ser mithin the lar that thor do not issue pormits until this range survoy has been completed and handed to tho Board.

$\mathbb{I R}$. CARPENTIR: Trere is nothing in the ln miring it necessar to have a range surve": agree?

MR. MATHS: Isn't the advisory bond and tho Dirision of Grnzing hound to

MR. CARPEITER; The advisory bond rocomnonds the issuance of $n$ permit and the Division of Crazing issues it. The tro concur in that. It clarifies this issue a little, rhich I ro bconuse these questiona we asked. There is a question which duties should the board have, and whet fhowl the Government do for them? Gontlemon, I am woll amare of tho vostorn fibling for resourecfulnoss. I filod ou 2 desert elaim in 1907 and I rnn nll my o... ditches rith a spirit level and a nail in it. In that little tow, I sortod on the Towr Boerd, and thore wis a felior in thore and wo got tojothor and cocided instoad of payine an onginoer, we would do tho rork nind save the money. Te ran sciper lines ovor nll the torn, and when we got through, we rar threo of the latorals upsido down, so the watcr run bick into the houscs. "Thon Te had to hiro an engineor, m?ich cost us $\$ 400.00$, and we hid to fot out and re-dig nli thoso ditchos. I have carriod flags for onginoors, when the mator ran stratgits up hill.

I foel tint we need solf-reliance, but the renl quitsion here is whetror you rant to be ecrtain rhon serring on the borra, or whethor you want to venture a guess on this tiling. Any more quostions on this?

MR. SMIIH of ARIZONA: I roally felt that in this advisory boards usin: thoir diseration, it may not bo altorethor a guess, ws to phether we are makine those nernits from a guess stanopoint. I thinis the novisory boarde should be careful ahout issuing thoso pormits, espeeinlly sinco ther have got the Division of Crazins to cooporate $\rightarrow$ ith them. Wo have sot the tro interested portios you advisory boards aild you Division of Grarinit. Thy don't say that mo havo to issue those pcrmits at any time. I hate to s'eo a man's hands tiod, and I want to sec them ix a position to do somothing. Bo don! t hme to mit until. tho last littlo bit hns been gone over by tho Division of Grazing. You follows are limited, and whilo I realizo that, ther ro aro linited.

MR. CARDEIYTR: I think we have opened this quostion about three times. 
WR. SMITH of ARIZOINA: A point of order. To arc discussing this amendmont. It appoars to me a ouestion mins callod on it.

WR. CAPPETTER: Are you rendy for the question to be roted on by districts? Wo will call the rolo by districts and the chairmen vill announce the result of the four votes - four votes in favor of tho motion or four votos against the motion, which is in favor of the amendment, or ho will split tho votes. Anv questions on how to vote?

All right, re rill cnll the role and take the voto dom. A vote Yes is in favor of the nmendment rhich vould he in faror of dolurins the issuence of pormits until all of the range survers are comploted. A vote lo mould be asainst the amendinent. was omitted.

WR. ADAMS: I think it vould clcrify matters some if the word "completed"

MR. CARPEITER: Do you want to withdraw the rord "completed"? Do you have the permission of the socond.?

MR. FINDIAY: Yes.

MR. CAPPENTIER: Will :ou state it?

IiR. ADils: That no pormits be issued until the raree survey is made.

MR. CARPENTER: "That no permits bo issuod until the rango survar is made".

MR. ADAMS: That will be all right. Thon your rord "completed" is left out. vote.

MR. CRCIL. The previous question has beer raised. I think wo should now

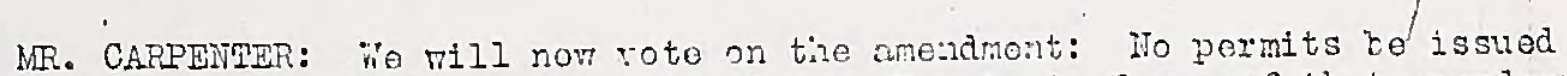
until the rango survey has beos ma. A vote $Y$ es is in favor of that amendment and a vote No is in favor of tho orifinal motion.

VOICE: Some of the voters would like to know mliat so you men by the word "completed"?

MR. CARPEITTR: As therc is no Tebster' is Dictionary obtainable, we are going to voto on this question.

(This question mas voted on by states. The list of districts was rend $b_{j} \mathrm{Mr}$. J. $\mathrm{A}$. ieoch.) 
RESULT OF POLI BY DISTRICTS ON

THE ANENDNEINT: NO PERHITS BE ISSUED UNTIL THE

RAITGE SITRVE: HLS BEEIT MLDE

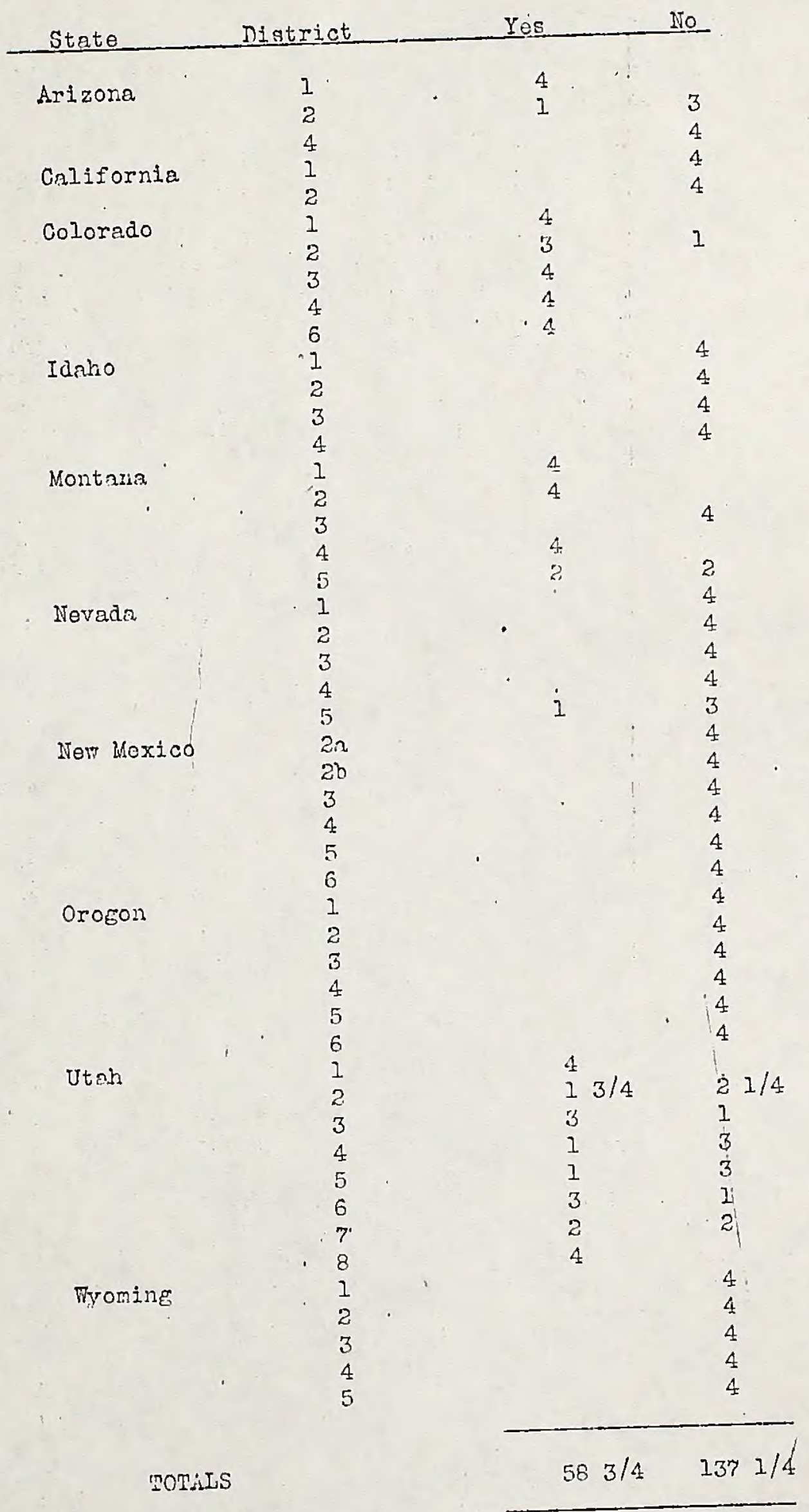

MR. CARPENTER: Rosults of tho vote: 58 votes in faror of the motion, 137 votes against the amendment. The ameridment is lost. (Applause) The original motion stinds and we are read: for discussion on tho orieinal notion. Come on up to tho miko, Mr. Vauchn. 
MP. VAUGHN, ORTGON: Orefon vigl:os to offer, as ail arendsent to tho oricinal. resolution that, rhon conuonsurate property survers aro completed, and npproved by the advisory board and the Divigion of Grasing, all Class A applicrits will bo issued peraits for 75 porecot of tho rino avnilablo, and temporary licensos for the remeining 25 percont. It is plain to sco, sentlowon, whon a district, 7 thin itsolf, can't agree vithin a Irnction of $\mathrm{a}=\mathrm{n}$. . that thoro has cot to bo some compronises minde, and I tiunk it is a cinch that soretline concrete bo arrived at so that all the advisory boards havo got somotinin to strnd on. In you linvo got a concrete policy, thruout tho prezin, aron, to back up tie advisory bonrds, "ou have got sorethine to stand on wien you render a decision.

It scons to no that a lot of you gentlonon sorving i:l 0.1 advisory capncity, must have your successors pointed out. Up in our county, we aro not in offico indofinitely. To don't knor who our succossors nilght bo. To rould like to see n uniform muling thruout tho grezing ares, that will give tho ndvisom bonrds soncthing to baso their ruling on, and re don't tininl that it is nocessary to nold up tiro issuing of permits until the range survoy is made. Fo beliovo that the advisory boavds are capale of arriving at sonowhere near the corryinf capacity of the ranso, but we do not boliove it is ritinin tho discretion of the advisory bos.ras to detormine your noi Gubor's concensurability. Tinoreforo the roason for the ino:adrent.

MR. TIILIAISS: I would iixo tho contionan from nyezen to oxplnin wing he rants to put in that 25 porcent.

UR. VAUGHN: A compromiso.

MR. WIILINIS: Why not compromise on the 100 percent.

MR. WINIERY: I ronder whethor or :ot the coneittoc on thi's report his covered the ontire situation when they say Class A. If I reriomber tic rules, Clnss 1 dofinos cornensurobility and tho standins of tive apviticant es to kis comronsurability. Class A definos phethor or not that property is dopendent upon the pubIic rance. It seens to me there should be an axend"ont there to accomplish what they rish to accomplish, and that should bc, Mr. Chatron, Class 1-A should bo put in thoro, if they aro going to considor consensurability at all.

IRR. CARPENTER: In order to clnrify this crestion, rith the consont of tho maker of the notion, I an going to try to simplify it. The original notion, as proposed by hr. Brovmfield, chaiman of tl:o conmitten, is as follows: "Resalval that the Division of Grazing issuc tern penrits unon recomsondation of the Alvisory Board in tho District affected, wich shall include 75\% of tho allot.wort rom connendes for any ranch unit or ringe sotup in projnition to comensurato property owmod or controlled; that the 25\% of the ollotucnt and numbers of livestincle shall havo a terporam licenso until sucin tino as the Ran - o survey progran is completel."

Now, as I understand Mr. Vaughn's nenduent, it wouls be to add $1: 2$ six words, as

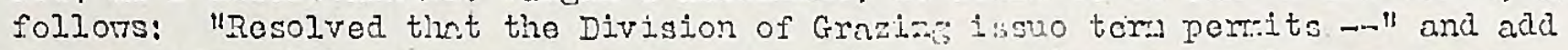
these vords: "whon the commensurate property survey is comploted, upon roconrendation of the Advisory Board -.." and so on. Would that be correct, "fr. Vauciun?

MR. VAUGHEN: Te would accept that.

MR. CARPENTER; If you rould accept that, that simply adis the works: "yion the connensurate property survey is complotod". Do I hoar a sccond to that anendment?

\section{VOICT: Second.}

MR. CARTENTER: Motion is mado and sccondod that ni anculitent bo offorol to the original notion, and that the rords, "when tho comsonsurate projerty surver is completed" be addod in the motion as discussed, Any discussion on that notion?

MR. SPAIDIIG: May I ask in what order you aro goine to nalie tho survoys of comensurnte proporty? Ho has got voted dom by nn ovorwol rine isajority "until after the raneo survoj was nade", and nor we are soing to inject a phraso that 
will hold us up witil the proporty surros is made. In mat order doos tizo Depnrtmont contomplato aking thoso survojs.

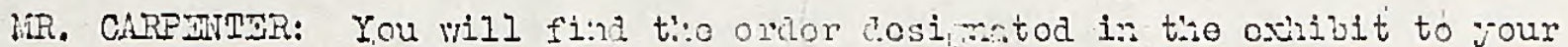

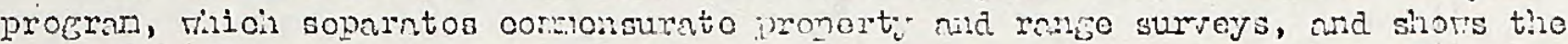
ostinte of the rance survoy division is to how soon they onn corpleto it. In the nortin, it is ono way, and in the soliti it is anoticer wey, boculso tioy can work the yoar 'round. Up horo, we en's not :inko n rongo survoy, of courso, in the wintor. Hor that will work in oach territory is sirom on ono of rour axhibits to your jrotran. AnY disoussion? Aro Jou in fnor of tho notion? All thoso i:?

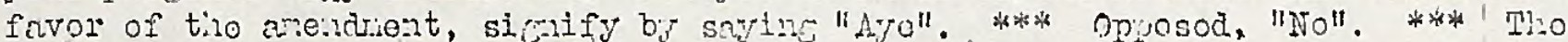
No's havo it. Aro you ready for tho oricinal notions All tioso irl favor of tiro notion as mado by tho o"airian of the cornittoo, sirnify by sayin; "Ayc": "*** Opposod, "Wo." *** Motion is carried. I vill ask the cheirrian of the contittoo o: foos and finnoes to mo his roport at this tino. THo olniman of tho mational corrsittoc on foos and finanoos.

MR. E. I. JAIESON, KIMGMLI, ARIZOMA: I Wes vory fortuinto jostoriaj, in be-

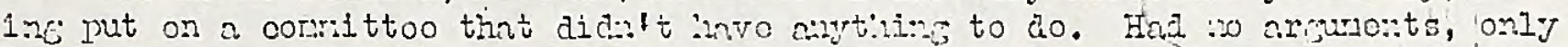
about six or sovon 'lours, sorothinc live that. Our roport, you vill notice, is siont:

"To, your mitional comittoo on foes a: finnoes, bof loavo to subnit the follonine roport:

"1. It is rocormended that thoro bo no cinno in foos for licensos during t:io year of $193 \%$.

"2. This conattoo is unanimously aroed tint t:o anttor of chnreing feos in :10v districts durinc the first yen of ndrinistration is a rattor to bo tooided by onch partialar district and tho socrotary of tho Interior, an this comittoo, thereforo, nake no recounendation.

13. It is recomended that if and won pornts nro exanted, durins tho sonson of 1937, no change shall be rinde in crnzing foos.

"4. It is recomsendod thet thoro bo no foes chrrock for tmiline licenses on stock drivowors, but where rater is proviles by artificial monis, that tho dinace be tho cost of producin; such mater, and tint thoro al so bo a cinrso for tho cost of polioing tiro otook drivoways."

I nove tho ndontion of the conitteo's roport.

Mr. FIIDIAY: Thero doos the fue cono from? Inu nro not cinreine tho drivor any foo, but you nro clungine tho foe for watorine purposes?

MR. JAESON: That mis tho intont.

UR. CAPPENPER: Do Joutrigh to net on tho yoomendations soparatoly, or on t:2o roport as a rilolo?

\section{VOICES; As a wholo.}

IR. CARPETTER: Those in frvor of ndontinc the four resolutions or fioos and

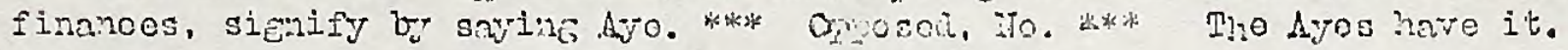

Thore has boon a littlo confusion in tilo minds of ane about a sujt to rostrain tho colloction of foes in the stato of Novncin, nil, bocauso wo do not rish any wisudorstanding on that, I an coin to ask if the is anono horo tho conos to nake an oxplanation, so that re mill know olonrly in that suit was institutod, and that pas involved in that suit. 
i.R. T. B. TRICHI, DEETE, IEVADA: I especially approcinte tho privilece, not veinc 27 accroditod delouto, to adruess this eroup, ain I vish to thank not only tic G'air::an, but tise state dologates, for tize courtesy extended to Nevadh., of allowing us a fer no:lonts to oxplain our yosition. You know, when a corr ran tajks on tecinical. lo,rl quostions, he is in a lificicult spot. Tincieforo, I trust no ono will ask no toinizical quostions.. I think lir. Campenter has alreais aven no tho ansvor, only, in $-\mathrm{y}$ caso. I rouls stato I don't liave any lochl volunes with wo; tliercforo ve will go forward. Wis reforanco was to tho dictionary.

Last zear, I had the honor of presentirs yerain's cencrnl stateant, and, at thet

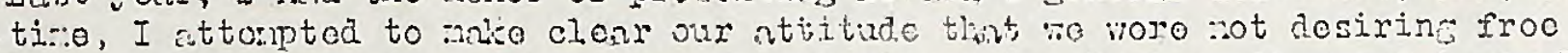

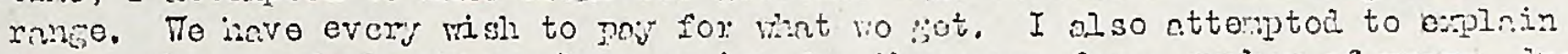

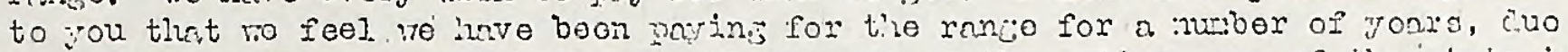
to our tax setmip, under which only 11 jercent of tire antiro aron of the istate is in private omors'ip, one half of that il perecnt bolonging to the rain roaks and which land wo leaso. Thercfore, it is not $n$ question of free uso vorsus pay.

As \& jround rork; to clarify our nositinn, I inst cnll your attontion to the rifferenco between tho Taylor Grazing ict un the forost sot-up, anc; in so doing,

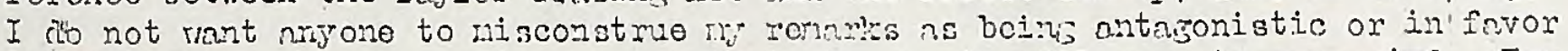
of oither sot-up. I simply prosant fnets to $y$ ou to till ovor in your nind. For

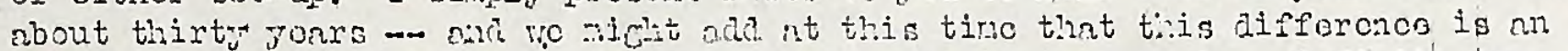
important consideretion for you, wue to tine fnct tint thoro is a darinitio rovo to coucontreto tiso two grazin servicos eitlicr under the Dopertaent of A sriculturo or tilo Depert:zont of Intorior - for about thirty joars, jou hinvo bocn oporatinis

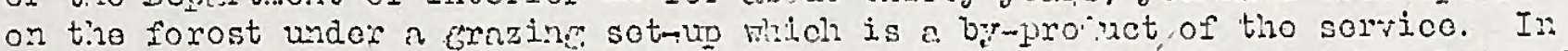
othor rords, grazine is socondary. You nre rejulnted by dopartnentel rulos and reculations, solely. The Forost act res brount ebout by a presidentinl proclara tion.

If the Tarlor Grazine Act hos any ono creat advantäe,' no has boen pointec out to you by Diroctor Carpontor on nany occnsions, it is tho fnct that you havo a basic law, designod primarily for crazine, and desimed to strbilizo the livostack incustry dopondent upon tho piblic rrines. Non, thon, craning is the first co:ssidoration undor tio Mnjlor Act. This fict not only limits those who aro to bo rogslatod, but it placos cortain adinistrativo liritntions upon those who aro dirccting application of tho act. Our theory in Novada is simply this: if ro have basic Erazing 107 , it is hifhly importait that conauct undor tho lar be confinod to tino li-itations of tire lar, particul.nrly in tho initial stasos, for tint is" whon tho dio is cast. If you cet arry iron tho lan, it is just a natter of tiro until you luve a set-up wich will bo cortrolled ontiroly by cicnarticntal regulations.

Now, this suit is a friondy suit. I riert say to $j$ ou that the relations betwecn the stock won of Nevacia and the Departiont of Granine are rost cordial at all timos. Fo lavo no antaconise over thero. To aro not attonptins to be obstructionists. I. think it is a ratiax sliort-siutod vion, to consider that an attont to crystallize law is an obstruction. To lave, on occnsion, henrd hr. Capontor state that lany of theso things will bo irotes? out thru a perios of ycars, rela. tive to crystallizin; antisuous parts of ti:o $1 \mathrm{n}$. Tho. Dopartnent of the Interior has thoir loenl alvico in thoir solicitors' dopnrtnot. Tho indivicunl stock nar. has his lobsl advice in his attormo 3 s. Inch, of couxse, has confidonco in his logal advisor. However, as in all thincs, diversifications of opinion arise, anci, in our pnrticular case, our attorne:s ndise tint a fce undor soction 2 of tho Act is not logal.

The question, thorefore, arises: Do nc visi: to brusl: asido tlic tochnical lecal phaso of it, and rcoppt a foo, or do ro wish to abilo oy tho law, which provides, in soction 3 of tho Act, thet the Secrutnrer of tho Intorior mer collect a ronson-

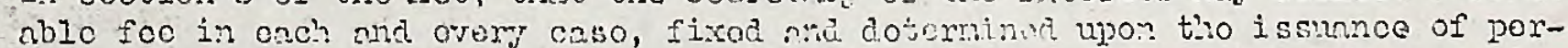

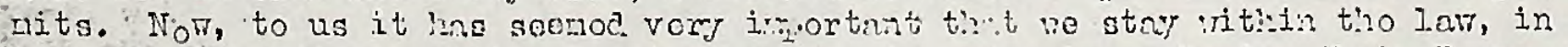

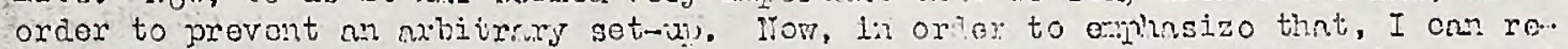
for you to tho hoaxins beforo tho varjous en:urossinen comittoes, and. on various occnsions, oux lofislators voicol niproinonsion locletive to a covoment

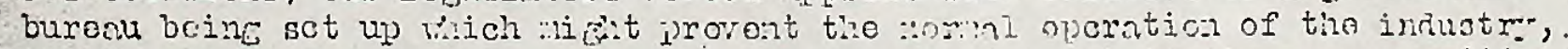

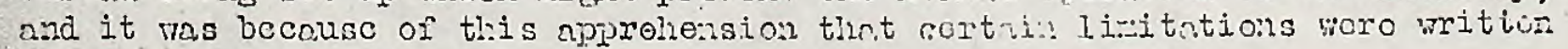


into the het. Now, there aro othor foatures in this Act, if ono was out sirnly to enuso headachos and be an obstruetionist, that wo boliovo could be lomitiratoly attrelsod. Mint is aot tho juryoso. Tho jumoso is to erjstallize nud to dotermino whotior or not a Dopartwont ca: put their orm interprotations upon this Act and con strotch it to such a brond oxtont thot, for oxuplo, under seetion 2 , they ear collect a foo rithout the issunneo of porits. Aduinistrators of tlio lan - and I thine that $2 \mathrm{r}$. Carponter is 20 oxeoption in this; in finet, I' r. suro he is not $\rightarrow$ velcoie atteapts to brins about such erystallization aud clarificetion, and tho soonor these thisus aro settlen, tho jettor.

Now, anothor linitation in thoro, to bring out whet I roforrod to as restrietivo linitations, is tho so-callod MeCarron linitation, which wes reforrod to this nolnine. It is smited that a for rorcls $i$ in thore noro ratior unforivunto, jut don't be eonfusod in the foaturo of tho provision, which proviles thit tho valuo of tho grazing unit shall not be impirod. That is tho essenee, not that a man may be in debt, and that is one of tioir rostrietivo linitrtioss.

In o rder to boar out rhat I have said, witl rogned to this boinc a friondly suit and aot an attack upon tho Aet, nad not a.m a.tompt to obstruct it, I vish to read you the opinion of Jukce Yanhich of the Feciernl Court. You know, rttorneys

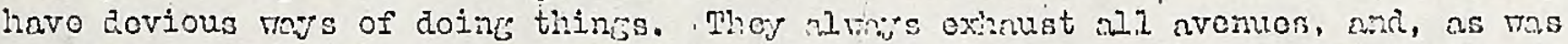
expected, the orioinul caso, filod in the state court, was transforrod to tho foderal court by tho Goveruncant, tho renson boing that the Governent raintninod the state court had no jurisdietin.. Sur nttornoy maintninod, for technical ronsons, that the federal court had no jurisilietion.

In the first heat, 70 won, as 70 aro nor bac: in tho stato court. But, just to elnrify the pieture with rogard to the Act itsolf, I wish to rend you just a brief statenent takon fron Judge Yankrioh's opi::ion:

"The plrintiffs do not question the rist of tied Uniter Strtos Govommont, timu Condress, to rofulate the use of any part of its public donnin, nor do thoy quostion the right of Congress to enat the salor Grazing net or the dalegation of porrer to tho Soeretary of the Interior uinder ti:o Act, to requiro tise pewent of a liecnso foo. Thoy assert a ridht not contram to the set, but one under it. That is that richt? Breh of tho: asks to be rolioved of the pa,jont of grazin; fees by virtue of elaimd authorizod rulos and rogulations. Thou question tucroly tho ritht of tho Secretary of the intorior to deranc a liconse fee for $n$ toriporary, rovocablo poruit."

In this instanee, he uses the rord "per:it" in place of "Iiconse". "Thit is the essence of the suit and the purpose of the suit. At this time, I risi: to refer you to our statoment last year, that Novada stock mon stand at all timos rendy to cooporate and assist in the furthernnee of all construetivo attenpts at rango reculation, wikl we recognize tho necessity of. Thank jou.

MR. CARPEITER: I con and nothing to thit clear stato::ent, oxcopt to suy that, as a lawyer. I Glow in the fact that wo havo a systen of covomront, whereby any citizon, no zottor hon hurble, con go to tise courts and quostion any adrinistrative dopartacnt, no mattor how croat, and wo, of courso, mish to pre serve that, and tizis is a dononstration of that richt boing prosomod in that way.

GENTIERAN FRON WONTANA: I nove that a Mimoogrnphod copy of this addross bo sent to call advisory board.

UR. CAPPENTER: It will be includod in tho record, contlonon, and ro cxpect to nineograph the entiro rocord and nail. a coy to overy district advisory nombor in the United Statos, so that you will got a record similar to what you cot last yoar, wihlch vill ineludo all tho debates, rosolutions, votes, and overithin: olse. Will the elnainem of the cormittoo on ranco improvenonts present his report? 


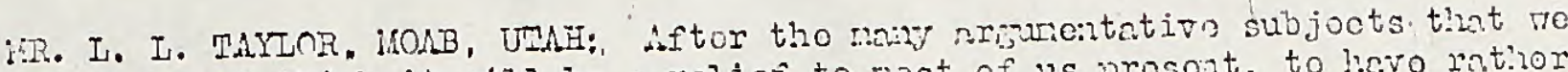
havo had today. I thin it will bo a relies to nost af us prosont, to hevo ratior

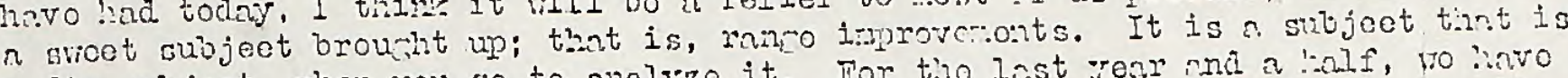

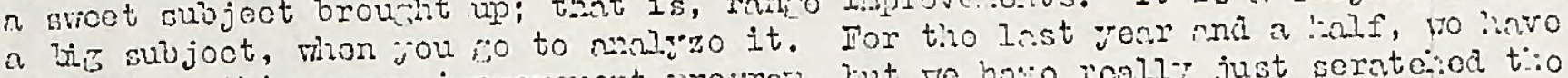

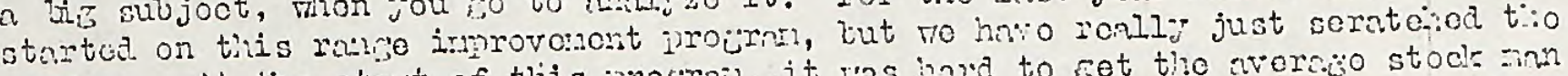

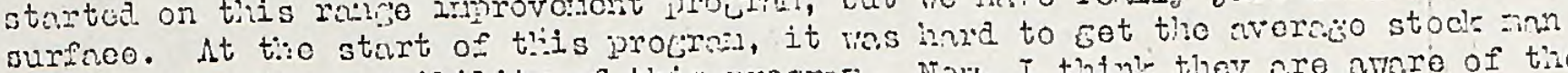
to visunlizo tho possibility of ti:is urocru. Now, I think they are avare of tho fino rorie tint has boon ciono. I invo sore rosolutions tiat ton't eovor oveinthing that tho comittco sucrostak s.ould on orount up. In tho first plizec, re

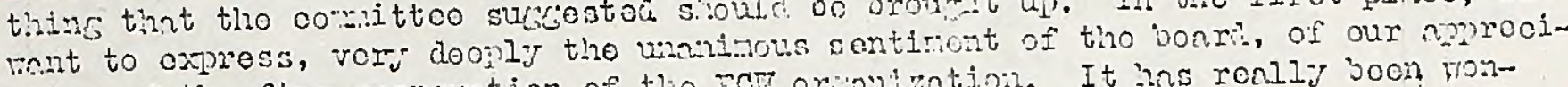

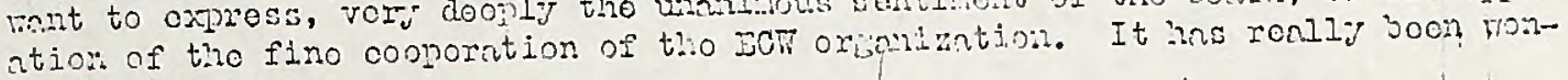
corful.

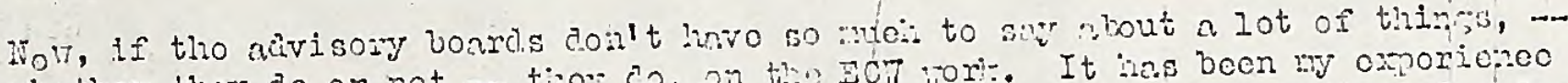

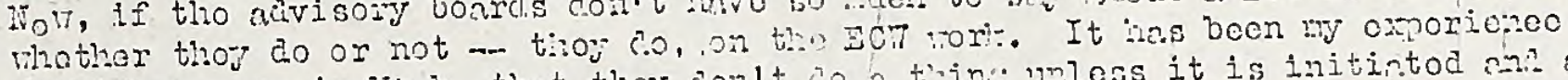

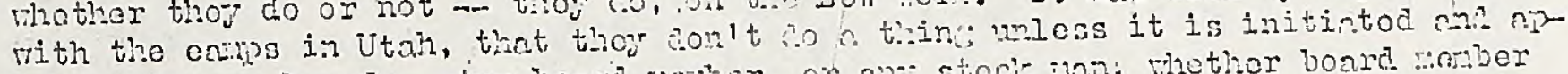

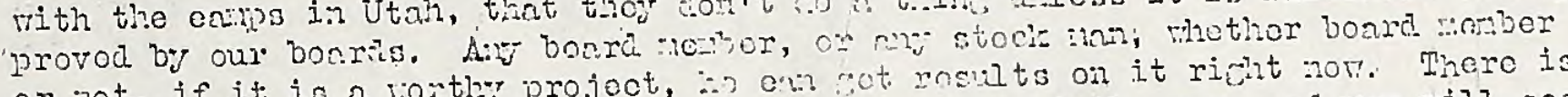
or not, if it is a routlew projoct, $\therefore$ en not rnsilts on it richt nor. There is

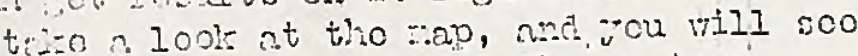

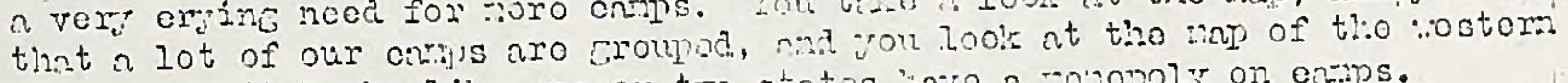
states aid it lools lizo one or two stintas :avo a mopopoly on eams.

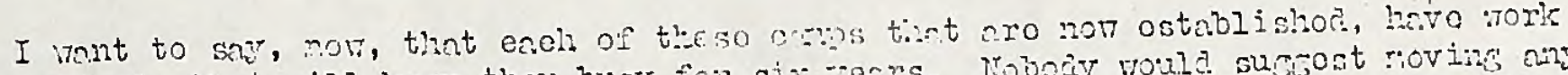
projects the will koop thon kusy for six jerrs. lrobowy would sucost roving any of thoso crmp unloss that is the list. stop. Te icel thet tho other statos, that

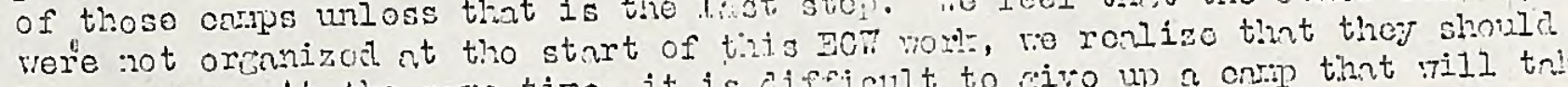
hrve enips. At the sar:o tino, it is rifficult to ripo up a on:p that rill trico six yenrs to compote thoir procran. Our rusolution is to insist on ropo coups. I wouli like to nention a fow illustrative projects in somo of tho statos. For instoneo, hero is colorno, thich ins nout 15 or 20 ?ifforent tijnes of projects thoi have put over. I rill just piels out ono: 25 reselvoirs, arorogo oi wht acro feet por rosorvoir. Tint he boel dono in a litile oycr a vonr.

Hore is Utih. Here is a $7 \% 0 l e$ pao of trpos of projocts. Hore is ono steel bricco, two spane rido, ono $100-\mathrm{ft}$. s ma nil ono 60-ft spaz. Hore is Uteh ncoin, Cisco Sprinss, a pipo lino projoct. his is pojoct vill be cosploted ritinin two vooles, anc will brine wator dow over r. dosort cron. This project vill brine weter dow to tilo stock drivowy, sevon nilos, were there nover was vater beforo. Here is Ianlio, oraliestion of insoct pests, such ns nomon erielots, over six t.ousua acros, poisonins of roctents; the has boun corrich on in on oron of six tinusoite nerus. Traj ing of prodintory nni.hels, over 50 tiousnd acros. Hure is Arizoan, construet and lovelop the Ho, Spir Spin Reservoir, 700 foot.

$I_{0} \pi$, I an coins to road tho rosolutions and Iet it so at that, but out in tho" lobby horo, or tho corricor, thoro wro a lot of ninrative roports, and tliosp interosted rill do roll to step out there and read those armitive reports. ITor I vill reni tio resolutions and I vill be ti:m:

"To, your courittco on ran;o improvenents, comprises of 20 Bonre nostors fron tho ten westorn states uncer the juriacietion of the laylor Act, wish to cro nn rocord

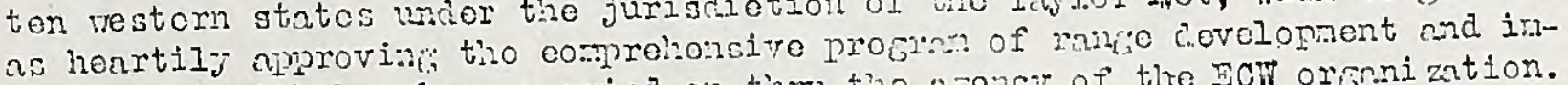
provenent which l:as boen enrited on thru the honcr of the ECW orgnization. This conitteo, ropresentinis pratiell stocluon of the restom stntos wio havo ob. sorver tho operntion of tho CCC prourn: thim tiso verious Goveranental ajoncios, bolievo tint frentor actunl dollars and conts viluo is boing roceived fron the Division of Grazi: eaps t? fror ar othon unit. Fo are sincero in our stnte-

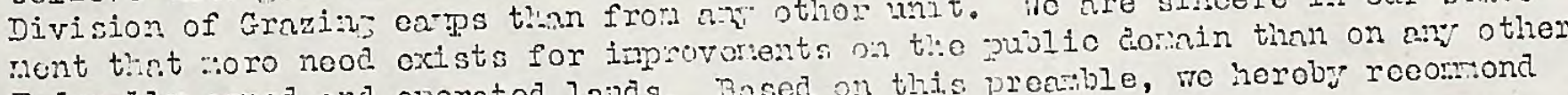
Fedornly ormed and operated lands. Bused on this preatble, we heroby reeormond. to this assorbly. thent the followir; ronolutions be mlopted:

11. (A) Te recomond that all Division of crazini: cans be eonfined rithin rochi-

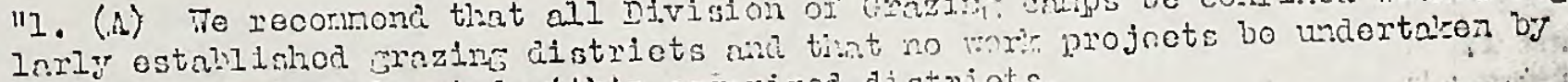
sucli comps unloss loented vitin orconizod distriets.

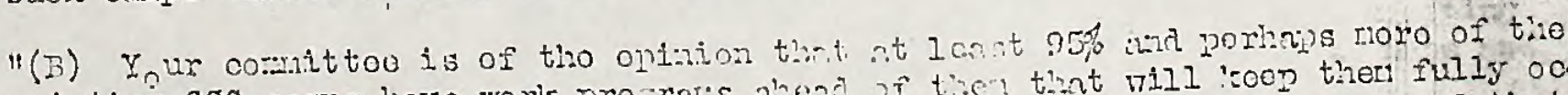

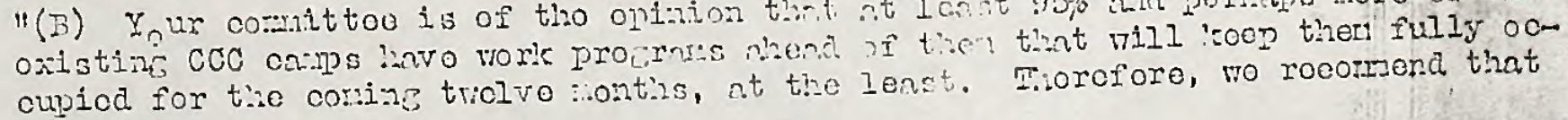


that the canjs $10 \pi$ ostrblished, rilicil have now projnets justifing their futuro axistcico, io not isturbed $\mathrm{ky}$ sensoulal rifretion. In this competion, ro noint out that the vast majorify of Division of Grazine Cngis aro locnteit in aroas

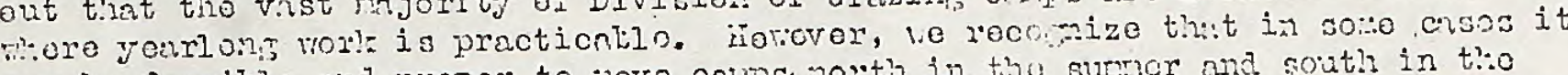
ring bo forsitle aic. propor to sove entrs north in the surmor and routh in ti:o vinter, depciding on seasonn and clinatic conditions of tho various arcas of the

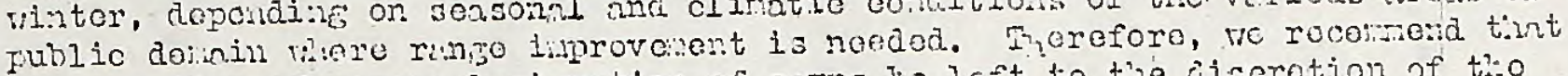
the question of sensonnl mistation of cups le lest to the discretion of t?:0

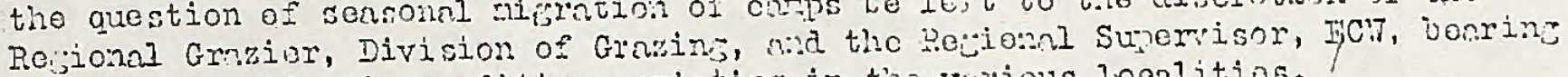
in simen tive elimtic conditions oxistin; in tho viaious localitios.

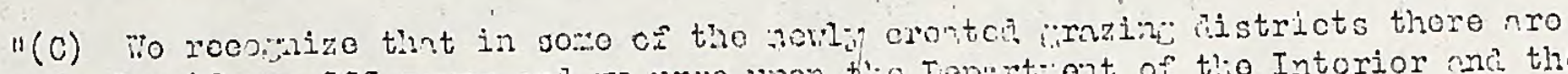

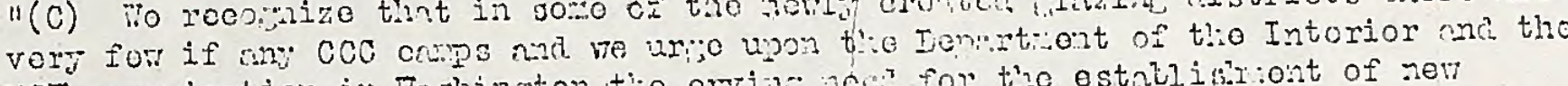

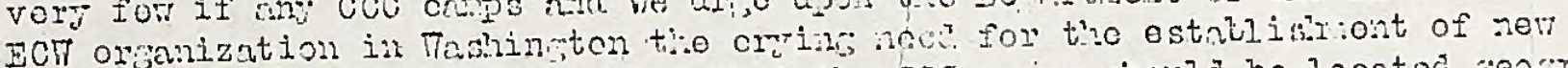

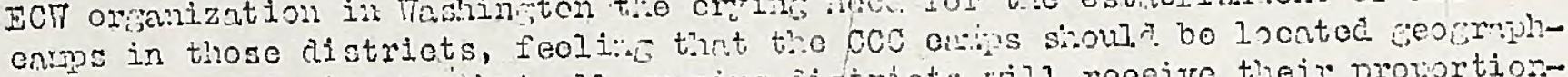

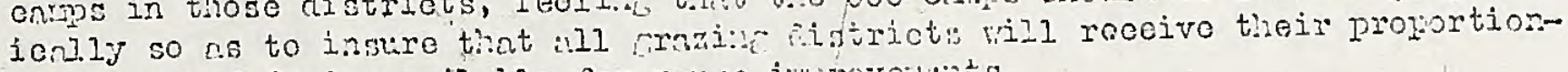

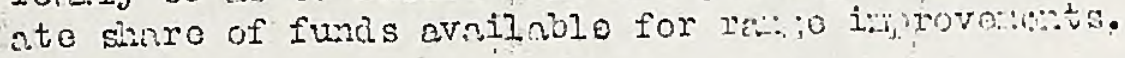

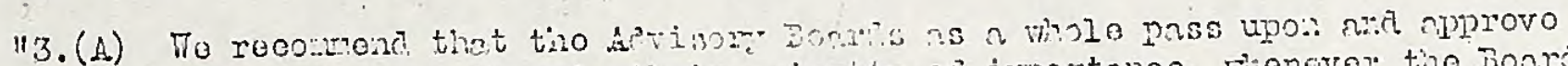

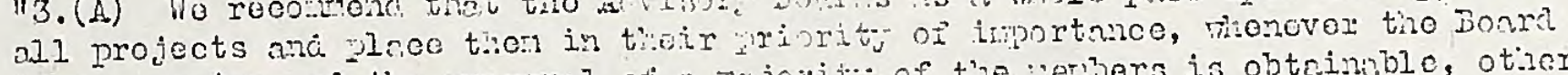

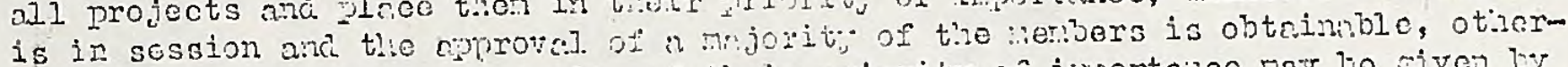

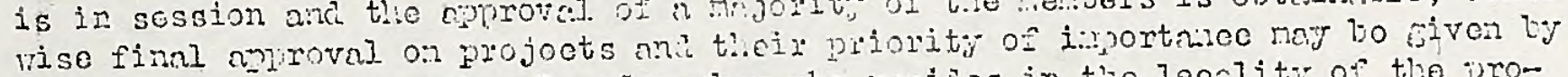

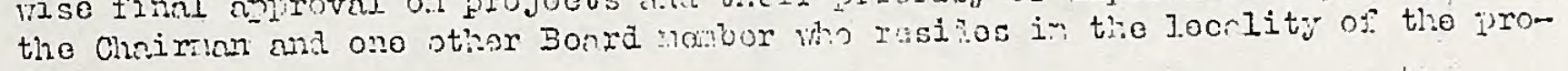
ject.

II4. Te aro positive thet the Diviniom of Grazin, possibly due to its recent

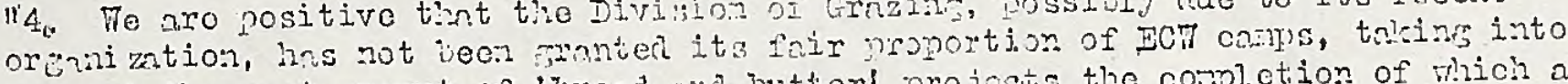
cocount the vast amunt of ivread and rutters projocts the completion of which aro vital to a papol adrinistration of the ixnzin resoureos of tho public donaim.

"Te rish to point out that the miolic dornin corsicts of 142,000,000 ncros, na

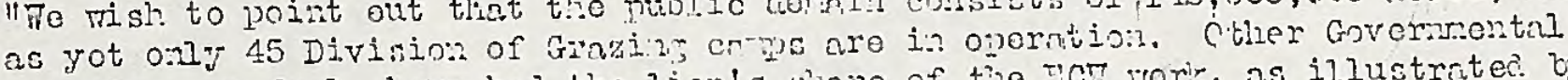

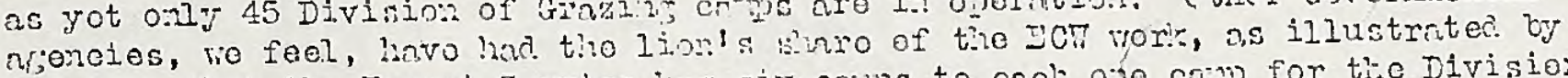

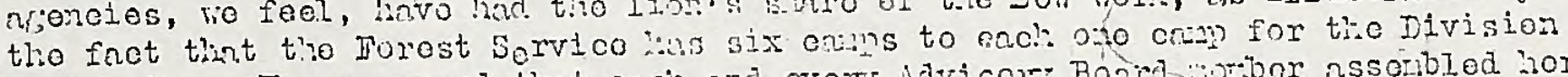

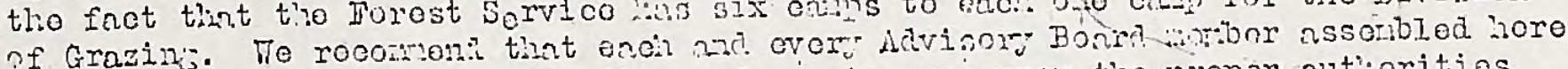
today constituto hinself a conittec of ol:o to urio upon tio propor auti:oritios that r:ore Division of Granize entps bo estahlialed, to tho end that oreng srazing distriet be (jiven at least one croy, na ns man moro as thoir meods maj recuiro.

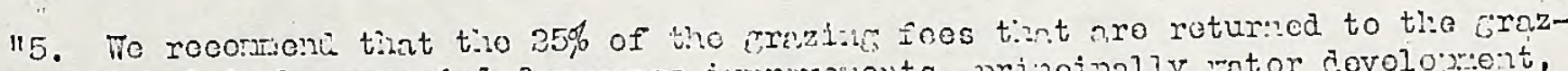

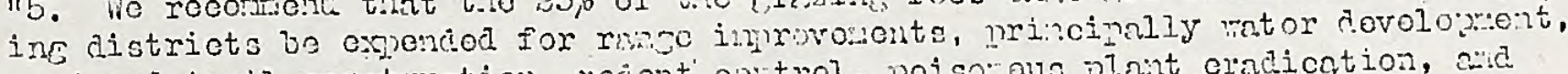
roo: and trill constuption, rocent cutrol, poisonous plant eralication, and

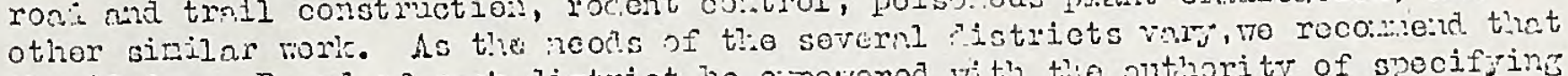

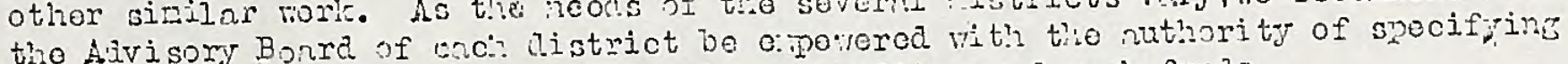
wint projects shinll bo opproved for tiso expendituro of such func.s.

"rhose resolutions vere dioptea this 10til day of Doce:ter, 1935, by the contittoe

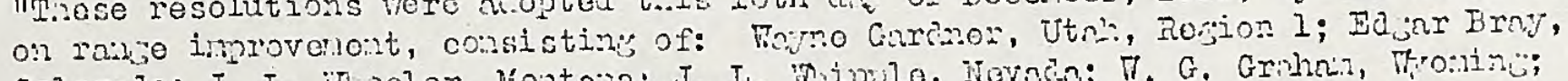

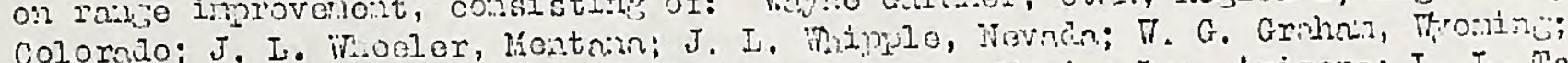

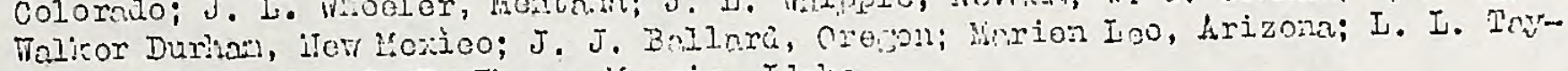
lor, Utah, Rouion 2; B. Mi:orns Yorris, Iinho.

Mr. Ciairian, I rove gou the niontion of ticso ronolutions."

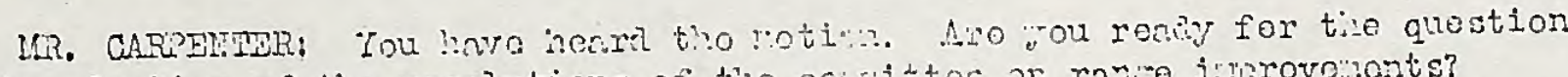
of the croption of the resolutions of tive contittec on ran;o inprovomonts? (Calls for question.) All tioso in fivor of tin nioption, sichify by sajin:

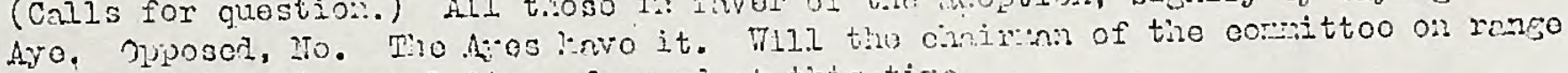
survoys brin̈̈ lis resolutions forvarit at tinis tira.

MR. J. if. SIIPH, ARITilh: Four nationni crittoe on rnaje survejs bor to report as follows: Tho corwittoo on rano surfors, wectins josteriny with lr.

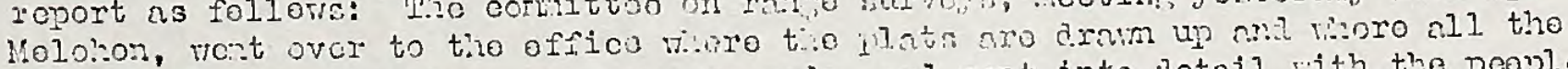

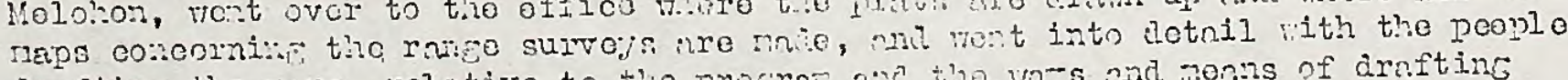

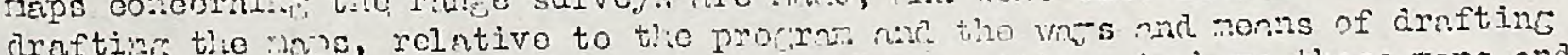
these mps. It ma a vory srent holp to tire cointiboo, to hovo those mupe and 
plats plecol soforo than is order that thoy any find just hor tho Rivision of Grazine is opernting in maxing tive rango survey. To thon roturned to sur contittoo roon and hal a grent denl of ascuseion over rano survcys. It is riy privi-

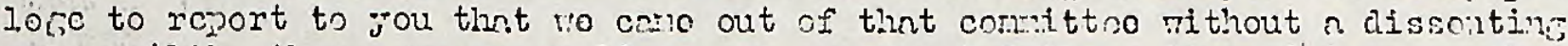
voto. Altio thero woro nany ichons, we consuranted those linens into a rosolution winch wos unaninously anoptod, by tho comittoo nue then tumod ov or to tho rosolutions com: 1t toc for ti:o:! to draft. To wisl to subait to you nt this tiro tho rosolution as drefted $3 i$ the rosolutions courittco:

"Bo it rosolvod, thet the objoctives, stancinres of mon" and not!nods of procoturo non establisliod by tho porsonnol of tho Rns:io Survejs irnach of tho Division of Grazinf bo approvod.

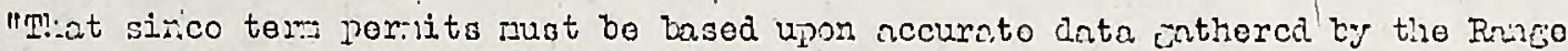
Surveys, this work bo expecitod by an onlarisod personal.

"That the Rnipe Survoy porsonnel bo instructed to Givo first profore:zeo to tho various linds of work as follons:

1. Dopolicit proporto survors in the rogions linoro thoy forn tho basis for liceises.

2. Actual ranjo survers in regio:is vihoro dopenciont proporty survoys aro not neoied.

3. Actunl rnine survors in rojons tikero tho dopondent proporty survoy has boen completed.

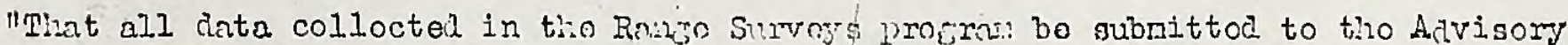
Boards concorized for their approval.

"That all Advisory Boards cooporate to tio fullest oxtont vith tho Rnize Survojs persomol and furnisi all s.vilable date covering lands within thoir rospoctivo districts.."

$M_{r}$. Chaimain, your congittoe on rance survoys subnit this roport ond now nairo tho notion that tho report be adoptod as rone.

IIR. liAFAFTEY: I rould liko to socnd thet not1on, and I rould liko to sny furthor: You naco the statonont hero lny beforo

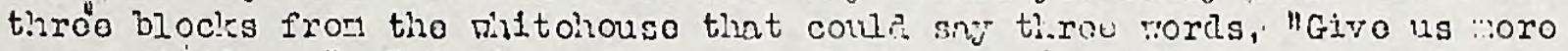
appropriations." I bolleve grou con $\ddot{0}$ o bac's nila ruport to jour suporiors, or Coniress, and say that overg stocl: mon in tho wost is in lunrony with that in ghouting, "Givo us inre appropriatio:is, 30 ro cni pot tilis survoy corplotod ns quickly as possiblo."

MR. CARPEIVTSR: You have loark tho ronci:n; of tho rosolution. Aro you roady for the question? Those in fnvor of aloptina tho rosolutions subsitton by tho comitteo on rnnje survoss, sicnify bj sojine Avo. Opposed, Na. *** Tho Ä̈os havo 1t, and tho rosolutions aro ndoptod. I an zoi:r, to ask tho First Assistant Socrotary to take tho Cair at this timo and he vill call on Jud $\because \circ 0$ Cox, the Chairun of the Iosialative const too, I boliove.

MR. TALTERS: Inilos aria Gentionon, you can hoar ne vithout tho "yike", can't jou, back thore?

\section{VOICES: Suro.}

1KR: RAJTERS: I novor had rucl trouble boins henre boforo nivoriy oxcopt

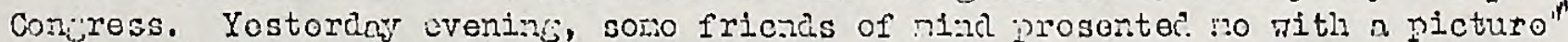

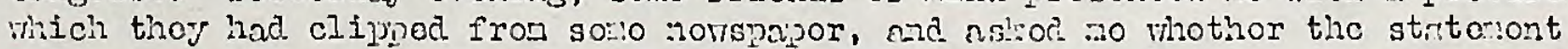
najo at the botton of that picturo vas correct. I rend thru the printoc nattor abovo the picture nil bolow it. Abovo tho picturo, it sns, "Iallks on grazi:nc".

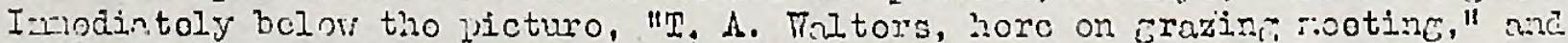
richt at the bottoa of that, 1modintely bolor tho lint statcriont, it roads; "Plonds not cuilty." On a closo onzination, I founci, hovovor, that tinso gontlomen had boen doi:1s sone tinkoring with tho nnttor as it caio fron tho pross, and thoro is a Iino thero indicating thor hal ioldoe it ovor and, I think, pastod

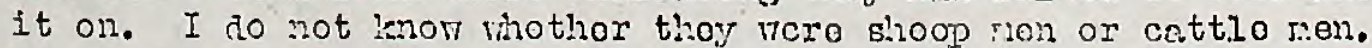


That puts no in nind of that old story on Carpe:ter - I tinizl ho has loft

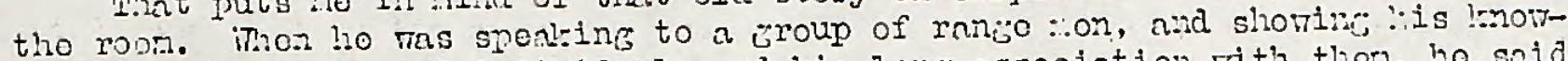
lod;o of the rni:;o and individunls and lis lon; association rith thon, ho snid that he could pick out the s'ueep non and cov non by tl:eir apponraineo. Ho reforrod to one man over hore and said, "You are a sheopren, aron't $\mathrm{Y}$ ou, $\mathbb{K}_{r}$. Jones, "nad he saic, "Yos, sir," ani lie saik, "Sait', jou are a cottlo man, nro:2't :-ou?" arit ho said, "Ies, sir." Ho wns piakin; thon out rijht along. Hero was a bifs now who hnd beun only a for jenrs from swodon, who had just cone in fron tho ranjo. Ho snid, "Mr. Ol son, you are a shcop min, nron't jou?" "ollie" roso up and he sald, "iNo, $A y$ bano no shooj man; AV ohno sick nooot six nunts, nal mo look lak hell." (Laughtor.)

To are ampononin the conclusion of this rootin. I as going to call or Jus co cox for his roport in a alnute, but lost, peralventure, ho ni Gist talco the tino which I should consuse, poninjs, I rint to nare a for observations. I havo, as $y$ ou know, boun at this i:eeti:n sinee its incoption. I lno the crent priviles of veine at the first nootins; of the lind you evor held, alrost a yonr ago, and uy interest 1n the meoting and in tho nen and nomon who attond tinoso mootings, incroasos with t:e nurber of tinos I attond and associnto rith you. If you accomlish notiln ol so but cono hero, as you do, air associato ore rith the othor,

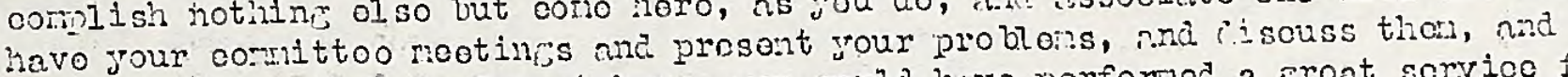
sornotimos cuss thos, and went howo, you woulc have performod a eroat sorvico for the otion fellow and also for vourscif.

To find, by nssoetntine touctior, thent nono of us nro iree fron lroklons and that the othor fellow, over on the othor side of the ranio, has sirilinr isroblens to riknt you savo on this side, and :aybe he has a littlo aifferont problon thain you have, vut, by jour coneration and discussion, rou 1llustrater the proulcns and rany tir:os assiste. onch othor in eolvin; tiron. Iou noy not be satisfied or contented, but you have cono a lon; nny tornres both.

Spoaline of "sotisfier. n:a contented" rer:inds : :e of tho instance rizoro soneone called upon the Irisizin, to distinguish iotven: tho word's "satisfied" and "contonted", nind lio pausod for a minuto and :o said, "Toll, sir, I an satisfiod that I an marriod, but. I'. dann buro I'"not contontea." So that is larpoly our sotisfaction on tho ranco. Fo are sntisfiod that wo aro out horo and wo havo our problons, sut re are quite suro, somotizes, wo aro not enntontes. But wo never

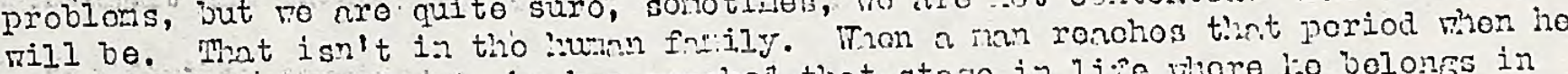
has absolute contentrent, lic hns rencho thet staio in jise wore l:o velongs in

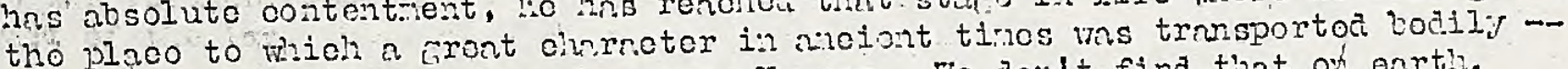
to tho otherenl roulas ajove movm as Honvon. No don't find that ox enth.

Our problass are aipable of solution toiny, but tonorron there nro nor onos born. Tho Dopartnent of Interior is most vitnll 3 i:tcristed in rour problons. Many of us who have to do vith tho rano have personal knoviongo of it. Wo havo slept in tho enips; re havo enton tie souribug il til plensure, "nnd the bacon. Sonctimes, oven trou, it wan't cookea acoorin; to tho nost mociom nothods, it tasted bettur thoro then it over tasted in the bost hotol I have over stopmod in. (Aplause.) I havo scild, may tir:es, visen voing out nid taking ainor at tho carp, tint after baike out a for chys, wh, I have a stonach like a com shellor and bovels winde of b'ilor iron, so whatovor is sorved is cood nixd dicosts porfectly. I can recotrond it to those nimo iavo, real stomehs or bal dicostion.

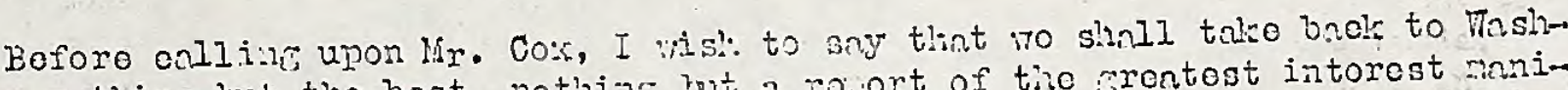

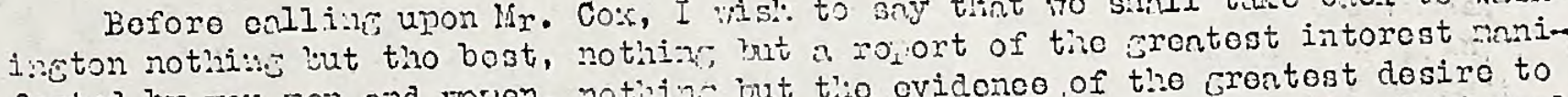
fosted by you mo: and monen, not?in; but t':io evidoneo of the grentest desire to

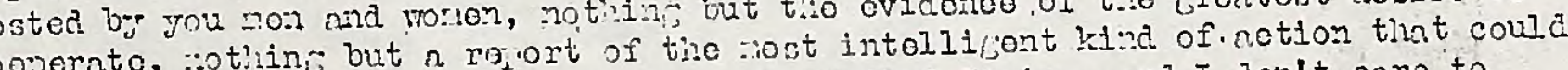
bo ha by niy body of ron assoniuled in t::o U.sited Strtos, nne I c.on't caro to rhat businoss they bojone. (A Iniso.)

I stated to a youm an -- aid $\therefore 0$ is : :oro, irobably nould ropoat tho statio-

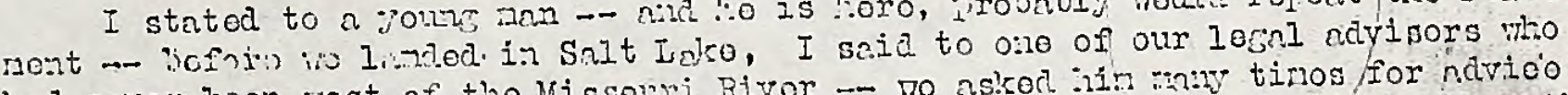
hed nover boen wost of tho Missouri Rivor - no asker hin maty tinos for ndvico

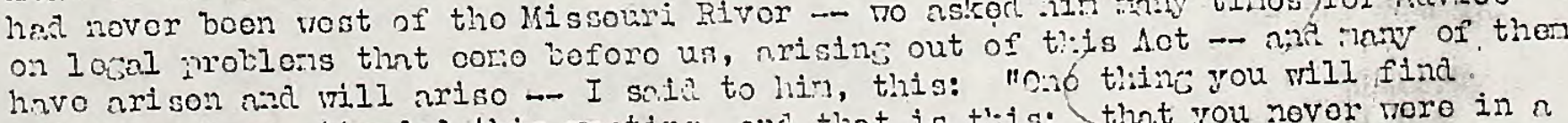
nftor you have nttendod this crootini, nee that is t':is: that you novor nore in a rootini; whoro mon exprossod thonecivos as fenclossly and necuratoly and to tho 
point, and as intellicently, as you vill find these nen expressing thonsolvos . I saicl to hin: "Is you could get a eroup of nen of tho saro nuruber, of the so-called industrialists of tho enst torether, tircy rould fall short of that capacity to eavress thenselves and to copporato, which you rill find ar:onis tho st: $0^{\circ}=$ : :u: of the rest."

Non, I think I have talked to you lonf onough. I have had the privile; of talkine all ovor the west and not lone ago - I rill toll you another story; wo havo sot tine for that, I guoss - - it anusod ao whon I ras talving about tho social. sccurity question, and the chairrial of the occasion ma a pronchox and ho took Groat interost in tho subjoct of social socurity and lookod upon it partly as a roligious anttor. Beforo ho concluded, ho took occnsion to speale at so::o lonith to tho audionce and disi;reo sor:ovhat with riy concoption of tho socinl security net as passod by the Congross of tho Unitcd states and signed by the Prosidont, and ho said to his audionco vith gone ontlusiasn, quotine tho Scriptures: "What ro nood, ladies and sontlcmon, is a condition in this country whore ovory man of us lay rost vononth tho ;ratoful sharlow of his orm. vine and fic tree, and nono sholl aake l:irr afraid."

It was a beautiful concoption, and ho has jront applauso, and ho ropcated it: "What ro nood is a condition in this country whoro ovory nan of us nay rest bem neath the Grateful shador of his om vino and fig troo, and nono shall thise him afratd." With larcor applauso and grentor onthustas on his part, ho repented for tho third tino, and with sono mistal:c, porinps, he said, "Iarios and fontloslon, what ro nood in this country is a condition wero overy nan of us naw sit

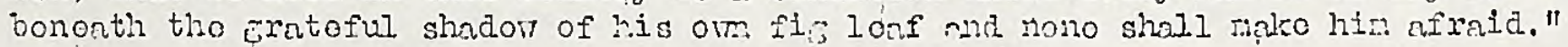

Now, hr. Cox, if you will cono former, wo will harr your report.

JIDGE LEROY COX: Your untional conitto on lofislntion has unamirnously adopted tho following rosolutions, for vour consideration:

"It was uniziaously rcsolvod by this lo;islntivo coutteo thet provision be rande so that the $50 \%$ now going to tho state to be cisposod of by tho lerjislatiure shall be turnod ovor to tho grazine, bonts whe tho grazing land is locnted, for the

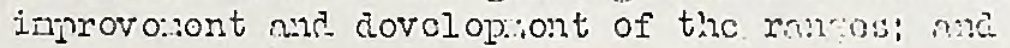

"It wns furthor rosolvad thet we recoment tho form of tho followin; proposed. araft of the law, which will corry out tho purpose of ti:o forogoing rosolution:

"Proposed Modal Ian for Stntes for Distributio: of Eedoral Funds.

"Scction 1. That all funils roccivol bit the stato of provisio:ns of tho net of Congress of June 23 , 1934 (48 St.t.1269) lc:om ns, the

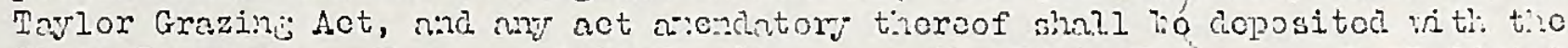
Stato Troasuror. Upon rocoipt of snid nonoy, the statc Trocsuror siali distribute tho saro to the severn countios of tho stato in wich such public lnas aro locatod. The Stato Trensurer shall ascertalin fror: the propor Unitce States offiors having tho records of roceipt fro.. rrazi:n porits and lonso and solo of pubIic lands tho anount of recoipts from such sourcos in this stato for ench your For which ionoy is receivod by tiro state, nd a scparnte nccount s'all bo kcpt of tho sur rocoivod froil cach Erazing district and loase and salo of public lands, which sui shall. bo segrockated by tl:o stato Trensurer and paid to tho county in which said razing district or lensod public ln:2d is located; and if nay such

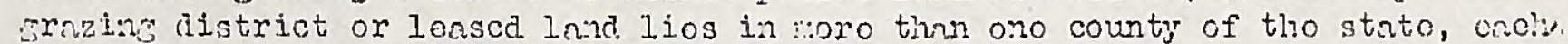
such coulity sinll recolvo such proportional. amount of said surs as the inron of

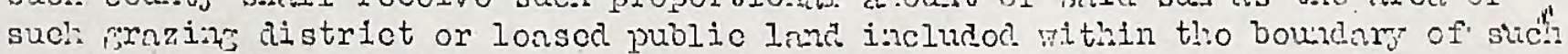
county shall voar to the total aroa of such srazling nietrict or lonso.

"Scction 2. All :onoy rocoived from tho lonso and snlo of public londs rithin tho county. shnll bo placod to the credit of tho genoral sci:ool fund of tho cnunty.

"Scction 3. All nonor recoived fron Grazing foos of ce crazt:us district reglarly

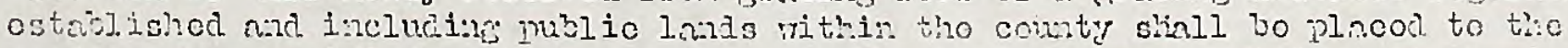

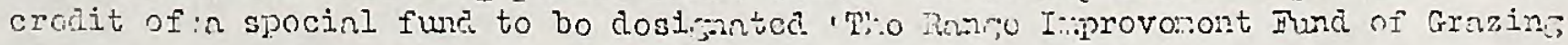


District $\mathrm{No}$.

1 The Count: Tronsurer of the county.in ritich such jublic

lands aro locetca shall bo and is hcroby constitutod t'so ox-officio district tronsurer of any fedoral crnzing iistrict locntod in wolc or in part wit:2i:2 such county, and simll l,o linble upon his oficinl bond for tho propor coro and aistribution of such monoys; nnd ho shall colloct, rocciro, receipt, and nccount for all : :onejs fron such sourco. Tho Couity Tronsurox, ss suc!l ex-officio Grozins District Troasuror, shnll pay out such nono upn tho mrrnut of tho Grazing District si-ned by tho Chair:nn of th.o Eonrt of Itistrict Advisors of suc': Graziac

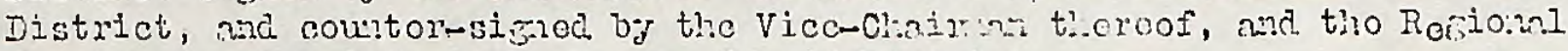
Grazior in ad:iaistrntivo charce of snid District.

"Scction 4. Snid noncy fron srazin feos of Grazi: Districts shall be onjo:kiod as tho Board of District Advisors of sucl: Grozinf Iiatrict :-ay circet within snid

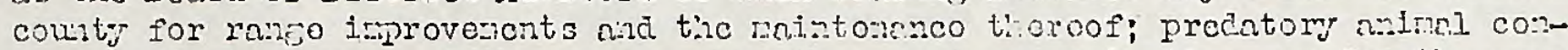
trol, rode:t control, poisonous or obnozious sood cztomination, or for tic purchaso or rental of facilitios or lanns within such couty rich mill wonofit such crazinis district or the part theroof riting said county."

Since vo have a number of rosolutions, with cisfer ns to tioir intent, jorluns

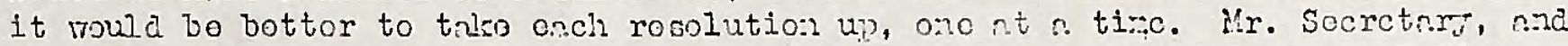
follow nomors of this dolegation, I aovo the aroptias of tho first rosulutina.

IBR. TALTERS: You havo heard t:o rosolution. Is there a soconr? Is thoro

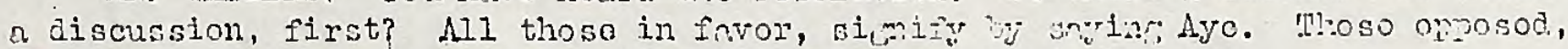
Ho. Tho Ajos havo it: Mi:o notion provails. Go nisent, ifr. Cox.

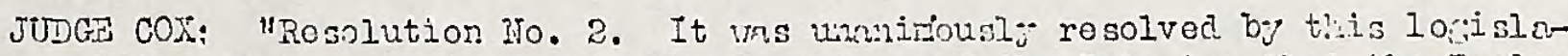

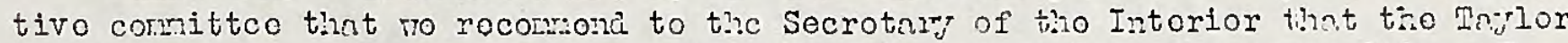

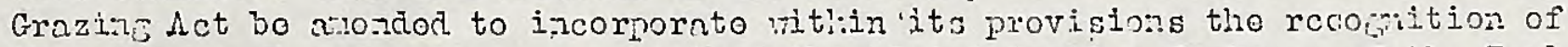
tho Advisory Boara sutaup as a part of the aninistrativo foatures of tae Darlor Grazing lav." I nove tho adoption of that rosolution.

MR. WLITIRS: Do I henr a socondr (Motion secondoa.) All t'loso in favor, soy dive. Contrar, No. The Ayos thve it. Tho motion prevnils.

JUDGS COX: "Rosolution No. 3. It was unaninously resolvod that 70 rocor:rend to tho sccratary of tho Intorior that Soction 10 of tho Tavlor Grazing Act bo so ar:endod as to provide that iastead of $50 \%$;oi: to tho soverril state tronsurors to bo oxponded as theroin provided, thet said $50 \%$ bo nddec. to t!ro $25 \%$, maline $75 \%$ in all to bo used for tho jurposos sot out in tho 1 ct, upon tho recor:mendation of tho Advisory Bonra under the diroction of tio Socrotar of tho I:tterior and on tho recorzondation of tho Ajivisory Bonri."

Just a rore in explanntion of that rosolution, bofore I :avo its acoption. It wos crlled. to the attention of rour lor;ilativo comititeo, that, $i:$ a nubor of

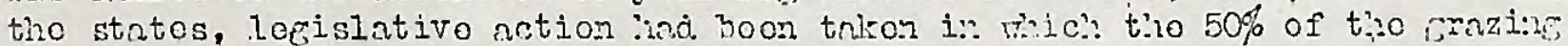
foos thet was returnce to tho states, havo boon dirortod into school func.s and into conoral country funds. Your cormittoe folt that oll of this should ;o for range iriprovonont, undor suporvision of the drvisori Bonre, and tho secretnry, na, focline that porhaps thore nny be sono diffieult; in jotting tho law

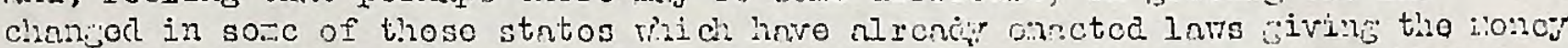

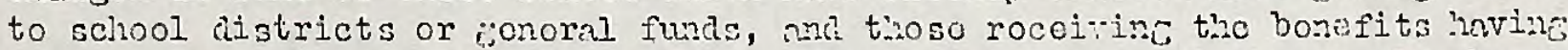

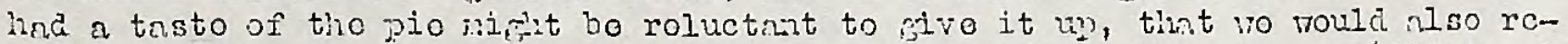
comend, in addition to t'ro proposen stato lnn, unifom stato lnn, andaitional

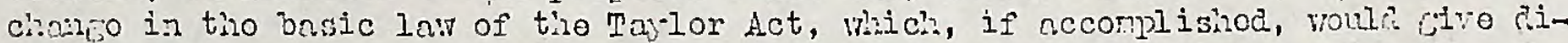
roctly, or approprinto dircctly, thut tho Socrotary and tho Advisony Bonras, 2 totnl of $75 \%$ of tllo foe to be used for rnno imrovo:iont.

Ir. Chair.nn, with that oxplanntion, I nove tho acoption of Rosolution Mo. 3.

UR. TALTERS: Is thorc a socond to tho notion? (Socondod,) Is thoro a discussion? If not, tioso in favor, sicinfo by sning $\mathrm{A}^{-0}$. ContrarJ, Iro. Tho Aycs have it; tho rotion prevnils. 
JUDGE COX: "Resolution No. 4: To comond the Socretary of tho Interior for his splondid adrinistration of the Tnylor Grazin- Act nut for his sclection of T. R. Carponter as Diroctor of Grazing ..." a nan rino, I right state, has really boen the fathor, in a lare seinse, of this particular adninistration of the Trylor Grozine, Act, who has fatherod the idon, the tionny, of locnl autonory, in tho solution of crazine problens nons the livestook ran. Fron iv obsorvation, winere i have travolod, it is ay honost juinont tiat, if we had not hed a nar of tho capebilities and the fight that hr. Carpenter lins sivon to us, that ro rould not have hind the participation in tle halding of tise grazine probloss that we now enjoy undor the advisory board set-up, nd your 10,isl'tive coraitteo, foeling tinet my, ando this conrerdation.

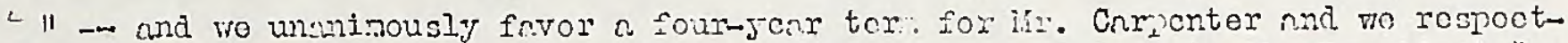
"fully roconsend that tho Socrotar male this rccomonintion to t'se Presidont."

I nove tho adoption of that resolution.

MR. FAITERS: You have heard the notion; is thero a second. (secord.) Is thore a discussion? If not, all those is frvol sifoing by sofins Ayo. Contrary, To. The Ares inve it; the notion provils uni:inouslit.

JUDG COX: "It vas unni-nously resolved by this logis]. ntive comittee that we recomond to the Socrotary of tise Inverior that section 17 of the Trivlor Grazing Act we anended to provide for a definite fom-jonr teris for the Director of Grazine; and

"Bo it further resolved, thot section 17 be mondoe to provido thet in rakinc fur ture apnointments livostock nen connected witi the Thlor Graini; Aot iron ench

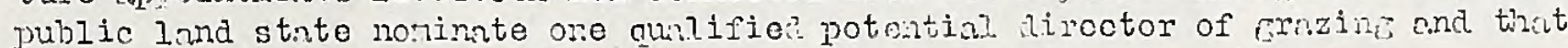
- fror these selections the Director by ajpinte?"

I nicht stato, orieflor, in explention of thrt roolution, thint it wes the

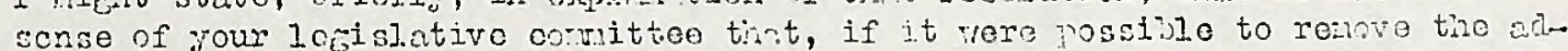
ritinistration of the livestook provlo:ss to the nxtert thint it would not bo male too mach of a political foothell, nne to tiro extont tiat re vould alvers be assured of a restern ran who is nequinter vith rester: prob?ens, nad to the further

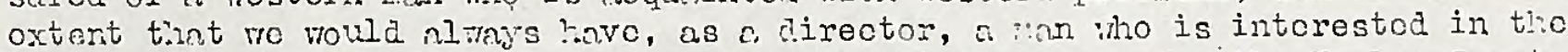
livestock probler:s of the west, a nan viho had interests un er tho Taylor Grazine Act, and a ran who is interostec in secine tho precont sot-up, wher tho Departm nont of the $I_{n}$ torior, of tis porticulal airiristrative systen! !ept in force, that ro rould achiove tilis by naxing an anundront to this law, which vould carry out this jurpose. Mr. Secreter, I novo tho acoption of that resolution.

\section{IIR. TALTERS: Is there a second?}

CAIT. B. C. MOSS'IAT, ROSWLL, N.M.: I rould like to second that notion, Mr. Socretary.

IR. WALTEZS: Is thero o discussion? If not, nll in favor, simify by snyine Ayo. Contrary, No. The Ajos have it. Tire notion provails unaninouslir.

JUDGE COX: Mr. Secret:ury, nin follow nowhers of thi's convention, that concluacs all of tic resolutions that your losisl-tive coinittee drow up to report at this convortion. There were sowe one or two direct reconnendictions nado by tinis legislativo conittee to tio Depart:.ent, on mtiers tiat they didn't fool wore of a lecislative nature. I thaile rou.

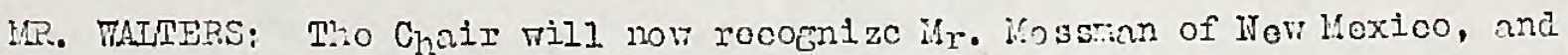
Mr. Mornrlane of Utah.

CAPM. HOSGCAT: I want to say, in openin; these briof romarks $\rightarrow$

IIR. TALTERS: Vou better como up nero, Cript, Mosenn. 


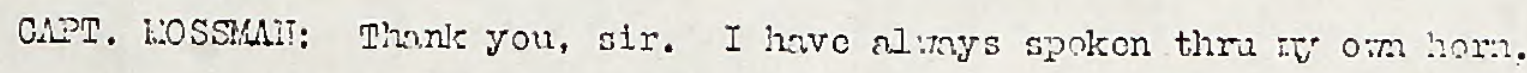

I a a frec min. I live in $I N o n$ liexico. I ar encarce in tho stopk burinose. I

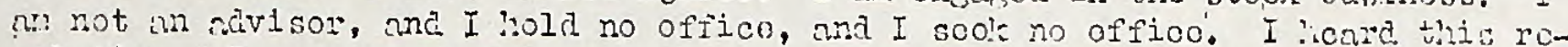
solutior. I an very glnd to seo it pess. I wisk rou could feel niout it -.. nat I think you do - - as I do, thet nevor in the history of our country hes thero beon such a dononstrition of cooperation and willikmess to coppornte :ith t:.:o bereficinries under tho Taylor Act as is shom by tho secretnry of tive Intorior, and this noblest old Roun of thor all: Secretary Trlters. It hds voci a ronderful denonstrntion, ecentlonen, of tho freodon the is accorded a pooplo, wilo nro tring to work out their om salvation undor jirisioult.

Toro wo have tho adinistration of ' 142 ailion acros, and the fortunos and volfare of zany thousnas of people, and they are invostod with tise sect:nics of

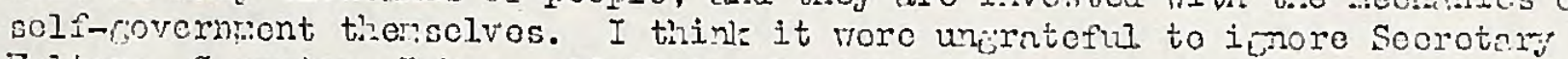
ialters, $S_{e}$ crotary Icles, and that splenild boiy of ton that have coon provided for our suidarce and direction. Thoy cnil not bo imored. Without their nssistance, there rould lave beon :any sturbles in the dors. I think that rosolution expresses our appreciation of tho whole lot.

This is a monderful county. To cormunchors in it $\rightarrow$ ro nro just cor junoliers but we aro an, after all, an I boliove thet tho peolo aro boint scle on this

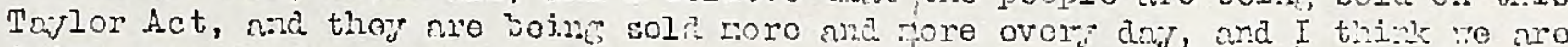
being ospecinll: sola on lif. Curpenter nas on that body of fine nen thint have beon provider for our i,uidance. Tlinill you.

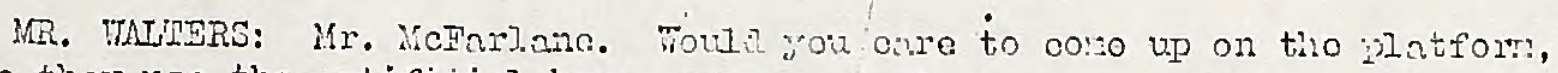
whore they use the artificial horn, od your owr?

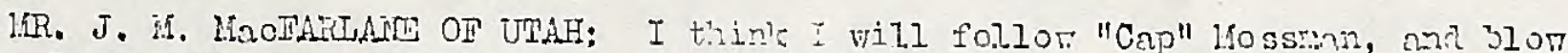
ry om horn. Mossmn ank I wore on the ranie, wero we har to malio them hoar on the other ond, before thoy had telejinnes, so ro cultivated voicos tiat onriod, and I hopo tint I con do tint trinz.

I have a resolution here that I wast to srenmit. It was givon to no by a conmit-

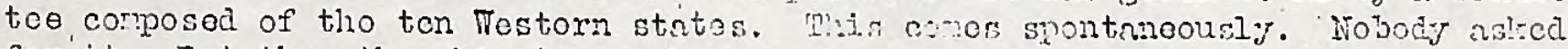
for'int. But thoy thought, inasmo!n as Jtaiz wis liost to this body, that I should prosent it. So I an goine to real this dusolution:

"Thercas, the Socretary of the Intcrior Sarold I. Io'ves has soon fit to call t?.. is tho Socond Anrunl Conforonco of tho District Auviaror Bon, fron the ton wostcin statos, to corfor vith ench othor wn: the Dopartiont on tho males and roculations coverning; tho public domin, therow insurine n greater locnl autonory; thoreforo

"Be it resolved: That wo comone tho socretnr for his spocinl intorest in acLinistration of tho Tälor Grain Act bü soncin out the First Assistant Secre-

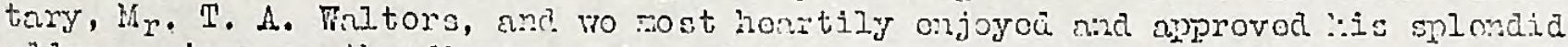

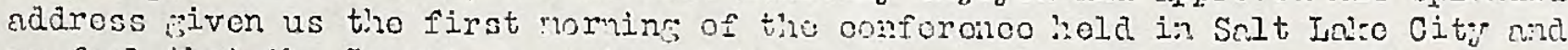
Fe foel that tho Sccrotay could not lave dono anything bottor to cencut tho woodrill of tho wosteri livostock non than to soni a man who has been born and brod in tho West hero to reprosent his at this onforence.

"Wo further corriend the socrotany on tho splondid choico ho mado in appointine Mr. F. R. Corponter as Diroctor of Grazing and ro sincerely hope that lir. Cnmonr. tor con romain witi us until this Aduinistration of the Tarlor Bill ans boen -thoroughy put on a fim foundation and porranoat por:its are issued."

Gentlesen, this ropresents the unaninsus approval of tho ton vostom states, and I zove its adoption.

VOICE: I second tho notion.

M. MacFAruARE: All in favor of this rootinn nill stand, plonso. ****** Mr. Socretary, I t'inke this is una:inous. I thinn! you. 
VICE: Will tho aithor of, the resolution just boar with no for a romont. $H_{0}$ snys that tho scrvicos of $\mathrm{ir}$. Cirpenter vo continued for four Jonrs. Wiy can't ro say just "bo continued." To don't noed to sor for any length of tinc. Why don't we say that tho sorvices of Mr. Carpontorlbe continued".

l.R. RAIRERS: I alurehond, if $M_{Y}$. Cnrpenter continuos during tho mplicntion of the Taylor Grazing Act, his lifo spar vijl be larjely in excess of that of Metlusolah. However, Mr. MacFarlnse would no kou'st jo flnd to ontertain any suisestion for altoration or zodificntion of the resolution. I vill call upon $M_{r}$. WacFnrlaise, if you vish to offor an n:ondient or mojification. I shall coll Mr. Mactarlane to the chair, bocause I feel sonctint r:odest, under the circur. stances, flnttered and yet huriliateri in a my. Mr. KacFarlane, do jou rish to malre a rotion?

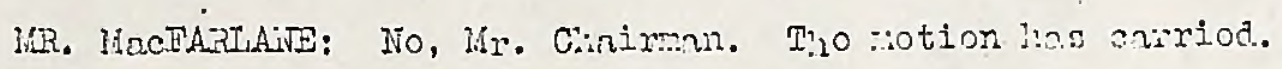

3RP. ThITERS: All right, Ho d.00s not wisil to. Is there anythins furthor to cone boforo this meeting?

IRR. TERRETr: I have a bricf an:uouncenunt to nn:e. Dolouates fron Froming and Ore on have roquested a scetins to consider locnl associntions and cooporn-

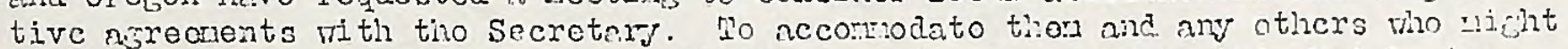
wish to attchd tho hearine, tizore sill bo a noetini at $2: 15$ in this sotol, in Roon C.38.

:IR. WAITPRS: Is thore any further business? If not, I would just like to say, beforo we present the find notion, that t?ere is noting at this ti::o of the your tint could bo more npropriate, mhich is inscriked in red uj here, tian the nor?s: "Herry Christnes". I don't care what your roli $i_{i} ;$ ous belio $i$ is or

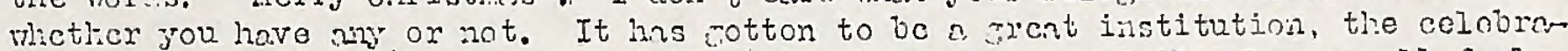
tion of Gristins. It j.s of tho henrt n... not tho hend, and it males us all feel a littlo nore kindl. that I wish you all, nul onch and evory one of you nnd rour lovod onas, a nost

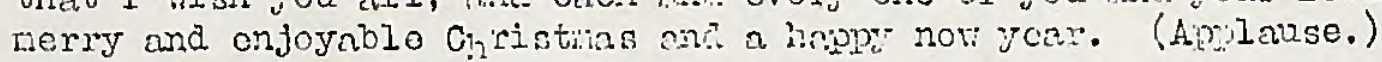

Do I hear a rotion that wo arjourn?

VOICS: I nako a zotion that wo ni journ.

IRR. FALTERS: Is it socoinec?

VOICS: Sccond tilo motion.

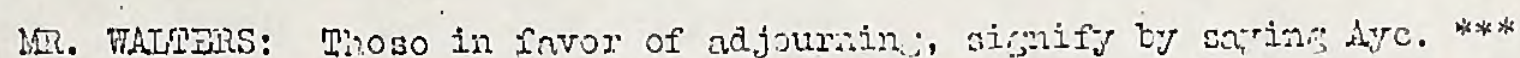
Contrary, No, *** Tho Ayes invo it. Tho notion prevnils. I thank Jou.

(Arjour:uiont, nt 12:30 PM, Dec. II, 1936.). 